UNIVERSIDADE DE SÃO PAULO

FACULDADE DE MEDICINA DE RIBEIRÃO PRETO

GISLANE LELIS VILELA DE OLIVEIRA

Análise da expressão gênica por microarrays de células-tronco hematopoéticas e mesenquimais de pacientes com esclerose múltipla 


\section{Análise da expressão gênica por microarrays de células-tronco hematopoéticas e mesenquimais de pacientes com esclerose múltipla}

Tese apresentada a Faculdade de Medicina de Ribeirão Preto da Universidade de São Paulo para obtenção do título de Doutor em Ciências.

Área de Concentração: Imunologia Básica e Aplicada

Orientador: Prof. Dr. Eduardo Antônio Donadi

Ribeirão Preto 
AUTORIZO A REPRODUÇÃO E DIVULGAÇÃO TOTAL OU PARCIAL DESTE TRABALHO, POR QUALQUER MEIO CONVENCIONAL OU ELETRÔNICO, PARA FINS DE ESTUDO E PESQUISA, DESDE QUE CITADA A FONTE.

Oliveira, Gislane Lelis Vilela de

Análise da expressão gênica por microarrays de célulastronco hematopoéticas e mesenquimais de pacientes com esclerose múltipla. Ribeirão Preto, 2013.

152 p. : il. ; $30 \mathrm{~cm}$.

Tese de Doutorado apresentada à Faculdade de Medicina de Ribeirão Preto da Universidade de São Paulo - Área de concentração: Imunologia Básica e Aplicada

Orientador: Donadi, Eduardo Antônio

1. autoimunidade. 2. esclerose múltipla. 3. células-tronco hematopoéticas. 4. células estromais mesenquimais. 5. expressão gênica diferencial. 
Esta tese recebeu fomento da Fundação de Amparo à pesquisa do Estado de São Paulo (FAPESP), processo 2008/58387-0 
FOLHA DE APROVAÇÃO

\section{GISLANE LELIS VILELA DE OLIVEIRA}

Análise da expressão gênica por microarrays de células-tronco hematopoéticas e mesenquimais de pacientes com esclerose múltipla

Tese apresentada a Faculdade de Medicina de Ribeirão Preto da Universidade de São Paulo para obtenção do título de Doutor em Ciências

Área de Concentração: Imunologia Básica e Aplicada

Aprovado em:

\section{Banca Examinadora}

Prof. Dr.

Instituição: Assinatura:

Prof. Dr.

Instituição: Assinatura:

Prof. Dr.

Instituição: Assinatura: 
Aos meus país Luiz e Sonía, com imensa gratidão e à memóría do Professor Júlio César Voltarelli 


\section{AGRADECIMENTOS:}

À Deus pela minha vida e por toda força e coragem que tem me dado em todos os momentos;

Aos meus pais, Luiz e Sonia, por terem me proporcionado condições de chegar até

aqui. À minha irmã Gisele e meu cunhado Gustavo por estarem sempre presentes. A minha prima querida Ana Carolina Costa Roma e André Luis Lourenço pela amizade e carinho. A todos os meus familiares que sempre me apoiaram incondicionalmente: Madrinha Sueli, Branca, Junior, padrinho Ademar e tio Pedro;

Aos pacientes com esclerose múltipla que confiam na equipe médica e cedem gentilmente as amostras de medula óssea para que a pesquisa possa acontecer;

Aos doadores saudáveis de medula óssea e aos doadores controles de sangue periférico que participaram deste projeto, pois sem esses esta pesquisa não seria possível;

Ao querido Prof. Dr. Júlio César Voltarelli pela oportunidade única de ter feito parte do seu grupo de pesquisa, nos ensinando o verdadeiro sentido e valor da pesquisa científica, sempre com muita humildade, persistência e irreverência;

Ao orientador Prof. Dr. Eduardo Antônio Donadi por nos ter acolhido em um momento tão delicado de nossa trajetória e por toda ajuda e correções nas etapas finais;

À minha coorientadora Profa. Dra. Kelen Cristina Ribeiro Malmegrim de Farias pela amizade, dedicação ao grupo e ajuda no decorrer desses quatro anos de doutorado;

À todos os amigos do Laboratório de Cultura Celular pela ajuda, paciência e apoio: Carolina Caliari, Juliana Ueda, Mariana Davanso, Lucas Coelho, Robson Amaral, Rafael Biaggio, Amanda Colombini, Rosane Bolzoni, Amanda Mizukami, Mario Santos Neto e Maria Izabel Martinez. Em especial aos amigos queridos Julia Teixeira Cottas de Azevedo e Kalil Alves de Lima;

À todos os amigos do Laboratório de Biologia Molecular: Aline, Tathi, Maurício, Katia, Mariana, Mayra, Virginia e Slav. Em especial à funcionária e amiga querida Evandra Strazza Rodrigues; 
Ao Prof. Dr Rodrigo Panepucci e Amélia Góes Araújo pelo auxílio com os experimentos de microarrays;

À Patrícia, Camila e Daiane do Laboratório de Citometria de Fluxo do Hemocentro pelo auxílio nos experimentos. E também à Fabiana do Laboratório de Citometria de Fluxo da Faculdade de Ciências Farmacêuticas pelo auxílio com os experimentos de CBA flex;

Ao bioinformata Daniel Guariz Ribeiro pelas análises dos microarrays;

À Profa. Dra. Fabíola Attié de Castro pela grande colaboração para a minha formação profissional;

Ao Rodrigo, Guilherme, Mônica e Marjorie da Biblioteca da Fundação Hemocentro pela imensa solicitude e cooperação de sempre;

Às tradutoras Fernanda Udinal e Alessandra Almeida pela disponibilidade sempre que solicitadas;

À Dalvinha pela amizade e pelos conselhos sempre muito sábios;

À Ana, secretária do Departamento de pós-graduação em Imunologia, pela dedicação aos alunos da imuno e presteza em todos os momentos;

À todos os professores do Programa de Pós-graduação em Imunologia Básica e Aplicada pela formação profissional incomparável que nos oferecem;

Às amigas queridas Aline Fernanda Ferreira, Alessandra de Paula Souza, Fernanda Manuela Trigo, Lucila Habbib, Livia Regatieri, Carol Raduan, Fernanda Carregaro e ao Everton Padilha, por toda amizade, força e apoio de sempre;

Ao Orgmar pela imensa ajuda e por ter me tornado uma "pessoa mais humana";

Ao assessor da FAPESP pelas avaliações e sugestões nos relatórios apresentados;

À Fundação de Amparo à Pesquisa do Estado de São Paulo (FAPESP) pelo imprescindível apoio financeiro e científico. 
"The important thing is to not stop questioning. Curiosity has its own reason for existing." 


\section{SUMÁRIO}

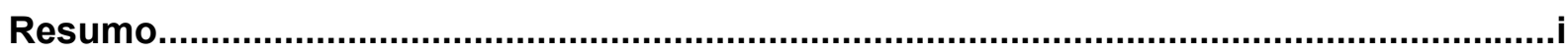

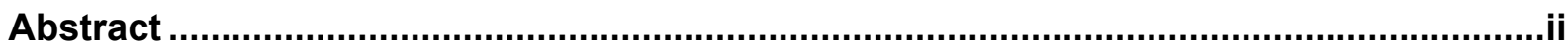

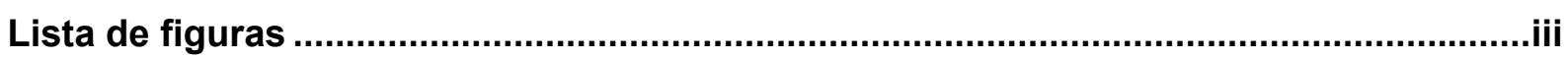

Lista de tabelas ...........................................................................................................

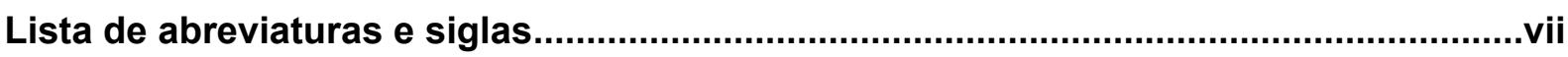

1. INTRODUÇÃO

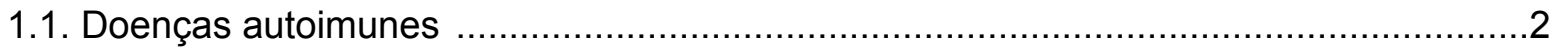

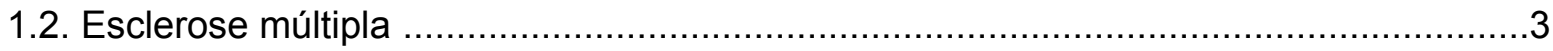

1.3. Células-tronco hematopoéticas e estromais mesenquimais .................................6

1.4. Tratamento de doenças autoimunes com células-tronco hematopoéticas e

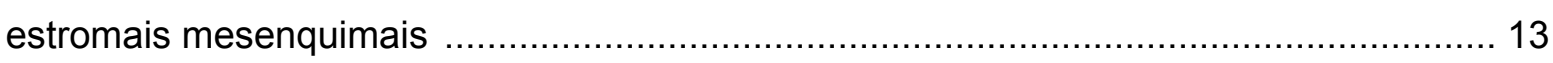

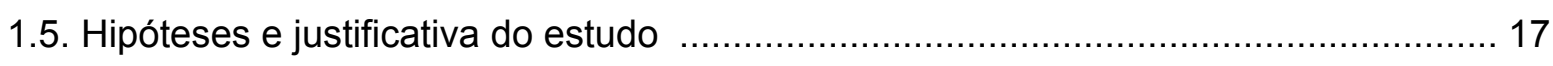

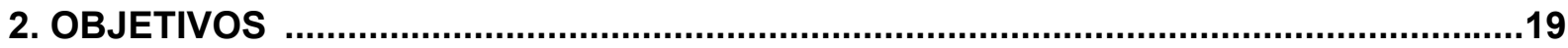

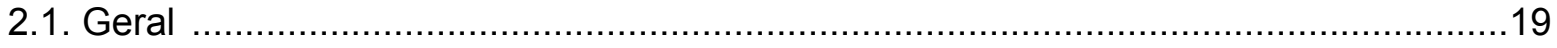

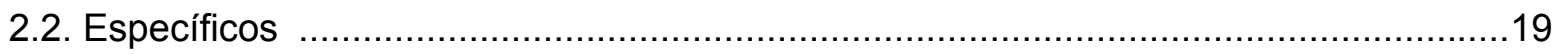

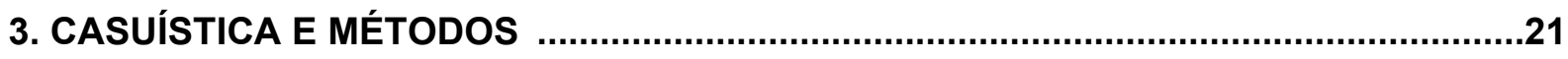

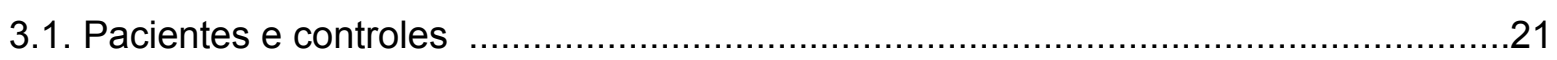

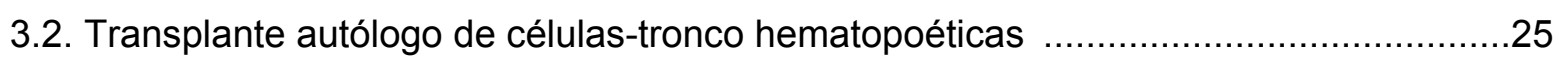

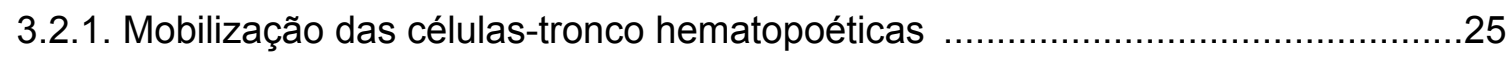

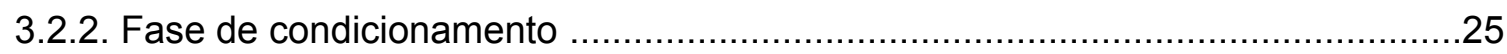

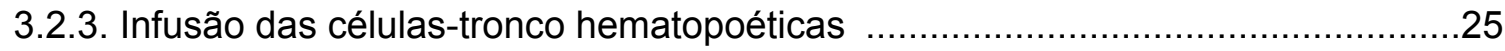

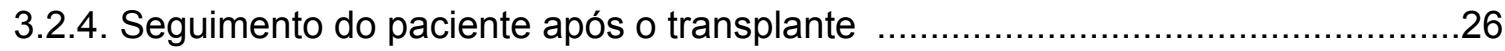

3.3. Isolamento de células mononucleares da medula óssea ......................................26

3.4. Separação imunomagnética de células-tronco hematopoéticas ..............................26

3.5. Isolamento e cultura de células estromais mesenquimais .....................................27

3.6. Caracterização imunofenotípica de células estromais mesenquimais ......................27

3.7. Diferenciação multipotencial de células estromais mesenquimais ...........................28

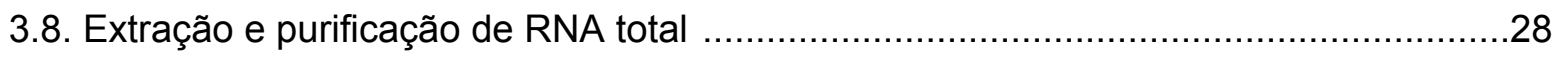

3.9. Análise da expressão gênica diferencial por microarrays .......................................30

3.10. Ensaio de cocultivo de células estromais mesenquimais e linfócitos alogênicos .......30

3.11. Quantificação de citocinas no sobrenadante dos cocultivos .................................31

3.12. Análise estatística e dos dados de microarrays ...................................................33 


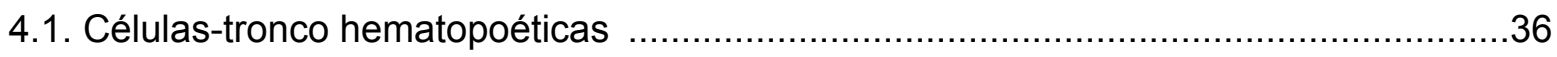

4.1.1. Análise da pureza das células-tronco hematopoéticas ...................................36

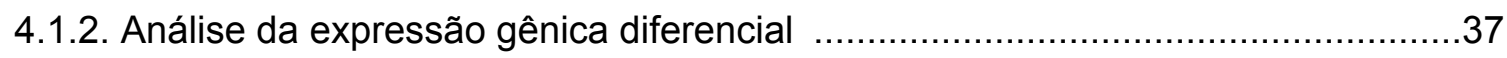

4.1.3. Enriquecimento funcional dos genes diferencialmente expressos .....................42

4.1.4. Análise de processos biológicos significantes ...............................................49

4.1.5. Análise de vias de sinalização significantes ...................................................50

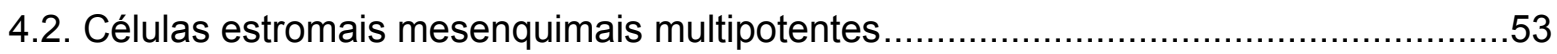

4.2.1. Caracterização morfológica, imunofenotípica e capacidade de diferenciação

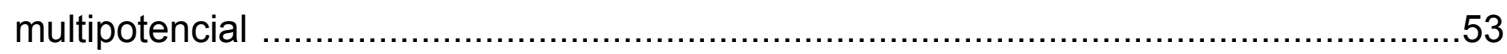

4.2.2. Análise da expressão gênica diferencial ..................................................57

4.2.3. Enriquecimento funcional dos genes diferencialmente expressos .....................63

4.2.4. Análise de processos biológicos significantes ................................................66

4.2.5. Análise de vias de sinalização significantes ..................................................69

4.2.6. Capacidade de inibição da proliferação de linfócitos alogênicos ........................70

4.2.7. Avaliação das subpopulações linfocitárias após o cocultivo com células

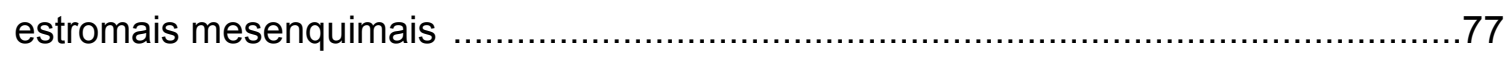

4.2.8. Perfil de citocinas no sobrenadante das coculturas ..........................................79

5. DISCUSSÃO 82

5.1. Análise da expressão gênica nas células-tronco hematopoéticas .............................82

5.2. Caracterização das células estromais mesenquimais ..........................................95

5.3. Análise da expressão gênica nas células estromais mesenquimais .........................97

5.4. Capacidade de inibição da proliferação de linfócitos alogênicos ............................102

5.5. Avaliação das subpopulações linfocitárias após o cocultivo com células estromais

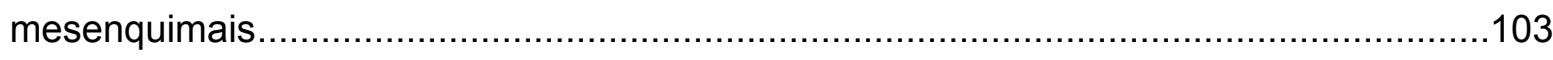

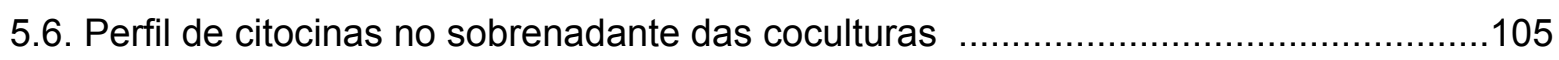

6. CONCLUSÕES 


\section{RESUMO}

OLIVEIRA, G. L. V. Análise da expressão gênica por microarrays de células-tronco hematopoéticas e mesenquimais de pacientes com esclerose múltipla. 2013. 152f. Tese de Doutorado. Faculdade de Medicina de Ribeirão Preto - Universidade de São Paulo, Ribeirão Preto, 2013.

As células-tronco hematopoéticas (CTHs) e estromais mesenquimais multipotentes (CTMs) isoladas da medula óssea vêm sendo utilizadas como fonte autóloga no tratamento de doenças autoimunes, como a esclerose múltipla (EM). As CTHs dão origem a todas as células dos sistemas hematopoético e imunológico e as CTMs possuem propriedades imunomoduladoras pela liberação de fatores solúveis e interação célula-célula. Existem trabalhos que sugerem que as doenças autoimunes sejam provenientes de defeitos intrínsecos nas células-tronco precursoras da medula óssea. Com o intuito de avaliar se as CTHs e CTMs de pacientes com EM possuem alterações intrínsecas, o objetivo geral deste trabalho foi avaliar o perfil de expressão gênica diferencial por microarrays de CTHs e CTMs de pacientes com EM, além de avaliar o perfil de expressão gênica de CTMs após o transplante autólogo de CTHs e a capacidade imunomoduladora in vitro das CTMs de pacientes. As CTHs e CTMs foram isoladas da medula óssea de pacientes com EM e doadores saudáveis, após consentimento informado. As CTHs foram isoladas por colunas imunomagnéticas e as CTMs foram isoladas por gradiente de densidade e submetidas à caracterização morfológica, imunofenotípica e capacidade de diferenciação em adipócitos e osteócitos. O RNA das CTHs e CTMs foi extraído e purificado e o perfil de expressão gênica foi avaliado por microarrays, utilizando hibridações em lâminas contendo 44.000 sondas. A capacidade imunomoduladora das CTMs de pacientes e controles foi avaliada por ensaios de cocultivo com linfócitos alogênicos e as citocinas foram quantificadas no sobrenadante por CBA flex e ELISA. Este estudo foi aprovado pelo comitê de ética do Hospital das Clínicas da Faculdade de Medicina de Ribeirão Preto. Os resultados mostraram que as CTHs de pacientes possuem perfis de expressão gênica diferentes dos controles, com 2.722 genes diferencialmente expressos, envolvidos em vias de sinalização importantes para manutenção/proliferação das CTHs e diferenciação em linhagens específicas durante a hematopoese. Dentre essas sinalizações estão incluídas as vias da apoptose, Wnt, Notch, mTOR, PI3K/Akt e Ca/NFAT, sugerindo que as CTHs de pacientes com EM possuam alterações intrínsecas que podem estar relacionadas com a patogenia da doença autoimune. As CTMs isoladas de pacientes com EM exibiram aparência senescente e reduzida expressão de marcadores imunofenotípicos. Com relação à expressão gênica, as CTMs de pacientes possuem perfil diferente das CTMs controle, sendo detectados 618 genes diferencialmente expressos, incluindo genes relacionados à sinalização FGF, HGF, sinalização de moléculas de adesão e moléculas envolvidas nos processos de imunorregulação, como IL10, IL6, TGFB1, IFNGR1, IFNGR2 e HGF. O perfil de expressão gênica das CTMs de pacientes pós-transplante assemelhou-se ao perfil das CTMs prétransplante. Ensaios de cocultivo de CTMs com linfócitos alogênicos mostraram que as CTMs de pacientes possuem capacidade antiproliferativa reduzida em relação às CTMs controle, e ainda, secreção reduzida de TGF- $\beta$ e IL-10 no sobrenadante das coculturas. Esses dados sugerem que as CTMs isoladas de pacientes com EM possuam alterações fenotípicas, transcricionais e funcionais. Embasados nesses achados, concluímos que as CTHs e as CTMs de pacientes com EM possuem alterações intrínsecas que podem estar relacionadas com a patogenia da doença. Uma vez que as CTMs sejam células com grande potencial terapêutico para controle da EM em pacientes refratários aos tratamentos convencionais, as alterações encontradas sugerem que CTMs de doadores saudáveis sejam mais adequadas em aplicações clínicas.

Palavras-chave: doenças autoimunes, esclerose múltipla, células-tronco hematopoéticas, células estromais mesenquimais multipotentes, expressão gênica diferencial 


\begin{abstract}
OLIVEIRA, G. L. V. Gene expression profiles of hematopoietic stem cells and mesenchymal stromal cells obtained from multiple sclerosis patients and detected by microarrays. 2013. 152f. Thesis (PhD). School of Medicine of Ribeirão Preto - University of São Paulo, Ribeirão Preto, Brazil, 2013.
\end{abstract}

Bone marrow hematopoietic stem cells (HSCs) and mesenchymal stromal cells (MSCs) have been used as an autologous source to treat autoimmune diseases, such as multiple sclerosis (MS). HSC give rise to all hematopoietic and immune system cells, and MSCs exhibit immunomodulatory properties by releasing soluble factors and by cell-cell interactions. Evidence indicates that bone marrow stem cells obtained from patients with autoimmune diseases may present intrinsic defects. To assess whether or not HSC and MSC of MS patients have intrinsic defects, the main objective of this study was to evaluate the differential gene expression profiles of HSC and MSC from MS patients before and after autologous HSC transplantation, and additionally, to evaluate the in vitro immunomodulatory ability of patient MSCs. Bone marrow HSC and MSCs were isolated from MS patients and healthy donors. HSCs were isolated by immunomagnetic columns and MSCs were isolated by gradient density and cultured until the third passage. MSCs were characterized according to morphology, immunophenotypic markers and cell differentiation into adipocytes and osteocytes. HSC and MSCs mRNAs were extracted, purified, and the gene expression profile was evaluated by microarray hybridizations, using a platform containing 44.000 probes. The immunomodulatory activity of patient and control MSCs was assessed by coculture assays with allogeneic lymphocytes. Cytokines were quantified in coculture supernatants by ELISA and CBA flex. This study was approved by the Ethics Committee of the University Hospital of the School of Medicine of Ribeirão Preto. The results showed that the patient HSCs exhibited a distinctive gene expression profile when compared to healthy HSCs, yielding 2.722 differentially expressed genes, involved in essential HSC signaling pathways for maintenance, proliferation and differentiation into specific lineages during hematopoiesis. Among these signaling pathways were included, apoptosis, Wnt, Notch, mTOR, PI3K/Akt and Ca/NFAT, suggesting that patient HSCs have significant intrinsic transcriptional alterations that may be associated with MS pathogenesis. Regarding MSCs isolated from MS patients, they exhibited senescence appearance, decreased expression of immunophenotypic markers, and also exhibited a distinctive gene expression profile in relation to healthy MSCs, yielding 618 genes differentially expressed genes, included in FGF and HGF signaling pathways, adhesion molecules, and genes involved in immunoregulation processes, such as IL-10, IL-6, TGFB1, IFNGR1, IFNGR2 and HGF. Coculture assays of control or patient MSCs with allogeneic lymphocytes showed that patient cells exhibited reduced antiproliferative activity as compared with controls, and also exhibited reduced secretion of TGF- $\beta$ and IL-10 cytokines in coculture supernatants. These data suggest that MSCs isolated from MS patients have phenotypic, functional and transcriptional defects, highlighting genes related to MSC maintenance, adhesion and immunomodulatory effects. According to these results, we concluded that patient HSCs and MSCs have intrinsic defects that may be associated with the disease per se. Considering that MSCs exhibit great therapeutic potential to control MS patients refractory to conventional treatment, the major MSCs alterations observed in this study indicate that healthy MSCs may be more suitable for MS cell therapy.

Keywors: autoimmune diseases, multiple sclerosis, hematopoietic stem cells, multipotent mesenchymal stromal cells, differential gene expression profile. 


\section{LISTA DE FIGURAS}

FIGURA 1. Análise imunofenotípica de células-tronco hematopoéticas purificadas da medula óssea de um doador saudável, mostrando $97,44 \%$ de pureza de células CD $34^{+}$.

FIGURA 2. MA plots representando os dados de intensidade de fluorescência dos microarrays.

FIGURA 3. Dispersão espontânea das amostras de células-tronco hematopoéticas hibridadas nos microarrays por meio da análise de componente principal.

FIGURA 4. Normalização dos dados de expressão gênica das células-tronco hematopoéticas isoladas de doadores saudáveis de medula óssea e de pacientes com esclerose múltipla.

FIGURA 5. Clusterização hierárquica euclideana simples dos dados de expressão gênica das célulastronco hematopoéticas isoladas de doadores saudáveis de medula óssea e de pacientes com esclerose múltipla.

FIGURA 6. Grupo de genes diferencialmente expressos nas células-tronco hematopoéticas isoladas de pacientes com esclerose múltipla em comparação às células controle.

FIGURA 7. Clusterização supervisionada de sondas com maior variância de expressão entre as células-tronco hematopoéticas isoladas de indivíduos saudáveis e de pacientes com esclerose múltipla.

FIGURA 8. Classificação dos genes reprimidos nas células-tronco hematopoéticas de pacientes com esclerose múltipla em funções biológicas.

FIGURA 9. Classificação dos genes reprimidos nas células-tronco hematopoéticas de pacientes com esclerose múltipla em vias de sinalização.

FIGURA 10. Classificação dos genes induzidos nas células-tronco hematopoéticas de pacientes com esclerose múltipla em funções biológicas.

FIGURA 11. Classificação dos genes induzidos nas células-tronco hematopoéticas de pacientes com esclerose múltipla em vias de sinalização.

FIGURA 12. Heatmap contendo genes induzidos e reprimidos, pertencentes às vias de sinalização (A) da apoptose e (B) Notch, nas células-tronco hematopoéticas de pacientes com esclerose múltipla..

FIGURA 13. Heatmap contendo genes induzidos e reprimidos, pertencentes às vias de sinalização (A) Wnt e (B) mTOR, nas células-tronco hematopoéticas de pacientes com esclerose múltipla. . ..... 48

FIGURA 14. Heatmaps gerados pelo Gene Set Enrichment Analysis contendo genes enriquecidos dentro dos processos biológicos significantes quando comparamos as células-tronco hematopoéticas de pacientes com esclerose múltipla às células controle.

FIGURA 15. Via de sinalização PI3K/AKT gerada pelo software Ingenuity Pathway Analysis quando comparamos as células-tronco hematopoéticas de pacientes com esclerose múltipla às células controle. 
FIGURA 16. Via de sinalização mTOR gerada pelo software Ingenuity Pathway Analysis quando comparamos as células-tronco hematopoéticas de pacientes com esclerose múltipla às células controle.

FIGURA 17. Via de sinalização da apoptose gerada pelo software Ingenuity Pathway Analysis quando comparamos as células-tronco hematopoéticas de pacientes com esclerose múltipla à células controle.

FIGURA 18. Caracterização morfológica de células estromais mesenquimais de indivíduos saudáveis e de pacientes com esclerose múltipla. 54

FIGURA 19. Caracterização imunofenotípica de células estromais mesenquimais isoladas de doador saudável de medula óssea.

FIGURA 20. Porcentagem de células positivas para os marcadores imunofenotípicos característicos expressos nas células mesenquimais estromais de indivíduos saudáveis e de pacientes com esclerose múltipla pré- e pós-transplante.

FIGURA 21. Diferenciação de células estromais mesenquimais de indivíduos saudáveis e pacientes com esclerose múltipla em adipócitos e osteócitos.

FIGURA 22. MA plots representando os dados de intensidade de fluorescência dos microarrays. ... 58

FIGURA 23. Dispersão espontânea das amostras de células estromais mesenquimais hibridadas nos microarrays por meio da análise de componente principal.

FIGURA 24. Normalização dos dados de expressão gênica das células estromais mesenquimais isoladas de doadores saudáveis e de pacientes com esclerose múltipla nos períodos pré- e póstransplante.

FIGURA 25. Clusterização hierárquica euclideana simples dos dados de expressão gênica das células estromais mesenquimais isoladas de doadores saudáveis e de pacientes com esclerose múltipla nos períodos pré- e pós-transplante.

FIGURA 26. Grupo de genes diferencialmente expressos nas células estromais mesenquimais (A) de pacientes com esclerose múltipla em comparação às células controle e, $(B)$ nas células estromais mesenquimais de pacientes pós-TACTH em comparação ao pré-transplante.

FIGURA 27: Clusterização hierárquica supervisionada das 100 sondas com maior variância de expressão entre as células estromais mesenquimais isoladas de doadores saudáveis e de pacientes com esclerose múltipla.

FIGURA 28. Classificação dos genes induzidos nas células estromais mesenquimais de pacientes com esclerose múltipla em funções biológicas.

FIGURA 29. Classificação dos genes reprimidos nas células estromais mesenquimais de pacientes com esclerose múltipla em funções biológicas.

FIGURA 30. Classificação dos genes induzidos nas células estromais mesenquimais de pacientes com esclerose múltipla pós-transplante em funções biológicas. 
FIGURA 31. Heatmaps gerados pelo Gene Set Enrichment Analysis contendo genes enriquecidos dentro dos processos biológicos significantes quando comparamos as células estromais mesenquimais de pacientes com esclerose múltipla às células controle. 68

FIGURA 32. Via de sinalização do FGF gerada pelo Software Ingenuity Pathway Analysis quando comparamos as células estromais mesenquimais isoladas de pacientes com esclerose múltipla às células controle. 69

FIGURA 33. Via de sinalização do HGF gerada pelo Software Ingenuity Pathway Analysis quando comparamos as células estromais mesenquimais isoladas de pacientes com esclerose múltipla às células controle. 70

FIGURA 34. Figura 34: Efeito inibitório de células estromais mesenquimais isoladas de doadores saudáveis de medula óssea na proliferação de linfócitos alogênicos. 71

FIGURA 35. Porcentagens de proliferação e inibição da proliferação de linfócitos alogênicos cocultivados com células estromais mesenquimais isoladas de dezesseis doadores saudáveis de medula óssea. 72

FIGURA 36. Porcentagens de proliferação e inibição da proliferação de linfócitos alogênicos cocultivados com células estromais mesenquimais isoladas da medula óssea de dez pacientes com esclerose múltipla do período pré-transplante. 74

FIGURA 37. Porcentagens de proliferação e inibição da proliferação de linfócitos alogênicos cocultivados com células estromais mesenquimais isoladas da medula óssea de nove pacientes com esclerose múltipla no período pós-transplante. 75

FIGURA 38. Comparação do efeito antiproliferativo de células estromais mesenquimais isoladas de doadores saudáveis e de pacientes com esclerose múltipla nos períodos pré- e pós-transplante. .... 76

FIGURA 39. Comparação da capacidade de inibição da proliferação de linfócitos alogênicos após cocultivo com células estromais mesenquimais isoladas de doadores saudáveis e de pacientes com esclerose múltipla dos períodos pré- e pós-transplante.

FIGURAS 40. Concentração de citocinas pró- e anti-inflamatórias, HGF e da quimiocina CXCL-10 no sobrenadante das coculturas de linfócitos alogênicos com células estromais mesenquimais isoladas de doadores saudáveis e de pacientes com esclerose múltipla pré- e pós-transplante. 


\section{LISTA DE TABELAS}

TABELA 1. Características clínico-demográficas dos pacientes com esclerose múltipla (EM) no período anterior ao transplante autólogo de células tronco hemtopoéticas (TACTH).

TABELA 2. Avaliação neurológica e resposta clínica dos pacientes com esclerose múltipla (EM) após o transplante autólogo de células-tronco hematopoéticas (TACTH).

TABELA 3. Conjunto de processos biológicos significantes gerados pelo Gene Set Enrichment Analysis quando comparamos as células-tronco hematopoéticas de pacientes com esclerose múltipla às células controle.

TABELA 4. Conjunto de processos biológicos significantes gerados pelo Gene Set Enrichment Analysis quando comparamos as células estromais mesenquimais de pacientes com esclerose múltipla às células controle.

TABELA 5. Porcentagens de subpopulações linfocitárias recuperadas após o cocultivo de linfócitos alogênicos e células estromais mesenquimais isoladas de doadores saudáveis (controles) e de pacientes pré- e pós-transplante. 


\section{LISTA DE ABREVIATURAS E SIGLAS}

ADAM10 - do inglês "ADAM metallopeptidase domain 10"

ADAM15 - do inglês "ADAM metallopeptidase domain 15"

ADAM17 - do inglês "ADAM metallopeptidase domain 17"

ADAM21 - do inglês "ADAM metallopeptidase domain 21"

ADAM28 - do inglês "ADAM metallopeptidase domain 28"

ADAMTS13 - do inglês "ADAM metallopeptidase with thrombospondin type 1 motif, 13"

ADAMTS3 - do inglês "ADAM metallopeptidase with thrombospondin type 1 motif, 3"

ADAMTS4 - do inglês "ADAM metallopeptidase with thrombospondin type 1 motif, 4"

ADAMTS7 - do inglês "ADAM metallopeptidase with thrombospondin type 1 motif, 7 "

ADAMTSL4 - do inglês "ADAMTS-like 4"

AGRN - do inglês "agrin"

AKT1 - do inglês " $v$-akt murine thymoma viral oncogene homolog 1"

AKT2 - do inglês " $v$-akt murine thymoma viral oncogene homolog 2"

ALCAM - do inglês "activated leukocyte cell adhesion molecule"

AMHR2 - do inglês "anti-Mullerian hormone receptor, type II"

ANGPT1 - do inglês "angiopoietin 1"

APC2 - do inglês "adenomatosis polyposis coli 2"

APH1A - do inglês "anterior pharynx defective 1 homolog A"

BAD - do inglês "BCL2-associated agonist of cell death"

$\mathrm{BAX}$ - do inglês "BCL2-associated $X$ protein"

BCL2L1 - do inglês "BCL2-like 1"

BDNF - do inglês "brain-derived neurotrophic factor"

BID - do inglês "BH3 interacting domain death agonist"

BIRC2 - do inglês "baculoviral IAP repeat containing 2"

BMP1 - do inglês "bone morphogenetic protein 1"

BTLA - do inglês " $B$ and T lymphocyte associated"

C5 - do inglês "complement component 5"

CAB39 - do inglês "calcium binding protein 39"

CAPN1 - do inglês "calpain 1, (mu/l) large subunit"

CASP3 - do inglês "caspase 3, apoptosis-related cysteine peptidase"

CASP7 - do inglês "caspase 7, apoptosis-related cysteine peptidase"

CASP8 - do inglês "caspase 8, apoptosis-related cysteine peptidase"

CCL15 - do inglês "chemokine (C-C motif) ligand 15"

CCL3L3 - do inglês "chemokine (C-C motif) ligand 3-like 3"

CCL5 - do inglês "chemokine (C-C motif) ligand 5"

CCL7 - do inglês "chemokine (C-C motif) ligand 7 "

CCND1 - do inglês "cyclin D1"

CCND2 - do inglês "cyclin D2" 
CCND3 - do inglês "cyclin D3"

CCR5 - do inglês "chemokine (C-C motif) receptor 5"

CCR7 - do inglês "chemokine (C-C motif) receptor 7 "

CCRL2 - do inglês "chemokine (C-C motif) receptor-like 2"

CD59 - do inglês "CD59 molecule, complement regulatory protein"

CDH23 - do inglês "cadherin-related 23"

$\mathrm{CDH} 24$ - do inglês "cadherin 24, type 2"

$\mathrm{CDH} 7$ - do inglês "cadherin 7, type 2"

CDH8 - do inglês "cadherin 8, type 2"

CDX2 - do inglês "caudal type homeobox 2"

CHP - do inglês "calcineurin-like EF hand protein 1"

CIR1 - do inglês "corepressor interacting with RBPJ, 1"

CKLF - do inglês "chemokine-like factor"

COL18A1 - do inglês "collagen, type XVIII, alpha 1"

COL20A1 - do inglês "collagen, type XX, alpha 1"

COL3A1 - do inglês "collagen, type III, alpha 1"

COL7A1 - do inglês "collagen, type VII, alpha 1"

CREB5 - do inglês "CAMP responsive element binding protein 5"

CREBBP - do inglês "CREB binding protein"

CSF1 - do inglês "colony stimulating factor 1"

CSF2RA - do inglês "colony stimulating factor 2 receptor, alpha, low-affinity"

CSNK1A1 - do inglês "casein kinase 1, alpha 1"

CSNK1A1L - do inglês "casein kinase 1, alpha 1-like"

CSNK1E - do inglês "casein kinase 1, epsilon"

CSNK2A1 - do inglês "casein kinase 2, alpha 1 polypeptide"

CSNK2A2 - do inglês "casein kinase 2, alpha prime polypeptide"

CSNK2B - do inglês "casein kinase 2, beta polypeptide"

CTBP1 - do inglês "C-terminal binding protein 1"

CTBP2 - do inglês " $C$-terminal binding protein 2"

CTGF - do inglês "connective tissue growth factor"

CTLA-4 - do inglês "citotoxic T lymphocyte-associated molecule-4"

CX3CR1 - do inglês "chemokine (C-X3-C motif) receptor 1"

CXADR - do inglês "coxsackie virus and adenovirus receptor"

CXCL12 - do inglês "chemokine (C-X-C motif) ligand 12"

CXCL5 - do inglês "chemokine (C-X-C motif) ligand 5"

CXCR2 - do inglês "chemokine (C-X-C motif) receptor 2"

CXCR3 - do inglês "chemokine (C-X-C motif) receptor 3"

CX3CR1 - do inglês "chemokine (C-X3-C motif) receptor 1"

DAAM1 - do inglês "dishevelled associated activator of morphogenesis 1"

DDIT4 - do inglês "DNA-damage-inducible transcript 4" 
DDR2 - do inglês "discoidin domain receptor tyrosine kinase 2"

DIABLO - do inglês "direct IAP-binding protein with low pl"

DISC - do inglês "death-inducing signaling complex"

DFFA - do inglês "DNA fragmentation factor, $45 \mathrm{kDa}$, alpha polypeptide"

DTX2 - do inglês "deltex homolog 2" (Drosophila)

DVL3 - do inglês "dishevelled, dsh homolog 3" (Drosophila)

E2F4 - do inglês "E2F transcription factor 4, p107/p130-binding"

EIF4B - do inglês "eukaryotic translation initiation factor 4B"

EIF4E - do inglês "eukaryotic translation initiation factor 4E"

ELF1 - do inglês "E74-like factor 1 (ets domain transcription factor)"

ELISA - do inglês "enzyme-linked immunosorbent assay"

ELK1 - do inglês "ELK1, member of ETS oncogene family"

ENDOG - do inglês "endonuclease G"

EP300 - do inglês "E1A binding protein p300"

EPAS1 - do inglês "endothelial PAS domain protein 1"

EPHA1 - do inglês "EPH receptor $A 1$ "

EPHB4 - do inglês "EPH receptor B4"

ESAM - do inglês "endothelial cell adhesion molecule"

ETV1 - do inglês "ets variant 1"

FADD - do inglês "Fas (TNFRSF6)-associated via death domain"

FBXW11 - do inglês "F-box and WD repeat domain containing 11"

FOSL1 - do inglês "FOS-like antigen 1"

FOXE1 - do inglês "forkhead box E1 (thyroid transcription factor 2)"

FOXI1 - do inglês "forkhead box I1"

FOXO4 - do inglês "forkhead box O4"

FRAT1 - do inglês "frequently rearranged in advanced T-cell lymphomas"

FRAT2 - do inglês "frequently rearranged in advanced T-cell lymphomas 2"

FUBP1 - do inglês "far upstream element (FUSE) binding protein 1"

FZD2 - do inglês "frizzled family receptor 2"

FZD5 - do inglês "frizzled family receptor 5"

FZD9 - do inglês "frizzled family receptor 9"

GAS6 - do inglês "growth arrest-specific 6"

GATA1 - do inglês "GATA binding protein 1 (globin transcription factor 1)"

GDF11 - do inglês "growth differentiation factor 11"

GDF15 - do inglês "growth differentiation factor 15"

GTF2H4 - do inglês "general transcription factor IIH, polypeptide 4"

HAND1 - do inglês "heart and neural crest derivatives expressed 1"

HES5 - do inglês "hairy and enhancer of split 5"

HES6 - do inglês "hairy and enhancer of split 6"

HIF1A - do inglês "hypoxia inducible factor 1, alpha subunit (basic helix-loop-helix transcription factor)" 
HNF1B - do inglês "HNF1 homeobox B"

HSF2 - do inglês "heat shock transcription factor 2"

IGF1 - do inglês "insulin-like growth factor 1 (somatomedin C)"

IGF2 - do inglês "insulin-like growth factor 2 (somatomedin A)"

IGSF11 - do inglês "immunoglobulin superfamily, member 11"

IKBKG - do inglês "inhibitor of kappa light polypeptide gene enhancer in B-cells, kinase gamma"

IKZF4 - do inglês "IKAROS family zinc finger 4 (Eos)"

IL10RA - do inglês "interleukin 10 receptor, alpha"

IL12RB1 - do inglês "interleukin 12 receptor, beta 1"

IL13RA1 - do inglês "interleukin 13 receptor, alpha 1"

IL15RA - do inglês "interleukin 15 receptor, alpha"

IL17RD - do inglês "interleukin 17 receptor D"

IL17RE - do inglês "interleukin 17 receptor E"

IL1F6 - do inglês "interleukin 1 family, member 6"

IL1RAP - do inglês "interleukin 1 receptor accessory protein"

IL3RA - do inglês "interleukin 3 receptor, alpha" (low affinity)

IRAK1 - do inglês "interleukin-1 receptor-associated kinase 1"

IRAK3 - do inglês "interleukin-1 receptor-associated kinase 3"

IRAK4 - do inglês "interleukin-1 receptor-associated kinase 4"

IRF9 - do inglês "interferon regulatory factor 9"

ITGA10 - do inglês "integrin, alpha 10"

ITGA2B - do inglês "integrin, alpha $2 b$ (platelet glycoprotein Ilb of Illb/Illa complex, antigen CD41)"

ITGA6 - do inglês "integrin, alpha 6"

ITGA9 - do inglês "integrin, alpha 9"

ITGAL - do inglês "integrin, alpha L (antigen CD11A (p180), lymphocyte function-associated antigen 1;

alpha polypeptide)"

ITGAX - do inglês "integrin, alpha X (complement component 3 receptor 4 subunit)"

ITGB3 - do inglês "integrin, beta 3 (platelet glycoprotein IIla, antigen CD61)"

ITGB7 - do inglês "integrin, beta 7"

JUN - do inglês "jun proto-oncogene"

KLF1 - do inglês "Kruppel-like factor 1 (erythroid)"

LAMC3 - do inglês "laminin, gamma 3"

LGALS1 - do inglês "lectin, galactoside-binding, soluble, 1"

LTA - do inglês "lymphotoxin alpha (TNF superfamily, member 1)"

LZTS1 - do inglês "leucine zipper, putative tumor suppressor 1"

MAP3K7 - do inglês "mitogen-activated protein kinase kinase kinase 7"

MAPK3 - do inglês "mitogen-activated protein kinase 3"

MBD1 - do inglês "methyl-CpG binding domain protein 1"

MFNG - do inglês "MFNG O-fucosylpeptide 3-beta-N-acetylglucosaminyltransferase"

MLST8 - do inglês "MTOR associated protein, LST8 homolog" 
MORF4 - do inglês "mortality factor 4"

MST1R - do inglês "macrophage stimulating 1 receptor (c-met-related tyrosine kinase)"

MYBL2 - do inglês "v-myb myeloblastosis viral oncogene homolog (avian)-like 2"

MYD88 - do inglês "myeloid differentiation primary response 88"

MYEF2 - do inglês "myelin expression factor 2"

MYOG - do inglês "myogenin (myogenic factor 4)"

NFAT5 - do inglês "nuclear factor of activated T-cells 5, tonicity-responsive"

NFATC2 - do inglês "nuclear factor of activated T-cells, cytoplasmic, calcineurin-dependent 2"

NFE2L2 - do inglês "nuclear factor (erythroid-derived 2)-like 2"

NFIC - do inglês "nuclear factor I/C (CCAAT-binding transcription factor)"

NFIX - do inglês "nuclear factor I/X (CCAAT-binding transcription factor)"

NFYB - do inglês "nuclear transcription factor $Y$, beta"

NPAS1 - do inglês "neuronal PAS domain protein 1"

NR3C1 - do inglês "nuclear receptor subfamily 3, group C, member 1 (glucocorticoid receptor)"

NR5A2 - do inglês "nuclear receptor subfamily 5, group A, member 2"

NRG4 - do inglês "neuregulin 4"

NTN3 - do inglês "netrin 3"

NTRK1 - do inglês "neurotrophic tyrosine kinase, receptor, type 1"

PGF - do inglês "placental growth factor"

PHTF1 - do inglês "putative homeodomain transcription factor 1"

PIK3CA - do inglês "phosphatidylinositol-4,5-bisphosphate 3-kinase, catalytic subunit alpha"

PIK3CD - do inglês "phosphatidylinositol-4,5-bisphosphate 3-kinase, catalytic subunit delta"

PIK3R1 - do inglês "phosphoinositide-3-kinase, regulatory subunit 1 (alpha)"

PIK3R2 - do inglês "phosphoinositide-3-kinase, regulatory subunit 2 (beta)"

PIK3R5 - do inglês "phosphoinositide-3-kinase, regulatory subunit 5"

PLCB3 - do inglês "phospholipase C, beta 3 (phosphatidylinositol-specific)"

PLCB4 - do inglês "phospholipase $C$, beta 4"

PODXL2 - do inglês "podocalyxin-like 2"

POU2F1 - do inglês "POU class 2 homeobox 1"

POU4F2 - do inglês "POU class 4 homeobox 2"

PPP2CA - do inglês "protein phosphatase 2, catalytic subunit, alpha isozyme"

PPP2R5B - do inglês "protein phosphatase 2, regulatory subunit $B$, beta"

PPP2R5C - do inglês "protein phosphatase 2, regulatory subunit B', gamma"

PPP3CC - do inglês "protein phosphatase 3, catalytic subunit, gamma isozyme"

PPP3R1 - do inglês "protein phosphatase 3, regulatory subunit $B$, alpha"

PRKAA1 - do inglês "protein kinase, AMP-activated, alpha 1 catalytic subunit"

PRKACA - do inglês "protein kinase, cAMP-dependent, catalytic, alpha"

PRKACB - do inglês "protein kinase, cAMP-dependent, catalytic, beta"

PRKAR1B - do inglês "protein kinase, cAMP-dependent, regulatory, type I, beta"

PRKAR2B - do inglês "protein kinase, cAMP-dependent, regulatory, type II, beta" 
PRKX - do inglês "protein kinase, $X$-linked"

PSEN2 - do inglês "presenilin 2 (Alzheimer disease 4)"

PSENEN - do inglês "presenilin enhancer 2 homolog"

PTCRA - do inglês "pre T-cell antigen receptor alpha"

PVR - do inglês "poliovirus receptor"

PVRL1 - do inglês "poliovirus receptor-related 1 (herpesvirus entry mediator C)"

PVRL2 - do inglês "poliovirus receptor-related 2 (herpesvirus entry mediator B)"

RAC3 - do inglês "ras-related C3 botulinum toxin substrate 3 (rho family, small GTP binding protein

Rac3)"

RBP5 - do inglês "retinol binding protein 5, cellular"

RBPJ - do inglês "recombination signal binding protein for immunoglobulin kappa J region"

RELA - do inglês " $v$-rel reticuloendotheliosis viral oncogene homolog A (avian)"

RFNG - do inglês "RFNG O-fucosylpeptide 3-beta-N-acetylglucosaminyltransferase"

RICTOR - do inglês "RPTOR independent companion of MTOR, complex 2"

ROCK1 - do inglês "Rho-associated, coiled-coil containing protein kinase 1"

ROCK2 - do inglês "Rho-associated, coiled-coil containing protein kinase 2"

RPS6KA1 - do inglês "ribosomal protein S6 kinase, 90kDa, polypeptide 1"

RPS6KA3 - do inglês "ribosomal protein S6 kinase, 90kDa, polypeptide 3"

RPS6KB1 - do inglês "ribosomal protein S6 kinase, 70kDa, polypeptide 1"

SCAND1 - do inglês "SCAN domain containing 1"

SELPLG - do inglês "selectin P ligand"

SENP2 - do inglês "SUMO1/sentrin/SMT3 specific peptidase 2"

SIAH1 - do inglês "siah E3 ubiquitin protein ligase 1"

SIGIRR - do inglês "single immunoglobulin and toll-interleukin 1 receptor (TIR) domain"

SIGLEC5 - do inglês "sialic acid binding lg-like lectin 5"

SIGLEC9 - do inglês "sialic acid binding Ig-like lectin 9"

SKP1 - do inglês "S-phase kinase-associated protein 1"

SLC2A4RG - do inglês "SLC2A4 regulator"

SMAD2 - do inglês "SMAD family member 2"

SMAD4 - do inglês "SMAD family member 4"

SMARCA4 - do inglês "SWI/SNF related, matrix associated, actin dependent regulator of chromatin, subfamily a, member 4"

SNAPC2 - do inglês "small nuclear RNA activating complex, polypeptide 2"

SNW1 - do inglês "SNW domain containing 1"

SOX4 - do inglês "SRY (sex determining region Y)-box 4"

SP140 - do inglês "SP140 nuclear body protein"

SREBF1 - do inglês "sterol regulatory element binding transcription factor 1"

STAT4 - do inglês "signal transducer and activator of transcription 4"

STAT5A - do inglês "signal transducer and activator of transcription 5A"

STAT5B - do inglês "signal transducer and activator of transcription 5B" 
STK11 - do inglês "serine/threonine kinase 11"

TCF19 - do inglês "transcription factor 19"

TCF25 - do inglês "transcription factor 25 (basic helix-loop-helix)"

TCF4 - do inglês "transcription factor 4"

TFAM - do inglês "transcription factor A, mitochondrial"

TGFBR1 - do inglês "transforming growth factor, beta receptor 1"

TGIF1 - do inglês "TGFB-induced factor homeobox 1"

TGM2 - do inglês "transglutaminase 2 (C polypeptide, protein-glutamine-gamma-glutamyltransferase)"

THRA - do inglês "thyroid hormone receptor, alpha"

TIE1 - do inglês "tyrosine kinase with immunoglobulin-like and EGF-like domains 1"

TNF - do inglês "tumor necrosis factor alpha"

TNFRSF10C - do inglês "tumor necrosis factor receptor superfamily, member 10c, decoy without an intracellular domain"

TNFRSF1A - do inglês "tumor necrosis factor receptor superfamily, member $1 A$ "

TNFRSF1B - do inglês "tumor necrosis factor receptor superfamily, member 1B"

TNFRSF4 - do inglês "tumor necrosis factor receptor superfamily, member 4"

TNFSF13 - do inglês "tumor necrosis factor (ligand) superfamily, member 13"

TP53 - do inglês "tumor protein p53"

TRADD - do inglês "TNFRSF1A-associated via death domain"

TRAF2 - do inglês "TNF receptor-associated factor 2"

TRIM28 - do inglês "tripartite motif containing 28"

TSC1 - do inglês "tuberous sclerosis 1"

TSC2 - do inglês "tuberous sclerosis 2"

TYRO3 - do inglês "TYRO3 protein tyrosine kinase"

UHRF1 - do inglês "ubiquitin-like with PHD and ring finger domains 1"

USF2 - do inglês "upstream transcription factor 2, c-fos interacting"

VANGL1 - do inglês "vang-like 1 (van gogh, Drosophila)"

VEGFA - do inglês "vascular endothelial growth factor $A$ "

VEGFB - do inglês "vascular endothelial growth factor $B$ "

VTN - do inglês "vitronectin"

WNT5B - do inglês "wingless-type MMTV integration site family, member 5B"

XIAP - do inglês " $X$-linked inhibitor of apoptosis"

ZBTB38 - do inglês "zinc finger and BTB domain containing 38"

ZBTB48 - do inglês "zinc finger and BTB domain containing 48"

ZEB1 - do inglês "zinc finger E-box binding homeobox 1"

ZFP36L2 - do inglês "ZFP36 ring finger protein-like 2"

ZNF174 - do inglês "zinc finger protein 174"

ZNF256 - do inglês "zinc finger protein 256"

ZNF85 - do inglês "zinc finger protein 85"

ZRANB2 - do inglês "zinc finger, RAN-binding domain containing 2" 


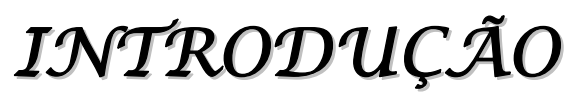




\section{INTRODUÇÃO}

\subsection{DOENÇAS AUTOIMUNES}

As doenças autoimunes (DAls) constituem grupo de doenças complexas e heterogêneas caracterizadas por alterações nos processos de tolerância imunológica, resultando na ativação de mecanismos efetores celulares e humorais, com consequente destruição tecidual por linfócitos autorreativos (MARRACK et al., 2001; MACKAY et al., 2008).

A tolerância imunológica pode ser definida como a não-responsividade aos antígenos próprios, devido à exposição prévia aos mesmos (OHASHI, 2003; RIOUX \& ABBAS, 2005; MATHIS \& BENOIST, 2010). A tolerância central é induzida em linfócitos imaturos pelo reconhecimento dos autoantígenos nos órgãos linfoides primários, timo para os linfócitos T e medula óssea para os linfócitos B (KAMRADT \& MITCHISON, 2001; GOODNOW et al., 2005; CARPENTER \& BOSSELUT, 2010). No entanto, alguns linfócitos autorreativos maduros escapam do processo de tolerância central e caem na circulação, onde serão controlados pelos mecanismos de tolerância periférica (RIOUX \& ABBAS, 2005). $\mathrm{Na}$ periferia, os linfócitos autorreativos podem ser silenciados pela inativação funcional ou anergia, deleção por apoptose induzida por ativação e supressão da resposta imune pelas células T reguladoras (Tregs) (GOODNOW et al., 2005; MUELLER, 2010).

As DAls atingem cerca de 5 a $8 \%$ da população mundial, acometendo principalmente as mulheres (BAECHLER et al., 2006; NUSSINOVITCH \& SHOENFELD, 2012). A etiologia das DAls não está completamente elucidada, mas acredita-se que envolva a interação de fatores genéticos, ambientais e alterações em processos de regulação do sistema imune (MARRACK et al., 2001; RIOUX \& ABBAS, 2005; MACKAY et al., 2008). Além disso, estudos em modelos animais demonstraram que o transplante de medula óssea de camundongos com DAls para camundongos sadios induzia o desenvolvimento da doença no camundongo saudável. Essas observações levaram os pesquisadores a proporem a hipótese de que a etiologia e patogênese de DAls podem ser atribuídas a alterações intrínsecas nas células-tronco presentes na medula óssea (IKEHARA et al., 1990; IKEHARA et al., 1994; IKEHARA, 1998; IKEHARA, 2003; IKEHARA, 2008).

A maioria das DAls são multigênicas e várias delas estão associadas a um ou mais alelos HLA de classe I ou II específicos, que podem conferir suscetibilidade ou resistência à doença (MAAS et al., 2002; MACKAY et al., 2008; COSTENBADER et al., 2012). Apesar da importância dos fatores genéticos, a discordância em estudos com gêmeos idênticos apontam para a contribuição de fatores ambientais no desencadeamento da autoimunidade (ERMANN \& FATHMAN, 2001; MARRACK et al., 2001, OWENS et al., 2011). 
Dentre os fatores ambientais envolvidos no desencadeamento das DAls estão os agentes infecciosos, que podem induzir a perda da autotolerância por mecanismos como o mimetismo molecular, exposição de antígenos crípticos e ativação de receptores intracelulares, que vão induzir a expressão de citocinas pró-inflamatórias e ativação de células da imunidade adaptativa (RYAN et al., 2007; CHERVONSKY, 2010).

Além dos fatores genéticos e ambientais, defeitos nos processos de regulação do sistema imune, tais como alterações no número e função de Tregs e resistência de células $T$ efetoras à supressão por essas células, podem desempenhar papel importante na perda da tolerância e, consequentemente, no desencadeamento da autoimunidade (BUCKNER, 2010; WING \& SAKAGUSHI, 2010). Trabalhos relatam que diferenças em número e função das Tregs estão relacionadas à patogênese de algumas DAls, incluindo a esclerose múltipla (LAWSON et al., 2008; LONG et al., 2010; BUCKNER, 2010).

\subsection{ESCLEROSE MÚLTIPLA}

A esclerose múltipla (EM) é doença crônica e inflamatória do sistema nervoso central (SNC), caracterizada pela destruição de proteínas constituintes da mielina pela reação autoimune de linfócitos $\mathrm{T} \mathrm{CD}^{+} \mathrm{Th} 1$, Th17, linfócitos $\mathrm{T} \mathrm{CD}^{+}$, autoanticorpos e micróglia ativada (TRAPP \& NAVE, 2008; NYLANDER \& HAFLER, 2012). As lesões inflamatórias observadas nos pacientes com essa doença estão associadas à formação de placas escleróticas e à presença de desmielinização no SNC, ocasionando várias disfunções neurológicas tais como incapacidades por deficiências de função motora, neurocognitiva e autonômica (LUTTON et al., 2004; KORN, 2008; NYLANDER \& HAFLER, 2012).

Em seu início, a EM é clinicamente caracterizada como surto-remissiva (SR), observada em $85-90 \%$ dos pacientes, ou progressiva primária (PP), observada em 10-15\% dos pacientes. Os surtos são causados pela quebra da barreira hemato-encefálica e entrada de linfócitos T autorreativos ativados no SNC, causando inflamação aguda associada ao edema (COMPSTON \& COLES, 2002; HAFLER, 2004; STYS, 2012). O aumento na frequência desses surtos e recuperação inadequada nos primeiros anos da doença clínica prediz deterioração mais rápida. A presença de múltiplas lesões gadolíneo-positivas nas imagens por ressonância magnética nuclear indica a ruptura da barreira hemato-encefálica, inflamação e curso mais grave da doença (COMPSTON \& COLES, 2002; HAFLER, 2004; STEINMAN, 2009; STYS, 2012).

Com a evolução da doença, usualmente, a capacidade de recuperação após os surtos diminui e os danos neurológicos aumentam. Aproximadamente $40 \%$ dos pacientes com EM-SR param de apresentar surtos e desenvolve desordem neurodegenerativa 
progressiva secundária (PS), associada à inflamação crônica do SNC. A evolução da EMPS está associada com diminuição significativa da frequência de lesões e do volume do parênquima cerebral (atrofia cerebral). No entanto, com o passar do tempo, a resposta da doença à imunossupressão diminui, podendo progredir para formas mais avançadas da doença (COMPSTON \& COLES, 2002; STEINMAN, 2009; STYS, 2012).

A etiologia da EM não está completamente elucidada, mas sabe-se que envolve a interação de fatores genéticos e ambientais para o seu desencadeamento (HEMMER et al. 2002; SOSPEDRA \& MARTIN, 2005). A EM é altamente prevalente em caucasianos e estima-se que mais de um milhão de pessoas em todo o mundo sejam afetadas (GOVERMAN, 2009). Ela atinge preferencialmente adultos jovens entre 15 e 45 anos, sendo as mulheres duas vezes mais afetadas (PAYNE et al., 2008; OWENS et al., 2011; NYLANDER \& HAFLER, 2012).

A EM desenvolve-se em indivíduos geneticamente suscetíveis e parentes de primeiro grau de indivíduos afetados têm risco maior (20-50 vezes) de desenvolver a doença e a taxa de concordância entre gêmeos idênticos varia de $20-35 \%$ em diferentes estudos (HEMMER et al. 2002; SOSPEDRA \& MARTIN, 2005). Algumas das associações genéticas mais relevantes com a EM são dos alelos HLA de classe II, em particular os grupos de alelos HLA-DR15 e DQ1 em diversas populações mundiais (LAAKSONEN et al., 2002, LUTTON et al., 2004) e com o alelo DRB1*1501 na população brasileira (BRUM et al, 2010). Outros estudos identificaram alguns alelos dos genes que codificam a cadeia $\alpha$ das interleucinas 2 e 7 como associados ao desenvolvimento da EM (HAFLER et al., 2007).

Dentre os fatores ambientais envolvidos no desencadeamento da EM estão as infecções virais, principalmente pelo vírus Epstein-Barr (EBV), que mostrou ter influência no desenvolvimento da doença, uma vez que estudos demonstraram que $99 \%$ dos pacientes com EM são soropositivos para o EBV (ASCHERIO \& MUNCH, 2000; PENDER \& GREER, 2007).

Grande parte do conhecimento atual sobre a etiologia e patogênese da EM é proveniente de estudos em modelos experimentais. Trabalhos mostraram que a injeção de componentes proteicos da bainha de mielina, juntamente com adjuvante em camundongos, causava encefalomielite autoimune experimental (EAE) (BEN-NUN \& COHEN, 1982). A EAE também é induzida em camundongos pela transferência adotiva de células $T$ reativas contra mielina, mas não pela transferência de autoanticorpos. Esse fato levou os pesquisadores a concluírem que a EM constitui doença mediada principalmente por células T (BEN-NUN \& COHEN, 1982; IRANI, 2005). A MBP (myelin basic protein), a PLP (proteolipid protein) e a MOG (myelin oligodendrocyte glycoprotein) constituem os antígenos-alvo das células T autorreativas e de autoanticorpos no SNC de pacientes com EM (PENDER \& GREER, 2007; LASSMANN et al., 2011). 
As células $\mathrm{T} \mathrm{CD}^{+}$Th1 autorreativas apresentam papel central na patogênese da EM, pois contribuem para o infiltrado de células inflamatórias encontradas no SNC e no líquor, para a produção de autoanticorpos, e ainda, para a ativação de células T CD8 ${ }^{+}$ autorreativas (LUTTON et al., 2004; IRANI, 2005; GREENSTEIN, 2007). No contexto de funções efetoras, as células T CD8 ${ }^{+}$estão mais envolvidas com os danos no SNC do que as células $\mathrm{T} \mathrm{CD}^{+}$, fato evidenciado pelas expansões oligoclonais proeminentes de células $\mathrm{T}$ $\mathrm{CD8}^{+}$encontradas no líquor e no SNC de pacientes com EM. Em resumo, ambas as respostas de células $\mathrm{T} \mathrm{CD} 4^{+}$e $\mathrm{T} C D 8^{+}$contribuem para patogênese da $E M$, embora em diferentes estágios e com funções distintas (IRANI, 2005; PETERSON \& FUJINAMI, 2007; HERZ et al., 2010).

Os níveis de imunoglobulinas encontram-se elevados no líquido cefalorraquidiano de pacientes com EM, indicando produção local de autoanticorpos por células B (IRANI, 2005). Recentemente, foram descobertas estruturas similares aos folículos linfoides de células $B$ com centros germinais nas meninges de pacientes com EM-PS. Esses folículos ectópicos contêm células $B$ em proliferação, plasmócitos, células $T$ e células dendríticas. Acredita-se, portanto, que esses centros germinais nas meninges sejam sítios de ativação e proliferação de células $B$ e T reativas à mielina no SNC (SERAFINI et al., 2004; PENDER \& GREER, 2007; NYLANDER \& HAFLER, 2012).

Alguns estudos mostraram que células Th17 também podem desempenhar papel essencial na patogênese da EAE, anteriormente considerada como DAl mediada por linfócitos T CD4 ${ }^{+}$de padrão Th1 (COOKE, 2006; BETELLI et al., 2007). Estudos em modelos experimentais mostraram que células Th17 participam da patogênese da EAE (KIKLY et al., 2006; BETELLI et al., 2007). Em humanos, foi mostrado que $40 \%$ dos pacientes com EM apresentam números elevados de células mononucleares positivas para mRNA de IL17A no sangue periférico e no líquor, comparando-se com controles (MATUSEVICIUS et al., 1999; LOCK et al., 2002; TZARTOS et al., 2008). Além disso, pacientes com altos níveis séricos de IL-17A têm menor resposta ao tratamento com IFN- $\beta$ quando comparados aos pacientes com níveis baixos de IL17A, que em geral, têm boa resposta aos imunomoduladores (BALASA et al., 2012).

Vários trabalhos têm demonstrado que as células Treg $C D 4^{+} C D 25^{\text {hi }}$ de pacientes com EM são funcionalmente defeituosas ou possuem alterações nos processos de maturação e emigração do timo (HAAS et al., 2005; KUMAR et al., 2006; BUCKNER, 2010). Estudos revelaram número reduzido de Tregs em pacientes com EM, bem como expressão reduzida de Foxp3 (HUAN et al., 2005). Outra investigação demonstrou frequência normal de Tregs em pacientes com EM, porém detectaram diminuição da capacidade das T reguladoras de suprimir a proliferação de células $T$ CD25 em resposta à ativação policlonal (VIGLIETTA et al., 2004; ZOZULYA \& WIENDL, 2008; BUCKNER, 2010). 
Dentre as abordagens terapêuticas convencionais utilizadas no tratamento da EM estão o uso de drogas imunossupressoras que inibem a resposta imune de padrão Th1 e diminuem a migração de células $T$ através da barreira hemato-encefálica, e ainda, a terapia com imunomoduladores (IFN- $\beta$, acetato de glatiramer ou copaxone) que aumentam a expressão de citocinas anti-inflamatórias como TGF- $\beta$ e IL-10 (HOHLFELD \& WEKERLE, 2004; VIRLEY, 2005). No entanto, alguns pacientes com EM não respondem a essas terapias convencionais, e uma estratégia terapêutica que vem sendo utilizada em vários centros de referência é a terapia de imunossupressão seguida do transplante autólogo de células-tronco hematopoéticas (TACTH) (BURT et al., 2005; MURARO et al., 2005; VOLTARELLI et al., 2007; BURT et al., 2008; BURT et al., 2012) e, mais recentemente, em ensaios clínicos de fase $\mathrm{I} / \mathrm{II}$, o transplante autólogo de células-tronco mesenquimais (KARUSSIS et al., 2010; YAMOUT et al., 2010; CONNICK et al., 2012; UCCELLI et al., 2012).

\subsection{CÉLULAS-TRONCO HEMATOPOÉTICAS E ESTROMAIS MESENQUIMAIS}

As células-tronco hematopoéticas (CTHs) e as estromais mesenquimais multipotentes (CTMs) compõem o chamado nicho de células-tronco na medula óssea, importantes para a manutenção do pool de células-tronco e da hematopoese (WILSON \& TRUMPP, 2006; MERCIER et al., 2012). As CTHs são populações de células raras e multipotentes que dão origem a todas as células dos sistemas hematopoético e imunológico e são caracterizadas pela expressão da molécula de superfície CD34 e ausência de marcadores de linhagem linfoide e mieloide (KONDO et al., 2003; HUANG et al., 2007; ORKIN \& ZON, 2008).

Os nichos endosteal e vascular na medula óssea cooperam na manutenção da quiescência e autorrenovação das CTHs. As CTHs quiescentes, em fase G0, encontram-se em contato íntimo com os osteoblastos no nicho endosteal e as CTHs em divisão (autorrenovação e geração de progenitores multipotentes) podem ser encontradas no nicho endosteal e no estroma entre os sinusoides, em contato próximo com o nicho vascular (WILSON \& TRUMPP, 2006; WANG \& WAGERS, 2011; MERCIER et al., 2012). As áreas adjacentes aos vasos sanguíneos na medula óssea são ricas em CTHs e as células endoteliais desses vasos expressam moléculas de adesão (E-selectina e VCAM1) e quimiocinas (CXCL12) que facilitam o trânsito das CTHs e células do sistema imune da medula óssea para a periferia (BIANCO, 2011; MERCIER et al., 2012).

Além disso, fatores solúveis produzidos por células do estroma medular são importantes na manutenção das CTHs. Dentre esses fatores estão: i) a angiopoetina (Ang-1) produzida pelos osteoblastos desempenha papel na quiescência das CTHs; ii) a quimiocina 
CXCL12, expressa pelas células estromais (osteoblastos, estromais mesenquimais e endoteliais vasculares), têm papel essencial na migração, mobilização e retenção das CTHs na medula óssea, mantendo o pool de células-tronco no nicho; iii) o fator SCF (stem cell factor) produzido por osteoblastos, células endoteliais e mesenquimais, tem papel na manutenção e autorrenovação das CTHs; iv) os ligantes de Notch estão presentes nas células endoteliais e osteoblastos, estão envolvidos com o aumento do número de CTHs na medula óssea, e ainda, com a posterior diferenciação em linhagens específicas; v) a trombopoetina produzida pelos osteoblastos está relacionada com a manutenção das CTHs em estado quiescente; e vi) os ligantes de Wnt são expressos nos osteoblastos e estão relacionados com a autorrenovação das CTHs (SUGIYAMA et al., 2006; FLEMING et al., 2008; BIANCO, 2011; MERCIER et al., 2012).

Em resposta ao estresse, infecções e sinais inflamatórios, as CTHs quiescentes são ativadas e recrutadas do nicho endosteal para o nicho vascular, onde produzem progenitores multipotenciais (MPPs) que dão origem a todas as linhagens hematopoéticas (megacariocíticas, mieloides e linfoides) e migram para o sangue periférico (WILSON \& TRUMPP, 2006; KING \& GOODELL, 2011; MERCIER et al., 2012). Sinais provenientes da liberação de citocinas pró-inflamatórias, tais como TNF, IL-1, IL-6, IL-8 e sinalização do IFN$\gamma$ interferem nos compartimentos estromais das CTHs, induzindo proliferação das CTHs, migração para a periferia e hipocelularidade medular (KING \& GOODELL, 2011).

Além das CTHs, a medula óssea contém precursores de linhagens nãohematopoéticas que incluem as células-tronco mesenquimais. No entanto, apenas pequena subpopulação dessas células possuem propriedades de células-tronco (autorrenovação, proliferação indefinida, plasticidade). Por esse motivo, o termo células estromais mesenquimais multipotentes (Multipotent Mesenchymal Stromal Cells - CTMs) foi introduzido durante reunião da Sociedade Internacional de Terapia Celular (ISCT) para se referir a essa população de células aderentes ao plástico, de morfologia fibroblastoide e capacidade de diferenciação multipotencial (HORWITZ et al., 2005; ZHANG et al., 2005; DOMINICl et al., 2006).

As CTMs compreendem população rara de progenitores multipotentes que contribuem para a regeneração de tecidos mesenquimais tais como: ósseo, cartilaginoso, muscular, ligamento, tendão, tecido adiposo e estroma medular, além de exercerem papel fundamental na sustentação da hematopoese (DAZZI et al., 2006). Elas constituem pequena fração nestina positiva $(0,001 \%$ a $0,1 \%)$ das células nucleadas presentes na medula óssea e estão localizadas nas regiões centrais, no nicho perivascular em contato próximo com as CTHs. Além disso, essas CTMs estão associadas a fibras nervosas adrenérgicas do sistema nervoso simpático que regulam a mobilização e oscilações nos números de CTHs no nicho e expressam altos níveis de moléculas envolvidas com a manutenção das CTHs, dentre 
elas, CXCL12, SCF, Ang-1, IL-7, VCAM1 e osteopontina (EHNINGER \& TRUMPP, 2011; MERCIER et al., 2012). A deleção das CTMs nestina positivas na medula óssea induz redução de $50 \%$ nos números de $\mathrm{CTH}$ e aumento proporcional dessas células no baço (MERCIER et al., 2012).

Além da medula óssea, alguns estudos mostraram que as CTMs apresentam localização sistêmica na parede de todos os vasos sanguíneos do organismo (COVAS et al., 2008; DA SILVA MEIRELLES et al., 2008; CRISAN et al., 2008). Com base nesses estudos, tem sido proposto que os vasos sanguíneos constituam nichos relevantes de CTMs, que possuem funções fisiológicas in vivo tais como a proteção dos tecidos injuriados contra respostas imunes exacerbadas (imunorregulação) e de reposição celular/regeneração tecidual (DA SILVA MEIRELLES et al., 2008; CRISAN et al., 2008). Esses trabalhos sugerem ainda, que defeitos nos processos de imunorregulação mediados pelas CTMs poderiam resultar no desenvolvimento de autoimunidade e, consequentemente, em DAls (DA SILVA MEIRELLES et al., 2008; DAZZI \& MARELLI-BERG, 2008).

As CTMs são de fácil isolamento, expansão, cultivo e diferenciação in vitro em alguns tipos celulares da linhagem mesodérmica e, além da medula óssea, as CTMs podem ser isoladas do sangue de cordão umbilical, veia umbilical, veia safena, parede de artérias, de tecidos fetais, placenta, tecido adiposo e da polpa dentária (PITTENGER et al., 1999; COVAS et al., 2008; DA SILVA MEIRELLES et al., 2008; UCCELLI et al., 2008). Caracterizam-se pela baixa expressão de $\mathrm{MHC}$ de classe II, moléculas coestimulatórias (tais como CD40, CD80 e CD86) e ausência de marcadores de linhagens hematopoéticas, tais como CD34, CD45, CD14, glicoforina A, CD3 e CD19, e ainda, de marcadores de células endoteliais como CD31 e KDR. Por outro lado, as CTMs apresentam alta expressão de MHC de classe I, CD90, CD73 e CD105, os quais constituem seus principais marcadores. Além desses marcadores, as CTMs também expressam CD13, CD29, CD44, CD54, CD146 e CD166. Pela baixa expressão de MHC de classe II e de moléculas coestimulatórias, as CTMs apresentam fenótipo hipoimunogênico (LE BLANC \& RINGDÉN, 2005). Assim, tem sido sugerido que as CTMs escapem da vigilância do sistema imune por possuírem antígenos de superfície que são pobremente reconhecidos pelas células $\mathrm{T}$ alorreativas $\mathrm{e}$ células NK. Sendo assim, trabalhos da literatura sugerem que elas possam ser transplantadas de forma autóloga, alogênica e em xenoenxertos (ZHANG et al., 2005; RODRIGUEZ et al., 2005; VIEIRA et al., 2008).

As CTMs apresentam propriedades importantes de imunossupressão e imunorregulação in vitro e in vivo. Elas apresentam a capacidade de modular a função de várias populações celulares do sistema imune inato e adaptativo (RASMUSSON et al., 2003; UCCELLI et al., 2006; UCCELLI et al., 2008; DE MIGUEL et al., 2012; LE BLANC \& MOUGIAKAKOS, 2012). Di Nicola e colaboradores (2002) mostraram que a proliferação de 
linfócitos T humanos, estimulados pela adição de linfócitos alogênicos, células dendríticas ou por fitohemaglutinina, era significativamente suprimida quando as culturas continham CTMs. Corroborando esses achados, Le Blanc e colaboradores (2003) mostraram que as CTMs exercem efeito imunossupressor em culturas mistas de linfócitos, nas quais, em elevadas proporções, suprimiam a alorreatividade das células $T$, com redução da proliferação de linfócitos induzida por fitohemaglutinina (LE BLANC et al., 2003). Posteriormente, outros trabalhos demonstraram que as CTMs inibem a proliferação de células $T$ pela regulação negativa da expressão de ciclina D2 e que a inibição da proliferação deve-se à ativação da via de sinalização por PD-1 (GLENNIE et al., 2005; AUGELLO et al., 2005). Ademais, foi visto que a capacidade supressora das CTMs depende da produção de IL-1 $\beta$ pelos monócitos, pois essa citocina induz as CTMs a produzirem TGF$\beta 1$, citocina anti-inflamatória envolvida com a supressão de linfócitos (GROH et al., 2005; UCCELLI et al., 2008; LE BLANC \& MOUGIAKAKOS, 2012).

Além de atuarem sobre linfócitos $T$, outros trabalhos mostraram que as CTMs exercem regulação geral sobre as respostas imunes, atuando também sobre outras células do sistema imune inato e adaptativo (AGGARWAL \& PITTENGER, 2005; DE MIGUEL et al., 2012). Alguns estudos têm demonstrado que as CTMs inibem a diferenciação de monócitos e progenitores hematopoéticos em células dendríticas in vitro, promovem diminuição da expressão de MHC de classe II e moléculas coestimuladoras nas células dendríticas e diminuição da secreção de IL-12 e TNF por essas células, prejudicando sua função de apresentação antigênica (UCCELLI et al., 2008; DE MIGUEL et al., 2012). Maccario e colaboradores (2005) demonstraram que a adição de CTMs humanas em cultura mista de linfócitos inibe a diferenciação de células dendríticas mieloides e favorece a diferenciação de subpopulações de células $\mathrm{T} \mathrm{CD}^{+}$de fenótipo regulatório. Outro trabalho mostrou que as CTMs inibem respostas de células $T$ de memória, impedindo o contato físico dessas células com as apresentadoras de antígenos de maneira inespecífica (KRAMPERA et al., 2003).

Além da atuação sobre as populações de células dendríticas, estudos mostraram que o cocultivo de monócitos com CTMs humanas ou de camundongos induzia a polarização de macrófagos M2 em cultura, com alta produção de IL-10 e baixos níveis de TNF, IL-12, IFN- $\gamma$ e baixa expressão de MHC de classe II (NAUTA \& FIBBE, 2007; MAGGINI et al., 2010; FRANÇOIS et al., 2012; LE BLANC \& MOUGIAKAKOS, 2012). Além disso, foi descrito que as CTMs secretam o antagonista do receptor da IL-1 (IL-1RA) que previne a liberação de TNF por macrófagos ativados (ORTIZ et al., 2007; LE BLANC \& MOUGIAKAKOS, 2012), diminuindo seu potencial pró-inflamatório.

As CTMs interferem também com a atividade de células NK, pois foi demonstrado em experimentos de cocultivo de CTMs e células NK, ativadas com IL-2 ou IL-15, que as CTMs inibiam a atividade citotóxica das células NK, bem como a produção de citocinas, 
liberação de granzima B e expressão de receptores de ativação (NKp30, NKp44 e NKG2D) in vitro (BÜHRING et al., 2007; UCCELLI et al., 2008; LE BLANC \& MOUGIAKAKOS, 2012).

Um dos mecanismos propostos pelos quais as CTMs modulam as respostas imunes é a indução de células T reguladoras (Tregs) (NAUTA \& FIBBE, 2007; UCCELLI, 2008; ENGLISH, 2013). Trabalhos mostraram o papel das CTMs no recrutamento e regulação das Tregs (DI IANNI et al., 2008), bem como a capacidade de indução e expansão dessas células em cocultivos de CTMs e células mononucleares (ENGLISH et al., 2009, BURR et al., 2013). English e colaboradores (2009), demonstraram que CTMs humanas isoladas da medula óssea induzem células Tregs in vitro pela liberação de TGF- $\beta 1$ e PGE2 e pelo contato célula-célula, promovendo a expressão de Foxp3 e CD25 hi nas células $\mathrm{T} C D 4^{+}$. Além disso, estudos mostraram que as CTMs suprimem a produção de citocinas pró-inflamatórias, como IL-17 e IL-22, pelas células Th17 e induzem reprogramação dessas células diferenciadas $\mathrm{ROR}_{\mathrm{r}} \mathrm{t}^{+}$em células $\mathrm{T}$ reguladoras Foxp $3^{+}$, produtoras de IL-10 (GHANNAM et al., 2010; DUFFY et al., 2011; LE BLANC \& MOUGIAKAKOS, 2012).

Além dos efeitos sobre células da imunidade inata e linfócitos $T$, estudos mostraram que as CTMs são capazes de inibir a proliferação dos linfócitos $B$, diferenciação e produção de anticorpos, de maneira dose-dependente (CORCIONE et al., 2006; UCCELLI et al., 2008; DE MIGUEL et al., 2012). Após estímulo dos linfócitos B com LPS, CpG, CD40L, IL-2, IL-4 ou IL-10 e cocultivo com CTMs, foi observado inibição da proliferação de linfócitos $B$, bem como da produção de imunoglobulinas (CORCIONE et al., 2006; ASARI et al., 2009). O bloqueio da expressão de Blimp-1, proteína necessária para produção das imunoglobulinas, representa um dos mecanismos de imunossupressão pelas CTMs (RAFEl et al., 2008; ASARI et al., 2009; DE MIGUEL et al., 2012).

Vários mecanismos vêm sendo evidenciados como responsáveis pela capacidade imunomoduladora das CTMs e, atualmente, há consenso de que a secreção de fatores solúveis por essas células desempenhe papel fundamental na sua atividade supressora. Alguns desses fatores solúveis são produzidos constitutivamente pelas CTMs e outros são induzidos após o licenciamento das CTMs em microambientes inflamatórios (DAZZI et al., 2012). Dentre estes fatores solúveis estão a indoleamina 2,3-dioxigenase (IDO), prostaglandina E2 (PGE2), TGF- $\beta 1$, IL-6, HGF (hepatocyte growth factor), LIF (leukemia inhibitory factor) e HLA-G5, além de metaloproteinases e quimiocinas, que estão envolvidas no processo de imunomodulação (UCCELLI et al., 2008; BASSI et al., 2012; DAZZI et al., 2012). Recentemente, foi descrito que a galectina-1, altamente expressa na superfície das CTMs, pode ser liberada em forma solúvel e mediar os efeitos imunossupressores sobre linfócitos T (GIESEKE et al., 2010, DAZZI et al., 2012). 
A IDO é produzida pelas CTMs após o licenciamento das CTMs por IFN- $\gamma$ e induz a depleção do triptofano, aminoácido essencial para a proliferação dos linfócitos (DAZZI \& MARELLI-BERG, 2008; UCCELLI et al., 2008; LE BLANC \& MOUGIAKAKOS, 2012). Além do IFN- $\gamma$, outras citocinas pró-inflamatórias como TNF, IL-1 $\alpha$ e IL-1 $\beta$ estimulam as CTMs a produzirem mais fatores que inibem a proliferação dos linfócitos, como COX2 e mais IDO (UCCELLI et al., 2008; LE BLANC \& MOUGIAKAKOS, 2012, DAZZI et al., 2012). Além disso, trabalhos com modelos animais mostraram que a IDO desempenha papel essencial no efeito imunossupressor das CTMs e está associada com a indução de tolerância a enxertos in vivo, por meio da indução da expansão de células T reguladoras (BASSI et al., 2012).

Alguns fatores solúveis como TGF- $\beta 1$, HGF, PGE2, IL-6 e HLA-G5 são constitutivamente produzidos pelas CTMs, e alguns deles podem ter sua produção aumentada pelas citocinas liberadas na interação das CTMs com as células-alvo (UCCELLI et al., 2008). A secreção de TGF- $\beta 1$ pelas CTMs induz a expressão de CD25 e Foxp3 em células mononucleares do sangue periférico após cocultivo com CTMs, de maneira dependente de TGF- $\beta 1$ e PGE2. Além disso, atualmente, o TGF- $\beta 1$ é considerado responsável pelo efeito imunossupressor das CTMs sobre os linfócitos $\mathrm{TCD}^{+}$in vitro e in vivo, associado a outros fatores tróficos, como HGF e PGE2 (BASSI et al., 2012; BURR et al., 2013). Além do papel imunomodulador do HGF, em conjunto com o TGF- $\beta 1$, essa molécula secretada pelas CTMs possui potencial regenerativo com efeitos angiogênicos, promovendo reparação tecidual após injúria e contribuindo para o efeito terapêutico dessas células em modelos de doenças (BAI et al. 2012; BASSI et al., 2012).

A PGE2 secretada pelas CTMs desempenha papel importante nos efeitos imunossupressores sobre as células dendríticas e linfócitos $T$, e citocinas inflamatórias como IFN- $\gamma$, TNF e IL-1 $\beta$ aumentam a expressão de COX2 e a subsequente produção de PGE2 pelas CTMs (UCCELLI et al., 2008; YAÑEZ et al., 2010). O efeito imunossupressor das CTMs mediado pela PGE2 foi bem estabelecido por trabalhos utilizando anticorpos neutralizantes, inibição farmacológica e genética da via de sinalização da cicloxigenase (BASSI et al., 2012).

Recentemente, foi demonstrado o envolvimento de outra molécula, a HLA-G5, na regulação imune mediada pelas CTMs. A produção HLA-G5 na forma solúvel é estimulada por IL-10 e leva à supressão da proliferação de linfócitos $T$, da citotoxicidade de células NK e T $\mathrm{CD}^{+}$, induz produção de citocinas de padrão Th2, além de promover a geração de células T reguladoras (UCCELLI et al., 2008; FAINARDI et al., 2011; BASSI et al., 2012).

Além dos efeitos imunossupressores e imunorreguladores das CTMs, foi demonstrado que essas células, assim como os macrófagos, podem sofrer polarização 
dependendo do microambiente em que se encontram (WATERMAN et al., 2010). As CTMs expressam níveis basais de receptores de reconhecimento padrão (TLRs) e sua expressão é aumentada em condições de hipóxia (TLRs 1, 2, 5 e 9) e inflamação (TLRs 2, 3 e 4). Estudos mostraram que a ativação de CTMs humanas por TLR4 induzem padrão próinflamatório, com produção de IL-6, IL-8 e TGF- $\beta$ (denominado padrão CTM-1), enquanto a ativação por TLR3 favorece padrão anti-inflamatório, com aumento da expressão de IDO, COX2, IL-4 e IL-1RA (padrão CTM-2) (HWA CHO et al., 2006; RAICEVIC et al., 2010). Os autores desses trabalhos sugerem que, in vivo, quando as CTMs infiltram tecidos infectados elas contribuem com a resposta antimicrobiana, na qualidade de CTM-1, e quando a inflamação é persistente e há destruição tecidual, o TLR3 é ativado e favorece a polarização para CTM-2, promovendo resolução da inflamação e regeneração tecidual (CAVASSANI et al., 2008). No entanto, os dados com relação aos efeitos da ativação de TLR3 ou TLR4 sobre a capacidade supressora das CTMs na proliferação de linfócitos ainda são controversos (LE BLANC \& MOUGIAKAKOS, 2012).

Existem estudos na literatura sobre o uso de CTMs para indução de tolerância imune. A indução de tolerância periférica é crítica para a prevenção da autoimunidade e manutenção da homeostasia imune. Esses trabalhos têm mostrado o imenso potencial dessas células para serem usadas como "células tolerogênicas" ou "indutoras de tolerância" no tratamento de doenças imuno-mediadas ou inflamatórias, devido à sua grande capacidade imunorreguladora (FANDRICH et al., 2002; LE BLANC \& RINGDEN, 2005; BURT et al., 2008).

Os efeitos imunomoduladores in vivo das CTMs têm sido estudados em ampla variedade de modelos animais. Um dos primeiros estudos in vivo demonstrou que a infusão sistêmica de CTMs, derivadas de medula óssea de babuínos, prolongava a sobrevida de enxertos de pele alogênicos (BARTHOLOMEW et al., 2002). Outro trabalho mostrou que CTMs singênicas diminuem a rejeição de células de medula óssea alogênicas em modelo murino, entretanto, os mecanismos imunológicos envolvidos não foram estabelecidos (NAUTA et al., 2006). O efeito imunossupressor mais expressivo das CTMs, in vivo, foi mostrado no tratamento da doença do enxerto contra o hospedeiro (DECH). Nesse estudo, a infusão sistêmica de CTMs derivadas de tecido adiposo e expandidas ex vivo foram eficientes no controle da DECH desenvolvida em camundongos após o transplante de CTHs haploidênticas (SUDRES et al., 2006). Além disso, foi mostrado que o uso de CTMs em modelos de EAE foi capaz de induzir tolerância periférica de células $T$ contra antígenos próprios (NAUTA \& FIBBE, 2007; BAl et al., 2009).

Além da modulação de respostas imunes, outra propriedade das CTMs consiste em sua capacidade de migração para o sítio de injúria tecidual e inflamação, envolvendo a expressão de vários receptores de quimiocinas (CXCR4, CXCR5, CXCR6, CCR1, CCR7 e 
CCR9), na superfície das CTMs (BURR et al., 2013). Esta extraordinária capacidade foi demonstrada em casos de fratura óssea, infarto do miocárdio e injúria cerebral isquêmica (LE BLANC \& PITTENGER, 2005). O interesse crescente na utilização das CTMs para a medicina regenerativa e para a engenharia de tecidos deve-se à sua multipotencialidade, fácil isolamento a partir de inúmeros tecidos, capacidade de migração in vivo e potencial de regeneração tecidual. Além disso, as CTMs secretam moléculas bioativas (citocinas ou fatores de crescimento e fatores angiogênicos) que auxiliam no reparo de tecidos lesados (UCCELLI et al., 2008).

Com base em suas propriedades de imunossupressão e imunorregulação, as CTMs passaram a ser utilizadas, recentemente, como tratamento para doenças humanas inflamatórias e autoimunes, e também na DECH (LE BLANC et al., 2004; LE BLANC et al., 2008). E devido suas propriedades de regeneração, as CTMs vêm sendo utilizadas no tratamento de doenças como a osteogênese imperfeita (HORWITZ et al., 2002), doenças cardiovasculares (BOYLE et al., 2006) e traumas de medula espinhal (PARK et al., 2005).

\subsection{TRATAMENTO DE DOENÇAS AUTOIMUNES COM CÉlULAS-TRONCO HEMATOPOÉTICAS E ESTROMAIS MESENQUIMAIS}

As CTHs, há muitos anos, têm sido utilizadas em transplantes autólogos e alogênicos para o tratamento de doenças hematológicas, tais como leucemias e linfomas e, recentemente, em transplantes autólogos para indução de tolerância no tratamento de doenças autoimunes (POPAT \& KRANCE, 2004; SYKES \& NIKOLIC, 2005).

O transplante de células-tronco hematopoéticas (TCTH) tem sido, ultimamente, alternativa terapêutica promissora para pacientes com DAls graves e refratárias aos tratamentos convencionais. O TCTH envolve a administração de CTHs que possuem a capacidade de autorrenovação e de originar todos os tipos celulares dos sistemas hematopoético e imunológico. (SYKES \& NIKOLIC, 2005; BOHGAKI et al., 2008; BURT et al., 2008; RESTON et al., 2011). A base racional dessa terapia é o restabelecimento da tolerância imunológica pela eliminação dos linfócitos autorreativos por meio de imunossupressão em altas doses (imunoablação) e o subsequente transplante das CTHs, visando a rápida reconstituição do sistema imune e hematopoético e evitando citopenias prolongadas (SYKES \& NIKOLIC, 2005; BURT et al., 2008).

Nos últimos anos, ensaios clínicos têm demonstrado que a terapia de imunossupressão em altas doses seguida do TACTH é eficaz no tratamento de doenças autoimunes graves e refratárias às terapias convencionais. Embora os resultados variem de doença para doença, mais de dois terços dos pacientes têm apresentado estabilização da doença ou remissões parciais, sem necessidade de uso de drogas imunossupressoras após 
o transplante (POPAT \& KRANCE, 2004; KOTTER et al., 2005; TYNDALL \& SACCARDI, 2005; BURT et al., 2008).

Entretanto, o mecanismo de ação dessa terapia ainda não está completamente elucidado (FARIAS, 2006, BURT et al., 2008). Algumas hipóteses foram formuladas para explicar o mecanismo de ação do TACTH em DAls: i) a imunoablação intensa elimina a resposta autoimune patogênica; ii) a reconstituição de novo sistema imune autotolerante, e iii) promoção de reparo tecidual (BURT et al., 2002; MURARO \& MARTIN, 2003). Atualmente, o mecanismo mais aceito é a reprogramação do sistema imunológico após o TACTH, em que a imunossupressão eliminaria os linfócitos B e T autorreativos de memória. Baseando-se na premissa de que fatores ambientais têm importante papel no desencadeamento das DAls, a eliminação do repertório de células B e T pré-existentes permitiria que o sistema imunológico do paciente reiniciasse do zero (reset imunológico), gerando novas células B e T autotolerantes (SYKES \& NIKOLIC, 2005; MURARO \& DOUEK, 2006; BURT et al., 2008; RESTON et al. 2011).

Os estudos que revelaram o potencial da terapia de imunossupressão seguida do TCTH para o tratamento da autoimunidade foram realizados em vários modelos experimentais de DAls. Esses estudos revelaram que o TCTH autólogo e o alogênico foram eficientes no tratamento de DAls experimentais. Os resultados sugeriram que ambas as abordagens seriam benéficas para o tratamento de pacientes com DAls refratárias, embora o TCTH autólogo seja mais seguro (VAN BEKKUM, 2002; VAN BEKKUM, 2003; VAN BEKKUM, 2004). Portanto, atualmente, o TCTH autólogo tem sido preferido ao alogênico em ensaios clínicos, devido ao potencial de rejeição observados em TCTH alogênicos. No entanto, alguns estudos em modelos animais indicam que DAls possam ser transferidas pelo transplante de CTHs de animais doentes para animais sadios. Desse modo, somente o transplante alogênico poderia promover a cura definitiva da doença (IKEHARA, 1998; IKEHARA, 2003; IKEHARA, 2008).

Desde 1990, mais de 350 pacientes com EM em todo o mundo foram tratados com o transplante de células-tronco hematopoéticas, sendo a grande maioria, transplantes autólogos para o tratamento de condições refratárias a terapias convencionais (KARUSSIS, 2012). De maneira geral, $85 \%$ dos pacientes acompanhados tiveram taxa de sobrevivência de 5 anos e $43 \%$ deles ficaram livres da progressão neurológica da doença (KARUSSIS, 2012).

Nos últimos anos, vários ensaios clínicos de imunossupressão seguido do TACTH foram realizados mundialmente em pacientes com EM, esclerose sistêmica, lúpus eritematoso sistêmico (LES), artrite reumatóide (AR), diabetes mellitus do tipo 1 (DM-1), dentre outras (BURT et al., 2003; HOUGH et al., 2005; TYNDALL \& SACCARDI, 2005). No Brasil, esse tratamento vem sendo realizado desde setembro de $2001 \mathrm{em}$ alguns centros, 
principalmente na Unidade de Transplante de Medula Óssea do Hospital das Clínicas da Faculdade de Medicina de Ribeirão Preto - Universidade de São Paulo (HCFMRP-USP) e no Hospital Albert Einstein em São Paulo. Pacientes portadores de formas graves e progressivas de EM, DM-1 e algumas doenças reumáticas são tratados com a terapia de imunossupressão seguida do TACTH (VOLTARELLI \& OUYANG, 2003; VOLTARELLI et al., 2007).

Com relação às CTMs, desde que surgiram vários trabalhos mostrando a capacidade dessas células de modular a resposta de células da imunidade inata (DAZZI et al., 2012; LE BLANC \& MOUGIAKAKOS, 2012) e adaptativa (RASMUSSON et al., 2003; UCCELLI et al., 2006; NAUTA \& FIBE, 2007; DA SILVA MEIRELLES et al., 2008; UCCELLI et al., 2008; AULETTA et al., 2012; DE MIGUEL et al., 2012), elas se tornaram alvos de estudos para terapia celular em doenças autoimunes e inflamatórias (TYNDALL \& UCCELLI, 2009; UCCELLI \& PROCKOP, 2010; BEN-AMI et al., 2011; DAZZI \& KRAMPERA, 2011; UCCELLI et al., 2012; COHEN, 2013).

Vários estudos em camundongos com EAE foram realizados, mostrando que o tratamento com CTMs diminuía a proliferação de linfócitos $\mathrm{T}$ contra mielina, diminuía a secreção de IFN- $\gamma$, TNF e IL-17, polarizando a resposta para o padrão Th2 (ZAPPIA et al., 2005; GERDONI et al., 2007; BAl et al., 2009). Foi observado também que as CTMs migravam para a região desmielinizada, promovia diminuição do infiltrado celular e reparação endógena (oligodendrogênese e astrogliose), pela liberação de HGF (BAl et al., 2009; BAl et al. 2012). Além disso, camundongos tratados exibiam aumento da frequência de células $T$ reguladoras, diminuição da extensão de áreas desmielinizadas e diminuição significativa do escore de atividade clínica (ZHANG et al., 2005; ZHANG et al., 2006; KASSIS et al., 2008; MORANDO et al., 2012).

A maioria dos ensaios clínicos de fase I/II utilizando as CTMs no tratamento da EM são autólogos e mostram que a intervenção é clinicamente viável e relativamente segura. No trabalho de Karussis e colaboradores (2010), foram tratados 21 pacientes com infusões intratecal e intravenosa de CTMs, sendo observada redução dos escores de atividade clínica após 6 meses da intervenção, migração de CTMs para a região dos ventrículos occipitais, aumento de células $T$ reguladoras $C D 4^{+} C D 25^{+}$e diminuição da proliferação de linfócitos após 24 horas da infusão das CTMs, mostrando seus efeitos imunomoduladores (KARUSSIS et al., 2010). Embora os mecanismos de ação que medeiam os efeitos imunorreguladores no tratamento da EAE com CTMs humanas não estejam elucidados, acredita-se que envolvam a interação célula-célula e a liberação de fatores solúveis, tróficos e citocinas anti-inflamatórias (AULETTA et al., 2012).

Os ensaios clínicos de fase I e II de Yamout e colaboradores (2010) e Connick e colaboradores (2012), ambos com casuística de dez pacientes com EM progressiva 
secundária (média de duração da doença de aproximadamente 14 anos), mostram resultados controversos. O primeiro estudo utilizou infusões autólogas de CTMs intratecal e o segundo, intravenosa. Embora o primeiro trabalho tenha relatado diminuição dos escores de atividade da doença, foram observadas novas lesões gadolíneo positivas e progressão da doença em 50\% dos pacientes (YAMOUT et al., 2010). Já o segundo estudo mostrou melhora da acuidade visual, aumento da área do nervo óptico e redução no volume de lesões cerebrais (CONNICK et al., 2012). Os autores não avaliaram parâmetros imunológicos, mas sugerem que mecanismos centrais e periféricos, que incluem imunorregulação, modificação do microambiente celular com liberação de fatores tróficos e anti-inflamatórios seriam responsáveis pelos efeitos de neuroproteção, reparação endógena e remielinização nesses pacientes (CONNICK et al., 2012).

Liang e colaboradores (2009) utilizaram CTMs alogênicas isoladas de cordão umbilical no tratamento de uma paciente com EM progressiva primária. Foram feitas infusões intratecal, intravenosa e pré-condicionamento com ciclofosfamida (600mg/3 dias). A paciente mostrou diminuição da atividade da doença após 6 meses e diminuição significativa das lesões cerebrais, especialmente na medula cervical, correlacionando-se com a estabilização clínica da doença.

Vários estudos de fase I/II em outras doenças autoimunes e neurológicas como esclerose lateral amiotrófica (MAZZINI et al., 2006; KARUSSIS et al., 2010; MAZZINI et al., 2010; UCCELLI \& FREEDMAN, 2011), isquemia cerebral (BANG et al., 2005) e lesões da medula espinhal (PAL et al., 2009; RA et al., 2010) têm sido realizados utilizando células autólogas e com resultados seguros, mas ainda não se sabe os mecanismos de ação desta intervenção nesses pacientes e se a fonte autóloga seria a opção mais adequada (UCCELLI \& FREEDMAN, 2011).

Concluindo, o racional para utilização das CTMs em doenças autoimunes baseia-se nos seus efeitos imunomoduladores sistêmicos (periféricos) e locais (no SNC), liberando fatores tróficos e anti-inflamatórios. Além disso, as vantagens da utilização das CTMs compreendem o seu fácil isolamento da medula óssea e outros tecidos adultos, fácil cultivo e expansão em grande escala in vitro. Os transplantes autólogos seriam seguros por não necessitarem de imunossupressão, e ainda, as células-tronco adultas parecem menos propensas a anormalidades genéticas e transformação maligna quando cultivadas por diversas passagens (KARUSSIS et al., 2010). 


\subsection{HIPÓTESES E JUSTIFICATIVA DO ESTUDO}

Embora as CTHs e CTMs já estejam sendo utilizadas em transplantes autólogos, não se sabe se essas células isoladas de pacientes com doenças autoimunes são genética ou funcionalmente semelhantes às células isoladas de indivíduos saudáveis. Pacientes com lúpus eritematoso sistêmico ou com artrite reumatóide apresentam reserva alterada de CTHs (em número e função) e função defeituosa de células estromais (PAPADAKI et al., 2002), não sendo definidas se essas alterações são intrínsecas das células-tronco, podendo ter papel importante na falha terapêutica em transplantes, ou ainda, se são causadas pelo processo inflamatório no microambiente medular.

Uma vez que as CTHs sejam precursoras de todas as subpopulações celulares do sistema imune, fizemos as seguintes hipóteses: i) as assinaturas de hibridação das CTHs de pacientes com EM são diferentes daquelas observadas em indivíduos sadios, ii) existem alterações em vias de sinalização que participam dos processos de diferenciação de linfócitos e tolerância imunológica. Além disso, considerando que as CTMs possuam funções importantes no nicho hematopoético, além de propriedades de imunossupressão e imunorregulação in vitro e in vivo, aventamos as hipóteses de que: i) os perfis de expressão de CTMs de pacientes com EM sejam diferentes dos perfis de CTMs obtidas de indivíduos saudáveis, ii) o transplante autólogo de CTHs pode recuperar o perfil de expressão gênica nas CTMs a patamares mais próximos aos observados em indivíduos saudáveis, iii) existem alterações em vias de sinalização que participam dos processos de imunossupressão/imunorregulação e iv) a atividade imunossupressora das CTMs de pacientes com EM é diferente da de indivíduos saudáveis.

Para testar essas hipóteses, avaliamos: i) os perfis de expressão gênica diferencial de células-tronco hematopoéticas e estromais mesenquimais isoladas da medula óssea de pacientes com EM e de indivíduos saudáveis; ii) o efeito da terapia de imunossupressão seguida pelo transplante autólogo de CTHs sobre a expressão gênica das CTMs, pela comparação do perfil de expressão gênica das amostras celulares isoladas pré- e póstransplante e, iii) a capacidade imunossupressora e imunorreguladora das CTMs de pacientes com EM e doadores saudáveis em ensaios de cocultivo com linfócitos alogênicos.

A identificação de defeitos funcionais nas CTHs e CTMs de pacientes com EM pode estar relacionada com o desencadeamento da autoimunidade ou falha do potencial terapêutico dessas células. 


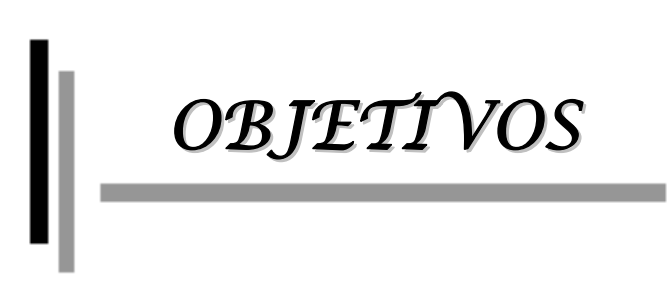




\section{OBJETIVOS}

\subsection{GERAL}

Avaliar os perfis de expressão gênica diferencial de células-tronco hematopoéticas e estromais mesenquimais isoladas de pacientes com esclerose múltipla antes e após o transplante autólogo de células-tronco hematopoéticas.

\subsection{ESPECÍFICOS}

1. Isolar e caracterizar por imunofenotipagem as células-tronco hematopoéticas $\operatorname{CD} 34^{+}$da medula óssea de pacientes com EM e de doadores saudáveis;

2. Isolar e expandir células estromais mesenquimais multipotentes da medula óssea de pacientes com EM e de doadores saudáveis e caracterizá-las quanto à morfologia, marcadores imunofenotípicos e capacidade de diferenciação multipotencial in vitro;

3. Avaliar o perfil de expressão gênica diferencial por microarrays de células-tronco hematopoéticas e estromais mesenquimais isoladas da medula óssea de pacientes com EM e de doadores saudáveis;

4. Avaliar o efeito da terapia de imunossupressão seguida do TACTH sobre a expressão gênica de células estromais mesenquimais de pacientes com EM, comparando o perfil de expressão gênica das amostras antes e após o transplante;

5. Análise in silico de processos biológicos significantes e vias de sinalização alteradas nas células-tronco hematopoéticas e estromais mesenquimais isoladas da medula óssea de pacientes com EM e de doadores saudáveis;

6. Estudar a capacidade de inibição da proliferação de linfócitos alogênicos pelas células estromais mesenquimais isoladas da medula óssea de pacientes com EM pré- e pósTACTH e de doadores saudáveis;

7. Avaliar o fenótipo e frequência de subpopulações linfocitárias após o cocultivo com células estromais mesenquimais isoladas da medula óssea de pacientes com EM pré- e pós-TACTH e de doadores saudáveis;

8. Determinar o perfil de citocinas nos cocultivos de células estromais mesenquimais, isoladas de pacientes com EM pré- e pós-TACTH e de doadores saudáveis, com linfócitos alogênicos. 
CASUÍSTICA E MÉTODOS 


\section{CASUÍSTICA E MÉTODOS}

\subsection{PACIENTES E CONTROLES}

Foram incluídos neste estudo 44 pacientes com EM (29 mulheres), com idades entre 20 a 55 anos (média de 37,2 \pm 9,4 anos), sendo 24 brancos e 20 mulatos, submetidos à terapia de imunossupressão com altas doses de ciclofosfamida, seguida do transplante autólogo de células-tronco hematopoéticas (TACTH), na Unidade de Transplante de Medula Óssea (TMO) do Hospital das Clínicas da Faculdade de Medicina de Ribeirão Preto (HCFMRP-USP), no período de setembro de 2004 a dezembro de 2011.

O protocolo do transplante específico para os pacientes com EM foi aprovado pelo Comitê de Ética em Pesquisa (CEP) do HCFMRP-USP (Processo $n^{\circ}$ 2693/2001) e pela Comissão Nacional de Ética em Pesquisa (CONEP) (RG $\left.n^{\circ} 2944\right)$. O presente trabalho foi aprovado pelo CEP do HCFMRP-USP (Processo no 2596/2009) (Anexo I). Pacientes e doadores saudáveis assinaram o termo de consentimento livre e esclarecido antes da doação.

Nos protocolos do projeto clínico, estão definidos os critérios de seleção dos pacientes com EM para realização do transplante que incluíam: i) idade entre 18 e 60 anos, ii) diagnóstico clínico estabelecido de EM de acordo com os critérios de Poser e colaboradores (1983), iii) presença de imagens típicas de EM detectadas por ressonância magnética nuclear (RMN), iv) pacientes com EM de evolução progressiva (formas progressiva secundária, progressiva primária ou surto-remissiva) (LUBLIN \& REINGOLD, 1996), iv) duração da doença superior ou igual a um ano, v) resposta insatisfatória às terapias convencionais (IFN- $\beta$ e pulsoterapia com corticosteróides), vi) EDSS (Expanded Disability Status Score) entre 3,0 e 6,5, progressão das incapacidades mantida por pelo menos seis meses nos últimos dois anos e elevação de 1,5 ponto no EDSS (quando o inicial estava entre 3,0 e 5,0 ) ou de 1,0 ponto ou mais, se o EDSS inicial era $\geq 5,5$. O EDSS constitui escala de medida da incapacidade, ou seja, avaliação das condições neurológicas do paciente, que varia de 0 (exame neurológico normal) a 10 (óbito). O aumento de 1,0 ou mais pontos na escala EDSS em dois exames repetidos, em intervalo mínimo de três meses, caracteriza progressão neurológica da EM. Por outro lado, a diminuição de 1,0 ou mais pontos na escala EDSS em dois exames repetidos, em intervalo mínimo de três meses, caracteriza melhora e consequente remissão da doença.

As avaliações clínicas realizadas no período anterior ao transplante indicaram que 35 pacientes apresentavam a forma progressiva secundária (PS), seis a forma surtoremissiva (SR) e três indivíduos a forma progressiva primária. O tempo de doença, ou seja, a data do primeiro surto até a última data da avaliação neurológica variou de quatro a 20 
anos de doença. Os valores de EDSS variaram de 3,0 a 6,5 (mediana $=6,0$ ) e foram observadas lesões ativas por imagens de ressonância magnética (gadolíneo positivas) em 10 dos pacientes avaliados (Tabela 1). A resposta clínica dos pacientes com EM ao TACTH foi avaliada pela frequência e intensidade de recaídas clínicas observadas pelo exame neurológico, ou seja, pelos valores de EDSS e pelo número e volume de lesões ativas observadas por imagens de ressonância magnética nuclear (Tabela 2).

O grupo de doadores saudáveis foi constituído por 29 indivíduos (16 mulheres), incluídos na faixa etária de 19 a 55 anos (média de 33,8 \pm 10). Para as avaliações dos perfis de expressãop gênica diferencial das CTHs foram avaliados 4 doadores, todos homens, apresentando média de idade de 33,5 anos. Para as avaliações dos perfis de expressão gênica diferencial das CTMs foram também avaliados 4 doadores ( 3 homens), com média de idade de 31 anos. Para os ensaios de inibição da proliferação de linfócitos e imunorregulação, foram utilizadas amostras de 16 doadores saudáveis (8 mulheres) com média de idade de 32,7 anos. 
Tabela 1: Características clínico-demográficas dos pacientes com esclerose múltipla (EM) no período anterior ao transplante autólogo de células tronco hemtopoéticas (TACTH).

\begin{tabular}{|c|c|c|c|c|c|c|}
\hline Paciente & $\begin{array}{l}\text { Sexol } \\
\text { idade } \\
\text { (anos) } \\
\end{array}$ & $\begin{array}{c}\text { Cor da } \\
\text { pele }\end{array}$ & $\begin{array}{l}\text { Forma } \\
\text { clínica }\end{array}$ & $\begin{array}{c}\text { Tempo de } \\
\text { doença } \\
\text { (anos) }\end{array}$ & $\begin{array}{l}\text { EDSS pré- } \\
\text { TACTH }\end{array}$ & $\begin{array}{l}\text { RMN pré- } \\
\text { TACTH }\end{array}$ \\
\hline EM01 & $\mathrm{M} / 52$ & Branco & PP & ND & 6,5 & Gd- \\
\hline EM02 & $\mathrm{F} / 30$ & Branca & PS & ND & 6,5 & Gd- \\
\hline $\mathrm{EMO3}^{\S}$ & $F / 43$ & Branca & PS & $20 a$ & 6,5 & Gd- \\
\hline EM04 & $\mathrm{M} / 54$ & Branco & PS & $16 a$ & 6,5 & Gd- \\
\hline EM05 $5^{\S}$ & $F / 36$ & Mulata & PS & $20 a$ & 6,5 & Gd- \\
\hline EM06 & $F / 32$ & Mulata & PS & $13 a$ & 6,0 & Gd- \\
\hline EM07 $\$$ & $\mathrm{~F} / 42$ & Mulata & PS & $17 a$ & 6,0 & Gd- \\
\hline EM08 8 & $\mathrm{M} / 49$ & Branco & PP & $17 a$ & 6,5 & Gd- \\
\hline EM09§ & $M / 29$ & Mulato & PS & ND & 6,0 & $\mathrm{Gd+}$ \\
\hline EM13 & $F / 36$ & Branca & PS & $18 a$ & 5,0 & Gd- \\
\hline EM14 & $\mathrm{M} / 33$ & Branco & PS & $17 a$ & 6,5 & $\mathrm{Gd}+$ \\
\hline EM15 $5^{\S}$ & $F / 31$ & Branca & PS & $12 a$ & 6,5 & $\mathrm{Gd+}$ \\
\hline EM16 & $\mathrm{M} / 40$ & Mulato & PS & $10 a$ & 5,5 & $\mathrm{Gd}+$ \\
\hline EM17* & $F / 42$ & Mulata & PS & $12 a$ & 6,5 & $\mathrm{Gd+}$ \\
\hline EM18 & $\mathrm{M} / 49$ & Branco & SR & $20 a$ & 3,0 & Gd- \\
\hline EM19 ${ }^{\S *}$ & $F / 32$ & Mulata & PS & $13 a$ & 6,0 & Gd- \\
\hline EM20 & $F / 38$ & Branca & SR & $7 a$ & 4,5 & Gd- \\
\hline EM21 & $\mathrm{M} / 55$ & Branco & PS & $18 a$ & 3,5 & Gd- \\
\hline EM22 & $\mathrm{M} / 49$ & Mulato & SR & $11 a$ & 4,0 & Gd- \\
\hline EM24 ${ }^{\S *}$ & $F / 41$ & Branca & PS & $16 a$ & 6,5 & Gd- \\
\hline EM25 & $\mathrm{M} / 43$ & Mulato & PS & $9 a$ & 6,0 & Gd- \\
\hline EM26* & $\mathrm{M} / 45$ & Branco & PS & $15 a$ & 5,5 & Gd- \\
\hline EM27 & $F / 41$ & Mulata & SR & $8 a$ & 3,0 & Gd- \\
\hline EM28 & $\mathrm{M} / 44$ & Branco & PS & $14 a$ & 6,5 & Gd- \\
\hline EM29 & $F / 22$ & Mulata & SR & $9 a$ & 3,0 & Gd- \\
\hline EM30 & $F / 26$ & Mulata & PS & $9 a$ & 6,5 & Gd- \\
\hline EM31 & $F / 33$ & Mulata & PS & $20 a$ & 6,5 & Gd- \\
\hline EM32 & $F / 48$ & Branca & PS & $11 a$ & 6,0 & Gd- \\
\hline EM33 & $F / 39$ & Branca & PS & $10 a$ & 6,5 & $\mathrm{Gd}+$ \\
\hline EM34* & $\mathrm{F} / 20$ & Branca & PS & $13 a$ & 5,5 & Gd- \\
\hline EM35 & $F / 21$ & Mulata & PS & $11 a$ & 6,0 & Gd- \\
\hline EM37 & $\mathrm{F} / 43$ & Mulata & PS & $15 a$ & 5,0 & $\mathrm{Gd}+$ \\
\hline EM38* & $F / 24$ & Mulata & PS & $9 a$ & 7,0 & Gd- \\
\hline EM41 & $M / 21$ & Branco & PS & $6 a$ & 6,0 & Gd- \\
\hline EM44 & $F / 36$ & Mulata & PS & $14 a$ & 6,5 & Gd- \\
\hline EM53 & $\mathrm{F} / 30$ & Mulata & PS & $9 a$ & 5,5 & Gd- \\
\hline EM56 & $\mathrm{F} / 30$ & Branca & PS & $19 a$ & 6,0 & $\mathrm{Gd}+$ \\
\hline EM59 & $\mathrm{F} / 27$ & Branca & PS & $7 a$ & 6,0 & $\mathrm{Gd+}$ \\
\hline EM60* & $F / 43$ & Branca & PS & $7 a$ & 6,5 & Gd- \\
\hline EM63* & $\mathrm{M} / 27$ & Mulato & SR & $6 a$ & 4,0 & $\mathrm{Gd+}$ \\
\hline EM65 & $F / 48$ & Branca & PS & $12 a$ & 5,0 & Gd- \\
\hline EM67* & $\mathrm{M} / 39$ & Branco & PP & $4 a$ & 4,0 & Gd- \\
\hline EM69 & $\mathrm{F} / 47$ & Branca & PS & $7 a$ & 6,0 & Gd- \\
\hline EM70 & $\mathrm{F} / 31$ & Mulata & PS & ND & 6,0 & Gd- \\
\hline
\end{tabular}

M: sexo masculino; F: sexo feminino; SR: surto-remissiva; PP: progressiva primária; PS: progressiva secundária; EDSS: Expanded Disability Status Score; RMN: ressonância magnética nuclear; Gd+: gadolíneo positivas, presença de lesões de atividade; ND: não determinado. Pacientes utilizados nos experimentos de microarrays (§) e cocultivo $(*)$. 
Tabela 2: Avaliação neurológica e resposta clínica dos pacientes com esclerose múltipla (EM) após o transplante autólogo de células-tronco hematopoéticas (TACTH).

\begin{tabular}{|c|c|c|c|c|}
\hline Paciente & $\begin{array}{l}\text { EDSS D+180 } \\
\text { pós-TACTH }\end{array}$ & $\begin{array}{l}\text { Último EDSS } \\
\text { pós-TACTH }\end{array}$ & $\begin{array}{l}\text { RMN D+180 } \\
\text { pós-TACTH }\end{array}$ & $\begin{array}{c}\text { Resposta clínica } \\
\text { pós-TACTH }\end{array}$ \\
\hline EM01 & 6,5 & $7,5(4 a)$ & Gd- & Progressão \\
\hline EM02 & ND & ND & ND & Óbito \\
\hline $\mathrm{EMO3}^{\S}$ & 6,5 & $7,0(6 a)$ & Gd- & Estabilização \\
\hline EM04 & 6,5 & $6,0(6 a)$ & Gd- & Estabilização \\
\hline EM05 & 6,5 & $9,5(4 a)$ & Gd- & Progressão \\
\hline EM06 & 6,0 & $6,0(5 a)$ & Gd- & Estabilização \\
\hline EM07 & 6,0 & $6,0(6 a)$ & Gd- & Estabilização \\
\hline EM08* & 6,5 & 7,5 (6a) & Gd- & Progressão \\
\hline EM09 & ND & ND & ND & ND \\
\hline EM13 & 2,5 & $2,5(4 a)$ & Gd- & Remissão clínica \\
\hline EM14 & 6,5 & $7,5(5 a)$ & Gd- & Progressão \\
\hline EM15 & 5,5 & $6,0(5 a)$ & Gd- & Estabilização \\
\hline EM16 & 5,0 & $4,5(5 a)$ & Gd- & Remissão clínica \\
\hline EM17 & 6,0 & $6,0(5 a)$ & Gd- & Estabilização \\
\hline EM18* & 4,5 & $4,0(5 a)$ & Gd- & Progressão \\
\hline EM19§ & 6,0 & $6,5(5 a)$ & Gd- & Estabilização \\
\hline EM20 & 4,5 & $4,5(1 a)$ & Gd- & Estabilização \\
\hline EM21 & 6,0 & $5,0(4 a)$ & Gd- & Progressão \\
\hline EM22* & 4,0 & $4,0(5 a)$ & Gd- & Estabilização \\
\hline EM24 & 6,5 & $6,5(4 a)$ & Gd- & Estabilização \\
\hline EM25* & 4,5 & $4,5(4 a)$ & Gd- & Remissão clínica \\
\hline EM26 & 5,0 & $5,5(4 a)$ & Gd- & Estabilização \\
\hline EM27* & 3,0 & $3,0(5 a)$ & Gd- & Estabilização \\
\hline EM28 & 7,0 & $7,0(4 a)$ & Gd- & Estabilização \\
\hline EM29 & 3,0 & $3,0(1 a)$ & Gd- & Estabilização \\
\hline EM30 & 6,5 & $6,5(4 a)$ & Gd- & Estabilização \\
\hline EM31 & 6,5 & $7,0(4 a)$ & Gd- & Estabilização \\
\hline EM32 & 4,0 & $5,0(4 a)$ & Gd- & Remissão clínica \\
\hline EM33 & 6,5 & $7,0(3 a)$ & Gd- & Estabilização \\
\hline EM34* & 3,5 & $3,5(3 a)$ & Gd- & Remissão clínica \\
\hline EM35 & 6,0 & $6,0(2 a)$ & Gd- & Estabilização \\
\hline EM37 & 5,5 & $6,0(3 a)$ & Gd- & Progressão \\
\hline EM38 & 7,5 & $7,5(3 a)$ & Gd- & Estabilização \\
\hline EM41 & 4,5 & $4,5(6 \mathrm{~m})$ & Gd- & Remissão clínica \\
\hline EM44 & 6,5 & $6,5(3 a)$ & Gd- & Estabilização \\
\hline EM53* & 4,5 & $5,0(2 a)$ & $\mathrm{Gd+}$ & Estabilização \\
\hline EM56* & 6,0 & $6,0(2 a)$ & Gd- & Estabilização \\
\hline EM59 & 6,0 & $6,0(1 a)$ & Gd- & Estabilização \\
\hline EM60 & ND & ND & ND & ND \\
\hline EM63 & 4,0 & $4,0(1 a)$ & Gd- & Estabilização \\
\hline EM65 & 5,5 & $4,5(1 \mathrm{a})$ & Gd- & Estabilização \\
\hline EM67 & 4,0 & $4,0(1 a)$ & Gd- & Estabilização \\
\hline EM69 & 6,0 & $6,0(6 \mathrm{~m})$ & Gd- & Estabilização \\
\hline EM70* & ND & ND & ND & ND \\
\hline
\end{tabular}

EDSS: Expanded Disability Status Score; RMN: ressonância magnética nuclear; Gd-: gadolíneo negativas, ausência de lesões de atividade; $\mathrm{Gd}+$ : presença de lesões de atividade, gadolíneo positivas; ND: não determinado. Pacientes utilizados nos experimentos de microarrays (§) e cocultivo $(*)$. 


\subsection{TRANSPLANTE AUTÓLOGO DE CÉLULAS-TRONCO HEMATOPOÉTICAS}

O esquema da terapia de imunossupressão seguida do transplante autólogo de células-tronco hematopoéticas (TACTH) foi constituído por quatro etapas: i) fase de mobilização das CTHs para o sangue periférico, ii) fase de condicionamento, constituída pela administração da droga imunossupressora, iii) fase de infusão das CTHs autólogas ou, transplante propriamente dito, e iv) fase de seguimento dos pacientes nos períodos póstransplante.

\subsubsection{MOBILIZAÇÃO DAS CÉLULAS-TRONCO HEMATOPOÉTICAS}

As CTHs foram mobilizadas da medula óssea para o sangue periférico, utilizando ciclofosfamida $\left(2 \mathrm{~g} / \mathrm{m}^{2}\right)$ e fator estimulador de colônias granulocíticas (G-CSF) (10 $\mu \mathrm{g} / \mathrm{Kg} / \mathrm{dia})$. O início da coleta foi determinado pela contagem de leucócitos e de células $\mathrm{CD}^{+} 4^{+}$no sangue periférico: leucócitos $>1000 / \mathrm{mm}^{3}$ e células CD34 ${ }^{+}>10$ células $/ \mathrm{mm}^{3}$. A aférese foi realizada uma ou duas vezes até atingir o valor mínimo de $3,0 \times 10^{6} \mathrm{CD} 34^{+} / \mathrm{kg}$ de peso. Foram colhidas entre 3,4 e 25,1 x $10^{6}$ células CD34 $/ \mathrm{kg}$ (média $8,5 \times 10^{6} / \mathrm{kg}$ ) dos pacientes com EM. Após a coleta, as CTHs autólogas foram criopreservadas e armazenadas em nitrogênio líquido até o momento do transplante.

\subsubsection{FASE DE CONDICIONAMENTO}

A fase de condicionamento foi constituída pela administração da droga imunossupressora para depleção in vivo de linfócitos B e T nos pacientes. Os dois primeiros pacientes (EM01 e EM02) receberam regime de condicionamento constituído de poliquimioterapia denominada BEAM (BiCNU®, etoposídeo, citarabina e melfalan), associado à globulina antitimocitária (ATG) de cavalo $(6 \times 15 \mathrm{mg} / \mathrm{kg} / \mathrm{dia})$. Os demais pacientes com EM receberam ciclofosfamida $(4 \times 50 \mathrm{mg} / \mathrm{Kg} / \mathrm{dia})$ e globulina ATG de coelho (4,5 mg/Kg/dia).

\subsubsection{INFUSÃO DAS CÉLULAS-TRONCO HEMATOPOÉTICAS}

A infusão das CTHs ocorreu no dia zero, data em que o transplante foi realizado. Foram administrados G-CSF ( $5 \mu \mathrm{g} / \mathrm{Kg} / \mathrm{dia})$ no dia +5 até o dia no qual a contagem de neutrófilos atingisse valor $>1000 / \mathrm{mm}^{3}$. Na maioria dos pacientes, foi infundida a quantidade total de células CD $34^{+}$coletadas. 


\subsubsection{SEGUIMENTO DO PACIENTE APÓS O TRANSPLANTE}

Os pacientes permaneceram internados na Unidade de TMO do HCFMRP-USP até a enxertia e em seguimento ambulatorial intensivo no Hospital-Dia até aproximadamente 60 dias após o transplante. Após esse período, os pacientes retornaram às suas residências e compareceram a consultas periódicas de acompanhamento no ambulatório da Unidade de TMO do HCFMRP-USP.

\subsection{ISOLAMENTO DE CÉLULAS MONONUCLEARES DA MEDULA ÓSSEA}

Amostras de 3-5 $\mathrm{mL}$ de punção de medula óssea dos pacientes com EM nos períodos pré-transplante e $\mathrm{D}+180$ pós-TACTH e dos doadores saudáveis foram colhidas na presença de EDTA, e separadas por centrifugação em gradiente de densidade (BOYUM, 1974) (Ficoll-Hypaque ${ }^{\mathrm{TM}} \mathrm{d}=1,077$, Amersham-Pharmacia, Uppsala, Suécia). As amostras foram diluídas 1:2 em tampão fosfato, contendo anticoagulante (PBS-ACD), aplicadas cuidadosamente sobre o Ficoll-Hypaque, e centrifugadas a $500 \mathrm{~g}$ por 30 minutos à temperatura ambiente (TA) para obtenção da camada de células mononucleares. As células presentes na interface plasma-Ficoll-Hypaque foram cuidadosamente coletadas, lavadas duas vezes com PBS-ACD, ressuspensas em meio RPMI 1640 (GIBCO BRL Life Technologies, Grand Island, NY, EUA), contendo 10\% soro fetal bovino (SBF), e contadas em câmara de Neubauer. Após a contagem de células, essas foram utilizadas para isolamento de células-tronco hematopoéticas por coluna imunomagnética e/ou plaqueadas para isolamento e cultura de células estromais mesenquimais.

Para a realização de todos os ensaios de caracterização, as células foram expandidas até a terceira passagem para a seleção de população homogênea de CTMs, sem contaminação por células da medula óssea (blastos, células-tronco hematopoéticas, monócitos e células endoteliais). Durante as culturas celulares, foram congeladas em nitrogênio líquido alíquotas de CTMs de todas as passagens para que pudessem ser descongeladas e expandidas para ensaios posteriores.

\subsection{SEPARAÇÃO IMUNOMAGNÉTICA DE CÉLULAS-TRONCO HEMATOPOÉTICAS}

Após a separação das células mononucleares da medula óssea por centrifugação em gradiente de densidade, as $\mathrm{CTH}$ s $\mathrm{CD} 34^{+}$foram isoladas por coluna imunomagnética utilizando-se o kit comercial CD34 Progenitor Cell Isolation (MACS; Miltenyi Biotec, Bergisch Gladbach, Alemanha). A uma suspensão celular de até $3 \times 10^{8}$ células $/ 300 \mu \mathrm{L}$ de PBS-EB (PBS, $2 \mathrm{mM}$ EDTA, 0,5\% soro albumina humana) foram adicionados $100 \mu \mathrm{L}$ de FcR Blocking Reagent e $100 \mu \mathrm{L}$ de Hapten-Antibody, e as células foram incubadas por 15 
minutos a $4^{\circ} \mathrm{C}$, e, em seguida, lavadas com PBS-EB gelado. As células foram ressuspensas em $400 \mu \mathrm{L}$ de PBS-EB e incubadas com $100 \mu \mathrm{L}$ de Anti-hapten Microbeads por 15 minutos a $4^{\circ} \mathrm{C}$, e, em seguida, lavadas com PBS-EB gelado e ressuspensas nesse tampão. A suspensão celular foi então adicionada na coluna separadora presa a um campo magnético. As CTHs foram isoladas por seleção positiva, ou seja, as células CD34+ magneticamente marcadas ficam retidas na coluna, enquanto que, as não marcadas passam por ela. Em seguida, a coluna foi lavada com PBS-EB, removida do campo magnético e as células $\mathrm{CD}^{+} 4^{+}$marcadas eluídas com PBS-EB. Uma amostra das células CD $34^{+}$foi analisada por citometria de fluxo para análise da porcentagem de pureza, e ao restante das células foi adicionado solução de Trizol. Essas amostras foram congeladas a $-80^{\circ} \mathrm{C}$ até o momento da extração de RNA. Para os experimentos de expressão gênica diferencial por microarrays foram utilizadas amostras com pureza de células CD $34^{+}$igual ou superior a $80 \%$.

\subsection{ISOLAMENTO E CULTURA DE CÉLULAS ESTROMAIS MESENQUIMAIS}

Após a separação das células mononucleares da medula óssea por centrifugação em gradiente de densidade, $1-4 \times 10^{7}$ células foram suspensas em meio de cultura $\alpha$-MEM (Gibco) com $15 \%$ de SBF, plaqueadas em garrafa de $75 \mathrm{~cm}^{2}$, e cultivadas a $37^{\circ} \mathrm{C}$ com $5 \%$ de $\mathrm{CO}_{2}$. Após sete dias, as células não aderentes foram removidas e foram adicionados 20 $\mathrm{mL}$ de meio de cultura $\alpha$-MEM. O meio de cultura foi trocado a cada três dias e quando as células estavam semiconfluentes, foram tripsinizadas (tripsina 1\%, Sigma, Saint Louis, EUA) e repicadas para outras garrafas (primeira passagem). As células foram repicadas mais uma vez (segunda passagem) e na terceira passagem, foram separadas alíquotas de CTMs para caracterização imunofenotípica por citometria de fluxo, caracterização do potencial de diferenciação multipotencial, ensaios de cocultivo com linfócitos e para congelamento em Trizol para posterior extração de RNA e análise da expressão gênica diferencial por microarrays.

\subsection{CARACTERIZAÇÃO IMUNOFENOTÍPICA DE CÉLULAS ESTROMAIS MESENQUIMAIS}

Alíquotas de $100 \mu \mathrm{L}\left(0,1 \times 10^{6}\right.$ células $\left./ \mathrm{mL}\right)$ de CTMs isoladas de doadores saudáveis $(\mathrm{N}=28)$ e de pacientes com EM pré- $(\mathrm{N}=32)$ e pós-TACTH $(\mathrm{N}=24)$ foram incubadas por 15 minutos, à TA, no escuro, com $5 \mu \mathrm{L}$ de anticorpos monoclonais ou isotipos controles diretamente conjugados a fluorocromos, isotiocianato de fluoresceína (FITC) ou ficoeritrina (PE). Foram feitas marcações simples ou duplas para a análise dos diversos marcadores. Após a incubação, as células foram lavadas com tampão PBS $1 \mathrm{X}$ e centrifugadas por 5 minutos a $500 \mathrm{~g}$, ressuspensas em $200 \mu \mathrm{L}$ de PBS e analisadas no citômetro de fluxo 
FACSort (Becton-Dickinson, San Jose, CA, EUA). Foram adquiridos 20.000 eventos/amostra com base nos parâmetros de tamanho (FSC) e granularidade (SSC). As análises foram realizadas utilizando-se o software Cellquest (Becton-Dickson). Para a caracterização imunofenotípica das CTMs foram utilizados os anticorpos monoclonais para os seguintes marcadores: CD90-PE, CD13-APC, CD29-APC, CD105-APC, CD73-PE, CD44-FITC, CD166-PE, HLA-ABC-PE, CD146-FITC, CD54PE, CD106-FITC, HLA-DR-FITC, CD14-PE, CD31-FITC, CD34-APC e CD45-FITC (todos da Becton-Dickison).

\subsection{DIFERENCIAÇÃO MULTIPOTENCIAL DE CÉLULAS ESTROMAIS MESENQUIMAIS}

$\mathrm{Na}$ terceira passagem, as CTMs de dadores saudáveis $(\mathrm{N}=8)$ e de pacientes com EM $(\mathrm{N}=8)$ foram induzidas à diferenciação em adipócitos e osteócitos pelo cultivo em meios específicos. Alíquotas de $1 \mathrm{~mL}$, contendo 4.000 células $/ \mathrm{mL}$, foram cultivadas em placas de 24 poços com lamínulas para a realização de estudos morfológicos. A diferenciação foi iniciada no mínimo 24 horas após o início do cultivo, quando a aderência e confluência estavam em torno de $50 \%$. Nessa ocasião, todo o meio de cultura foi removido e foi adicionado $1 \mathrm{~mL}$ de meio de indução (adipócitos ou osteócitos) ou somente o meio $\alpha$-MEM $7,5 \%$ SFB como controle. As placas foram incubadas a $37^{\circ} \mathrm{C}$ com $5 \%$ de $\mathrm{CO}_{2}$ e metade do meio foi trocado duas vezes por semana. O meio utilizado para troca continha o dobro da concentração dos agentes indutores. As células foram cultivadas a $37^{\circ} \mathrm{C} \operatorname{com} 5 \%$ de $\mathrm{CO}_{2}$ até a diferenciação celular e monitoradas sob microscopia invertida. Para diferenciação em adipócitos, foi utilizado meio a-MEM 15\% SBF, suplementado com $10 \mu \mathrm{M}$ de dexametasona (Decadron injetável, Prodome, Campinas/SP, Brasil), $10 \mu \mathrm{g} / \mathrm{mL}$ de insulina (Sigma) e 100 $\mathrm{mM}$ de indometacina (Sigma). Para diferenciação em osteócitos foi utilizado meio $\alpha$-MEM $7,5 \%$ SBF suplementado com $0,10 \mu \mathrm{M}$ de dexametasona, $100 \mu \mathrm{M}$ de ácido ascórbico e 10 $\mathrm{mM}$ de $\beta$-glicerolfosfato (Reagen, Colombo/PR, Brasil). Após a diferenciação, as células foram identificadas por coloração histoquímica: adipócitos (Sudan II-escarlate, Oil red, Sigma) e osteócitos (Von Kossa e fosfatase alcalina, Sigma). A análise da diferenciação e documentacao fotográfica foi realizada em microscópio Zeiss, modelo Axioshop 2.0 e as imagens capturadas com a câmera Axiocam, utilizando o software AxioVision 3.0 (Carl Zeiss, Germany).

\subsection{EXTRAÇÃO E PURIFICAÇÃO DE RNA TOTAL}

A extração do RNA total das CTHs e CTMs foi realizada pelo método do Trizol (Invitrogen LifeTechnologies, Carlsbad, CA, EUA) (CHOMCZYNSKI \& SACCHI, 1987). A uma suspensão de até $1,0 \times 10^{7}$ células ressuspensas em $200 \mu \mathrm{L}$ de solução fisiológica 
previamente tratada com dietilpirocarbonato (DEPC) foi adicionado $1 \mathrm{~mL}$ de Trizol. Essa solução foi homogeneizada e então incubada por cinco minutos à TA, para permitir completa dissociação de complexos de nucleoproteínas. Em seguida, foram adicionados $5 \mu \mathrm{L}$ de glicogênio $(20 \mu \mathrm{g} / \mathrm{mL}$, USB, Cleveland, Ohio, EUA) e $250 \mu \mathrm{L}$ de clorofórmio (Sigma) para cada $\mathrm{mL}$ de Trizol, seguido de agitação vigorosa por aproximadamente 15 segundos. $O$ material foi posteriormente incubado por 2 a 3 minutos à TA e centrifugado por 15 minutos a $12.000 \mathrm{~g}$ a $4^{\circ} \mathrm{C}$. Após essa centrifugação ocorre a separação da solução em três fases (aquosa, interface e orgânica). A fase aquosa foi transferida para um novo tubo contendo $500 \mu \mathrm{L}$ de isopropanol (Merck, Darmstadt, Alemanha) para cada $\mathrm{mL}$ de Trizol para precipitação do RNA. Esse tubo foi homogeneizado por inversão, seguido de incubação overnight a $-20^{\circ} \mathrm{C}$ e, então, centrifugado novamente a $12.000 \mathrm{~g}$ por 10 minutos a $4^{\circ} \mathrm{C}$. O sobrenadante foi removido e o pellet de RNA lavado com $1 \mathrm{~mL}$ de etanol $75 \%$, seguido de centrifugação a $7.500 \mathrm{~g}$ por 5 minutos a $4^{\circ} \mathrm{C}$. O RNA era secado por 10 minutos ou até total evaporação do etanol e era eluído em água RNase-free e armazenado a $-80^{\circ} \mathrm{C}$.

A purificação do RNA total foi realizada utilizando-se o RNeasy mini Kit (Qiagen, Valencia, CA, EUA). Anteriormente à purificação do RNA, foi realizada a digestão de DNases com adição de $10 \mu \mathrm{L}$ de tampão e $2,5 \mu \mathrm{L}$ de DNase I ao RNA diluído por um minuto à TA. Após essa etapa, foram adicionados $350 \mu \mathrm{L}$ de tampão e $250 \mu \mathrm{L}$ de etanol absoluto. As amostras foram homogenizadas por pipetagem e imediatamente transferidas para as colunas de purificação e centrifugadas a $8000 \mathrm{~g}$ por 15 segundos. Posteriormente, foram adicionados $500 \mu \mathrm{L}$ de tampão nas colunas por duas vezes, seguido de centrifugações de $8.000 \mathrm{~g}$ por 15 segundos e dois minutos, respectivamente. Após essas lavagens, o tubo coletor foi trocado e foi adicionada de $30-50 \mu \mathrm{L}$ de água RNase-free diretamente na coluna que foi centrifugada a $8.000 \mathrm{~g}$ por um minuto para eluição do RNA. A concentração final de RNA e a razão A260/A280 das amostras foi determinado por espectrofotômetro NanoDrop (ND-1000 UV-VIS, Thermo Fisher Scientific, Walthman, Massachusetts, EUA) e a integridade do RNA foi avaliada por eletroforese em gel de agarose. Os RNAs utilizados para estudo da expressão gênica por microarrays foram de excelente qualidade, visto pela razão A260/A280, que ficou entre 1,8-2,0. Foi utilizado $1 \mu \mathrm{g}$ de RNA total para realizar o processo de marcação com o kit One-color microarrays-based gene expression analysis (Agilent Technologies, Santa Clara, EUA).

\subsection{ANÁLISE DA EXPRESSÃO GÊNICA DIFERENCIAL POR MICROARRAYS}

O perfil de expressão gênica diferencial das CTHs e CTMs foi avaliado utilizando-se o sistema comercial One-color microarrays-based gene expression analysis, contendo 44.000 sondas $(4 \times 44 \mathrm{~K} \mathrm{~V} 2$, Agilent Technologies). Este sistema consiste na seguinte 
metodologia: $10 \eta g$ de poly(A)+ RNA ou $1 \mu \mathrm{L}$ de RNA total serviu de molde para a síntese da primeira fita de cDNA. A síntese da primeira fita do cDNA foi realizada por transcrição reversa utilizando um oligonucleotídeo de DNA contendo um sítio promotor da enzima T7 RNA polimerase. Em seguida, foi feita a síntese da segunda fita do cDNA, que serviu de molde para a reação de transcrição in vitro que produz o cRNA alvo marcado. A transcrição in vitro de cRNA foi amplificada, utilizando o Agilent's low RNA input linear amplification kit plus, que permite a incorporação do fluorocromo 3-cianina.

Após o tratamento com DNase e purificação com o RNeasy mini Kit, o cRNA amplificado foi quantificado usando o espectrofotômetro NanoDrop e foi calculada a concentração do fluorocromo 3-cianina ( $\mathrm{pmol} / \mu \mathrm{L})$, bem como a relação de absorbância em $260 \eta \mathrm{m} / 280 \eta \mathrm{m}$ e a concentração do cRNA $(\eta \mathrm{g} / \mu \mathrm{L})$. Foram utilizados cerca de 1,65 $\mu \mathrm{L}$ de cRNA ligado a 3-cianina de cada amostra para hibridação em lâminas, seguindo o protocolo do fabricante (Agilent microarrays hybridization chamber user guide). Os cRNAs amplificados e purificados foram fragmentados a $60^{\circ} \mathrm{C}$ por 30 minutos em buffer de hibridação, e, em seguida, hibridados nas lâminas de microarrays overnight a $65^{\circ} \mathrm{C}$ em incubadora sob agitação $(500 \mathrm{~g})$. Após a hibridação, foram realizadas lavagens estringentes com água destilada e desionizada para remover as moléculas não ligadas ou ligadas inespecificamente. Em seguida, os microarrays foram novamente lavados utilizando o wash buffer 1 e 2 e secos por centrifugação. As lâminas foram escaneadas utilizando o software GenePix Pro 6.0 e o scanner GenePix 4000B (Axon Instruments, Foster City, EUA) em três diferentes PMT (photon multiple transmission). As imagens foram obtidas no Agilent feature extraction software versão 9.5 .1 (Agilent Technologies) para posterior análise da expressão gênica diferencial.

\subsection{ENSAIO DE COCULTIVO DE CÉLULAS ESTROMAIS MESENQUIMAIS E LINFÓCITOS ALOGÊNICOS}

Para o ensaio de inibição da proliferação de linfócitos na presença de CTMs isoladas de doadores saudáveis $(\mathrm{N}=16)$ e de pacientes nos períodos pré- $(\mathrm{N}=10)$ e pósTACTH ( $\mathrm{N}=9$ ) foi utilizado o método de diluição com CFSE (carboxyfluorescein diacetate succinimidyl Ester, invitrogen) e avaliado por citometria de fluxo. As células mononucleares (CMNs) isoladas do sangue periférico de doadores sadios foram separadas por centrifugação em gradiente de densidade, marcadas com CFSE e ressuspensas em meio RPMI 1640 com $5 \%$ de soro humano $A B$ (concentração de $0,5 \times 10^{6}$ células $/ \mathrm{mL}$ ). As CMNs marcadas com CFSE foram adicionadas aos poços $(1 \mathrm{~mL} /$ poço) contendo as CTMs já aderidas previamente em 6 diferentes proporções (CTMs/CMNs - 1/2, 1/5, 1/10, 1/20, 1/50 e $1 / 100$ ) na presença de $0,5 \mu \mathrm{g} / \mathrm{mL}$ de fitohemaglutinina (PHA, Sigma). Foram feitos controles 
positivo e negativo do ensaio de proliferação: CMNs não-marcadas, CMNs marcadas com CFSE, CMNs marcadas com CFSE e estimuladas com PHA. As células foram cocultivadas por 5 dias a $37^{\circ} \mathrm{C}$ com $5 \% \mathrm{CO}_{2}$. No quinto dia de cocultivo, as $\mathrm{CMNs}$ foram colhidas, marcadas com anticorpo anti-CD3 conjugado a PE (Beckton-Dickson) e analisadas por citometria de fluxo para avaliação das porcentagens de proliferação.

Para os ensaios de imunorregulação, avaliamos o fenótipo e a frequência de algumas subpopulações linfocitárias recuperadas após os experimentos de cocultivo com as CTMs isoladas de doadores saudáveis e de pacientes com EM nos períodos pré- e póstransplante. Para tal, as CMNs isoladas do sangue periférico de doadores sadios foram separadas por centrifugação em gradiente de densidade, ressuspensas em meio RPMI 1640 com $5 \%$ de soro humano $A B$ (concentração de $0,5 \times 10^{6}$ células $/ \mathrm{mL}$ ) e adicionadas aos poços ( $1 \mathrm{~mL} /$ poço) contendo as CTMs previamente aderidas, na presença do mitógeno PHA $(0,5 \mu \mathrm{g} / \mathrm{mL})$. As células foram cocultivadas por 5 dias a $37^{\circ} \mathrm{C}$ com $5 \% \mathrm{CO}_{2}$. No quinto dia de cocultivo, as células foram colhidas e marcadas para as seguintes subpopulações: células $T$ $\mathrm{CD}^{+} \mathrm{CD} 4^{+}$e $\mathrm{CD}^{+} \mathrm{CD} 8^{+}, \mathrm{CD}^{+} \mathrm{NKT}^{+}, \mathrm{CD}^{+} \mathrm{CD} 25^{\mathrm{hi}}, \mathrm{CD} 4^{+} \mathrm{CD} 25^{\mathrm{hi}} \mathrm{FOXP} 3^{+}, \mathrm{CD} 4^{+} C D 25^{\mathrm{hi}} C T L A-$ $4^{+}, \quad \mathrm{CD}^{+}{ }^{+} \mathrm{CD} 25^{\mathrm{hi}} \mathrm{GITR}^{+}, \quad \mathrm{CD}^{+} \mathrm{CD}_{28}^{-}, \quad \mathrm{CD}^{+} \mathrm{CD}^{-} 8^{-} \mathrm{FOXP}^{+}, \quad \mathrm{CD}^{+} \mathrm{CD}^{+}{ }^{+} \mathrm{HLA}-\mathrm{G}^{+} \quad \mathrm{e}$ $\mathrm{CD}^{+} \mathrm{CD} 8^{+} \mathrm{HLA}-\mathrm{G}^{+}$e avaliadas por citometria de fluxo, utilizando anticorpos monoclonais (Becton-Dickinson ou Abcam, Cambridge, Reino Unido).

\subsection{QUANTIFICAÇÃO DE CITOCINAS NO SOBRENADANTE DOS COCULTIVOS}

As dosagens de citocinas no sobrenadante das coculturas de células estromais mesenquimais e linfócitos alogênicos foram realizadas pelos métodos CBA flex (Cytometric Bead Array, Becton-Dickson) e ELISA (HGF Human ELISA kit, invitrogen). Ao final dos cinco dias de cocultivo das CTMs com as células linfomononucleares, $500 \mu \mathrm{L}$ do sobrenadante dos poços controles (CTMs doadores saudáveis + $\mathrm{CMNs}+\mathrm{PHA}$ ) e dos poços contendo CTMs pacientes (pré- e pós-TACTH) + CMNs + PHA foram colhidos e congelados a $-80^{\circ} \mathrm{C}$ para posterior quantificação de citocinas. Primeiramente, preparou-se a curva colocando em um tubo de $15 \mathrm{~mL}$ todas as proteínas liofilizadas (IFN- $\gamma$, TNF, IL-1ß, IL-6, IL-10, IP-10 e TGF$\beta)$. Essas proteínas foram reconstituídas em $4 \mathrm{~mL}$ de assay diluent, homogeneizadas com uma pipeta gentilmente, preparando assim, uma solução top standard (ponto inicial da curva $2.500 \mathrm{pg} / \mathrm{mL}$ das proteínas). Esta solução top standard foi incubada por 15 minutos à TA e, posteriormente, as diluições da curva foram feitas a partir dela, constituindo os pontos 1:2 (1.250 pg/mL), 1:4 (625 pg/mL), 1:8 (312,5 pg/mL), 1:16 (156 pg/mL), 1:32 (80 pg/mL), 1:64 (40 pg/mL), 1:128 (20 pg/mL) e 1:256 (10 pg/mL).

Após a curva, preparou-se a diluição das beads de captura, agitando vigorosamente cada suspensão por 15 segundos antes de misturá-las. Foram adicionados 
$100 \mu \mathrm{L}$ de cada citocina (IFN- $\gamma, \mathrm{TNF}, \mathrm{IL}-1 \beta, \mathrm{IL}-6, \mathrm{IL}-10, \mathrm{IP}-10$ ) em um tubo de $15 \mathrm{~mL}$, completando o volume total de $5 \mathrm{~mL}$ com tampão Capture Bead Diluent. Após homogeneização, $50 \mu \mathrm{L}$ das soluções de citocinas foram acrescidos de $50 \mu \mathrm{L}$ do sobrenadante e a preparação foi incubada por uma hora à TA, protegida da luz. Em seguida, $50 \mu \mathrm{L}$ da suspensão de $P E$ detection eram adicionados e a preparação era incubada por duas horas à TA e protegida da luz. Posteriormente, as beads eram lavadas com $1 \mathrm{~mL}$ de tampão de lavagem e centrifugadas a $200 \mathrm{~g}$, por 5 minutos. O sobrenadante era descartado cuidadosamente e o pellet ressuspenso em $100 \mu \mathrm{L}$ de wash buffer. As leituras eram realizadas em citômetro de fluxo e analisadas com o auxílio do software FCAP array (BD).

A citocina TGF- $\beta$ foi quantificada separadamente, devido à necessidade de etapa de pré-ativação para a sua forma imunorreativa. Para ativação do TGF- $\beta$, as amostras foram acidificadas com $50 \mu \mathrm{L}$ de $\mathrm{HCl} 1 \mathrm{~N}$ e incubadas por 10 minutos à TA e depois neutralizadas com $50 \mu \mathrm{L}$ de $\mathrm{NaOH} / 0,5 \mathrm{M}$ Hepes $1,2 \mathrm{~N}$. Após ativação, as etapas subsequentes foram idênticas às descritas anteriormente para as outras citocinas.

A quantificação de HGF no sobrenadante das coculturas foi realizada por ELISA. Primeiramente, preparou-se a curva padrão com Standard Diluent Buffer com as seguintes duições do HGF 8,000 pg/mL, $4.000 \mathrm{pg} / \mathrm{mL}, 2.000 \mathrm{pg} / \mathrm{mL}, 1.000 \mathrm{pg} / \mathrm{mL}, 500 \mathrm{pg} / \mathrm{mL}, 250$ $\mathrm{pg} / \mathrm{mL}$ e $125 \mathrm{pg} / \mathrm{mL}$. Após o preparo da curva, foram adicionados $150 \mu \mathrm{L}$ de Incubation Buffer nos poços teste, excetuando-se o branco. Posteriormente, foram adicionados $50 \mu \mathrm{L}$ de Standard Diluent Buffer no ponto zero da curva $(0 \mathrm{pg} / \mathrm{mL})$ e $50 \mu \mathrm{L}$ das diluições da curva e das amostras teste, incubando-se por três horas à TA. Em seguida, os poços foram lavados quatro vezes com Wash Buffer e, após as lavagens, foram adicionados $100 \mu \mathrm{L}$ da solução Biotinylated anti-Human HGF em cada poço teste, com exceção do poço controle (branco), seguindo-se de uma incubação de uma hora à TA. Os poços foram lavados quatro vezes com Wash Buffer e, após as lavagens, foram adicionados $100 \mu \mathrm{L}$ de Streptavidin-HRP Working solution, com exceção do poço controle, seguido de uma incubação de 30 minutos à TA. Após essa incubação, os poços foram lavados novamente por quatro vezes com Wash Buffer, sendo então, adicionados $100 \mu \mathrm{L}$ de Stabilized Chromogen, seguido de uma incubação de 30 minutos à TA no escuro. Após, foram adicionados $100 \mu \mathrm{L}$ de Stop Solution em cada poço, que mudaram de coloração azul para amarela. A leitura foi realizada em espectrofotômetro a $450 \mathrm{~nm}$, sendo que a leitura do poço controle foi feita anteriormente aos poços contendo as amostras a serem testadas. Foi gerada uma curva padrão a partir das diluições seriadas e através da equação da reta foram estabelecidos valores de concentração do HGF em cada amostra testada. 


\subsection{ANÁLISE ESTATÍSTICA E DOS DADOS DE MICROARRAYS}

Para determinar as diferenças entre o imunofenótipo e a capacidade imunomoduladora das CTMs de pacientes e controles foram utilizadas as análises de variância One-way Anova com pós-teste de Dunnet ou Kruskal-Wallis com pós-teste de Dunn, dependendo da distribuição dos resultados obtidos. A correlação da capacidade de inibição da proliferação de linfócitos alogênicos com os valores de EDSS dos pacientes com EM foi realizada pela correlação de Pearson. Os testes foram realizados pelo programa estatístico GraphPad Prism, versão 5.0 (GraphPad Software, San Diego, EUA), sendo considerados significantes valores de $P<0,05$.

Os resultados de expressão gênica diferencial gerados pelas hibridações em lâminas de microarrays foram analisados na Plataforma $R$ (http://cran.r-project.org) no Laboratório de Genética Molecular e Bioinformática do Centro de Terapia Celular, Hemocentro de Ribeirão Preto (HCFMRP-USP).

No ambiente $R$, as etapas de pré-processamento dos dados, assim como as análises estatísticas subsequentes, foram conduzidas utilizando os algoritmos disponíveis no projeto Bioconductor (http://www.bioconductor.org/). Nessa etapa, o pacote de funções "Agi4x44PreProcess" foi utilizado para: i) anotação gênica das sondas, utilizando o pacote de funções "hgug4112a.db"; ii) transformação logarítmica dos sinais (log2); iii) correção do sinal de background com o algoritmo normexp (SILVER et al., 2009); iv) normalização entre as amostras de um mesmo grupo de pacientes utilizando o algoritmo quantile; v) filtragem de sondas com diferentes tipos de erros na captura do sinal ou consideradas outliers; vi) cáculos das intensidades de sinais das sondas replicadas, utilizando a mediana dos sinais; vii) remoção dos genes mapeados nos cromossomos sexuais e sondas não mapeadas em genes conhecidos.

Para determinar diferenças entre os grupos de CTHs e CTMs de pacientes e controles, todas as sondas foram selecionadas e submetidas a algorítmos de agrupamento hierárquico simples e um segundo agrupamento com 1.000 replicatas para obter um agrupamento consenso (WILKERSON \& HAYES, 2010). Os parâmetros utilizados nas análises incluíam distância euclidiana e o método de ligação média (Pairwise Average Linkage). A identificação dos genes diferencialmente expressos entre os grupos hierárquicos foi baseada nos valores de fold-change $\geq 2$ e significância estatística de $P$-valor $<0,01$, utilizando o pacote Linear Models for Microarray Data (LIMMA) (http://www.tm4.org/mev_manual/limma.html).

O enriquecimento funcional dos genes diferencialmente expressos nas CTHs e CTMs dos pacientes foi realizado pelo software DAVID (David Functional Annotation Bioinformatic Microarray Analysis 6.7, National Institute of Allergy and Infectious Diseases, 
NIH) (HUANG et al., 2009). O programa realiza agrupamentos de funções biológicas, com base no compartilhamento de genes comuns através de programas estatísticos (estatística Kappa e algoritmos de clusterização heurística Fuzzy). Nesse sentido, quanto maior o número de genes compartilhados, maior a chance do agrupamento de funções biológicas em um mesmo grupo. Os valores de $P$ associados a cada função biológica dentro de cada cluster são os valores de $P$ exatos de Fisher que representam o grau de significância de cada função com a lista de genes envolvidos em cada uma delas. Foram selecionadas somente categorias dos bancos internos Gene Ontology (GO), Kyoto Encyclopedia of Genes and Genomes (KEGG) e Biocarta.

A análise de enriquecimento em busca de processos biológicos significantes foi realizada por meio do software GSEA (Gene Set Enrichment Analysis) (SUBRAMANIAN et al., 2005) versão 2.07 do Instituto Broad do MIT. Os valores de expressão de todas as sondas foram importadas para o programa e a análise de enriquecimento foi realizada para as categorias do Gene Ontology, KEGG Pathway e Biocarta com a utilização de 1.000 permutações do tipo gene_set para cálculo do valor de $P$. $O$ restante dos parâmetros utilizados foram os padrões, exceto para "collapsing mode for probe sets $=>1$ gene" e no qual adotamos o valor representativo da mediana e "Ranking for metric classes" utilizando Diff_of_classes. Categorias com nominal (NOM) $P$ value $<0,05$ e FDR (false discovery rate) $<0,25$ foram consideradas significantes.

A identificação de vias de sinalização canônicas significantes dentro do grupo de genes diferencialmente expressos nas CTHs e CTMs de pacientes foi realizada pelo Ingenuity Pathway Analysis software (IngenuityR Systems, Redwood, CA, EUA), baseado na IPA Kwonlegde Base, considerando $P<0,05$. 
RESULTADOS 


\section{RESULTADOS}

\subsection{CÉLULAS-TRONCO HEMATOPOÉTICAS}

\subsubsection{ANÁLISE DA PUREZA DAS CÉLULAS-TRONCO HEMATOPOÉTICAS}

Das amostras de células-tronco hematopoéticas (CTHs) isoladas dos pacientes com EM no período pré-TACTH, $77,77 \%$ apresentaram pureza maior do que $90 \%$ e o número total de células $\mathrm{CD}_{3} 4^{+}$recuperadas após a passagem pela coluna no campo magnético variou de $4,0 \times 10^{5}$ a $2,0 \times 10^{6}$ células. Dentre as amostras purificadas de doadores saudáveis de medula óssea, $71,43 \%$ apresentaram pureza maior do que $90 \%$ e o número total de células $\mathrm{CD} 4^{+}$recuperadas variou de 0,75 a $3,51 \times 10^{6}$ células. No Apêndice I encontram-se dados sobre número de células e pureza das CTHs isoladas dos pacientes com EM e dos doadores saudáveis de medula óssea. A Figura 1 ilustra uma análise imunofenotípica que apresentou pureza de $97,44 \%$ de células CD34 ${ }^{+}$isoladas de um doador saudável.
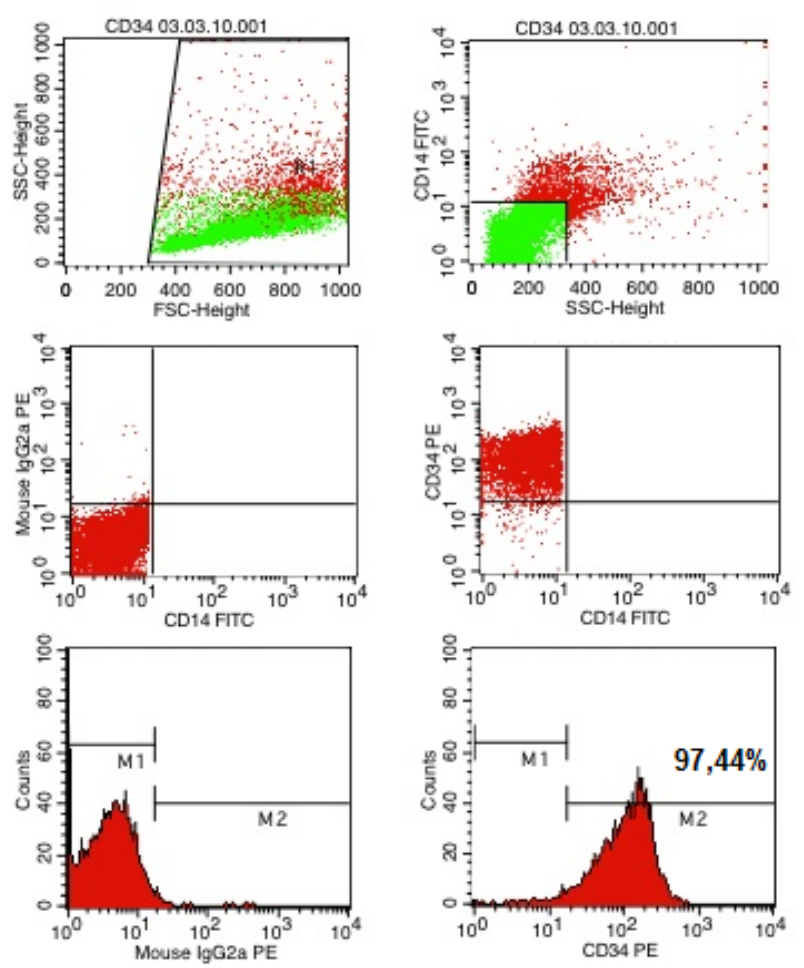

Figura 1: Análise imunofenotípica de células-tronco hematopoéticas purificadas da medula óssea de um doador saudável, mostrando $97,44 \%$ de pureza de células CD34 ${ }^{+}$. 


\subsubsection{ANÁLISE DA EXPRESSÃO GÊNICA DIFERENCIAL}

Todas as lâminas de microarrays escaneadas apresentaram: i) grid normal e cerca de 30 a 80 spots saturados (spikelns e sondas não-controle) (Apêndice II A-B); ii) as reações de hibridação, avaliadas por meio da concentração e sinal de fluorescência logarítmica dos spikes foram adequados conforme a equação da reta obtida (Apêndice II C), iii) porcentagem do coeficiente de variância menores do que 5 , valores considerados muito bons (Apêndice II D); iv) distribuição Gausseana do sinal de fluorescência dos microarrays (Apêndice II E) e v) os outliers, pontos enquadrados fora da área de análise decorrente da normalização do canal de fluorescência, apresentaram valores inferiores a 0,5\% (Apêndice II F). Em resumo, todos os parâmetros de hibridação analisados pelo software foram satisfatórios e, portanto, os dados de expressão gênica das amostras de CTHs obtidas nesse experimento foram utilizados de forma segura.

Além dos parâmetros de qualidade dos microarrays escaneados, observamos a qualidade dos dados extraídos na Figura 2, uma vez que as distribuições de massas estão concentradas no eixo zero, indicando ótima qualidade da intensidade de sinal dos microarrays hibridados. Além disso, as amostras foram submetidas à análise de componente principal (PCA - Principal Component Analysis) que gerou gráfico com a dispersão espontânea das amostras utilizadas nas hibridações. Como observamos na Figura 3, as amostras de CTHs isoladas de pacientes com EM agruparam de forma consistente, com maior proximidade entre as amostras (em azul). Em contrapartida, as amostras de CTHs isoladas de doadores saudáveis de medula óssea apresentaram maior dispersão (em vermelho). 


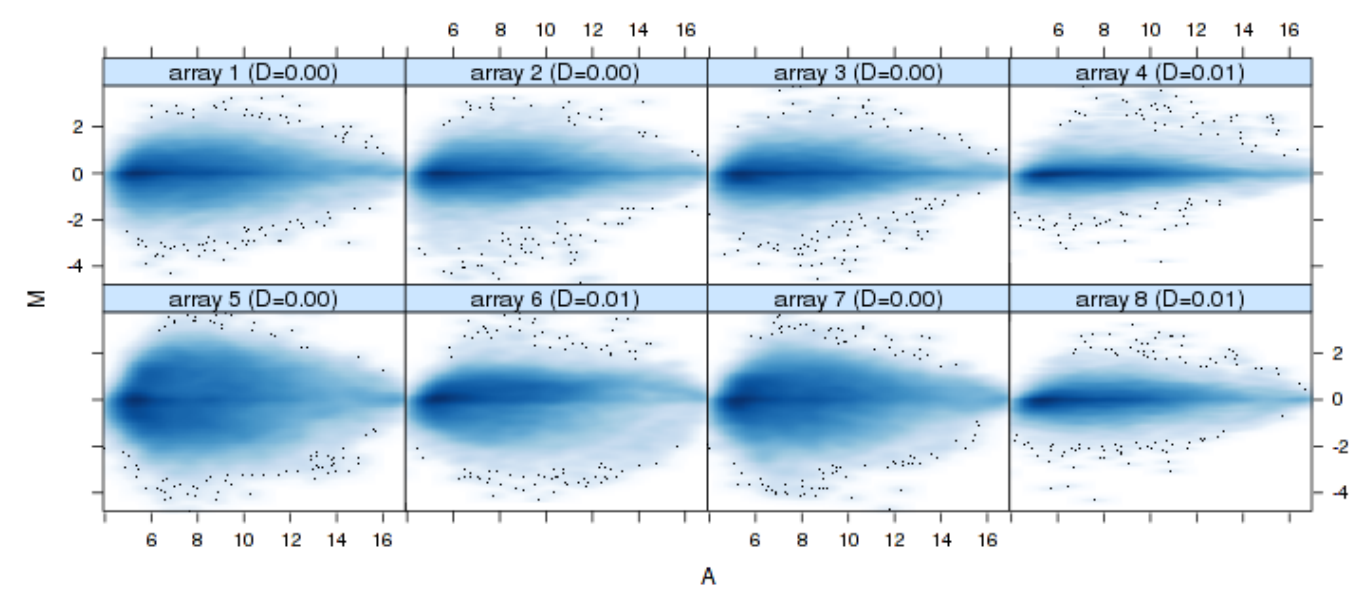

Figura 2: MA plots representando os dados de intensidade de fluorescência dos microarrays. O MA plot calcula a razão entre a intensidade de sinal de cada microarray (representado no eixo x) e a intensidade de sinal gerada pela mediana dos sinais de todos os microarrays (representada no eixo y).

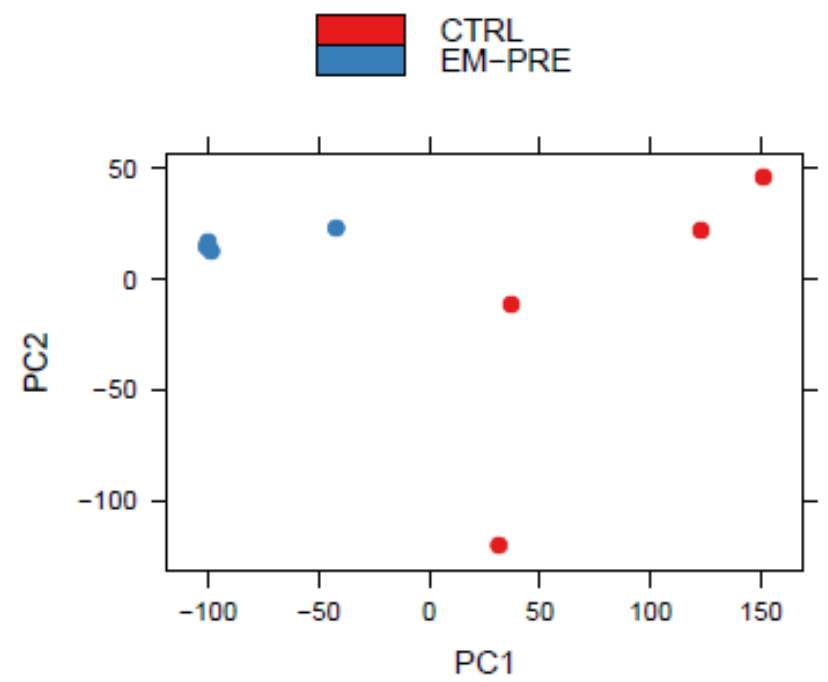

Figura 3: Dispersão espontânea das amostras de células-tronco hematopoéticas hibridadas nos microarrays por meio da análise de componente principal. As amostras de células-tronco hematopoéticas isoladas de doadores saudáveis estão representadas em vermelho e de pacientes com esclerose múltipla, em azul.

Os dados de expressão gênica foram filtrados e normalizados, permitindo a comparação e correlação da expressão gênica entre os grupos de CTHs isoladas de doadores saudáveis de medula óssea e pacientes com EM. Observamos que os microarrays de cada grupo apresentaram normalização adequada, conforme verificado pelas posições e larguras similares das caixas de normalização, como mostra a Figura 4. 


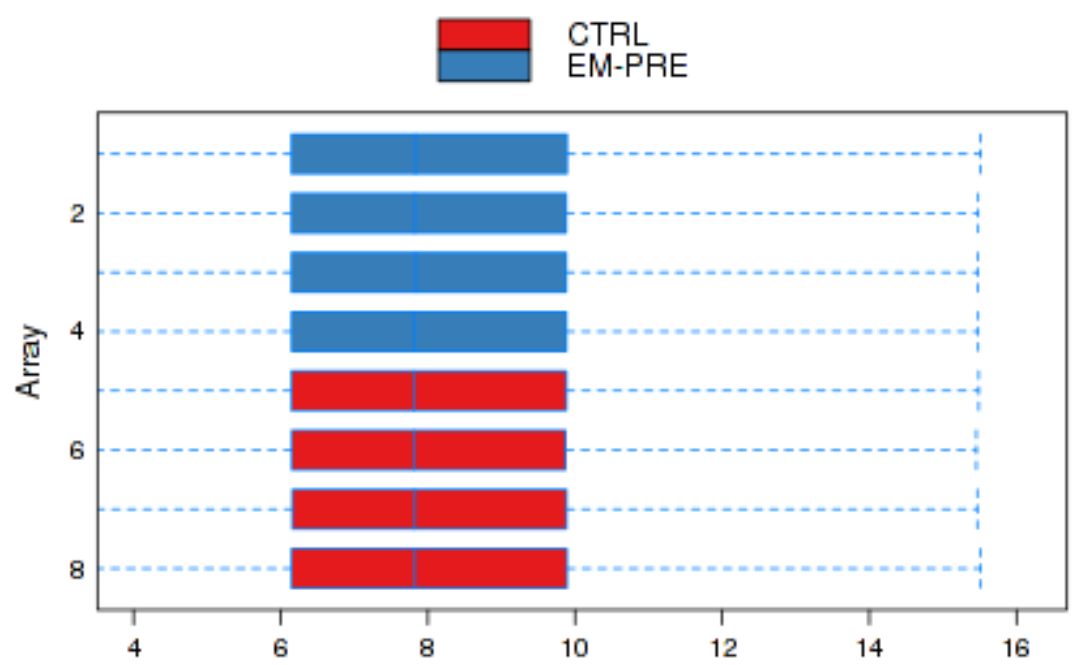

Figura 4: Normalização dos dados de expressão gênica das células-tronco hematopoéticas isoladas de doadores saudáveis de medula óssea e de pacientes com esclerose múltipla. $O$ box plot mostrado representa o sumário de distribuição dos valores de intensidade de fluorescência normalizados para cada grupo de microarrays, sendo que cada box corresponde a um microarray.

Após as etapas de pré-processamento e normalização, os dados foram submetidos ao agrupamento hierárquico simples, com o objetivo de analisá-los de acordo com o perfil de similaridade gênica. A Figura 5 mostra a clusterização hierárquica euclideana simples dos dados de expressão gênica das CTHs isoladas de doadores saudáveis de medula óssea e de pacientes com EM. Neste agrupamento hierárquico, podemos observar que existem diferenças no perfil de expressão gênica entre as CTHs isoladas de pacientes e controles, havendo formação de dois agrupamentos diferentes. O primeiro grupo é formado pelas quatro amostras provenientes dos pacientes com EM (EM05-PRE.453.1.1; EM09PRE.453.1.4; EM07-PRE.453.1.2; EM08-PRE.453.1.3) e, o segundo, formado pelas quatro amostras isoladas de doadores saudáveis (CTRL.NM40.841.1.1; CTRL.NM43.841.1.3; CTRL.NM42.841.1.2; CTRL.NM44.841.1.4). Considerando que ambos os grupos celulares foram derivadas de condições semelhantes de isolamento, esses resultados mostram que estas células apresentam perfis de expressão gênica diferentes (Figura 5). 


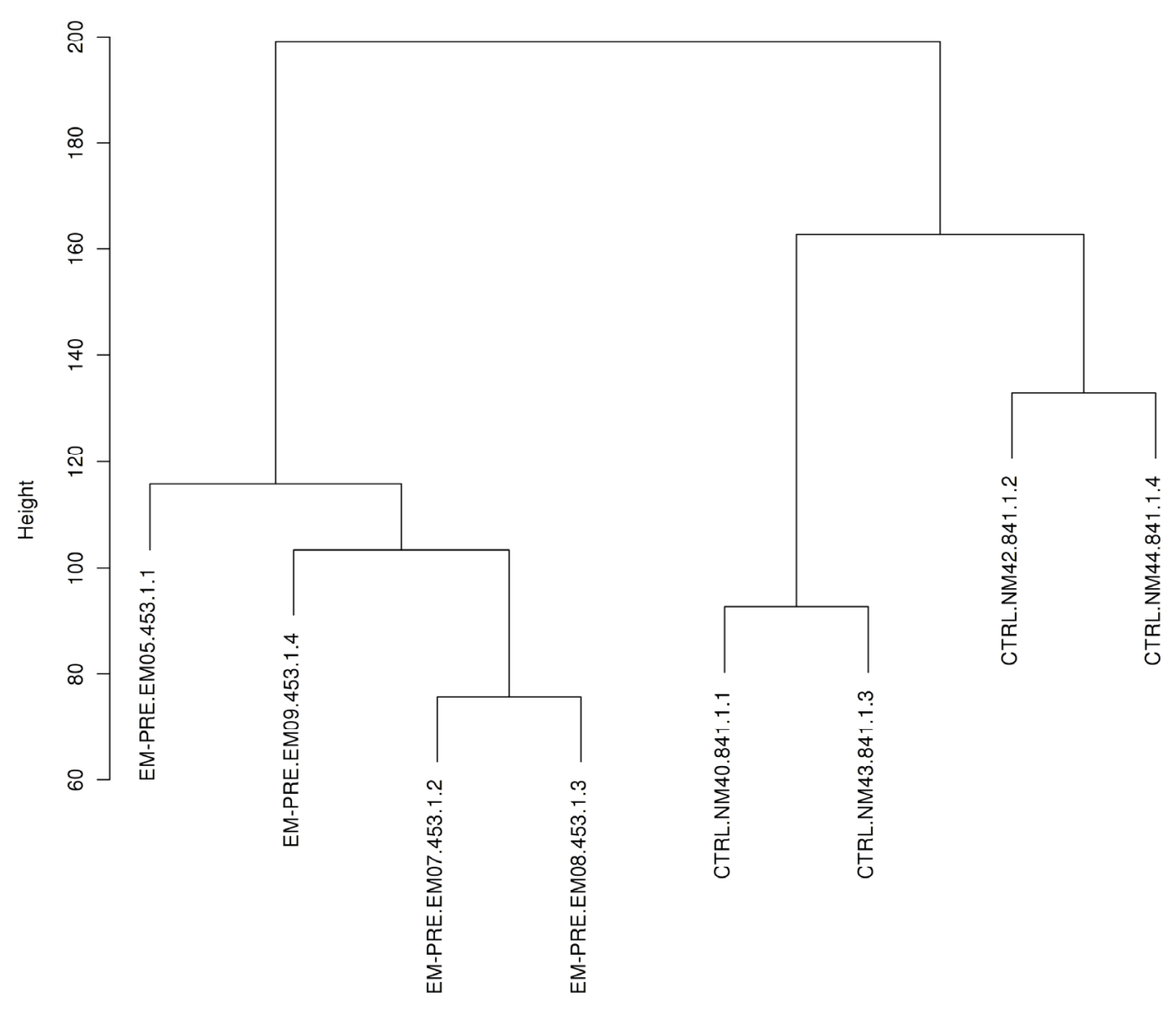

d

hclust (", "average")

Figura 5: Clusterização hierárquica euclideana simples dos dados de expressão gênica das células-tronco hematopoéticas isoladas de doadores saudáveis de medula óssea e de pacientes com esclerose múltipla. Os dendogramas foram gerados através da plataforma $R$ pela análise da expressão de todas as sondas.

Uma vez que foram observadas diferenças nos perfis de expressão gênica entre as CTHs isoladas de doadores saudáveis e pacientes com EM, através das análises de agrupamento hierárquico, partimos para a fase de identificação dos genes diferencialmente expressos. Dessa forma, considerando o fold change $\geq 2,0$ e valor de $P<0,01$, foi possível identificar um total de 2.722 genes diferencialmente expressos nas CTHs dos pacientes em relação à expressão nas células dos doadores saudáveis. Desse total, foram encontrados 1.769 genes reprimidos e 953 genes induzidos nas células dos pacientes em relação aos controles, como mostrado no Volcano plot (Figura 6). Podemos observar essas diferenças de genes reprimidos e induzidos nas células dos pacientes em relação as células controle no heatmap gerado pela clusterização supervisionada após análise estatística (Figura 7). 


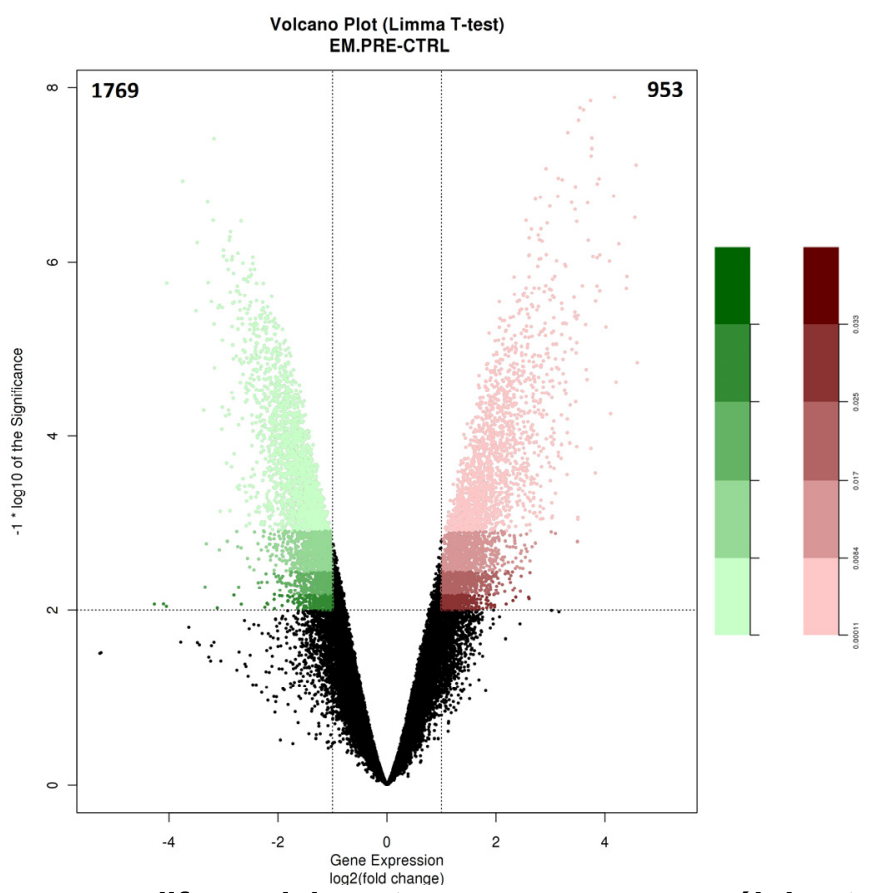

Figura 6: Grupo de genes diferencialmente expressos nas células-tronco hematopoéticas isoladas de pacientes com esclerose múltipla em comparação às células controle. $O$ Volcano plot mostra o fold change $\geq 2$ versus a significância estatística $(P<0,01)$ dos dados de expressão gênica, indicando em verde os genes reprimidos nas células dos pacientes, e, em vermelho, os genes induzidos. Em preto, estão representados genes sem alterações na expressão entre os grupos.

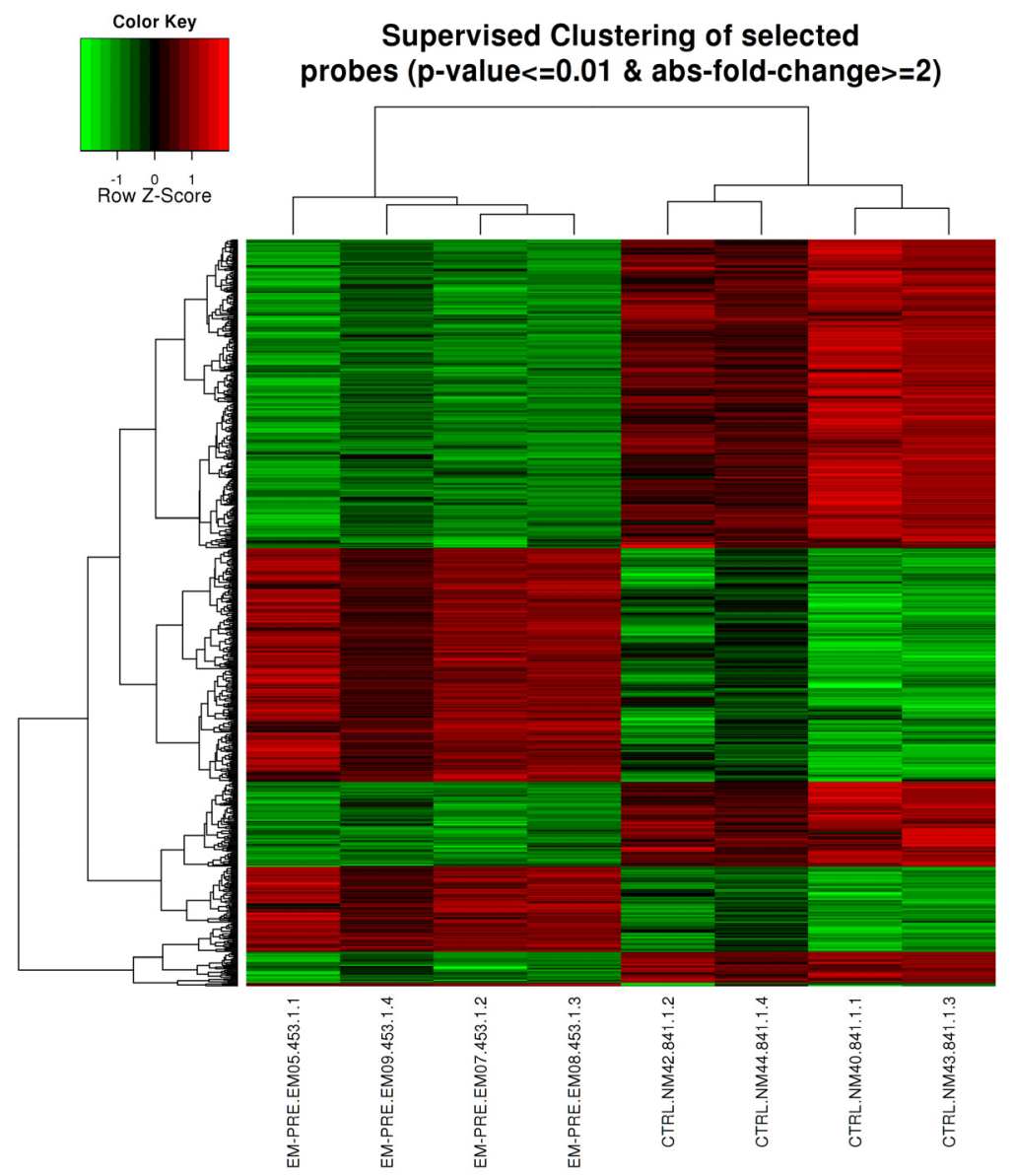

Figura 7: Clusterização supervisionada de sondas com maior variância de expressão entre as células-tronco hematopoéticas isoladas de indivíduos saudáveis e de pacientes com esclerose múltipla. 
Além disso, escolhemos algumas categorias, tais como, citocinas/receptores de citocinas, quimiocinas/receptores de quimiocinas, moléculas de adesão e fatores de transcrição para descrever alguns genes diferencialmente expressos nas CTHs dos pacientes em relação às células controle.

Dentro da categoria citocinas/receptores de citocinas, observmos que os genes ANGPT1, TGFBR1 e IL1RAP estão induzidos nas CTHs dos pacientes, e os genes CSF1, TNFRSF1A, VEGFB, IL12RB1, GDF11, SIGIRR, VEGFA, IL3RA, MST1R, TIE1, TNFRSF4, EPHB4, BMP1, TYRO3, AMHR2, IL15RA, CCR5, EPHA1, TNFRSF1B, IL10RA, CCRL2, NTRK1, IL4, CCR7, CSF2RA, TNFSF13, CX3CR1 e GAS6 estão reprimidos nas células dos pacientes em relação às $C T H$ s controle.

Com relação às quimiocinas/receptores de quimiocinas, observamos indução do gene C5 e repressão da expressão dos genes CXCR2, CCL5, CX3CR1 e CXCR3 nas CTHs dos pacientes com EM em relação às células controle.

Dentre as moléculas de adesão, encontramos indução dos genes ITGA6, ADAMTSL4, CXADR, ADAM28 e ADAM10 e repressão dos genes CD59, CDH23, COL18A1, ITGA2B, VEGFB, PVRL2, VEGFA, ITGAL, PVRL1, AGRN, NTN3, SELPLG, SIGLEC5, ITGAX, ITGB7, PVR, LGALS1, SIGLEC9, ITGB3, PODXL2, BTLA, TGM2 e $A D A M 15$ nas células dos pacientes em relação CTHs controle.

Finalmente, dentre os fatores de transcrição, observamos indução de ZNF85, NFAT5, TCF4, JUN, POU2F1, MORF4, HIF1A, NR3C1, ZNF256, FUBP1, PHTF1, SOX4, ZEB1, NFE2L2, NFATC2, HSF2, MYEF2, ELF1, ZBTB38, ZRANB2, SP140, RBP5, TFAM e NFYB e repressão dos fatores ZBTB48, TCF25, SREBF1, TCF19, STAT5A, E2F4, RELA, THRA, TGIF1, FOXO4, ZNF174, GATA1, MBD1, IRF9, MYBL2, ELK1, NPAS1, FOSL1, TRIM28, SCAND1, SNAPC2, SLC2A4RG, TP53 USF2, HES6, KLF1 e GTF2H4 nas células dos pacientes em relação às CTHs controle.

\subsubsection{ENRIQUECIMENTO FUNCIONAL DOS GENES DIFERENCIALMENTE EXPRESSOS}

Após identificação de genes diferencialmente expressos nas CTHs dos pacientes, o enriquecimento funcional desses genes foi realizado pelo software David Functional Annotation Bioinformatic Microarray, como descrito em Materiais e Métodos.

Dentre os 1.769 genes reprimidos na relação dos diferencialmente expressos nas CTHs de pacientes, encontramos alterações significantes na expressão de genes relacionados com processos biológicos, componentes celulares e funções moleculares (categorias do Gene Ontology), como mostra a Figura 8. 
A)

Processos biológicos

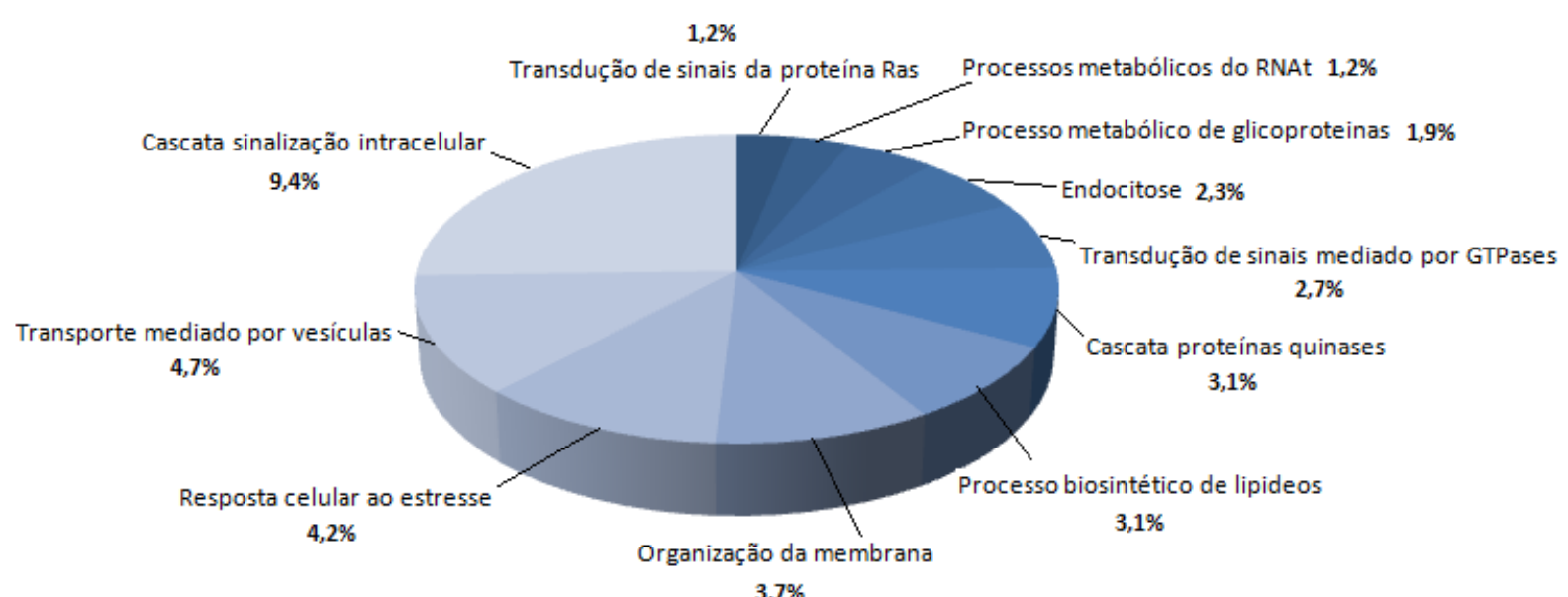

B)

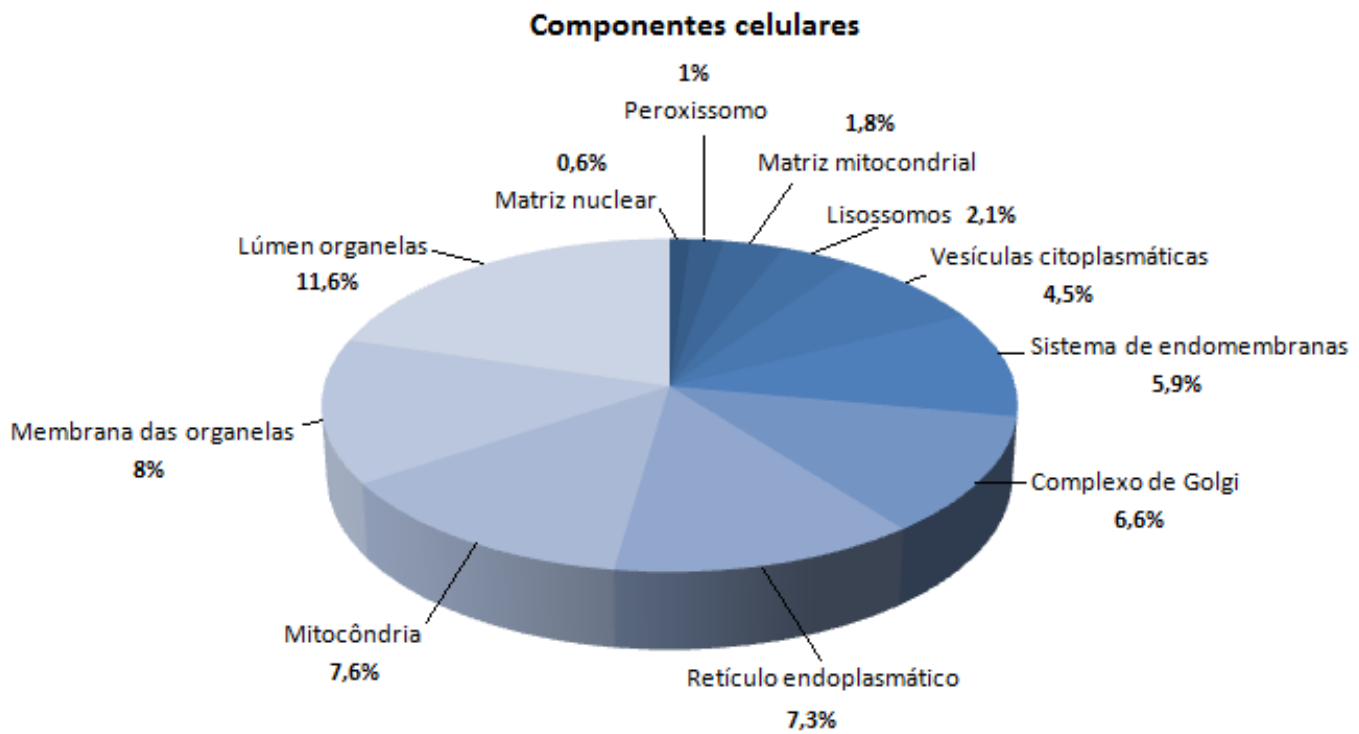

C)

Funções moleculares

$1,1 \%$

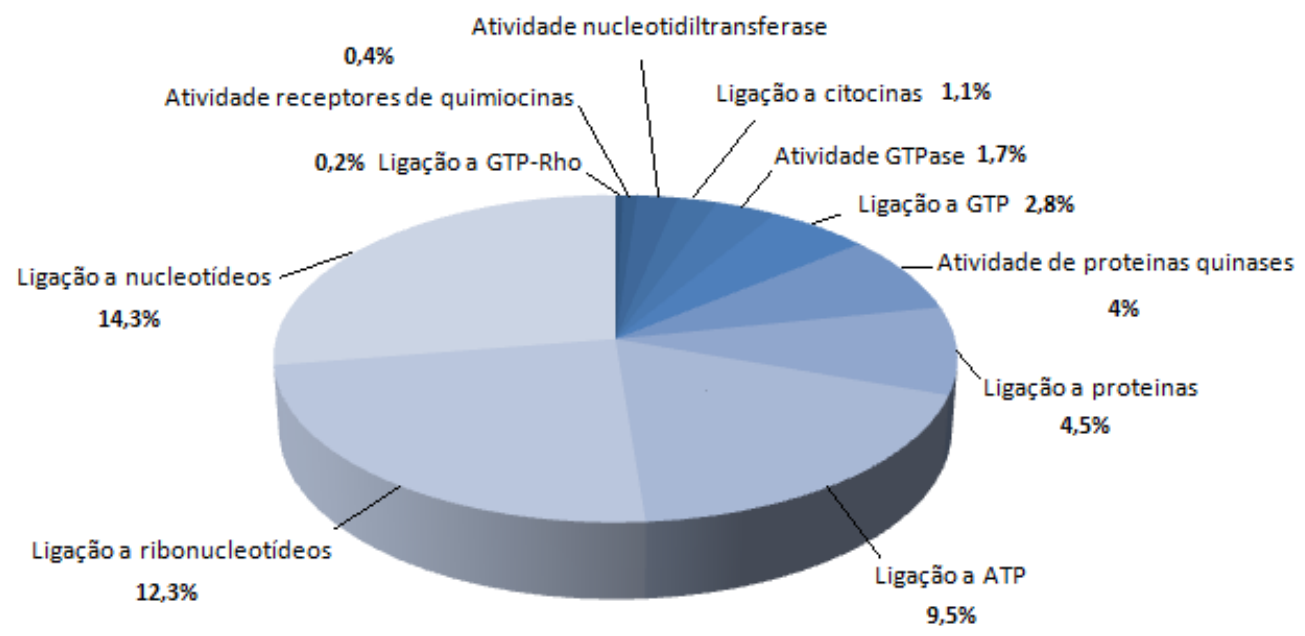

Figura 8: Classificação dos genes reprimidos nas células-tronco hematopoéticas de pacientes com esclerose múltipla em funções biológicas. 
Além das alterações em genes pertencentes as classificações do Gene Ontology, foram encontrados genes reprimidos em vias de sinalização importantes (KEGG Pathways), como mostra a Figura 9.

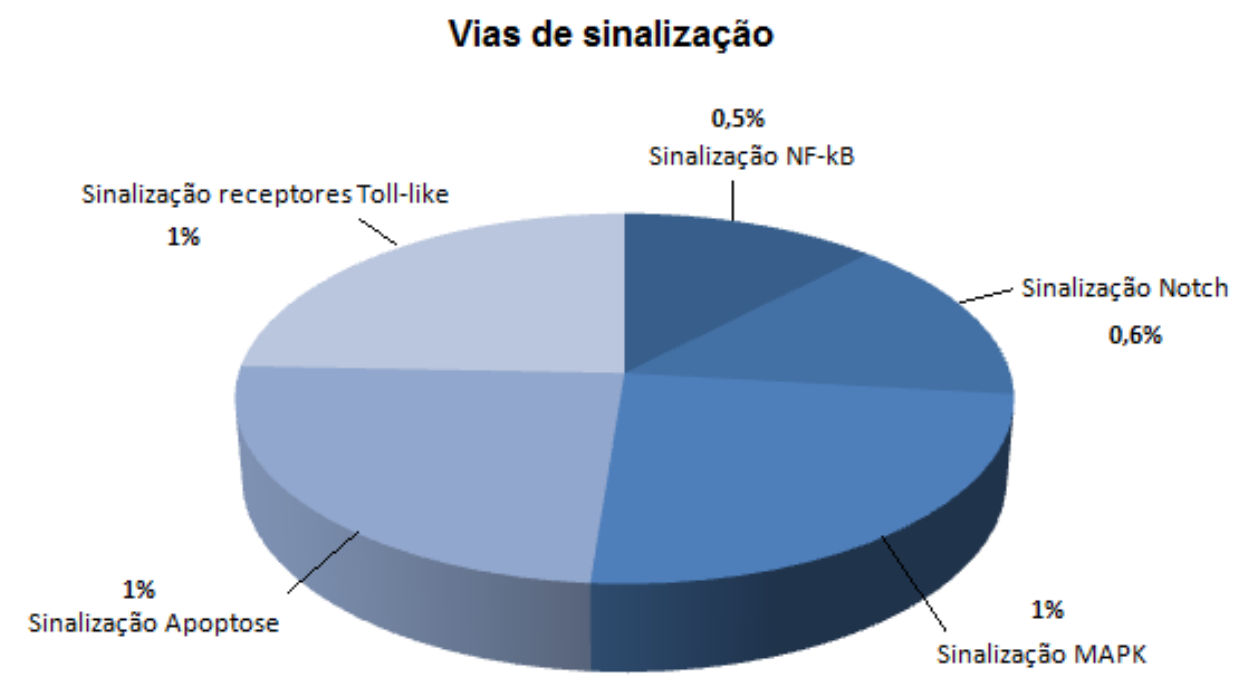

Figura 9: Classificação dos genes reprimidos nas células-tronco hematopoéticas de pacientes com esclerose múltipla em vias de sinalização.

De maneira similar, dentre os 953 genes induzidos nas CTHs de pacientes com EM, encontramos alterações significantes na expressão de genes relacionados com processos biológicos, componentes celulares e funções moleculares (Figura 10), e ainda, em vias de sinalização importantes (Figura 11). 
A)

Processos biológicos

$2,1 \%$

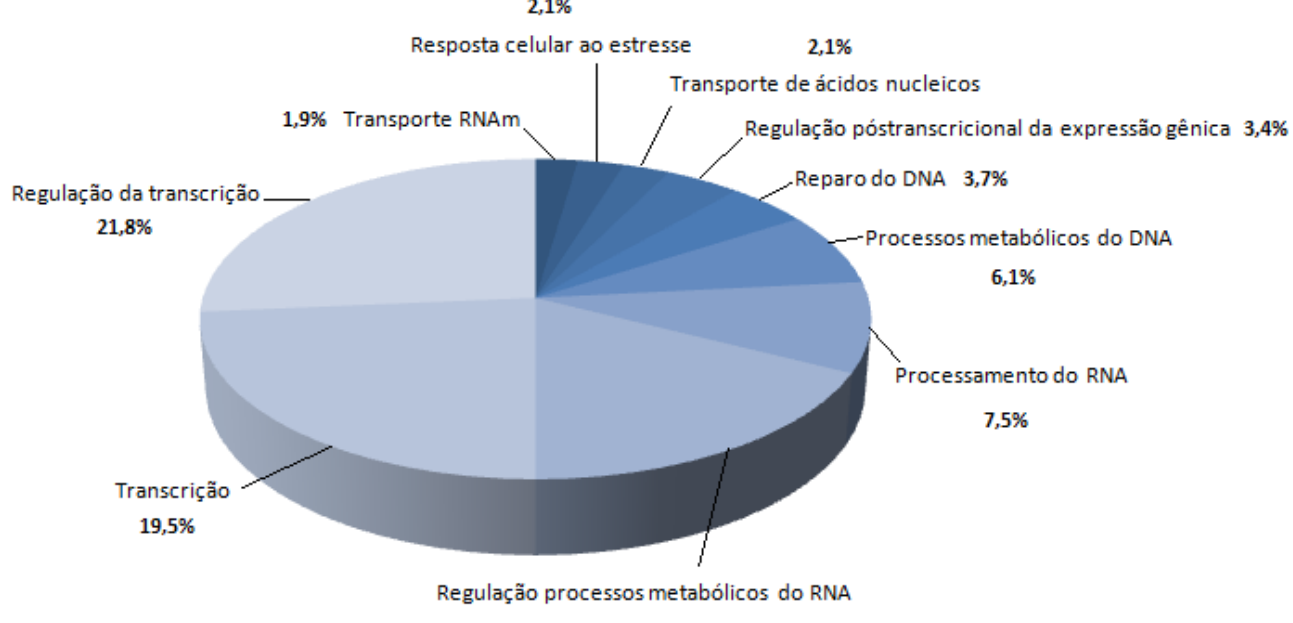

$14,5 \%$

B)

Componentes celulares

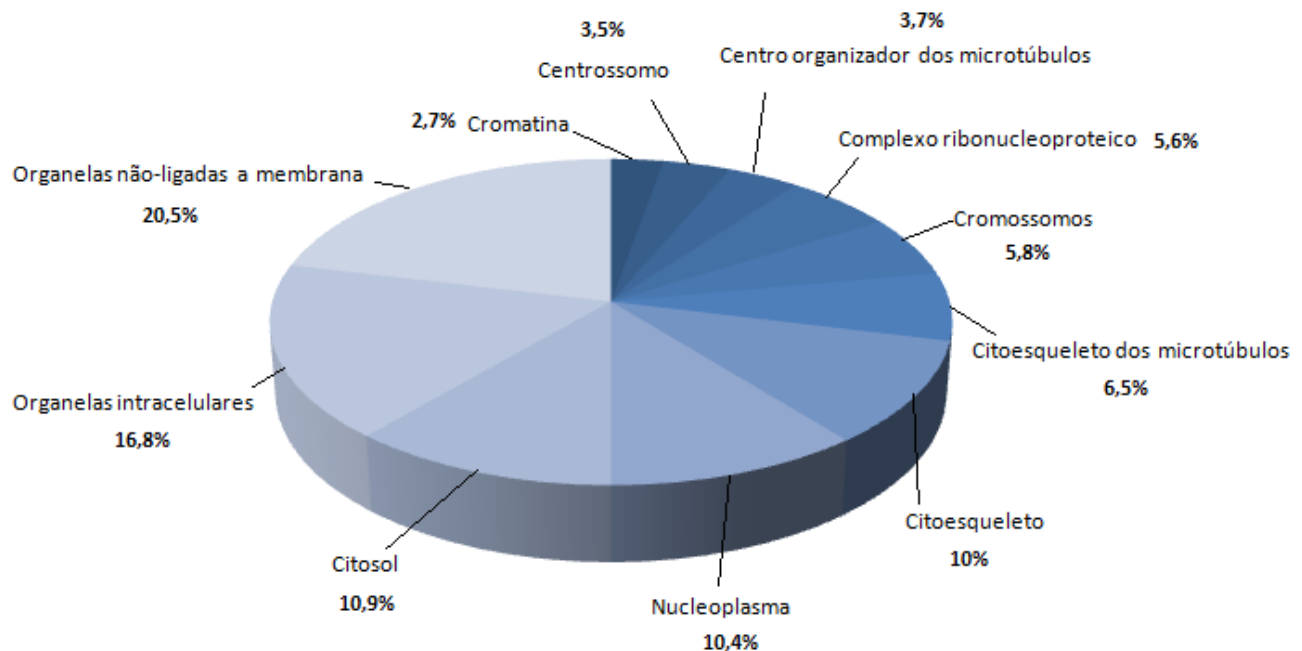

C)

Funções moleculares

$2,5 \%$

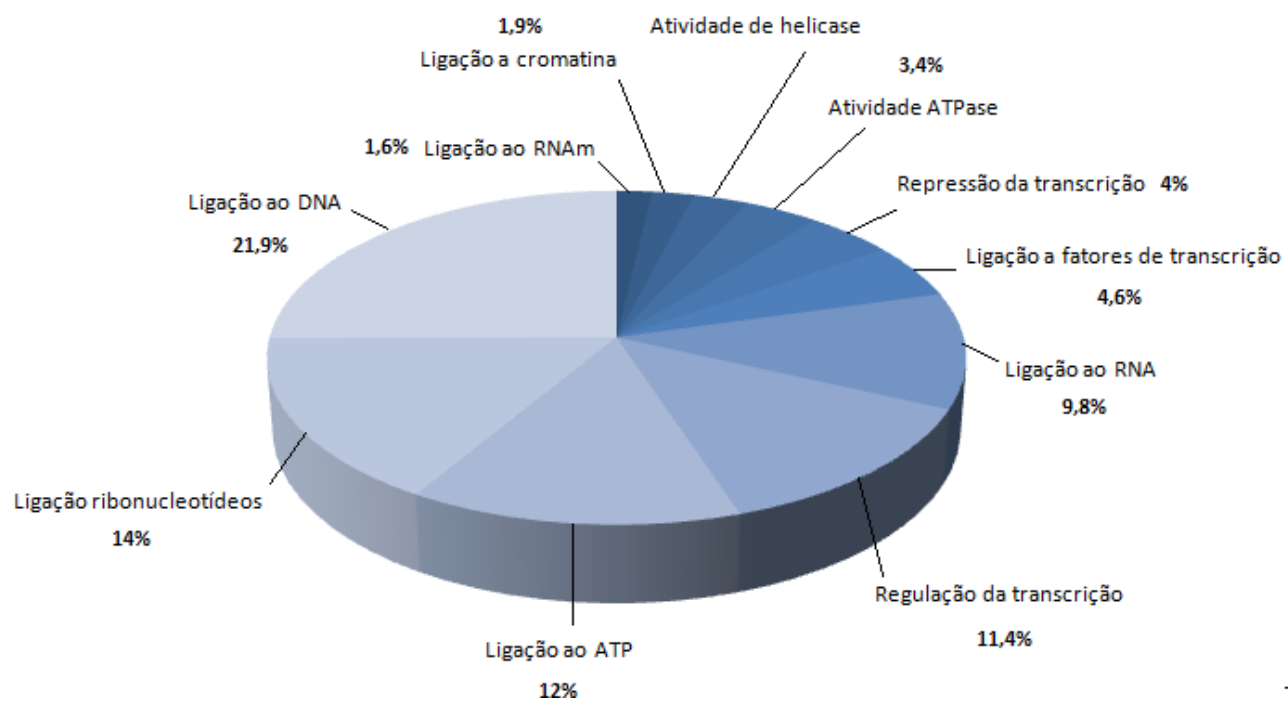

Figura 10: Classificação dos genes induzidos nas células-tronco hematopoéticas de pacientes com esclerose múltipla em funções biológicas. 


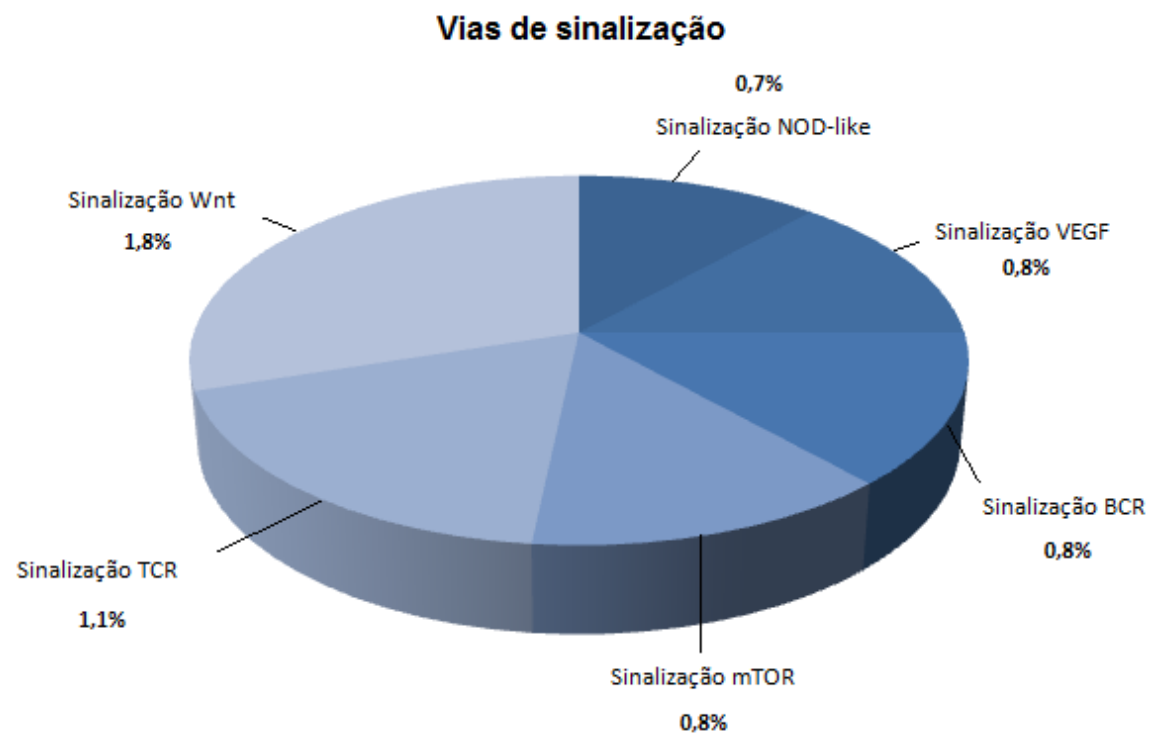

Figura 11: Classificação dos genes induzidos nas células-tronco hematopoéticas de pacientes com esclerose múltipla em vias de sinalização.

Uma vez que foram encontradas alterações significantes em vias de sinalização importantes para manutenção, proliferação e diferenciação das CTHs, escolhemos quatro vias importantes e observamos os genes reprimidos e induzidos dentro dessas vias.

Dentro da via de sinalização da apoptose observamos expressão induzida dos genes CAPN1, PRKACB, PIK3R1, PIK3CA, IRAK3, CASP8, CASP7, IL1RAP, PRKX, CASP3, PPP3R1, PPP3CC, PRKAR2B, BIRC2, XIAP e IRAK4 e repressão dos genes DFFA, BID, CHP, PRKACA, BAD, RELA, PIK3R2, BAX, PIK3R5, TNFRSF10C, IKBKG, TRAF2, TRADD, AKT1, AKT2, BCL2L1, IL3RA, MYD88, TNFRSF1A, IRAK1, PRKAR1B, TP53, NTRK1, ENDOG, PIK3CD e FADD, conforme heatmap (Figura 12A).

$\mathrm{Na}$ sinalização Notch observamos repressão dos genes HES5, APH1A, PTCRA, PSEN2, DTX2, RFNG, NOCTH4, PSENEN, CTBP1, MFNG e DVL3 e indução dos genes RBPJ, SNW1, CIR1, ADAM17, CTBP2, CREBBP e EP300 (Figura 12B).

$\mathrm{Na}$ via Wnt encontramos indução dos genes PPP2R5C, NFAT5, CSNK1A1, JUN, CSNK1A1L, PRKACB, ROCK1, ROCK2, PLCB4, CSNK2A2, NFATC2, CCND2, SMAD2, MAP3K7, PPP2CA, SENP2, DAAM1, SIAH1, PPP3R1, EP300, PPP3CC, CTBP2, CREBBP, FBXW11, CSNK2A1, SKP1, CDH8, SMAD4 e CSNK2B e repressão de CHP, CSNK1E, PRKACA, RUVBL1, APC2, DVL3, PPP2R5B, FRAT2, VANGL1, FZD9, CTBP1, CCND1, FOSL1, RAC3, WNT5B, PLCB3, FRAT1, TP53, FZD5, CCND3 e FZD2 (Figura 13A).

$\mathrm{Na}$ via mTOR encontramos indução dos genes RICTOR, RPS6KB1, TSC1, HIF1A, PIK3R1, PIK3CA, PRKAA1, EIF4B, CAB39, RPS6KA3 e EIF4E e, repressão dos genes TSC2, PIK3R2,PIK3R5, RPS6KA1, MAPK3, AKT1, AKT2, DDIT4, VEGFA, PGF, MLST8, VEGFB, IGF1, STK11 e PIK3CD (Figura 13B). 
A)
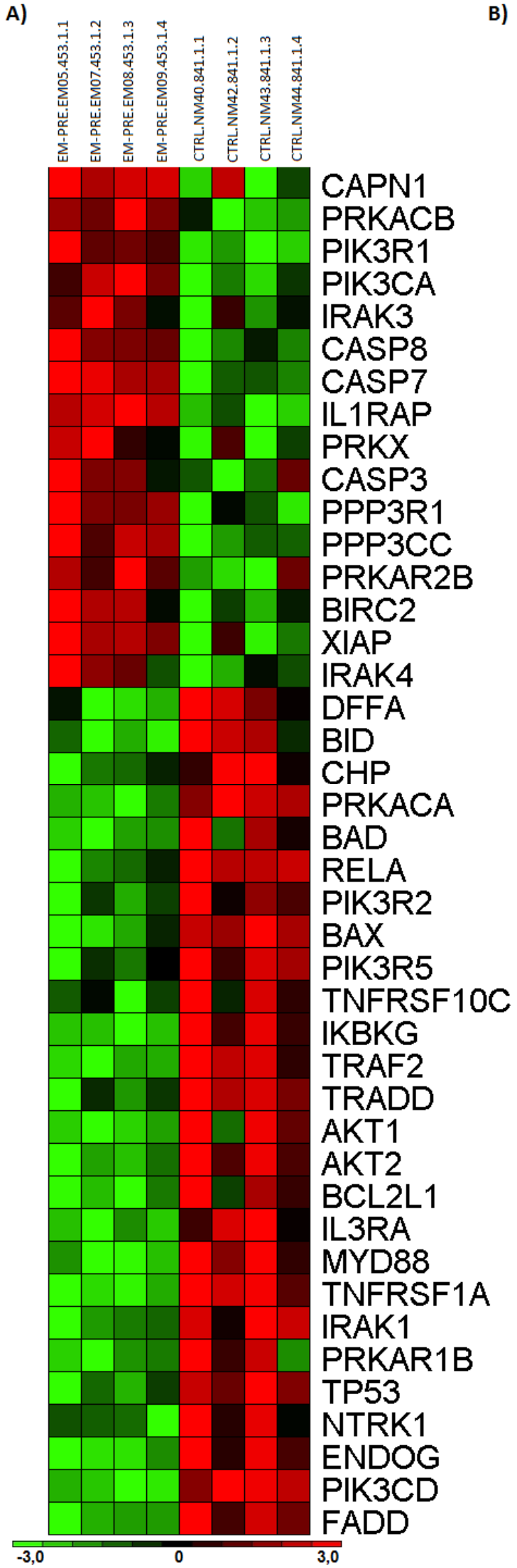

B)

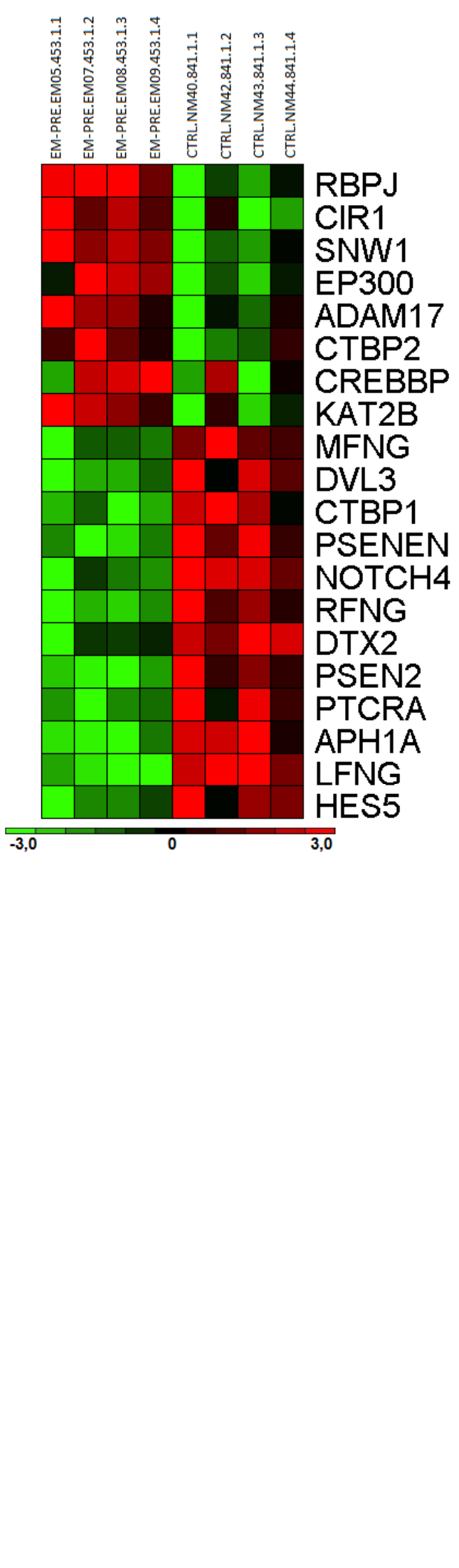

Figura 12: Heatmap contendo genes induzidos e reprimidos, pertencentes às vias de sinalização (A) da apoptose e (B) Notch, nas células-tronco hematopoéticas de pacientes com esclerose múltipla. O heatmap foi gerado pelo GenePattern, utilizando-se os valores de expressão (log2) após análise estatística. 
A)
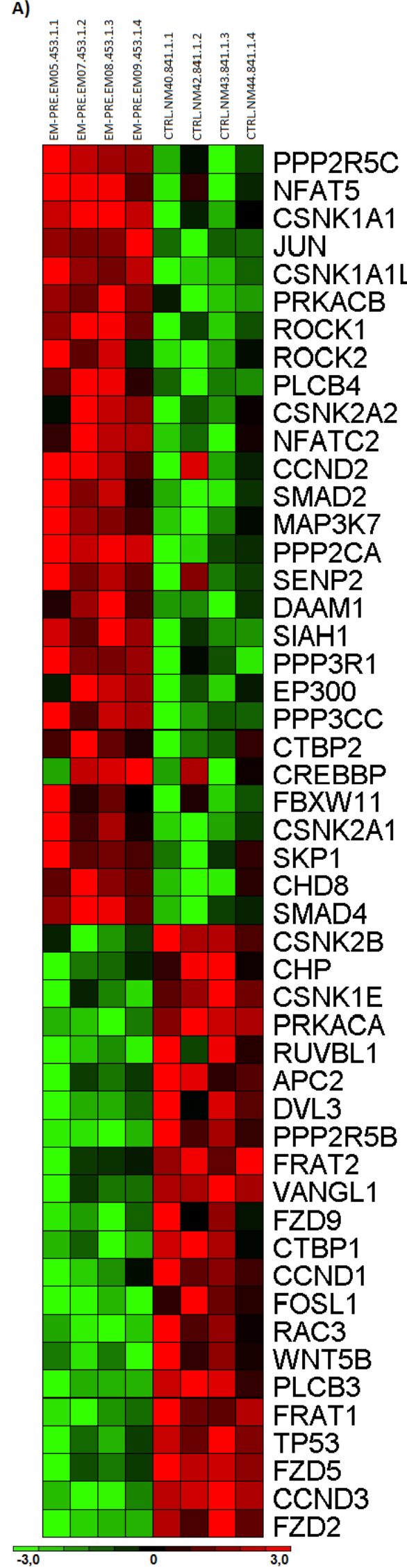

B)

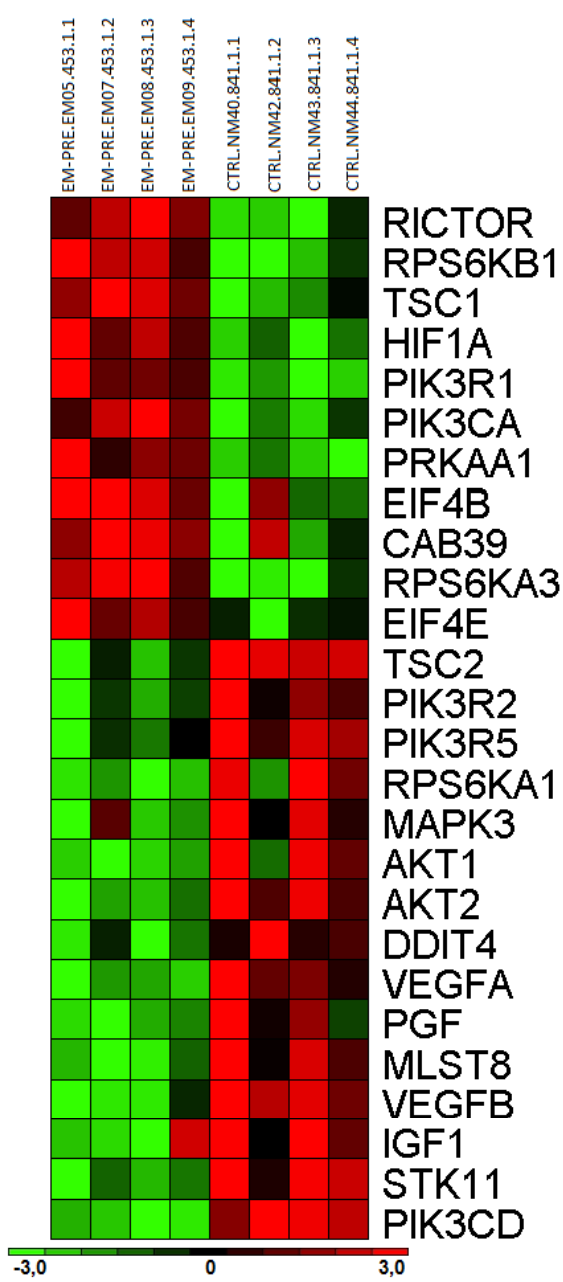

Figura 13: Heatmap contendo genes induzidos e reprimidos, pertencentes às vias de sinalização (A) Wnt e (B) mTOR, nas células-tronco hematopoéticas de pacientes com esclerose múltipla. O heatmap foi gerado pelo GenePattern, utilizando-se os valores de expressão (log2) após análise estatística. 


\subsubsection{ANÁLISE DE PROCESSOS BIOLÓGICOS SIGNIFICANTES}

Quando realizamos análises por enriquecimento pelo software Gene Set Enrichment Analysis em busca de alterações em processos biológicos, encontramos alguns processos significantes de relevância para nosso estudo. Dentre esses resultados, os dois processos biológicos de maior significância estatística foram: a via de sinalização EIF4 e mTOR. Destacamos também as vias do Fas, da apoptose celular e a da calcineurina, relacionada com ativação celular. A Tabela 3 mostra esses processos biológicos significantes, com os escores de enriquecimento, valores de $P$ e taxa de falsa descoberta. A Figura 14 mostra os heatmaps gerados pelo GSEA dentro de alguns processos biológicos escolhidos, indicando genes induzidos e reprimidos nas CTHs dos pacientes em relação às células controle. Os asteriscos na frente dos genes indicam que estes estão incluídos na lista dos genes diferencialmente expressos (FC $\geq 2 ; P<0,01)$.

Tabela 3: Conjunto de processos biológicos significantes gerados pelo Gene Set Enrichment Analysis quando comparamos as células-tronco hematopoéticas de pacientes com esclerose múltipla às células controle.

\begin{tabular}{lccc}
\hline \multicolumn{1}{c}{ Processos biológicos } & NES & NORM p-val & FDR q-val \\
\hline \hline 1. BIOCARTA EIF4 pathway & 2,10 & 0,000 & 0,016 \\
2. BIOCARTA MTOR pathway & 2,07 & 0,000 & 0,011 \\
3. BIOCARTA EIF pathway & 1,89 & 0,012 & 0,053 \\
4. BIOCARTA TPO pathway & 1,76 & 0,003 & 0,108 \\
5. BIOCARTA PPARA pathway & 1,69 & 0,008 & 0,144 \\
6. BIOCARTA CTCF pathway & 1,65 & 0,015 & 0,167 \\
7. BIOCARTA GPCR pathway & 1,58 & 0,017 & 0,214 \\
8. BIOCARTA VEGF pathway & 1,58 & 0,029 & 0,194 \\
9. BIOCARTA FAS pathway & 1,57 & 0,031 & 0,184 \\
10. BIOCARTA MEF2D pathway & 1,55 & 0,042 & 0,180 \\
11. BIOCARTA CALCINEURIN pathway & 1,51 & 0,047 & 0,217 \\
\hline \hline
\end{tabular}

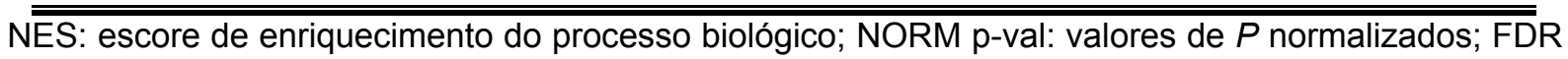
q-val: taxa de falsa descoberta. *genes incluídos na lista dos genes diferencialmente expressos $(\mathrm{FC} \geq 2 ; P<0,01)$. 
A) mTOR pathway

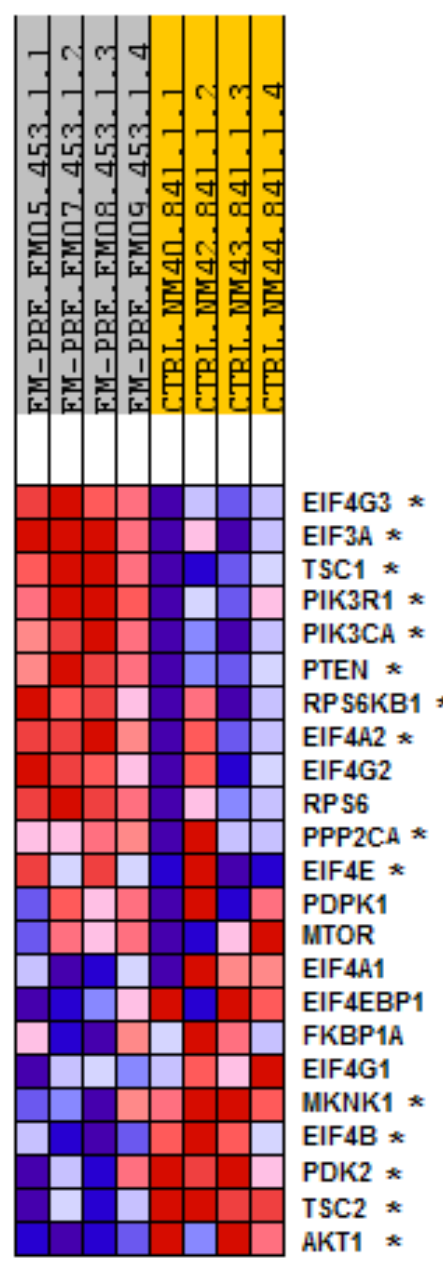

B) Fas pathway

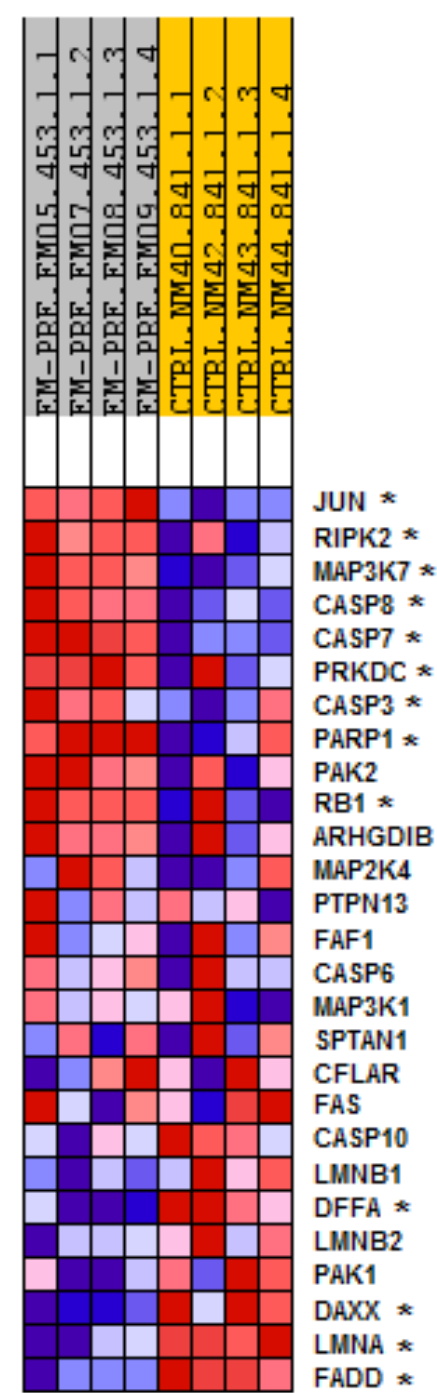

C) Calcineurin pathway

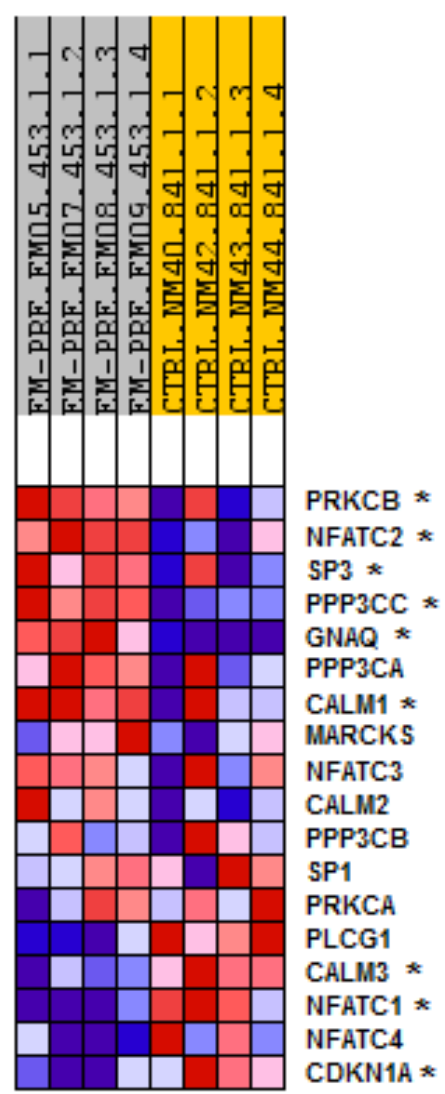

Figura 14: Heatmaps gerados pelo Gene Set Enrichment Analysis contendo genes enriquecidos dentro dos processos biológicos significantes quando comparamos as célulastronco hematopoéticas de pacientes com esclerose múltipla às células controle. A) Sinalização mTOR; B) Sinalização Fas; C) Sinalização da Calcineurina. *genes incluídos na lista dos genes diferencialmente expressos $(\mathrm{FC} \geq 2 ; P<0,01)$.

\subsubsection{ANÁLISE DE VIAS DE SINALIZAÇÃO CANÔNICAS SIGNIFICANTES}

A comparação entre o perfil de expressão gênica das CTHs isoladas de pacientes com EM e de doadores saudáveis de medula óssea revelou alterações significantes em genes pertencentes a vias de sinalização canônicas importantes, como a PI3K/AKT $(P=3,03 e-05)$, sinalização mTOR $(P=1,28 \mathrm{e}-04)$ e apoptose $(P=4,57 \mathrm{e}-03)$ (Figuras 15,16 e 17). 


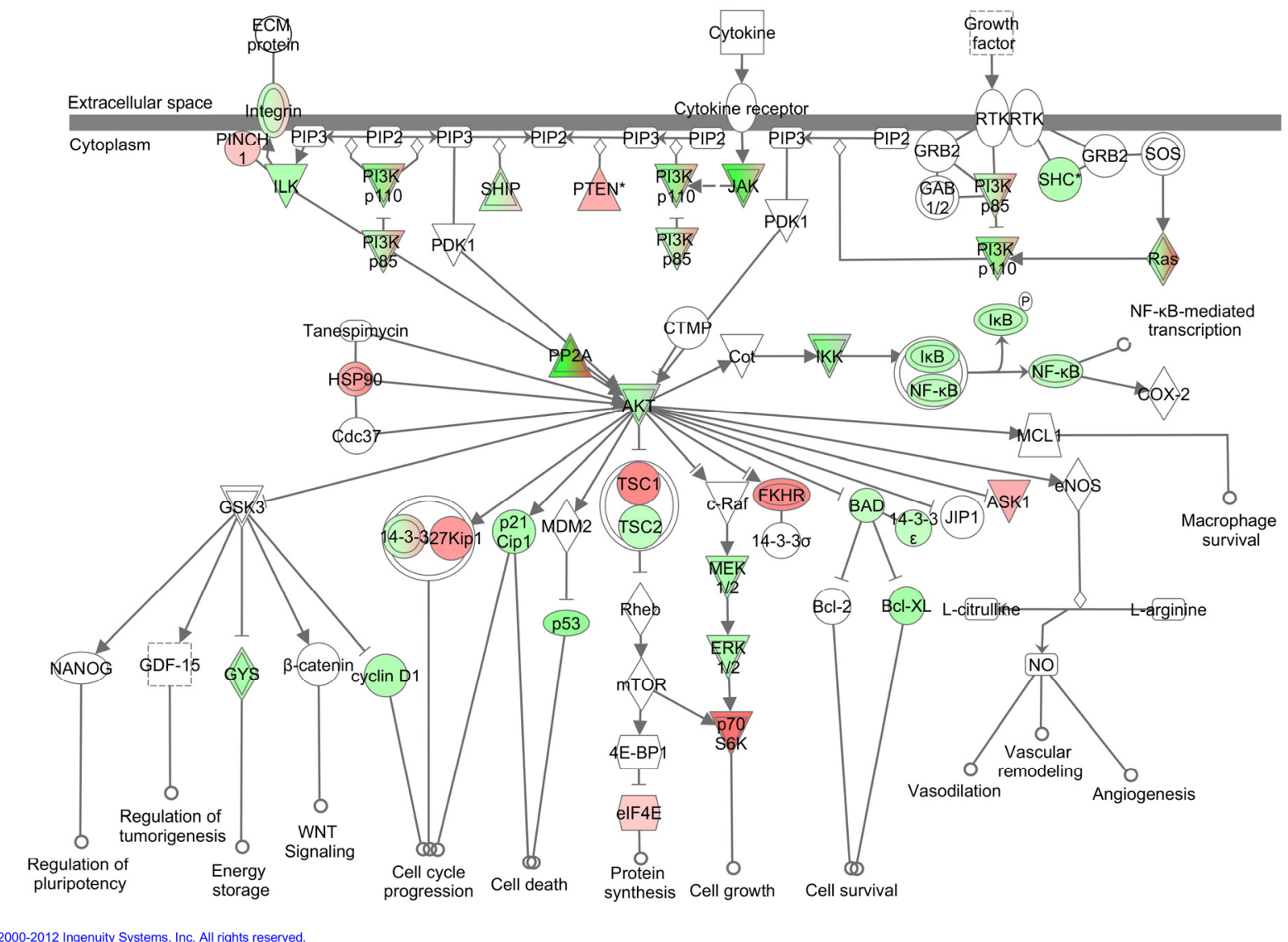

Figura 15: Via de sinalização PI3K/AKT gerada pelo software Ingenuity Pathway Analysis quando comparamos as células-tronco hematopoéticas de pacientes com esclerose múltipla às células controle. As cores verde e vermelha representam, respectivamente, repressão ou indução da expressão gênica nas células-tronco hematopoéticas dos pacientes, em comparação às células controle. A intensidade das cores é proporcional à razão de expressão (fold change) entre os sinais obtidos nos microarrays. 


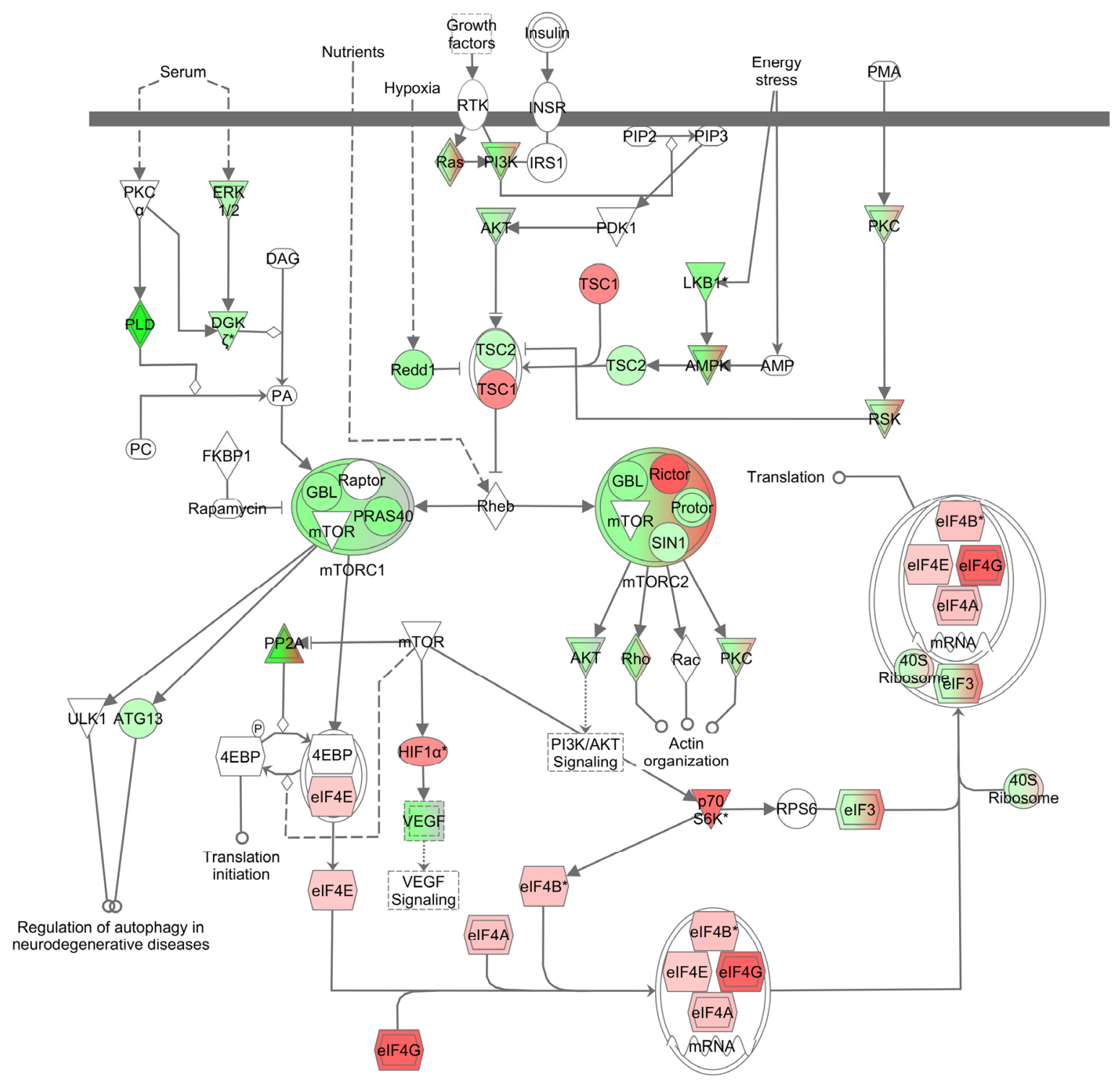

(9) 2000-2012 Ingenuity Systems, Inc. All rights reserved.

Figura 16: Via de sinalização mTOR gerada pelo software Ingenuity Pathway Analysis quando comparamos as células-tronco hematopoéticas de pacientes com esclerose múltipla às células controle. As cores verde e vermelha representam, respectivamente, repressão ou indução da expressão gênica nas células-tronco hematopoéticas dos pacientes, em comparação às células controle. A intensidade das cores é proporcional à razão de expressão (fold change) entre os sinais obtidos nos microarrays. 


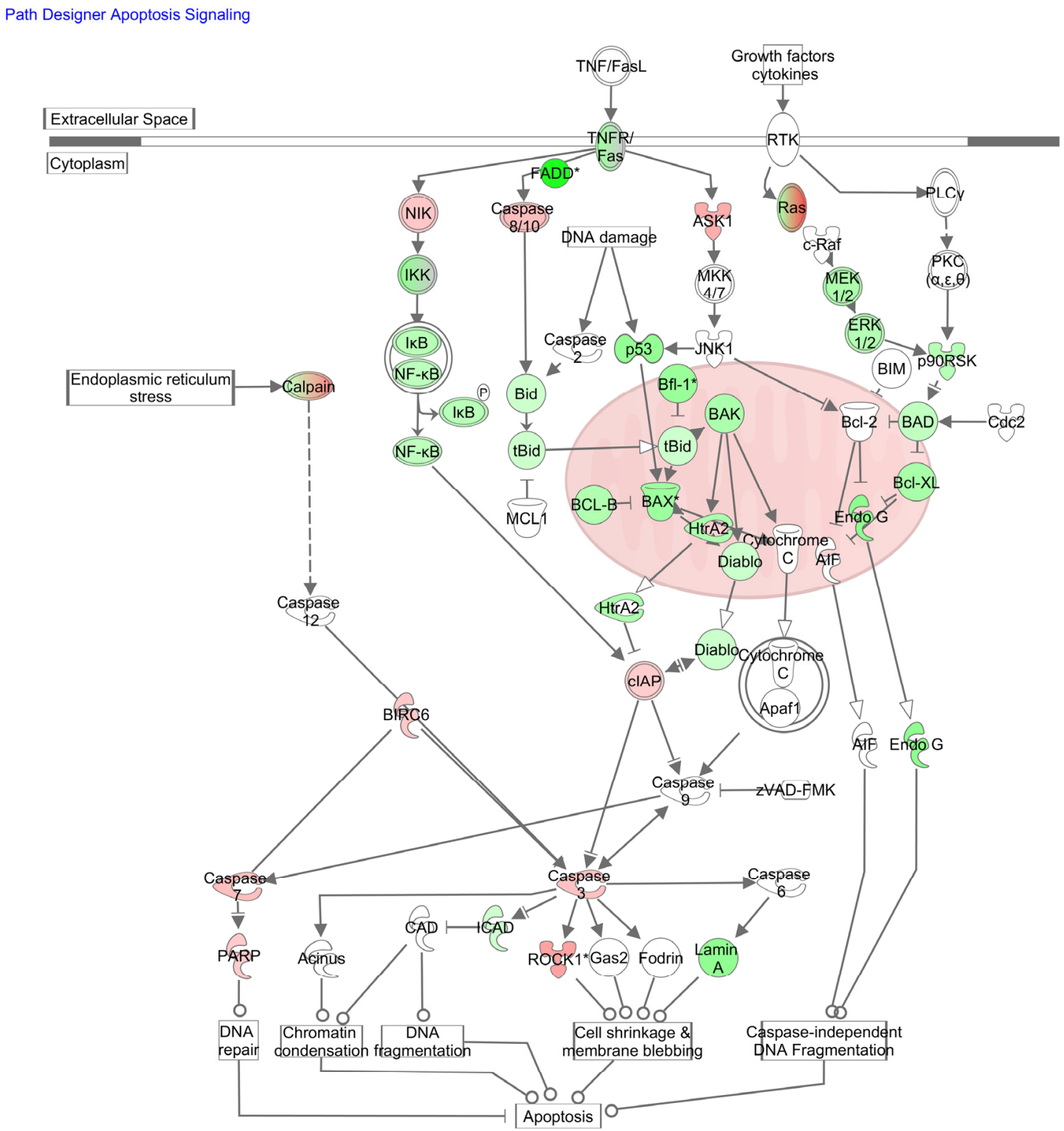

(c) 2000-2012 Ingenuity Systems, Inc. All rights reserved.

Figura 17: Via de sinalização da apoptose gerada pelo software Ingenuity Pathway Analysis quando comparamos as células-tronco hematopoéticas de pacientes com esclerose múltipla à células controle. As cores verde e vermelha representam, respectivamente, repressão ou indução da expressão gênica nas células-tronco hematopoéticas dos pacientes, em comparação às células controle. A intensidade das cores é proporcional à razão de expressão (fold change) entre os sinais obtidos nos microarrays.

\subsection{CÉLULAS ESTROMAIS MESENQUIMAIS MULTIPOTENTES}

\subsubsection{CARACTERIZAÇÃO MORFOLÓGICA, IMUNOFENOTÍPICA E CAPACIDADE DE DIFERENCIAÇÃO MULTIPOTENCIAL}

As CTMs isoladas de pacientes com EM apresentaram aderência ao plástico e morfologia fibroblastoide (afilada e alongada), semelhante às células isoladas de doadores saudáveis de medula óssea. No entanto, as CTMs isoladas de pacientes pré- e póstransplante apresentaram aparência senescente (aparência de CTMs saudáveis cultivadas 
por diversas passagens) e crescimento lento [tempo de confluência mais longo (6-7 dias) em relação às CTMs saudáveis (3-4 dias)] até a terceira passagem. A Figura 18 ilustra imagens obtidas por microscopia de contraste de fase de CTMs isoladas de doador saudável de medula óssea (Figuras 18A e B) e de paciente com EM (Figuras 18C e D).
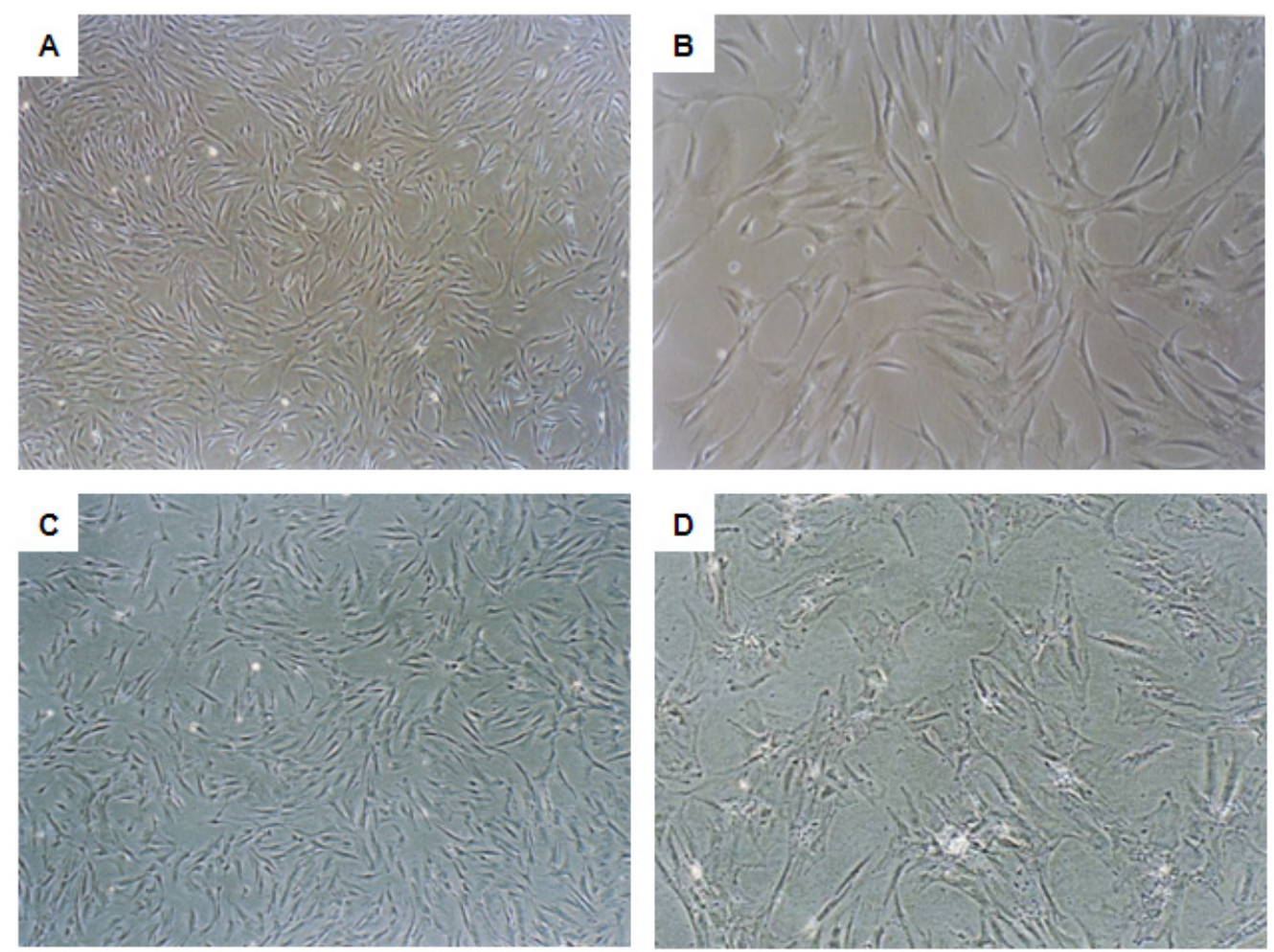

Figura 18: Caracterização morfológica de células estromais mesenquimais de indivíduos saudáveis e de pacientes com esclerose múltipla. Fotos representativas de células estromais mesenquimais (CTMs) isoladas da medula óssea (população de células aderentes fibroblastoides, afiladas) de um doador saudável e de um paciente com esclerose múltipla (EM). CTMs de doador saudável na terceira passagem (aumento 40X em A e 100X em B). CTMs de paciente com EM na terceira passagem (aumento 40X em C e de 100X em D).

Para a caracterização imunofenotípica, as CTMs isoladas de doadores saudáveis de medula óssea e de pacientes pré- e pós-TACTH foram expandidas até a terceira passagem e marcadas com anticorpos monoclonais contra 16 antígenos de superfície e analisadas por citometria de fluxo. Todas as células isoladas de doadores saudáveis e de pacientes pré- e pós-TACTH apresentaram imunofenótipo característico de CTMs, isto é: i) alta expressão de CD90, CD13, CD29, CD105, CD73, CD44, CD166 e HLA-ABC; ii) expressão intermediária de CD146, CD54 e CD106; e iii) baixa expressão de HLA-DR, CD14, CD34, CD31 e CD45. Na Figura 19, os histogramas ilustram CTMs isoladas de um doador saudável, apresentando imunofenótipo característico. 

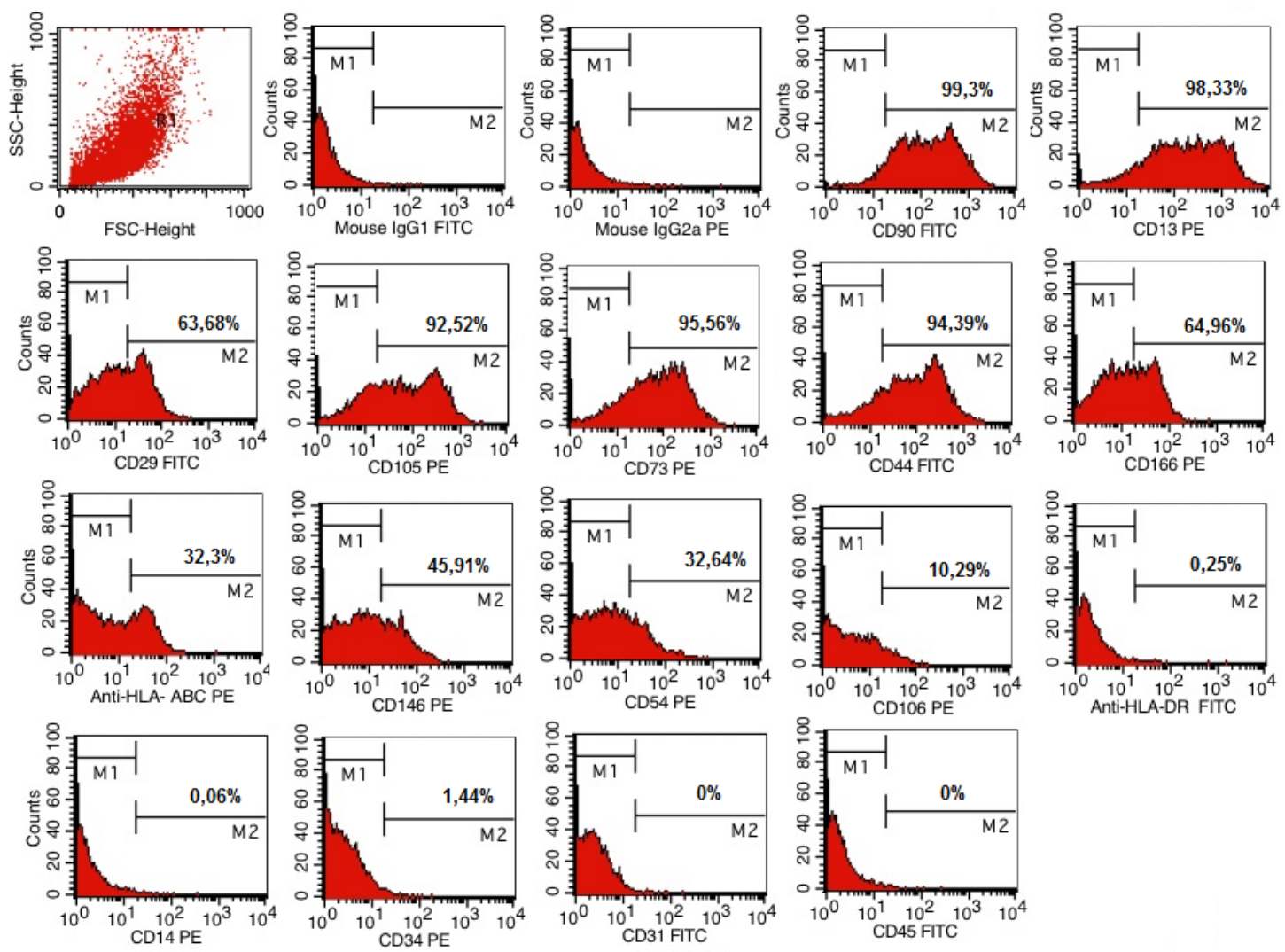

Figura 19: Caracterização imunofenotípica de células estromais mesenquimais isoladas de doador saudável de medula óssea. Células estromais mesenquimais em terceira passagem foram marcadas com anticorpos monoclonais e analisadas por citometria de fluxo. Os diversos marcadores foram analisados usando-se marcações simples. Para análise, foi desenhada uma gate na população de células viáveis (R1), estabelecida com base nos parâmetros de tamanho (FSC) e granularidade (SSC).

Embora todas as CTMs isoladas de controles e pacientes tenham apresentado imunofenótipo característico, encontramos diferenças significantes nas porcentagens de células positivas de alguns antígenos de superfície. Foi observada diminuição significante $(P$ $<0,05$ para todas as comparações) da expressão de CD29 (pré-Tx=79,25 $\pm 3,41 \%$; pós$\mathrm{Tx}=76,41 \pm 4,47 \%$ ), CD105 (pré-Tx=58,70 $\pm 7,43 \%$; pós-Tx=53,52 $\pm 7,64 \%$ ), CD73 (pré$\mathrm{Tx}=67,84 \pm 4,82 \%$; pós-Tx=69,30 \pm 3,55\%) e CD44 (pré-Tx=65,92 $\pm 5,29 \%$; pós-Tx=61,58 \pm $6,42 \%$ ) nas CTMs dos pacientes (pré- e pós-TACTH) em relação às CTMs dos controles (CD29=90,42 $\pm 2,0 \%$; CD105=88,68 \pm 1,40\%; CD73=84,73 $\pm 2,72 \%$; CD44=84,90 $\pm 1,80 \%$ ).

Da mesma forma, foi observada diminuição significante da expressão de CD166 (49,37 \pm 6,68\%), HLA-ABC (70,03 \pm 4,35\%) e CD146 (21,91 \pm 5,48\%) nas CTMs dos pacientes pósTACTH em relação às CTMs controles $(C D 166=72,66 \pm 3,46 \%$; HLA-ABC=70,03 $\pm 4,35 \%$; CD146=42,61 $\pm 7,38 \%)(P<0,05$ para todas as comparações). Não foram encontradas diferenças significantes entre as porcentagens de células positivas para os antígenos de superfície CD90, CD13, CD54, CD106, HLA-DR, CD14, CD34, CD31 e CD45, quando 
comparamos as CTMs isoladas dos controles e as dos pacientes pré- e pós-TACTH (Figura 20).

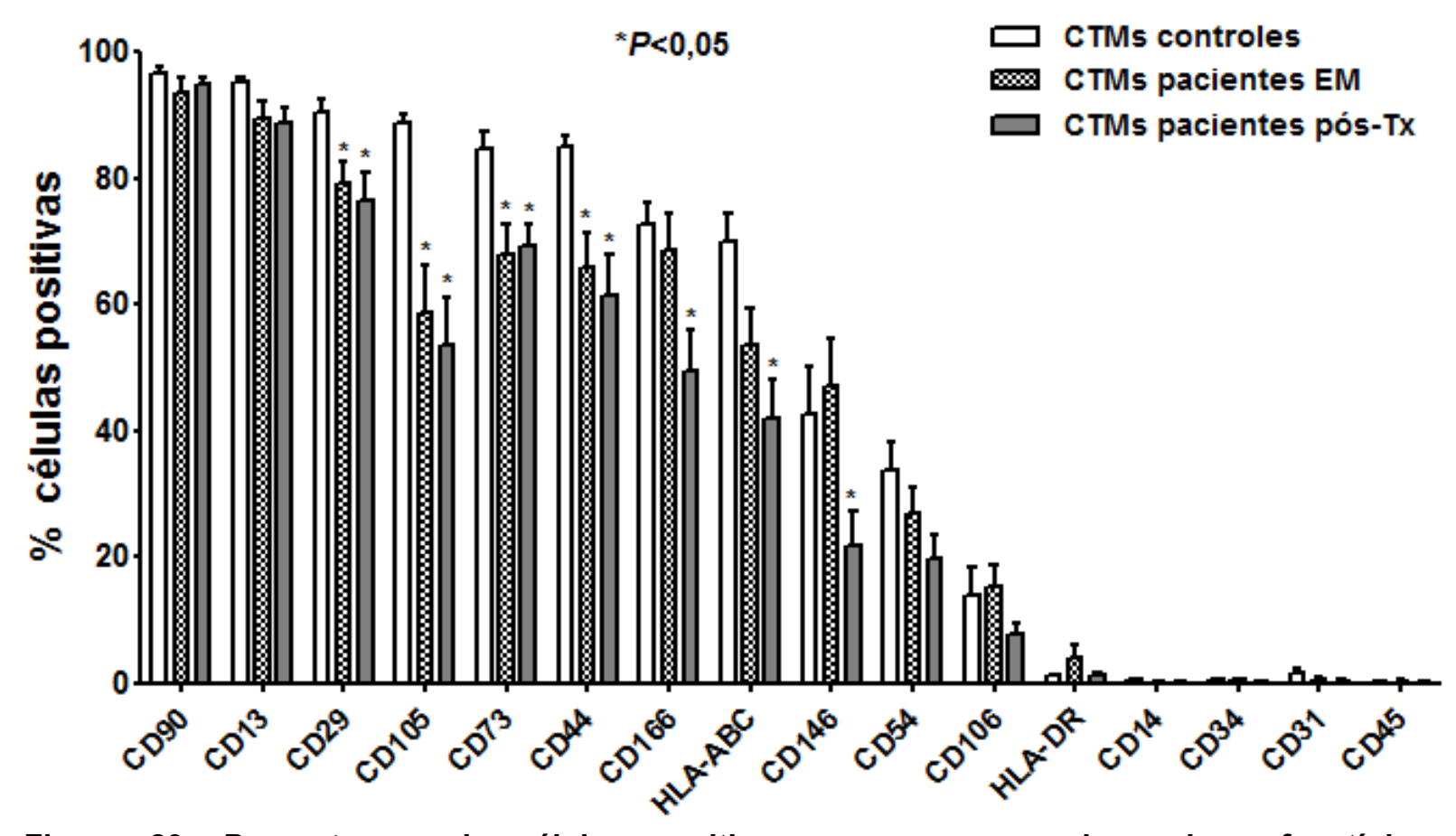

Figura 20: Porcentagem de células positivas para os marcadores imunofenotípicos característicos expressos nas células mesenquimais estromais de indivíduos saudáveis e de pacientes com esclerose múltipla pré- e pós-transplante.

Como descrito anteriormente, as CTMs isoladas da medula óssea de doadores saudáveis e pacientes pré- e pós-transplante monstraram capacidade de aderência ao plástico, morfologia fibroblastoide e expressão dos principais marcadores imunofenotípicos. Além disso, avaliamos a capacidade de diferenciação das CTMs isoladas de doadores saudáveis e pacientes em células da linhagem mesodérmica (adipócitos e osteócitos).

$\mathrm{Na}$ terceira passagem, CTMs isoladas de doadores saudáveis e de pacientes com EM foram induzidas à diferenciação com meios específicos conforme descrito em Material e Métodos. A Figura 21 mostra a capacidade de diferenciação de CTMs isoladas da medula óssea de doadores saudáveis e pacientes com EM em adipócitos e osteócitos. A adipogênese é demonstrada pela formação de vacúolos lipídicos corados com Sudan IIescarlate e a osteogênese é demonstrada pela deposição de matriz mineralizada revelada pela coloração de von Kossa. Não foram observadas diferenças grosseiras em relação à capacidade de diferenciação adipogênica e osteogênica quando comparamos as CTMs isoladas de pacientes e doadores saudáveis (Figura 21). 

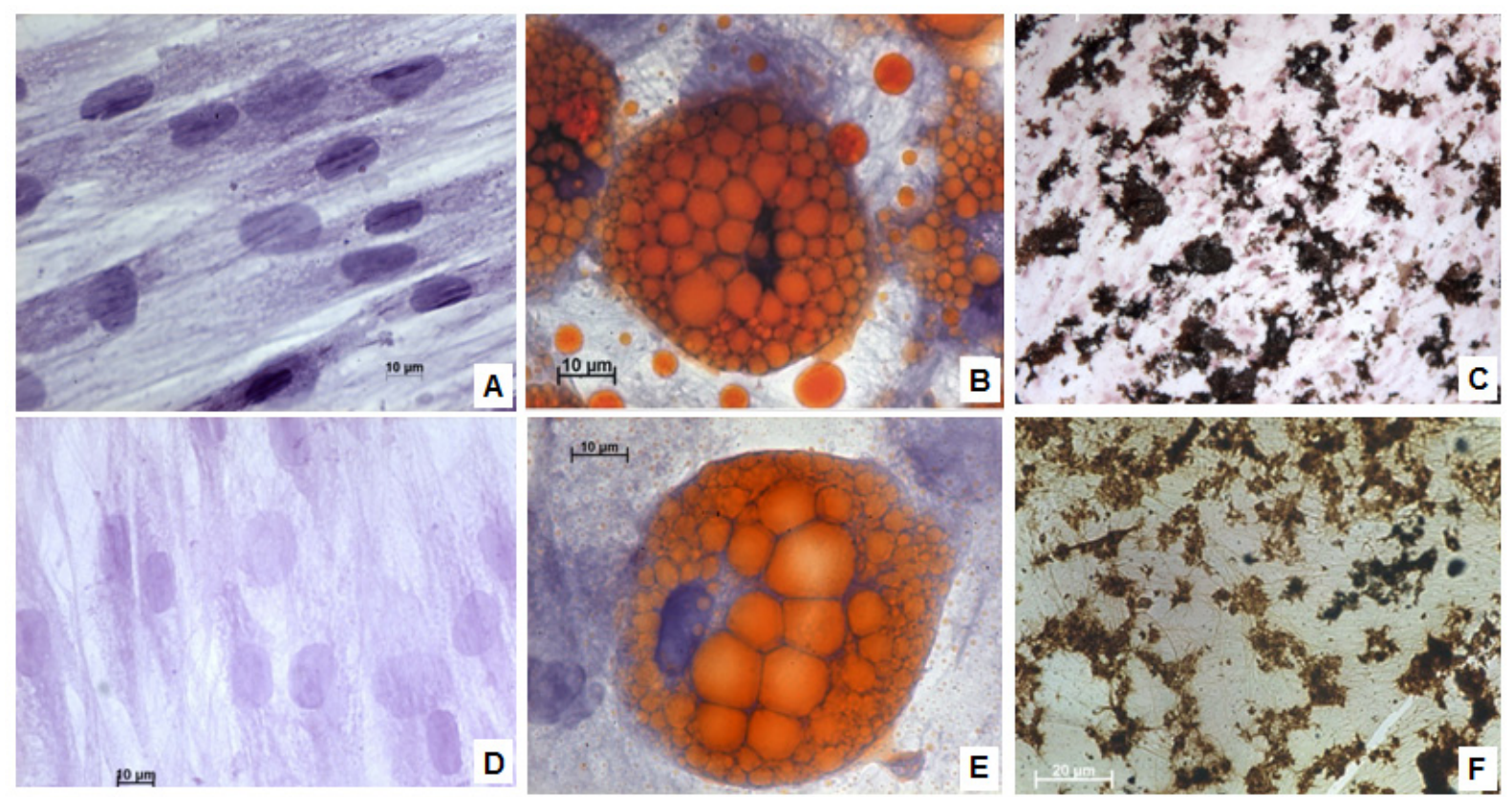

Figura 21: Diferenciação de células estromais mesenquimais de indivíduos saudáveis e pacientes com esclerose múltipla em adipócitos e osteócitos. A) Células estromais mesenquimais (CTMs) de doadores saudáveis indiferenciadas, controle negativo (aumento 630x). B) CTMs de doadores saudáveis diferenciadas em adipócitos, corados com Sudan II-escarlate (aumento 630x). C) CTMs de doadores saudáveis diferenciadas em osteócitos, coloração de von Kossa (aumento 630x). D) CTMs de pacientes com esclerose múltipla (EM) indiferenciadas, controle negativo (aumento 630x). E) CTMs de pacientes com EM diferenciadas em adipócitos, corados com Sudan II-escarlate (aumento 630x). F) CTMs de pacientes com EM diferenciadas em osteócitos, coloração de von Kossa (aumento 630x).

\subsubsection{ANÁLISE DA EXPRESSÃO GÊNICA DIFERENCIAL}

Os mesmos parâmetros de qualidade dos microarrays utilizados para as CTHs foram novamente realizados para as CTMs e, em resumo, esses parâmetros de hibridação analisados foram satisfatórios e, os dados de expressão gênica das amostras de CTMs obtidos foram utilizados de forma segura.

Além disso, observamos a qualidade dos dados extraídos na Figura 22, vista pela distribuição de massas concentradas no eixo zero, indicando ótima qualidade da intensidade de sinal dos microarrays hibridados. Adicionalmente, as amostras foram submetidas à análise de componente principal (PCA - Principal Component Analysis), gerando gráfico com a dispersão espontânea das amostras utilizadas nas hibridações. Como observamos na Figura 23, as amostras de CTMs isoladas de doadores saudáveis agruparam de forma consistente, com proximidade maior entre as amostras (em vermelho). Em contrapartida, as amostras de CTMs isoladas de pacientes, tanto do período pré- quanto do período pósTACTH, tiveram maior dispersão (verde-pré-TACTH; azul-pós-TACTH). 


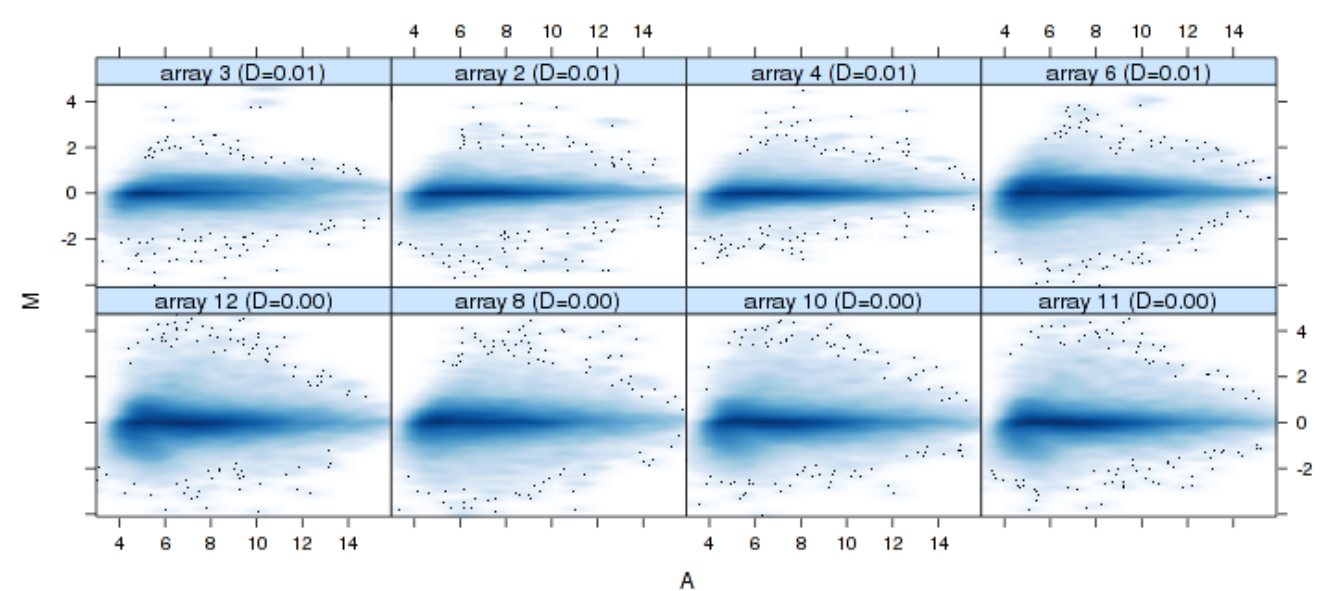

Figura 22: MA plots representando os dados de intensidade de fluorescência dos microarrays. O MA plot calcula a razão entre a intensidade de sinal de cada microarray (representado no eixo x) e a intensidade de sinal gerada pela mediana dos sinais de todos os microarrays (representada no eixo y).

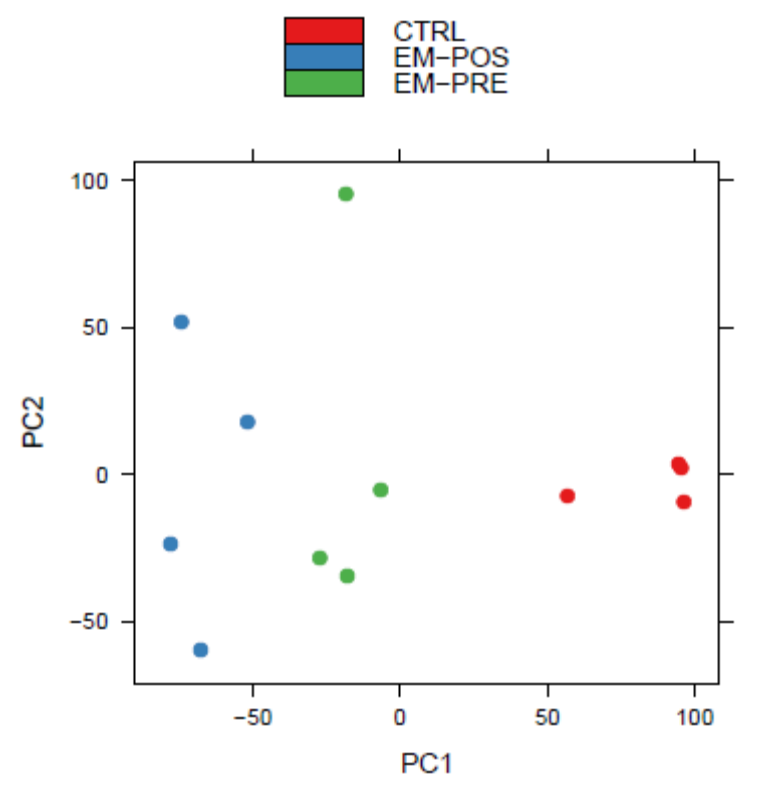

Figura 23: Dispersão espontânea das amostras de células estromais mesenquimais hibridadas nos microarrays por meio da análise de componente principal. As amostras de CTMs hibridadas nos microarrays estão representadas pelos pontos no gráfico. As amostras de CTMs isoladas de doadores saudáveis de medula óssea estão representadas em vermelho, as amostras de CTMs de pacientes com EM pré-TACTH estão representadas em verde e pós-TACTH, em azul.

Após análise dos parâmetros de qualidade dos dados extraídos, os dados de expressão gênica foram filtrados e normalizados, permitindo a comparação e correlação da expressão gênica entre os grupos de CTMs isoladas de doadores saudáveis e pacientes com EM pré- e pós-TACTH. Observamos que os microarrays de cada grupo apresentaram normalização adequada, conforme verificado pelas posições e larguras similares das caixas de normalização, mostradas na Figura 24. 


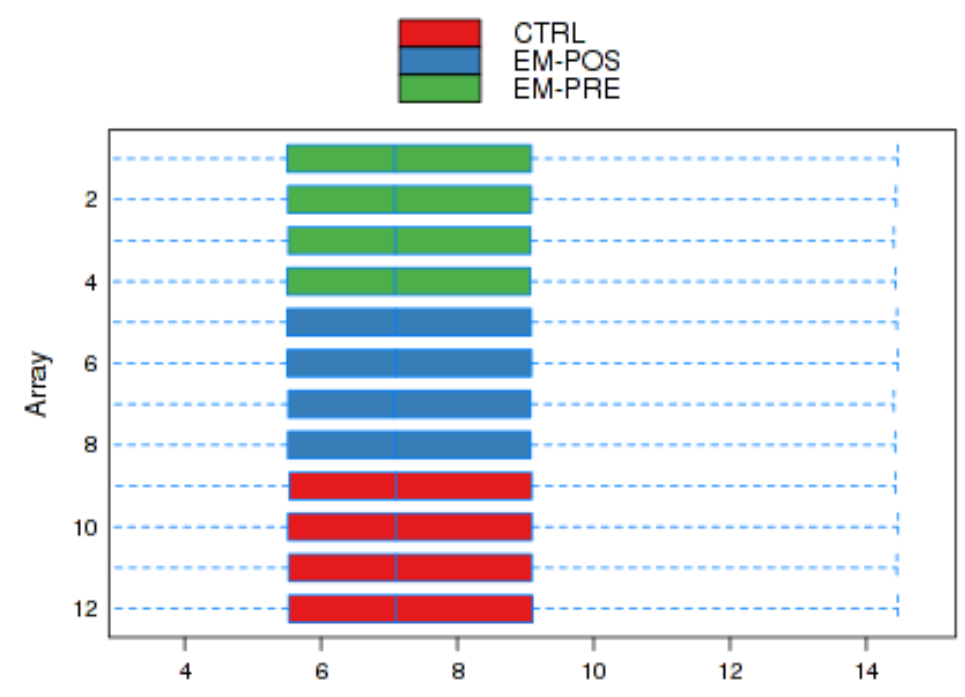

Figura 24: Normalização dos dados de expressão gênica das células estromais mesenquimais isoladas de doadores saudáveis e de pacientes com esclerose múltipla nos períodos pré- e pós-transplante. O Box plot mostrado representa o sumário de distribuição dos valores de intensidade de fluorescência normalizados para cada grupo de microarrays, sendo que cada Box corresponde a um microarray.

Após as etapas de pré-processamento e normalização, os dados foram submetidos ao agrupamento hierárquico simples, com o objetivo de analisá-los de acordo com o perfil de similaridade gênica. A Figura 25 demonstra a clusterização hierárquica euclideana simples dos dados de expressão gênica das CTMs isoladas de doadores saudáveis e de pacientes pré- e pós-TACTH.

Por meio da clusterização hierárquica, podemos observar que existem diferenças no perfil de expressão gênica entre os agrupamentos formados pelas amostras de doadores saudáveis (CTRL.NM16.454.1.1; $\quad$ CTRL.NM27.454.1.2; $\quad$ CTRL.NM19.454.1.3 e CTRL.NM20.454.1.4) e de pacientes pré- e pós-TACTH, mas que, ainda assim, as amostras isoladas de pacientes no período pré-TACTH (EM-PRE.EM03.130.1.1; EMPRE.EM15.130.1.2; EM-PRE.EM19.130.1.3 e EM-PRE.EM24.130.1.4) estão reunidas em agrupamento diferente das amostras desses mesmos pacientes no período pós-TACTH (EM-POS.EM03.131.1.1; $\quad$ EM-POS.EM15.131.1.2; $\quad$ EM-POS.EM19.131.1.3 e EMPOS.EM24.131.1.4), indicando que existe perfil diferente após o transplante. 


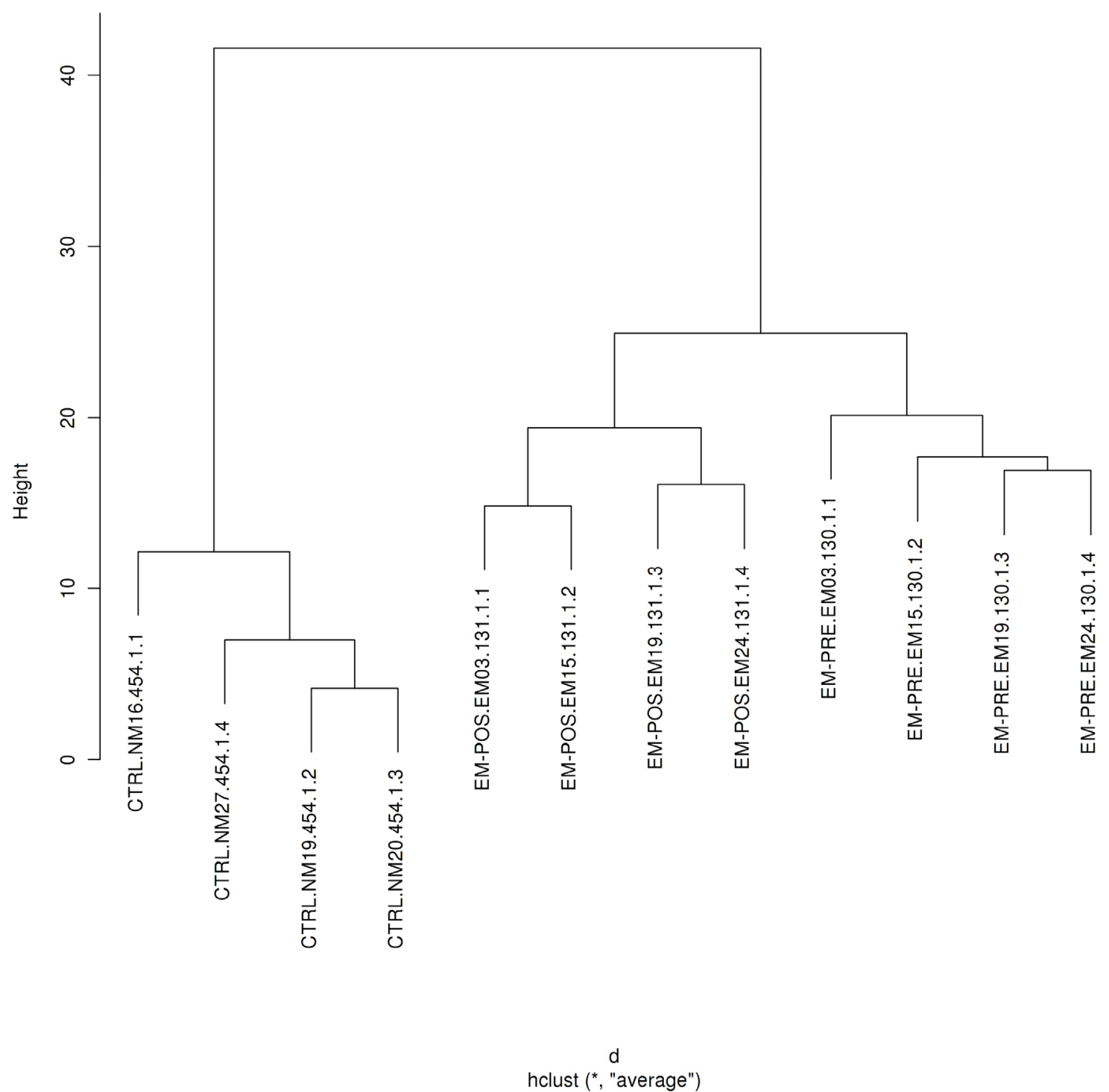

Figura 25: Clusterização hierárquica euclideana simples dos dados de expressão gênica das células estromais mesenquimais isoladas de doadores saudáveis e de pacientes com esclerose múltipla nos períodos pré- e pós-transplante. Os dendogramas foram gerados através da plataforma $R$ pela análise da expressão das sondas de maior variância de expresssão.

Uma vez que foram observadas diferenças nos perfis de expressão gênica entre as CTMs isoladas de doadores saudáveis e pacientes com EM, através das análises de agrupamento hierárquico, partimos para a fase de identificação dos genes diferencialmente expressos. Primeiramente, avaliamos a expressão diferencial entre as CTMs isoladas de doadores saudáveis e pacientes do período pré-transplante e depois avaliamos os genes diferencialmente expressos entre as CTMs isoladas dos pacientes pré- em relação ao pósTACTH.

Dessa forma, considerando o fold change $\geq 2,0$ e $P<0,01$, foi possível identificar um total de 618 genes diferencialmente expressos nas CTMs de pacientes com EM do pré- 
TACTH em comparação as células dos doadores saudáveis. Dentre os 618 genes, 370 encontravam-se induzidos e 248 genes estavam reprimidos nas CTMs dos pacientes em relação aos controles, como mostrado no Volcano plot (Figura 26A). Podemos observar as diferenças de genes reprimidos e induzidos nas células dos pacientes em relação aos controles no heatmap gerado pela clusterização supervisionada após análise estatística (Figura 27).

Com relação à comparação do perfil de expressão gênica das CTMs de pacientes pré-TACTH em relação a esses mesmos pacientes após o transplante, foram encontrados um total de 81 genes diferencialmente expressos nas células dos pacientes após o transplante. Foram encontrados 77 genes com expressão induzida e quatro genes com expressão reprimida (Figura 26B).
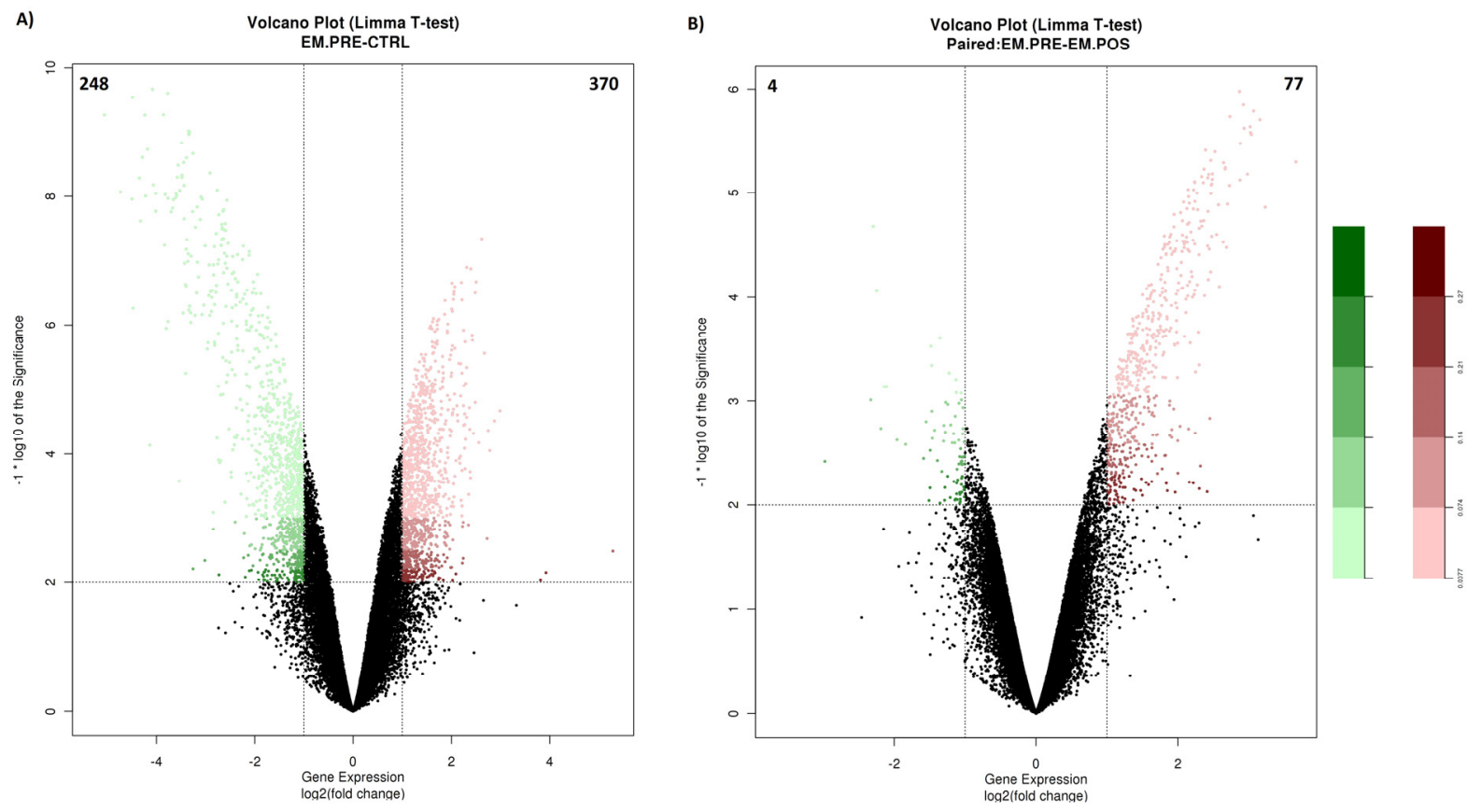

Figura 26: Grupo de genes diferencialmente expressos nas células estromais mesenquimais (A) de pacientes com esclerose múltipla em comparação às células controle, e (B) nas células estromais mesenquimais de pacientes pós-transplante em comparação ao pré-transplante. $O$ Volcano plot demonstra o fold change $\geq 2$ versus a significância estatística $(P<0,01)$ dos dados de expressão gênica, indicando em verde o grupo de genes reprimidos e, em vermelho o grupo de genes induzidos. Em preto o grupo de genes sem alterações na expressão gênica entre os grupos avaliados. 


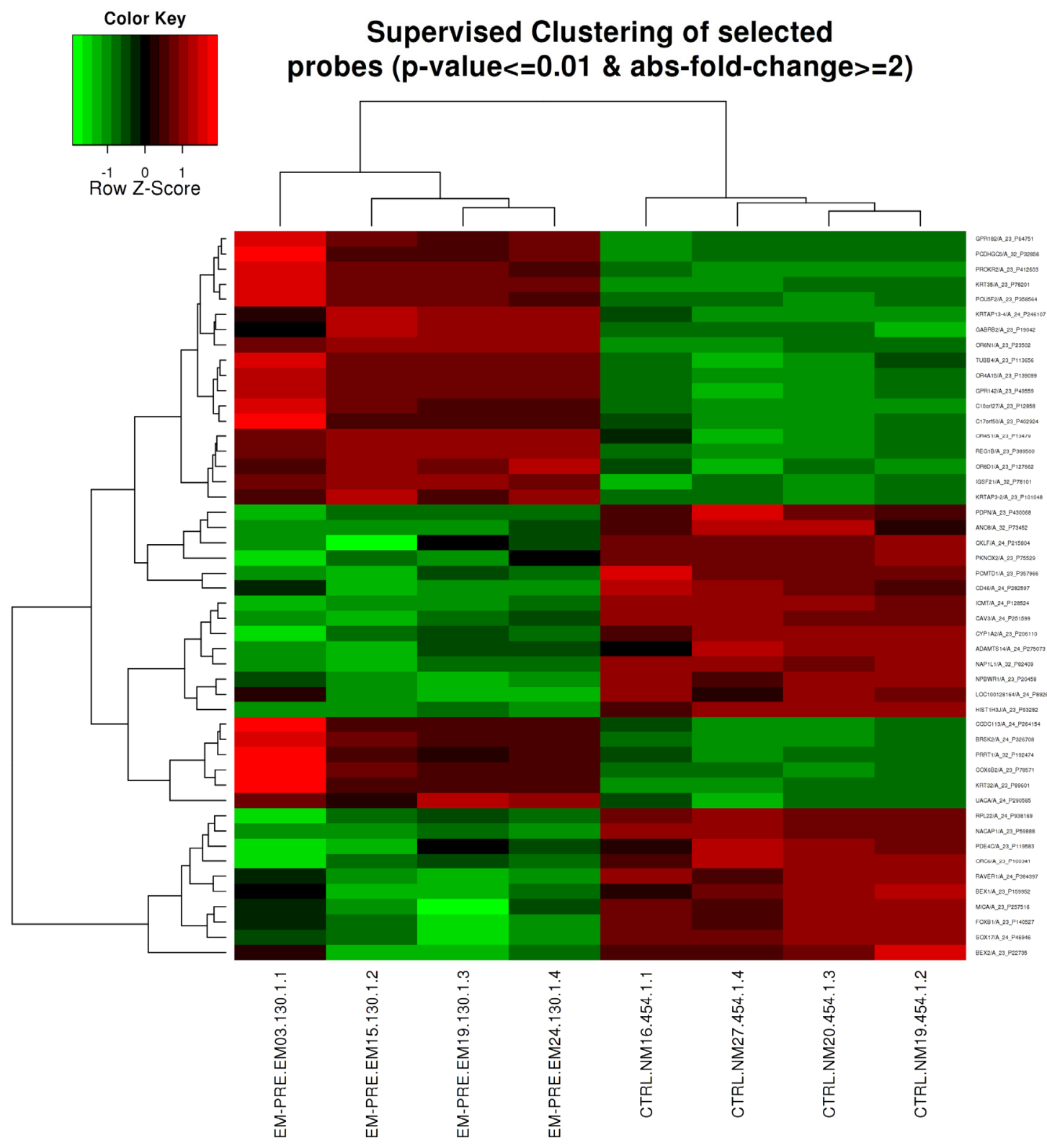

Figura 27: Clusterização hierárquica supervisionada das 100 sondas com maior variância de expressão entre as células estromais mesenquimais isoladas de doadores saudáveis e de pacientes com esclerose múltipla. Os dendogramas foram gerados através da Plataforma $R$ com as 100 sondas de maior variância de expressão entre as amostras.

Além disso, assim como foi realizado para as CTHs, escolhemos algumas categorias, tais como, citocinas/receptores de citocinas, quimiocinas/receptores de quimiocinas, moléculas de adesão e fatores de transcrição para descrever alguns genes diferencialmente expressos nas CTMs dos pacientes do período pré-TACTH em relação às CTMs controles.

Dentro da categoria citocinas/receptores de citocinas, observamos que os genes GDF15, LTA, NRG4, IL1F6, BDNF, IL10, IL6, DDR2 e IL13RA1 estão induzidos nas CTMs dos pacientes em relação às CTMs controles, e os genes IGF2, IL17RD e IL17RE estão reprimidos nas células dos pacientes em relação as CTMs isoladas de doadores saudáveis. 
Com relação às quimiocinas e receptores de quimiocinas, observamos indução da expressão dos genes CCL15 e CCL3L3 e repressão dos genes CKLF, CCL7, CXCL12 e CXCL5 nas CTMs dos pacientes com EM em relação as células controle.

$\mathrm{Na}$ cateoria moléculas de adesão, encontramos indução dos genes $A D A M 21$, IGSF11, ESAM, LAMC3, ITGAL, ITGA9, VTN, CTGF, ALÇAM, COL3A1, COL20A1, ADAMTS13 e ADAMTSL4 e repressão dos genes CDH7, CDH24, COL7A1, ADAMTS7, ADAMTS3, ITGA10 e ADAMTS4 nas células dos pacientes em relação às células controle.

Dentre os fatores de transcrição, observamos indução dos genes POU4F2, HNF1B, HAND1, EPAS1, STAT4, FOXI1, FOXE1, MYOG, NR5A2, GCM1, RB1, STAT5B e IKZF4 e repressão dos fatores SMARCA4, NFIX, EP300, NFIC, ETV1, CREB5, ZNF85, SOLH, ZFP36L2, UHRF1, CDX2, MAFA, LZTS1 e TCF19 nas células dos pacientes em relação CTMs isoladas de doadores saudáveis.

\subsubsection{ENRIQUECIMENTO FUNCIONAL DOS GENES DIFERENCIALMENTE EXPRESSOS}

Após identificação dos genes diferencialmente expressos nas CTMs dos pacientes pré-transplante em relação as CTMs controle, o enriquecimento funcional desses genes foi realizado pelo software David Functional Annotation Bioinformatic Microarray.

Dentre os 370 genes induzidos na relação dos diferencialmente expressos nas CTMs de pacientes pré-TACTH, encontramos alterações significantes na expressão de genes relacionados com processos biológicos, componentes celulares e funções moleculares (categorias do Gene Ontology) como mostra a Figura 28. Com relação às vias de sinalização (KEGG pathways), apenas a sinalização do cálcio (2,7\% dos genes) foi significante dentre os genes induzidos.

Dentro dos 248 genes reprimidos na relação dos diferencialmente expressos nas CTMs de pacientes pré-TACTH, encontramos alterações significantes na expressão de genes relacionados com processos biológicos e funções moleculares (categoria do Gene Ontology) como mostra a Figura 29. Não foram encontrados genes reprimidos dentro da categoria de componentes celulares.

Com relação aos 77 genes induzidos nas CTMs de pacientes pós-TACTH, encontramos alterações significantes na expressão de genes relacionados com processos biológicos e componentes celulares (categorias do Gene Ontology), como mostra a Figura 30. Dentro de funções moleculares, encontramos genes dentro da categoria ligação ao RNA (17,5\% dos genes) e alterações relacionadas aos ribossomos (5,4\% dos genes) (KEGG pathways). 
A)

\section{Processos biológicos}

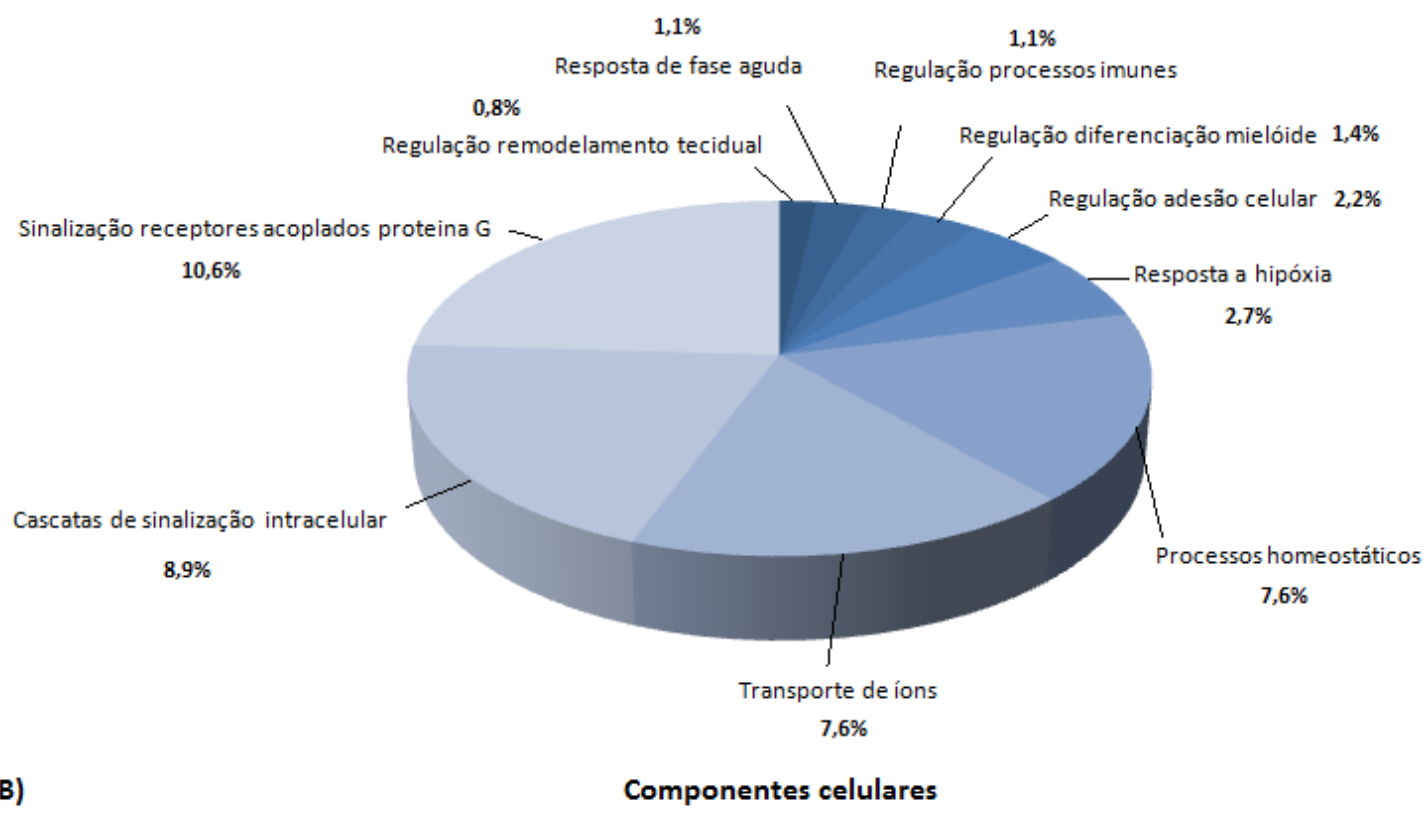

B)

$2,7 \%$

$3 \%$

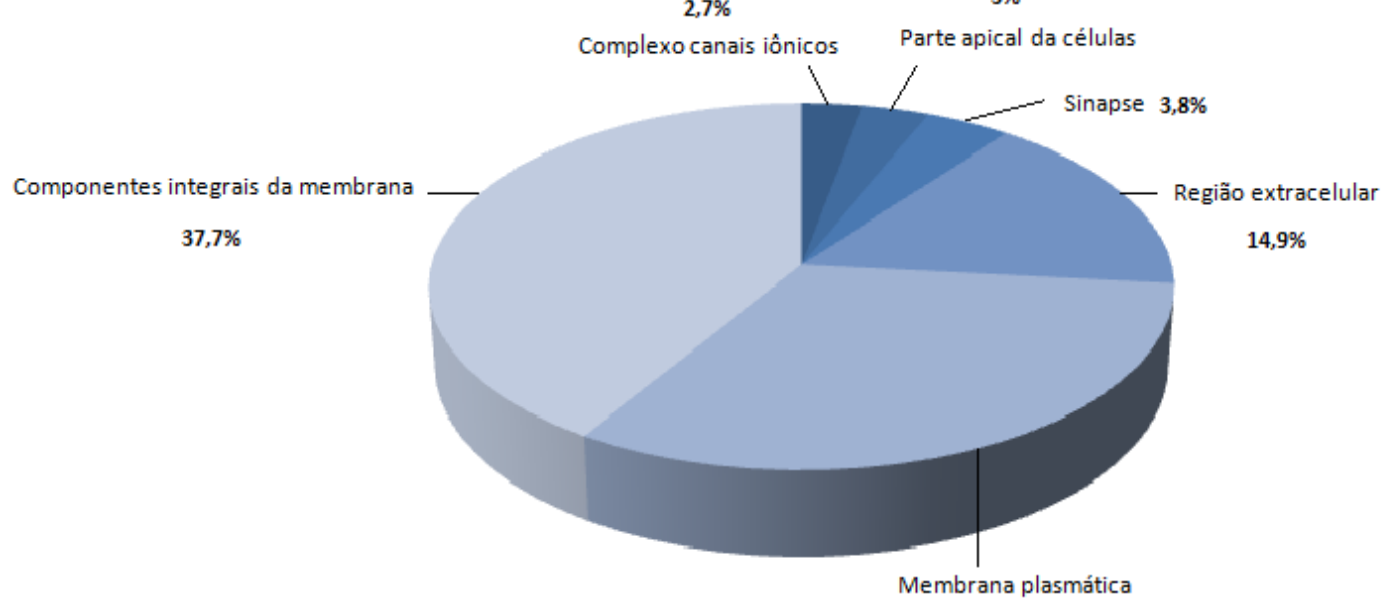

$29,5 \%$

C)

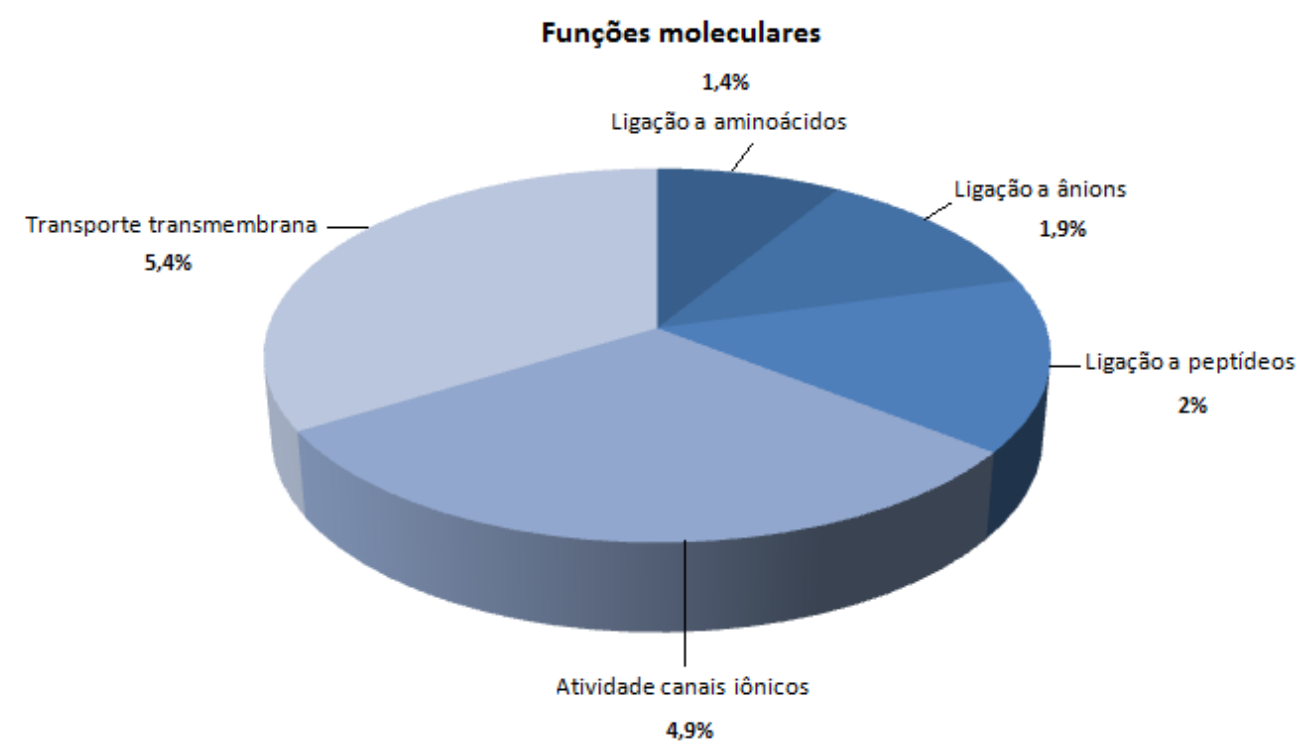

Figura 28: Classificação dos genes induzidos nas células estromais mesenquimais de pacientes com esclerose múltipla em funções biológicas. 
A)

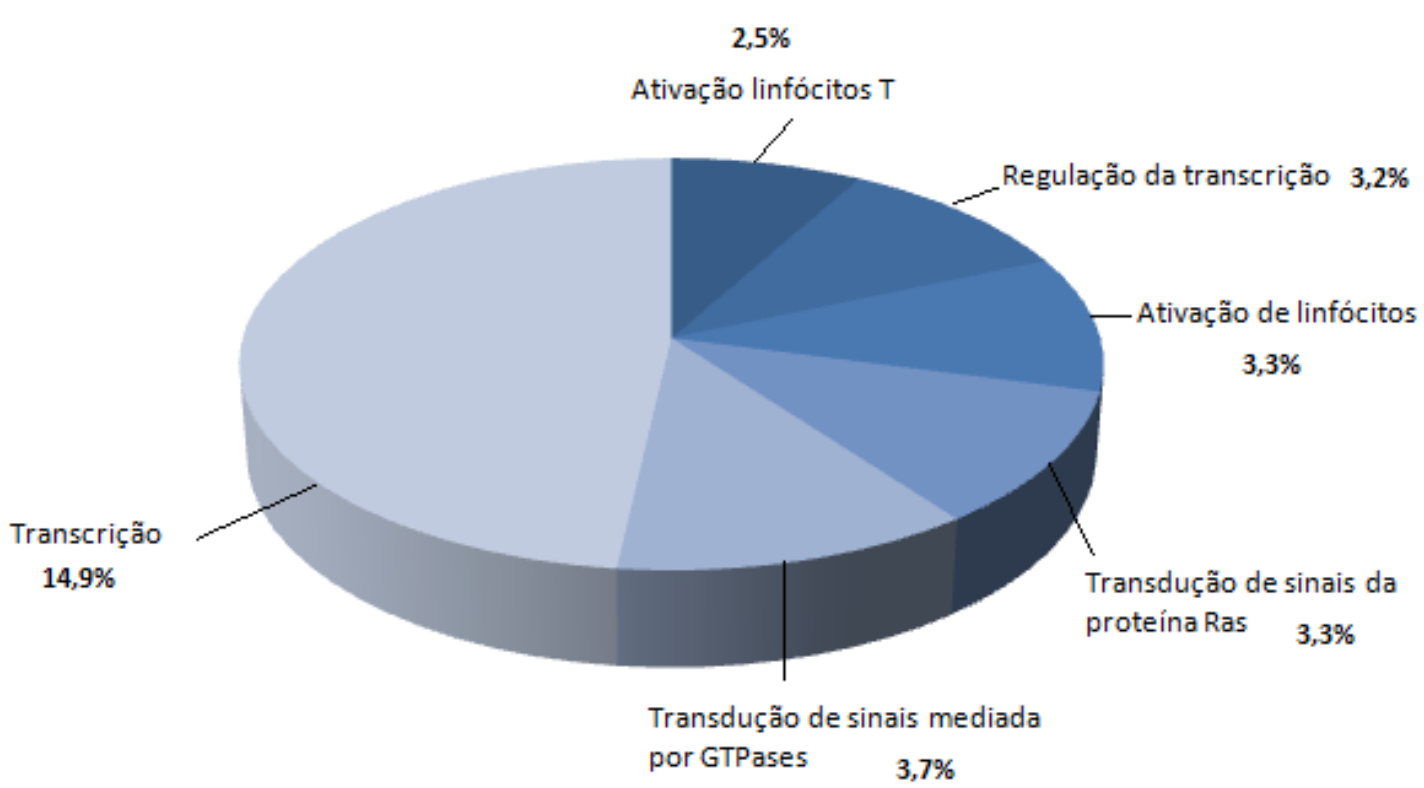

B)

Funções moleculares

$0,8 \%$

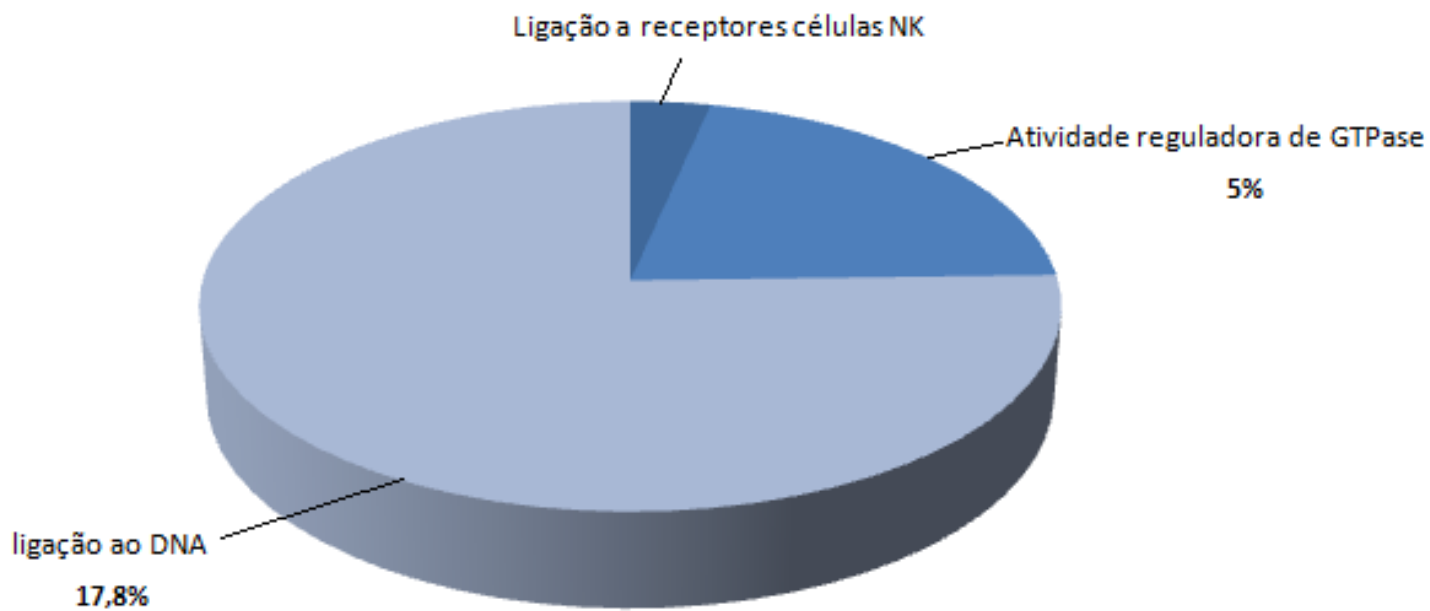

Figura 29: Classificação dos genes reprimidos nas células estromais mesenquimais de pacientes com esclerose múltipla em funções biológicas. 
A)

\section{Processos biológicos}

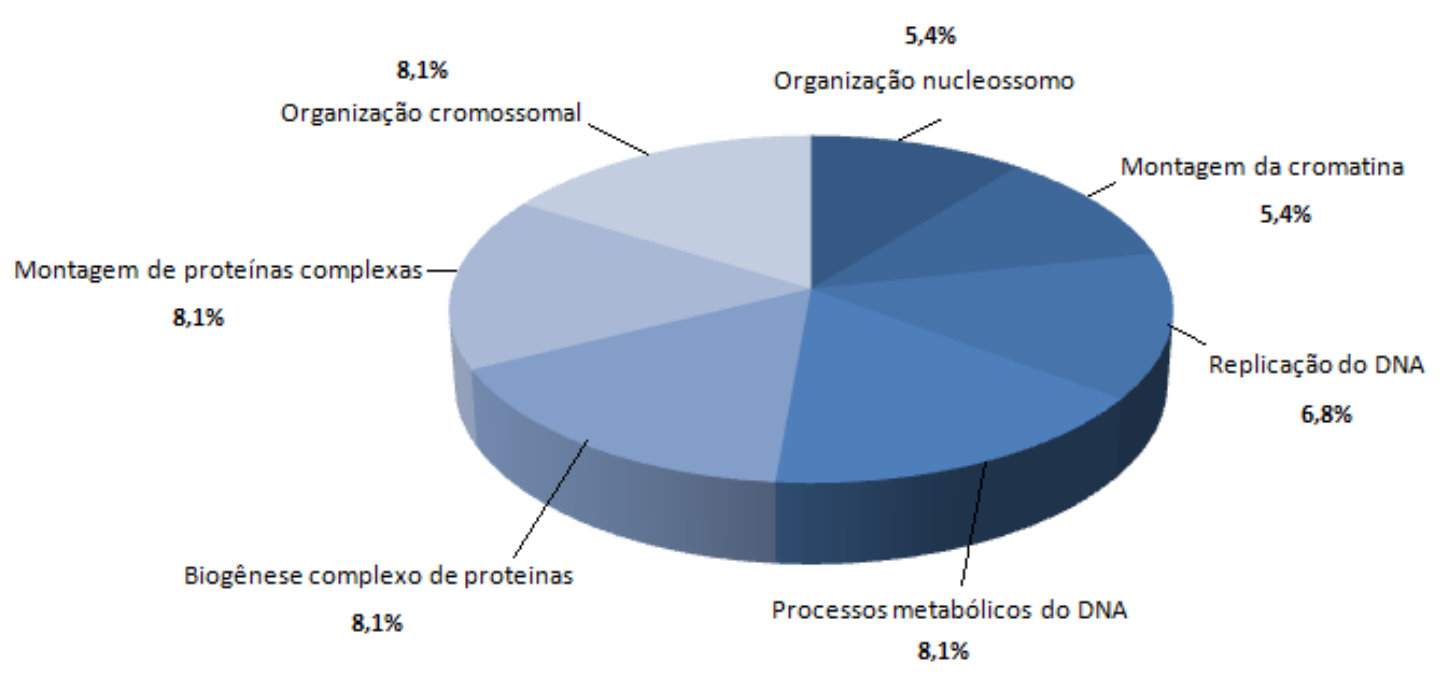

B)

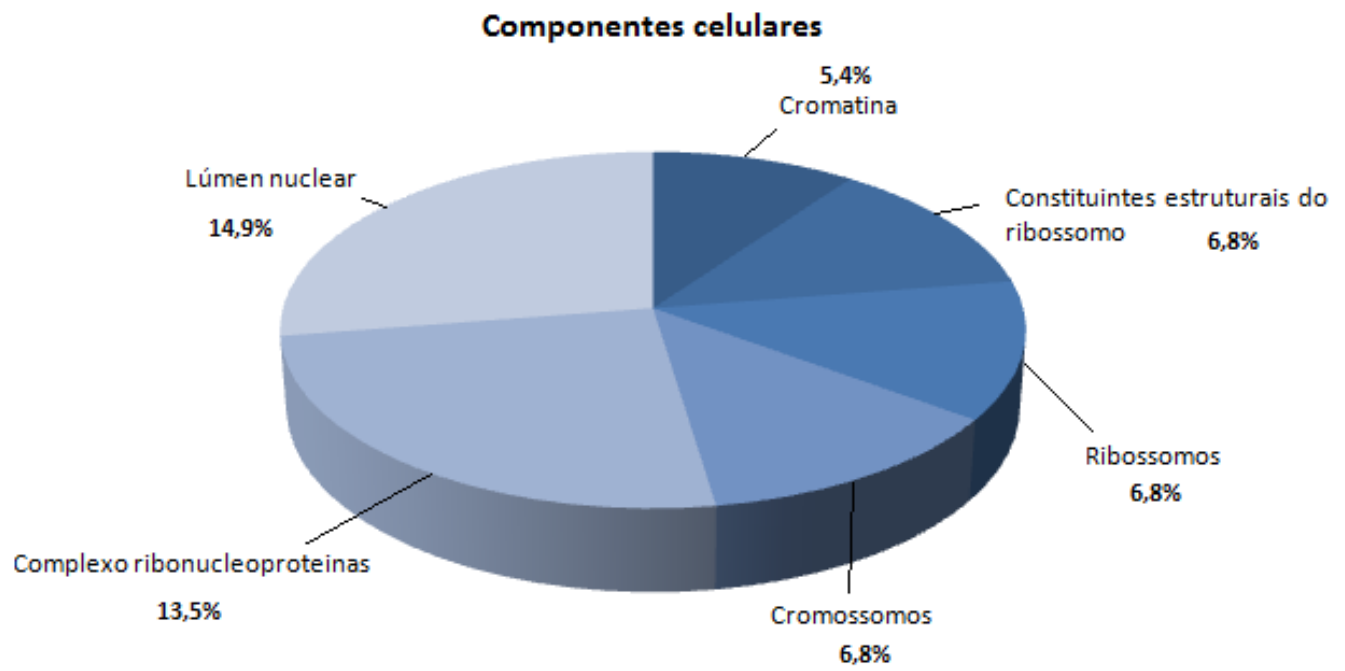

Figura 30: Classificação dos genes induzidos nas células estromais mesenquimais de pacientes com esclerose múltipla pós-transplante em funções biológicas.

\subsubsection{ANÁLISE DE PROCESSOS BIOLÓGICOS SIGNIFICANTES}

Quando realizamos análises por enriquecimento através do GSEA (Gene Set Enrichment Analysis) em busca de processos biológicos significantes dentre as sondas expressas nas CTMs de pacientes e controles, encontramos alguns processos de relevância para nosso estudo. A Tabela 4 mostra alguns desses processos encontrados pelo KEGG pathway e Biocarta quando comparamos as CTMs isoladas de pacientes pré-transplante e controles. A Figura 31 mostra os heatmaps gerados dentro dos processos biológicos significantes escolhidos (citocina/receptores de citocinas e sinalização da IL-10), indicando genes induzidos e reprimidos nas células dos pacientes em relação às células controle. Os asteriscos na frente dos genes indicam que estes estão incluídos na lista dos genes diferencialmente expressos ( $\mathrm{FC} \geq 2 ; P<0,01)$. 
Tabela 4: Conjunto de processos biológicos significantes gerados pelo Gene Set Enrichment Analysis quando comparamos as células estromais mesenquimais de pacientes com esclerose múltipla às células controle.

\begin{tabular}{lccc}
\hline \hline \multicolumn{1}{c}{ Processo biológico } & NES & NORM p-val & FDR q-val \\
\hline \hline 1. KEGG olfactory transduction & 2,65 & 0,000 & 0,000 \\
2. KEGG neuroactive ligand receptor interaction & 2,01 & 0,000 & 0,003 \\
3. KEGG autoimmune thyroid disease & 1,87 & 0,000 & 0,012 \\
4. KEGG graft versus host disease & 1,83 & 0,002 & 0,017 \\
5. KEGG type I diabetes mellitus & 1,82 & 0,000 & 0,014 \\
6. KEGG hematopoietic cell lineage & 1,77 & 0,000 & 0,022 \\
7. KEGG allograft rejection & 1,68 & 0,009 & 0,052 \\
8. KEGG toll-like receptor signaling pathway & 1,59 & 0,005 & 0,121 \\
9. KEGG steroid hormone biosynthesis & 1,57 & 0,016 & 0,138 \\
10. KEGG calcium signaling pathway & 1,56 & 0,003 & 0,137 \\
11. KEGG cytokine-cytokine-receptor interactions & 1,53 & 0,004 & 0,161 \\
12. KEGG taste transduction & 1,52 & 0,024 & 0,156 \\
13. KEGG regulation of autophagy & 1,47 & 0,048 & 0,228 \\
14. KEGG cell adhesion molecules CAMS & 1,46 & 0,013 & 0,215 \\
15. KEGG JAK-STAT signaling pathway & 1,45 & 0,019 & 0,224 \\
16. BIOCARTA IL10 pathway & 1,63 & 0,012 & 0,217 \\
\hline \hline
\end{tabular}

NES: escore de enriquecimento do processo biológico; NORM $P$-valor: valores de $P$ normalizados; FDR $q$-val: taxa de falsa descoberta. 
A) Cytokine-cytokine receptor

interactions

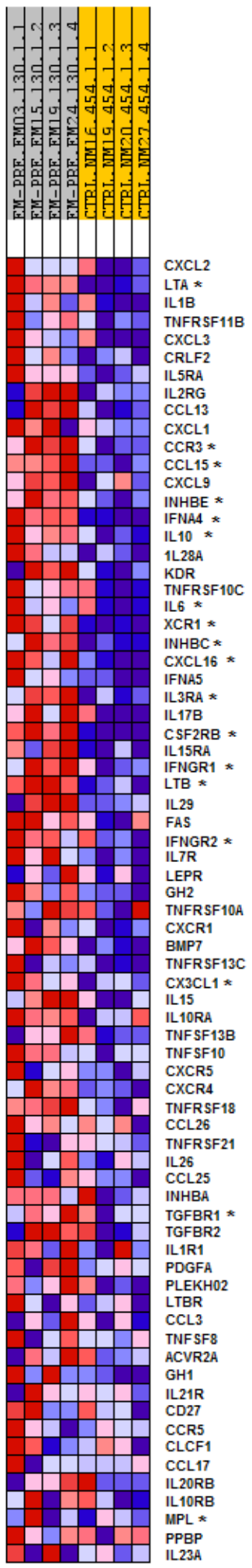

B) IL-10 pathway

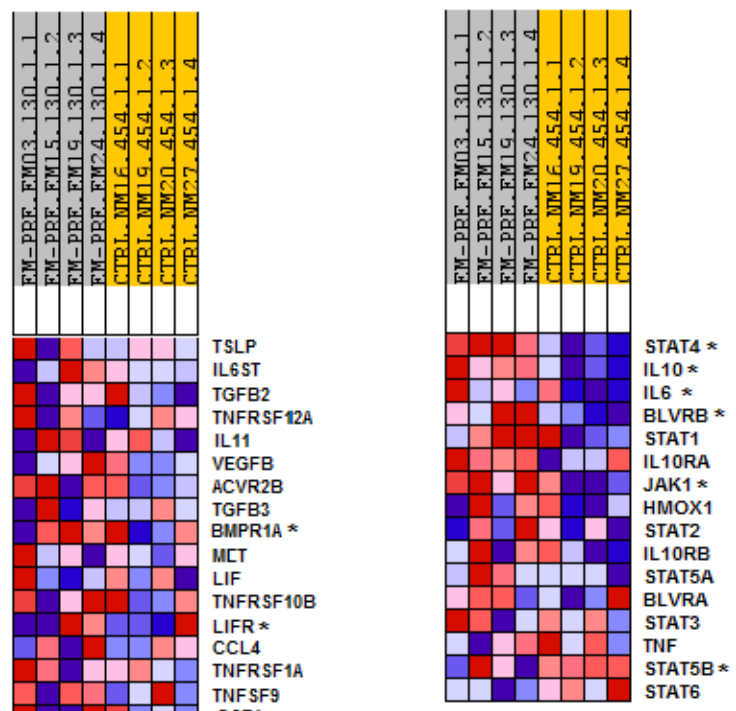

Figura 31: Heatmaps gerados pelo Gene Set Enrichment Analysis contendo genes enriquecidos dentro dos processos biológicos significantes quando comparamos as células estromais mesenquimais de pacientes com esclerose múltipla às células controle. $A$ ) Interações citocina-receptores de citocinas; B) Sinalização da IL-10. 


\subsubsection{ANÁLISE DE VIAS DE SINALIZAÇÃO CANÔNICAS SIGNIFICANTES}

A comparação entre o perfil de expressão gênica das CTMs isoladas de pacientes com EM pré-transplante e de doadores saudáveis revelou alterações significantes em genes pertencentes a vias de sinalização canônicas importantes, como a sinalização do FGF $(P=4,69 \mathrm{e}-02)$ e HGF $(P=4,80 \mathrm{e}-02)$ (Figuras 32 e 33).

No entanto, quando comparamos as CTMs isoladas de pacientes pré-transplante ao período pós-TACTH, não encontramos alterações significantes em nenhuma via de sinalização.

FGF Signaling

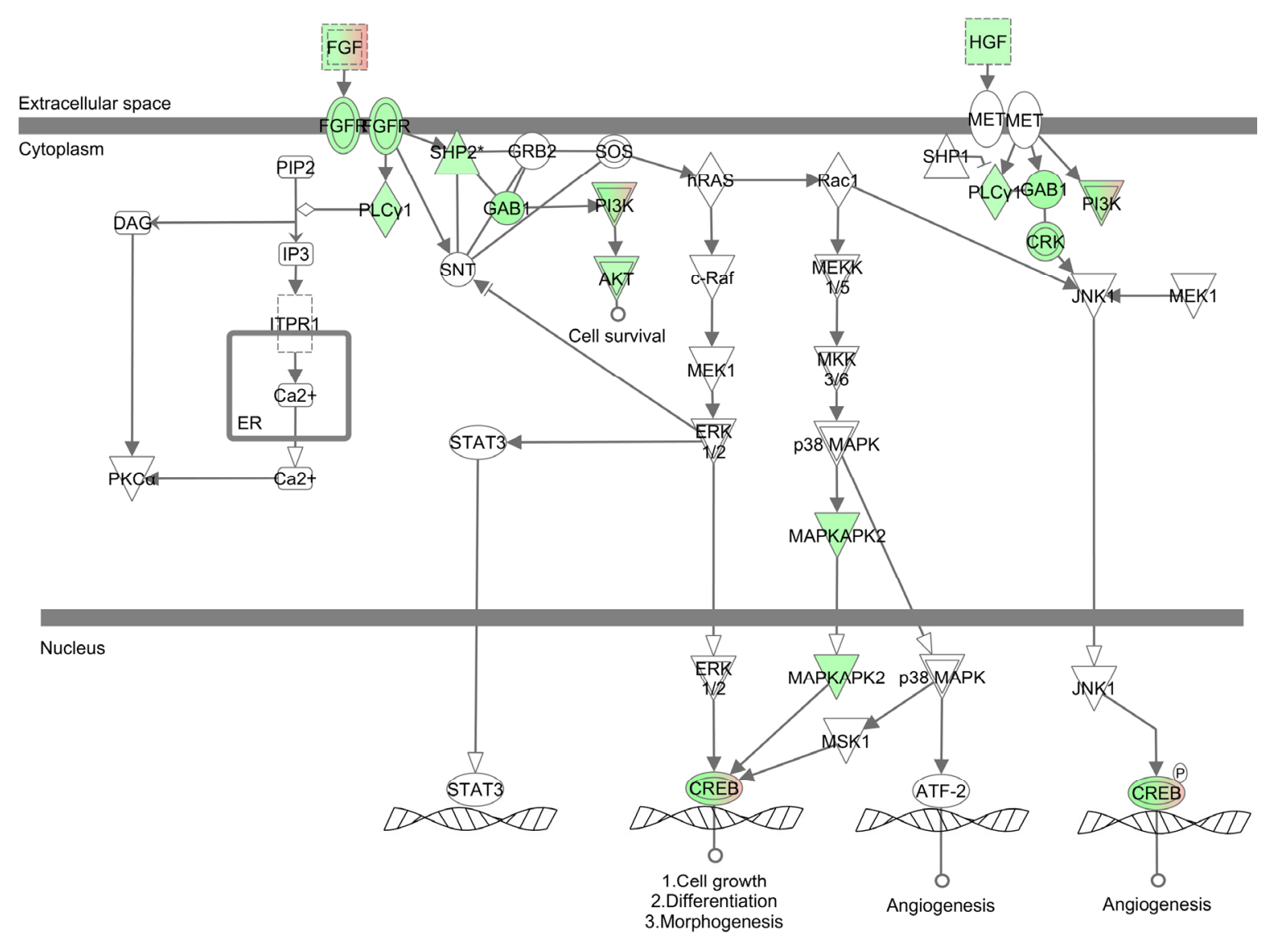

(0) 2000-2012 Ingenuity Systems, Inc. All rights reserved.

Figura 32: Via de sinalização do FGF gerada pelo Software Ingenuity Pathway Analysis quando comparamos as células estromais mesenquimais isoladas de pacientes com esclerose múltipla às células controle. As cores verde e vermelha representam, respectivamente, repressão ou indução da expressão gênica nas células estromais mesenquimais (CTMs) dos pacientes com esclerose múltipla, em comparação as CTMs isoladas de doadores saudáveis. A intensidade é proporcional à razão (fold change) de expressão entre os sinais obtidos nos microarrays. 


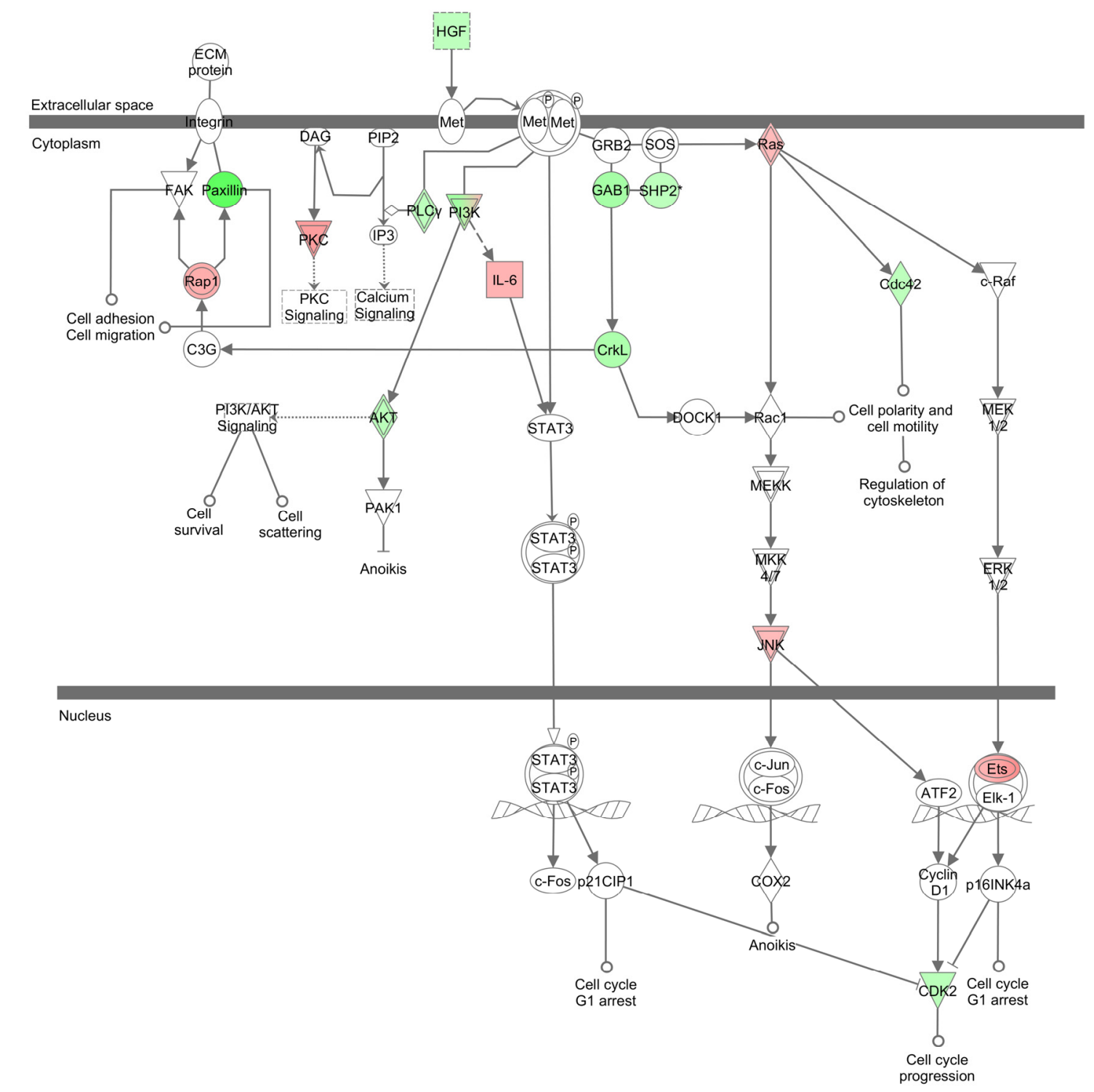

(ㄱ) 2000-2012 Ingenuity Systems, Inc. All rights reserved.

Figura 33: Via de sinalização do HGF gerada pelo Software Ingenuity Pathway Analysis quando comparamos as células estromais mesenquimais isoladas de pacientes com esclerose múltipla às células controle. As cores verde e vermelha representam, respectivamente, repressão ou indução da expressão gênica nas células estromais mesenquimais (CTMs) dos pacientes com esclerose múltipla, em comparação às CTMs isoladas de doadores saudáveis. A intensidade é proporcional à razão (fold change) de expressão entre os sinais obtidos nos microarrays.

\subsubsection{CAPACIDADE DE INIBIÇÃO DA PROLIFERAÇÃO DE LINFÓCITOS ALOGÊNICOS}

Primeiramente, observamos o efeito inibitório de CTMs isoladas de doadores saudáveis de medula óssea sobre a proliferação de linfócitos alogênicos. Para tal, as células mononucleares (CMNs) foram isoladas, marcadas com CFSE, estimuladas ou não com PHA e cultivadas na presença de números decrescentes de CTMs, nas seguintes proporções: CTMs/CMNs $1 / 2 ; 1 / 5 ; 1 / 10 ; 1 / 20 ; 1 / 50$ e 1/100. A Figura 34 contém imagens obtidas por 
microscopia de contraste de fase de um experimento de cocultivo de CTMs isoladas de doadores saudáveis e linfócitos alogênicos.
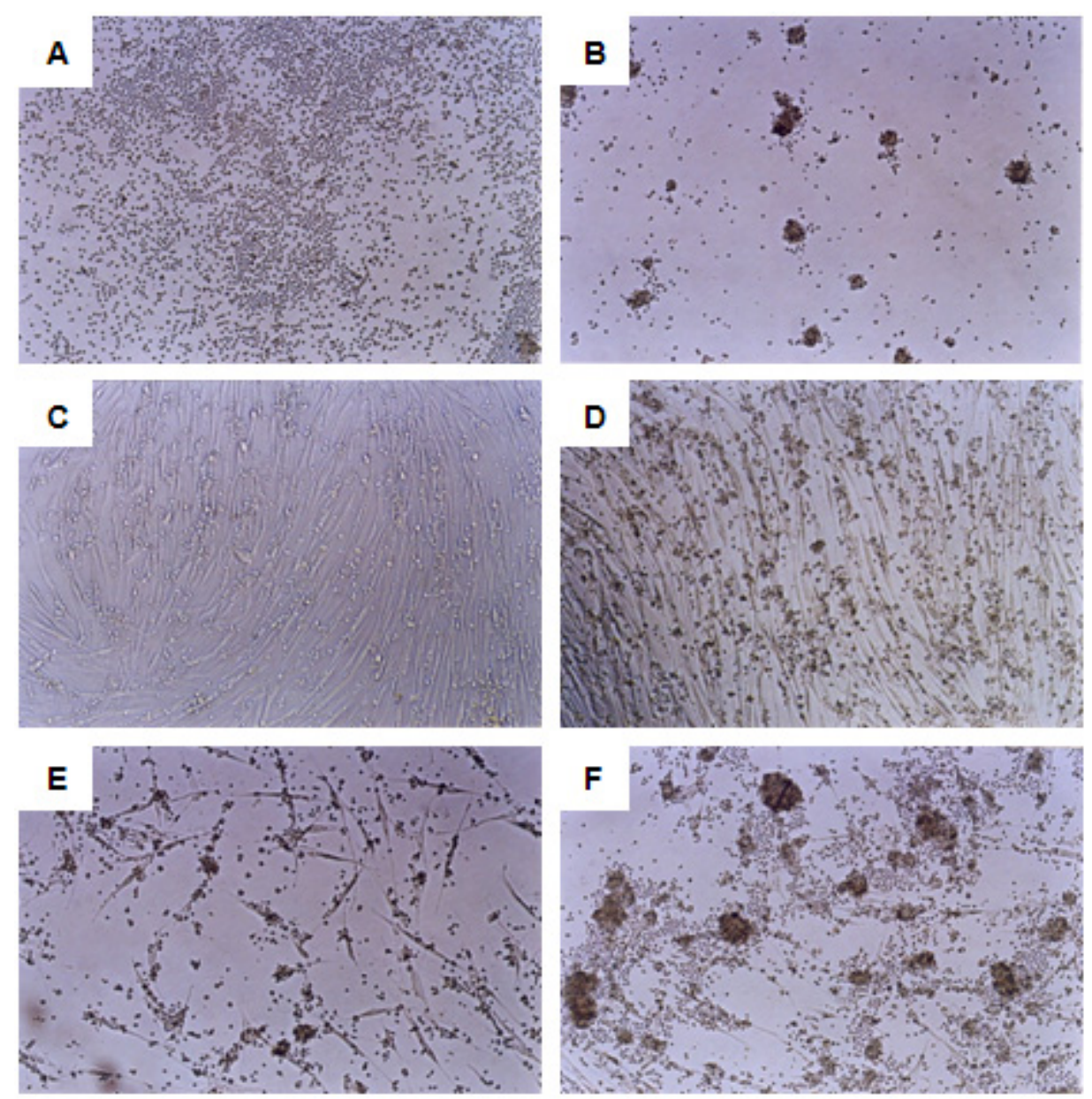

Figura 34: Efeito inibitório de células estromais mesenquimais isoladas de doadores saudáveis de medula óssea na proliferação de linfócitos alogênicos. A. Células mononucleares do sangue periférico (CMNs) de indivíduo saudável marcadas com CFSE (aumento 100x), B. CMNs de indivíduo saudável marcadas com CFSE e estimuladas com PHA (aumento 100x). C-F. CMNs de indivíduo saudável, marcadas com CFSE e estimuladas com PHA, na presença de números crescentes de CTMs isoladas de indivíduo saudável (aumento 100x). C. Proporção CTMs/CMNs 1/5. D. Proporção CTMs/CMNs 1/10. E. Proporção CTMs/CMNs 1/20. F. Proporção CTMs/CMNs 1/100.

O ensaio de cocultivo de CTMs de doadores saudáveis de medula óssea com CMNs alogênicas foi realizado em 16 amostras. A média e erro padrão da porcentagem de proliferação das CMNs estimuladas com PHA foi de 78,27 $\pm 2,35 \%$, porcentagem essa utilizada para indicar se ocorreu ou não inibição da proliferação das CMNs na presença de números decrescentes de CTMs de doadores saudáveis. As médias das porcentagens de proliferação verificadas nas diferentes razões entre CTMs/CMNs foram: i) $1 / 2=24,62 \pm$ $6,10 \%$; ii) $1 / 5=28,14 \pm 4,03 \%$; iii) $1 / 10=40,36 \pm 5,74 \%$; iv) $1 / 20=54,12 \pm 4,77 \%$; v) $1 / 50=$ $66,07 \pm 3,56 \%$ e, vi) $1 / 100=72,52 \pm 2,77 \%$. Foi encontrada diferença significante entre a média da porcentagem controle (CMNs + PHA) e as médias das CMNs cocultivadas com CTMs controles nas proporções 1/2, 1/5, 1/10 e 1/20 ( $P<0,0001)$ (Figura 35A). 
A porcentagem de inibição da proliferação foi calculada pela seguinte fórmula (\% proliferação $\mathrm{CMNs}+\mathrm{PHA}$ - \% proliferação CTMs/CMNs + PHA nas diferentes proporções) dividido pela \% proliferação CMNs + PHA x 100. As médias e erro padrão das porcentagens de inibição da proliferação de CMNs estimuladas com PHA na presença de números decrescentes de CTMs de indivíduos saudáveis foram de $69,37 \pm 7,25 \%$ na proporção de $1 / 2,64,81 \pm 4,45 \%$ na proporção de 1/5, 49,69 $\pm 6,20 \%$ na proporção 1/10, 31,42 $\pm 5,07 \%$ na razão $1 / 20,14,96 \pm 4,52 \%$ na razão $1 / 50$ e $6,64 \pm 3,62 \%$ na proporção de $1 / 100$. Foram observadas diferenças significantes $(P<0,0001)$ quando comparamos as porcentagens de inibição da proliferação nas proporções $1 / 2$ e 1/5 com as proporções 1/20, 1/50 e 1/100 (Figura 35B).

Os resultados relativos à porcentagem de proliferação e porcentagem de inibição da proliferação de CMNs alogênicas, em conjunto, indicam diminuição dose-dependente da proliferação dos linfócitos na presença de números crescentes de CTMs isoladas de doadores saudáveis.

A)

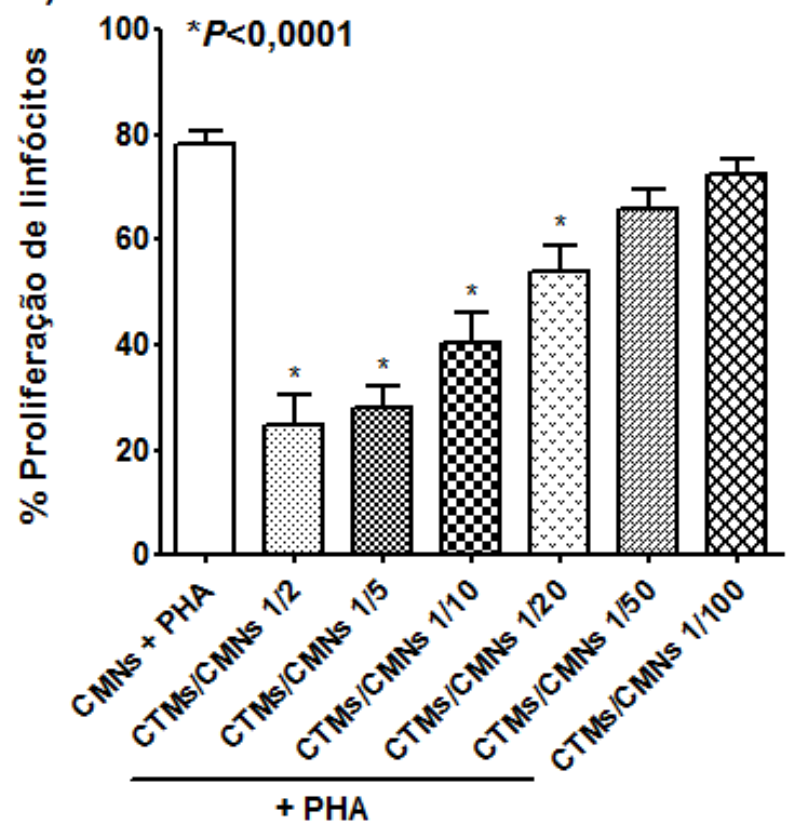

B)

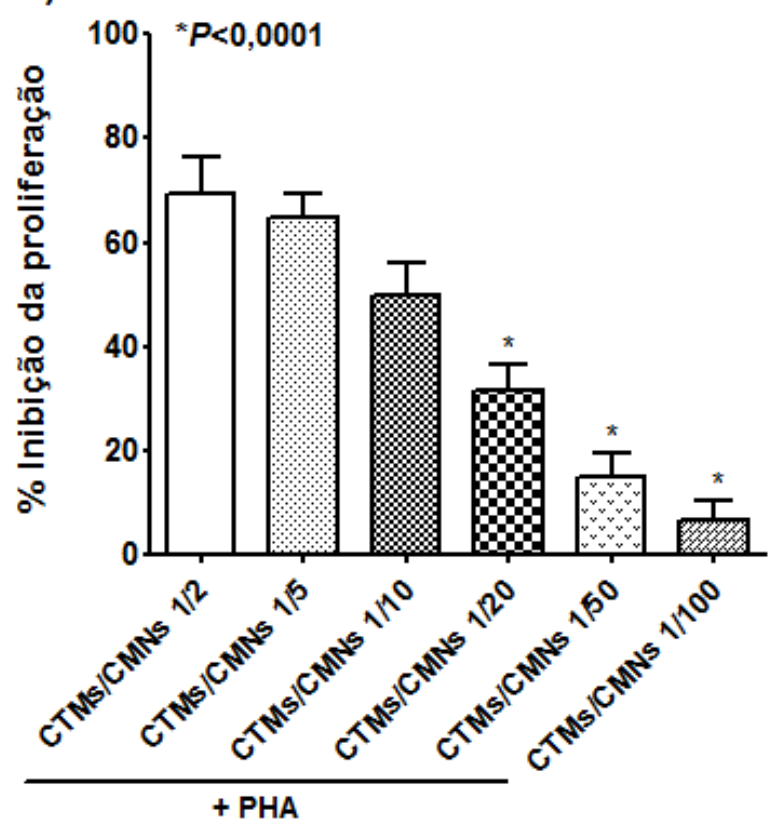

Figura 35: Porcentagens de proliferação e inibição da proliferação de linfócitos alogênicos cocultivados com células estromais mesenquimais isoladas de dezesseis doadores saudáveis de medula óssea. A) Porcentagens de proliferação e, B) Porcentagens de inibição da proliferação de linfócitos alogênicos cocultivados com células estromais mesenquimais (CTMs) de doadores saudáveis. A proliferação de linfócitos foi avaliada por citometria de fluxo, pelo método de diluição com CFSE e marcação com anti-CD3-PE. Células mononucleares (CMNs) foram isoladas de doadores saudáveis, marcadas com CFSE, estimuladas com PHA $(2,5 \mu \mathrm{g} / \mathrm{ml})$ e cultivadas na presença de números decrescentes de CTMs $(1 / 2,1 / 5,1 / 10,1 / 20,1 / 50$ e $1 / 100)$ por 5 dias a $37^{\circ} \mathrm{C}$. As amostras foram testadas em triplicatas e os dados foram analisados pelo teste de variância (one-way ANOVA) e pós-teste de Dunnett's e estão representados pelas médias e erro padrão dos resultados obtidos. Em A ${ }^{*} P<0,0001$, colunas comparadas a CMNs $+\mathrm{PHA}$ e B) ${ }^{*} P<0,0001$, colunas comparadas a CTMs/CMNs $1 / 2$ e $1 / 5$. 
O ensaio de inibição da proliferação de linfócitos alogênicos também foi realizado, utilizando-se dez amostras de CTMs isoladas da medula óssea de pacientes com EM do período pré-transplante. A média e erro padrão da porcentagem de proliferação das CMNs estimuladas com PHA foi de 71,32 $\pm 4,10 \%$. As médias das porcentagens de proliferação verificadas nas diferentes proporções CTMs/CMNs foram: i) $1 / 2=: 33,36 \pm 4,24 \%$; ii) $1 / 5=$ $39,09 \pm 6,93 \%$; iii) $1 / 10=46,64 \pm 6,37 \%$; iv) $1 / 20=51,09 \pm 4,69 \%$; v) $1 / 50=56,80 \pm 4,29 \%$; vi) $1 / 100=57,26 \pm 6,80 \%$. Foi encontrada diferença significante entre a média da porcentagem controle $(\mathrm{CMNs}+\mathrm{PHA})$ e as médias das CMNs cocultivadas com CTMs nas proporções 1/2, $1 / 5$ e 1/10 ( $P=0,0002)$ (Figura 36A).

As médias das porcentagens de inibição da proliferação de CMNs estimuladas com $\mathrm{PHA}$, na presença de números crescentes de CTMs de pacientes com EM do período prétransplante foram de $52,15 \pm 5,65 \%$ na proporção de $1 / 2,44,04 \pm 11,17 \%$ na proporção de $1 / 5,34,0 \pm 9,82 \%$ na proporção $1 / 10,27,57 \pm 7,15 \%$ na razão $1 / 20,19,55 \pm 5,61 \%$ na razão $1 / 50$ e $18,98 \pm 8,50 \%$ na proporção de $1 / 100$. Não foram observadas diferenças significantes entre as porcentagens de inibição da proliferação nas diferentes proporções CTMs/CMNs (Figura 36B).

Os resultados relativos à porcentagem de proliferação e porcentagem de inibição da proliferação de CMNs alogênicas, em conjunto, assim como para as CTMs controles, indicam diminuição dose-dependente da proliferação dos linfócitos na presença de números crescentes de CTMs isoladas de pacientes com EM. 

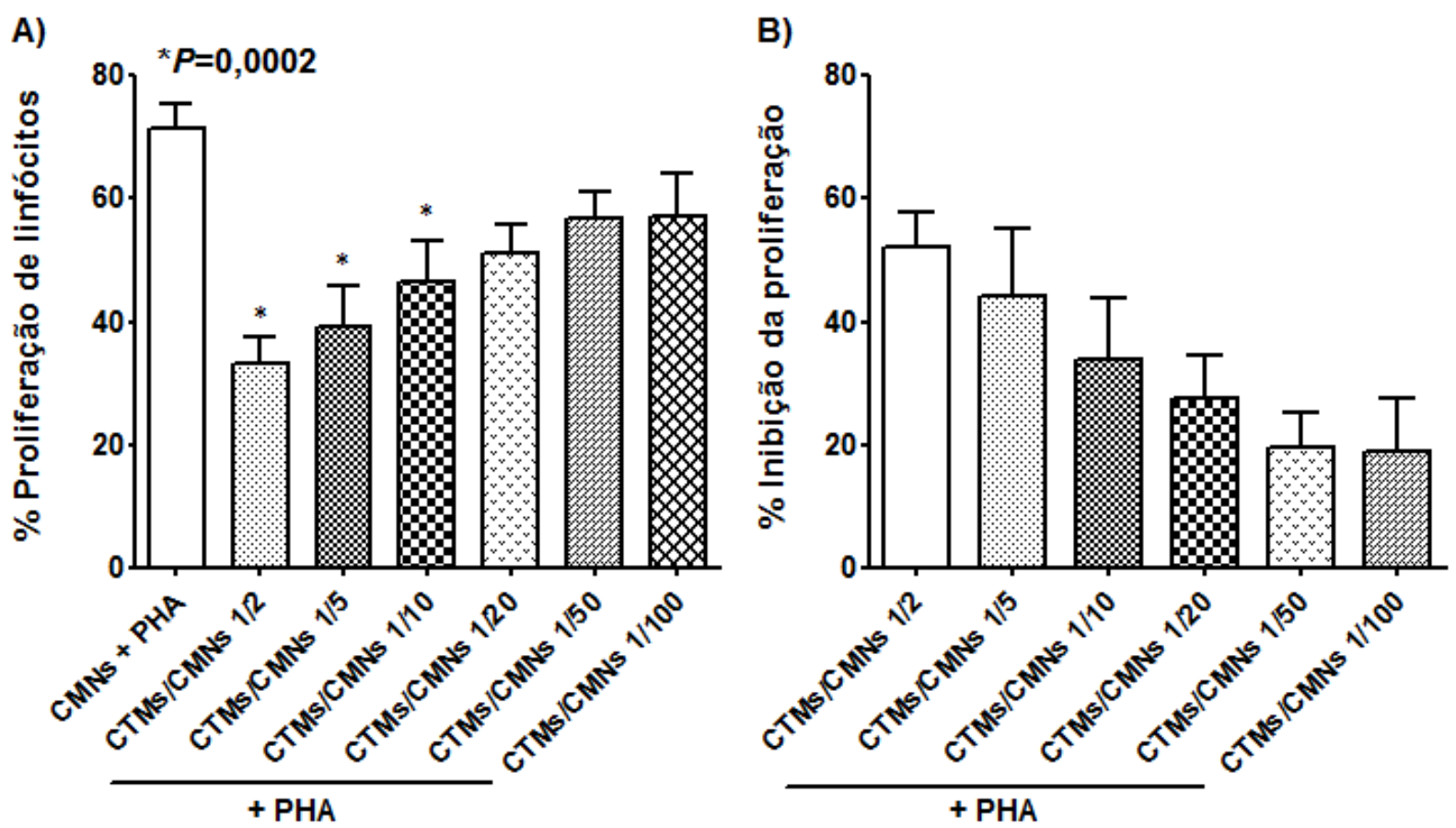

Figura 36: Porcentagens de proliferação e inibição da proliferação de linfócitos alogênicos cocultivados com células estromais mesenquimais isoladas da medula óssea de dez pacientes com esclerose múltipla do período pré-transplante. B) Porcentagens de inibição da proliferação de linfócitos alogênicos cocultivados com células estromais mesenquimais (CTMs) de pacientes com esclerose múltipla pré-transplante. A proliferação de linfócitos foi avaliada por citometria de fluxo, pelo método de diluição com CFSE e marcação com anti-CD3-PE. Células mononucleares (CMNs) foram isoladas de doadores saudáveis, marcadas com CFSE, estimuladas com PHA $(2,5 \mu \mathrm{g} / \mathrm{ml})$ e cultivadas na presença de números decrescentes de CTMs (1/2, 1/5, 1/10, 1/20, 1/50 e 1/100) por 5 dias a $37^{\circ} \mathrm{C}$. As amostras foram testadas em triplicatas e os dados foram analisados pelo teste de variância (one-way ANOVA) e pós-teste de Dunnett's e estão representados pelas médias e erro padrão dos resultados obtidos. Em A) $P=0,0002$, colunas comparadas a CMNs + PHA.

O ensaio de cocultivo de CMNs alogênicas com CTMs de pacientes com EM do período pós-TACTH foi realizado em nove amostras. A média e erro padrão da porcentagem de proliferação das CMNs estimuladas com PHA foi de $77,89 \pm 3,62 \%$. As médias e erro padrão das porcentagens de proliferação observadas nas diferentes proporções CTMs/CMNs foram: razão 1/2: $30,23 \pm 9,51 \%$; $1 / 5$ : 33,94 $\pm 4,05 \% ; 1 / 10: 55,38 \pm 8,74 \%$; 1/20: $64,34 \pm 9,18 \% ; 1 / 50: 68,87 \pm 7,72 \%$ e na proporção $1 / 100: 74,58 \pm 4,83 \%$. Foi encontrada diferença significante entre a média da porcentagem controle (CMNs + PHA) e as médias das CMNs cocultivadas com CTMs controles nas proporções 1/2 e 1/5 $(P<0,0001)$ (Figura 37A).

As porcentagens de inibição da proliferação de CMNs estimuladas com PHA na presença de números crescentes de CTMs de pacientes com EM no pós-transplante foram de $60,41 \pm 12,54 \%$ na proporção de $1 / 2,56,31 \pm 4,79 \%$ na proporção $1 / 5,28,32 \pm 11,18 \%$ na proporção $1 / 10,16,41 \pm 12,53 \%$ na proporção $1 / 20,10,38 \pm 11,07 \%$ na proporção $1 / 50$ e $2,98 \pm 7,86 \%$ na proporção de $1 / 100$. Foram observadas diferenças significantes $(P=0,0006)$ 
quando comparamos as porcentagens de inibição da proliferação nas proporções 1/2 e 1/5 com as proporções 1/50 e 1/100 (Figura 37B).

Os resultados relativos à porcentagem de proliferação e porcentagem de inibição da proliferação de CMNs alogênicas indicam diminuição dose-dependente da proliferação dos linfócitos na presença de números crescentes de CTMs isoladas de pacientes com EM do período pós-transplante.

A)

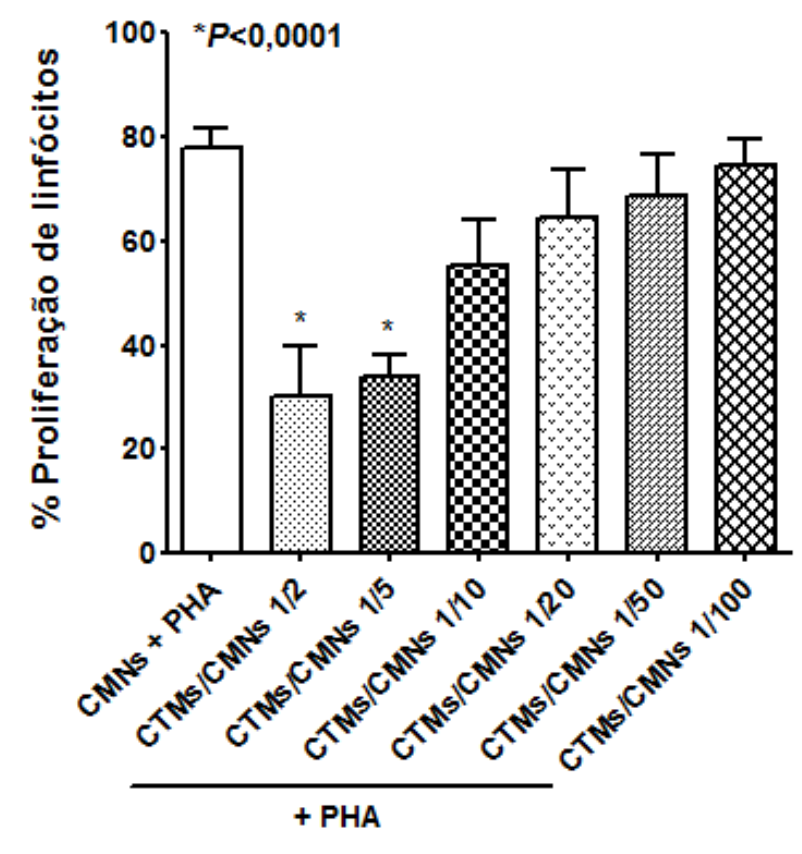

B)

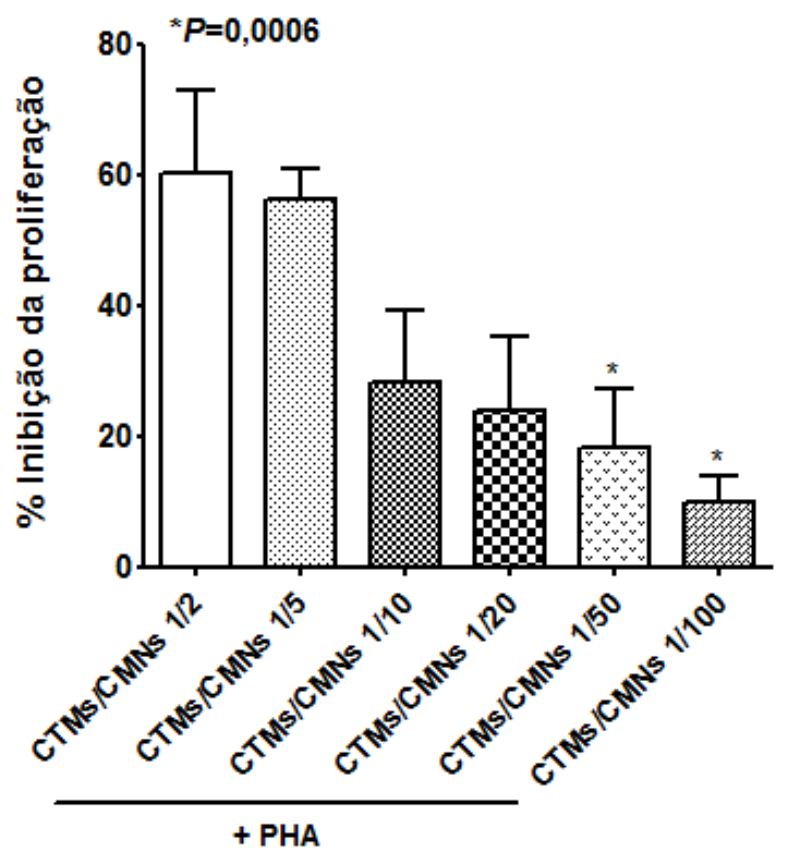

Figura 37: Porcentagens de proliferação e inibição da proliferação de linfócitos alogênicos cocultivados com células estromais mesenquimais isoladas da medula óssea de nove pacientes com esclerose múltipla no período pós-transplante. B) Porcentagens de inibição da proliferação de linfócitos alogênicos cocultivados com células estromais mesenquimais (CTMs) de pacientes com esclerose múltipla pós-transplante. A proliferação de linfócitos foi avaliada por citometria de fluxo, pelo método de diluição com CFSE e marcação com anti-CD3-PE. Células mononucleares (CMNs) foram isoladas de doadores saudáveis, marcadas com CFSE, estimuladas com PHA $(2,5 \mu \mathrm{g} / \mathrm{ml})$ e cultivadas na presença de números decrescentes de CTMs $(1 / 2,1 / 5,1 / 10$, $1 / 20,1 / 50$ e $1 / 100$ ) por 5 dias a $37^{\circ} \mathrm{C}$. As amostras foram testadas em triplicatas e os dados foram analisados pelo teste de variância (one-way ANOVA) e pós-teste de Dunnett's e estão representados pelas médias e erro padrão dos resultados obtidos. Em $A)^{*} P<0,0001$, colunas comparadas a CMNs + $\mathrm{PHA}$ e B) ${ }^{*} P=0,0006$, colunas comparadas a CTMs/CMNs $1 / 2$ e $1 / 5$.

Quando comparamos a capacidade antiproliferativa das CTMs isoladas de doadores saudáveis com a de pacientes com EM do período pré-transplante, observamos diferenças significantes tanto na porcentagem de proliferação (média \pm erro padrão controles: $24,62 \pm 6,10 \%$; pacientes $33,36 \pm 4,24 ; P=0,024)$, quanto na porcentagem de inibição da proliferação de linfócitos (média \pm erro padrão controles: $69,37 \pm 7,25 \%$; pacientes $52,15 \pm 5,65 \% ; P=0,024$ ) na proporção $1 / 2$. A capacidade antiproliferativa das CTMs controles ( 70\% de inibição) foi significativamente maior na proporção $1 / 2$ quando 
comparada a das CTMs isoladas de pacientes com EM ( 50\% de inibição) (Figuras 38 e 39).

Na proporção CTMs/CMNs 1/100, a porcentagem de proliferação encontrada nos experimentos com CTMs de pacientes pré-transplante foi significativamente menor quando comparada à observada nos controles (média \pm erro padrão controles: $72,52 \pm 2,77 \%$; pacientes $57,26 \pm 6,80 \% ; P=0,034$ ) (Figura 38 ).

Quando comparamos as porcentagens de proliferação dos linfócitos nos experimentos com CTMs isoladas dos pacientes nos períodos pré- e pós-transplante, não observamos diferenças significantes nas diferentes proporções CTMs/CMNs.

Não observamos correlação das porcentagens de proliferação e porcentagens de inibição da proliferação de linfócitos alogênicos nas diferentes proporções com os valores de EDSS dos pacientes com EM nos períodos pré- e pós-TACTH.

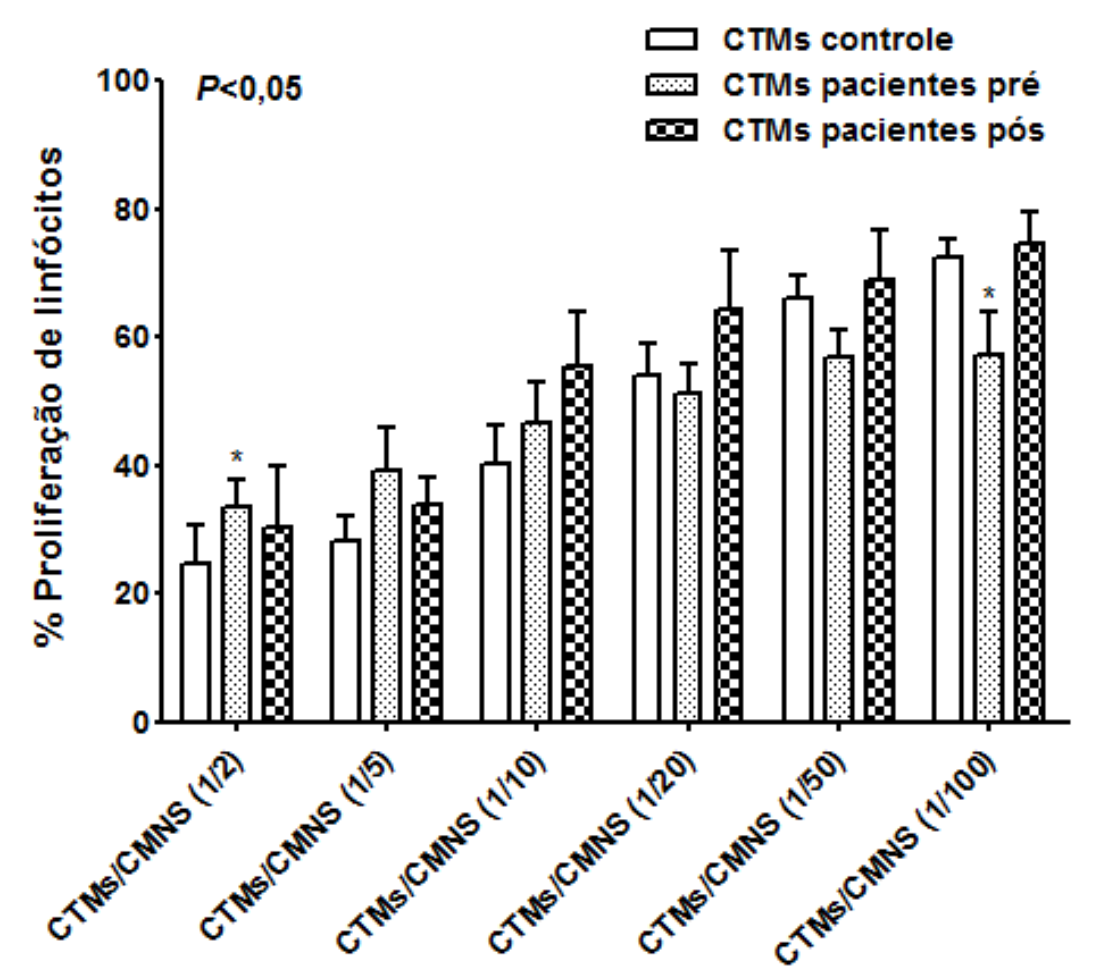

Figura 38: Comparação do efeito antiproliferativo de células estromais mesenquimais isoladas de doadores saudáveis e de pacientes com esclerose múltipla nos períodos pré- e póstransplante. Porcentagens de proliferação de células mononucleares (CMNs) marcadas com CFSE, estimuladas com PHA na presença de números decrescentes de células estromais mesenquimais (CTMs) (proporções CTMs/CMNs 1/2, 1/5, 1/10, 1/20, 1/50, 1/100). As amostras foram testadas em triplicatas e os dados foram analisados pelo teste de variância (one-way ANOVA) e pós-teste de Dunnett's e estão representados pelas médias e erro padrão dos resultados obtidos. ${ }^{*} P<0,05$ comparada à coluna CTMs controle. 


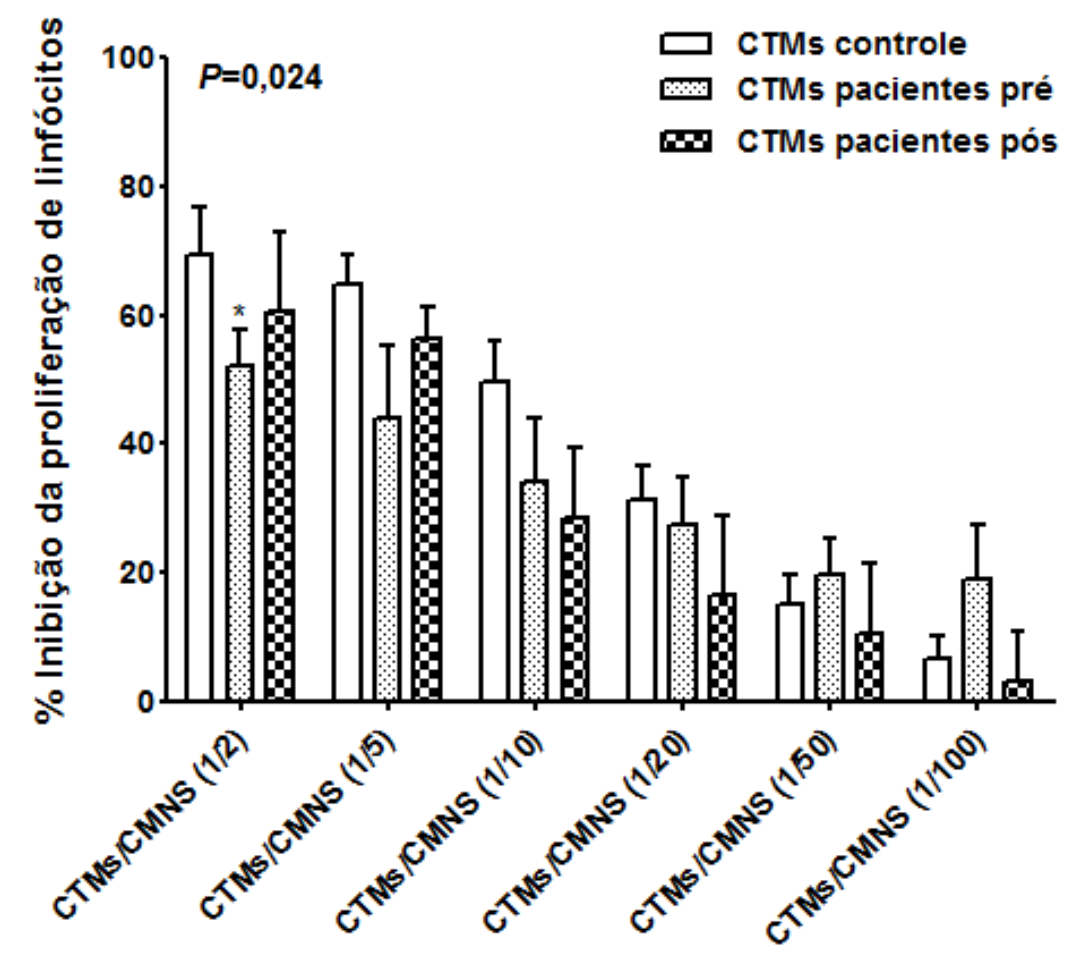

Figura 39: Comparação da capacidade de inibição da proliferação de linfócitos alogênicos após cocultivo com células estromais mesenquimais isoladas de doadores saudáveis e de pacientes com esclerose múltipla dos períodos pré-e pós-transplante. Porcentagens de inibição da proliferação de células mononucleares (CMNs) marcadas com CFSE, estimuladas com PHA na presença de números decrescentes de células estromais mesenquimais (CTMs)(proporções CTMs/CMNs 1/2, 1/5, 1/10,1/20,1/50,1/100). As amostras foram testadas em triplicatas e os dados foram analisados pelo teste de variância (one-way ANOVA) e pós-teste de Dunnett's e estão representados pelas médias e erro padrão dos resultados obtidos. ${ }^{*} P=0,024$ comparada à coluna CTMs controle.

\subsubsection{AVALIAÇÃO DAS SUBPOPULAÇÕES LINFOCITÁRIAS APÓS O COCULTIVO COM CÉLULAS ESTROMAIS MESENQUIMAIS}

Os experimentos de imunorregulação consistiram no cocultivo de CTMs isoladas de doadores saudáveis de medula óssea e de pacientes (pré- e pós-TACTH) com células mononucleares (CMNs) alogênicas, estimulados com PHA, comparando aos controles contendo CMNs estimuladas com PHA. Nesses ensaios, avaliamos o fenótipo e frequência de subpopulações linfocitárias (células $\mathrm{T} \mathrm{CD}^{+} \mathrm{CD}^{+}, \mathrm{CD}^{+} \mathrm{CD} 8^{+}, \mathrm{CD}^{+} \mathrm{NKT}, \mathrm{CD} 4^{+} \mathrm{CD} 25^{\mathrm{hi}}$, $\mathrm{CD}^{+}{ }^{+} \mathrm{CD} 25^{\mathrm{hi}} \mathrm{FOXP}^{+}, \mathrm{CD} 4^{+} \mathrm{CD} 25^{\mathrm{hi}_{\mathrm{G}}} \mathrm{GIR}^{+}, \mathrm{CD}^{+} \mathrm{CD} 25^{\mathrm{hi}} \mathrm{CTLA}^{+} 4^{+}, \mathrm{CD} 8^{+} \mathrm{CD} 28^{-}, \mathrm{CD} 8^{+} \mathrm{CD} 28^{-}$ $\mathrm{FOXP}^{+}, \mathrm{CD}^{+} \mathrm{CD}^{+} \mathrm{HLA}^{-\mathrm{G}^{+}}$e $\left.\mathrm{CD} 3^{+} \mathrm{CD} 8^{+} \mathrm{HLA}-\mathrm{G}^{+}\right)$, recuperadas após os ensaios de cocultivo.

A frequência de linfócitos $\mathrm{T} \mathrm{CD3}^{+} \mathrm{CD} 4^{+}$e $\mathrm{T} \mathrm{CD}^{+}{ }^{+} \mathrm{CD} 8^{+}$recuperada após o cocultivo de células mononucleares com CTMs controle e de pacientes com EM pré- e póstransplante foi semelhante à obtida para os controles (CMNs + PHA) (Tabela 5).

Com o intuito de avaliar o potencial das CTMs isoladas de doadores saudáveis e pacientes com EM de induzir a formação de células NKT reguladoras, avaliamos a 
frequência destas células recuperadas após cinco dias de cocultivo com as CTMs. Não foram observadas diferenças significantes entre as frequências de células $\mathrm{CD}^{+} \mathrm{NKT}^{+}$ recuperadas dos cocultivos com CTMs de pacientes pré- e pós-transplante, quando comparadas aos cocultivos com CTMs controles e CMNs + PHA (Tabela 5).

Com relação à frequência de células $\mathrm{T} \mathrm{CD} 4^{+} C D 25^{\mathrm{hi}}$, recuperadas após os cocultivos, não observamos diferenças significantes entre os grupos com CTMs controle e de pacientes pré- e pós-TACTH e CMNs + PHA. Além disso, a frequência de células $\mathrm{T}$ reguladoras, $\mathrm{CD} 4^{+} \mathrm{CD} 25^{\mathrm{hi}} \mathrm{FOXP}^{+}, \mathrm{CD} 4^{+} \mathrm{CD} 25^{\mathrm{hi}} \mathrm{CTLA}-4^{+}$e $\mathrm{CD} 4^{+} \mathrm{CD} 25^{\mathrm{hi}} \mathrm{GITR}^{+}$, obtidas após o cocultivo com CTMs controle e de pacientes pré- e pós-TACTH foi semelhante aos controles CMNs + PHA (Tabela 5).

Não foram encontradas diferenças significantes na frequência de células $T$ $\mathrm{CD}^{+}{ }^{+} \mathrm{CD} 28^{-}$e $\mathrm{CD}^{+}{ }^{+} \mathrm{CD} 28^{-} \mathrm{FOXP3}^{+}$entre os cocultivos com CTMs controle e de pacientes pré- e pós-transplante aos controles CMNs + PHA (Tabela 5).

Quando avaliamos a frequência de linfócitos $T C D 3^{+} C D 4^{+}$e $C D 3^{+} C D 8^{+}$expressando HLA-G após o cocultivo com CTMs controle e de pacientes pré- e pós-TACTH, não verificamos diferenças estatisticamente significantes entre estas frequências em relação aos controles CMNs + PHA (Tabela 5).

Tabela 5: Porcentagens de subpopulações linfocitárias recuperadas após o cocultivo de linfócitos alogênicos e células estromais mesenquimais isoladas de doadores saudáveis (controles) e de pacientes pré- e pós-transplante.

\begin{tabular}{|c|c|c|c|c|}
\hline $\begin{array}{c}\text { Subpopulações } \\
\text { linfocitárias }\end{array}$ & $\begin{array}{c}\text { CMNs + PHA } \\
\text { controles }\end{array}$ & $\begin{array}{l}\text { CTMs } \\
\text { Controle }\end{array}$ & $\begin{array}{c}\text { CTMs } \\
\text { pacientes pré }\end{array}$ & $\begin{array}{c}\text { CTMs } \\
\text { pacientes pós }\end{array}$ \\
\hline 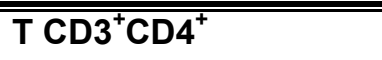 & $35,20 \pm 2,29 \%$ & $29,82 \pm 5,19 \%$ & $32,87 \pm 4,25 \%$ & $32,20 \pm 3,72 \%$ \\
\hline $\mathrm{T} \mathrm{CD}^{+} \mathrm{CD}^{+}$ & $67,18 \pm 3,63 \%$ & $47,26 \pm 7,90 \%$ & $52,71 \pm 6,51 \%$ & $56,62 \pm 5,91 \%$ \\
\hline $\mathrm{TCD}^{+} \mathrm{NKT}$ & $3,16 \pm 1,00 \%$ & $4,36 \pm 1,89 \%$ & $2,73 \pm 0,48 \%$ & $2,98 \pm 1,34 \%$ \\
\hline $\mathrm{T} \mathrm{CD}^{+}{ }^{+} \mathrm{CD} 25^{\mathrm{hi}}$ & $31,20 \pm 4,63 \%$ & $18,16 \pm 5,85 \%$ & $18,28 \pm 3,65 \%$ & $28,92 \pm 8,31 \%$ \\
\hline $\mathrm{T} \mathrm{CD}^{+}$CD25 ${ }^{\mathrm{hi}} \mathrm{FOXP}^{+}$ & $2,28 \pm 0,75 \%$ & $0,59 \pm 0,25 \%$ & $2,57 \pm 0,98 \%$ & $1,42 \pm 0,58 \%$ \\
\hline $\mathrm{T} \mathrm{CD}^{+}{ }^{+} \mathrm{CD} 25^{\mathrm{hi}} \mathrm{CTLA}-4^{+}$ & $4,09 \pm 0,83 \%$ & $2,50 \pm 0,66 \%$ & $3,48 \pm 1,56 \%$ & $3,35 \pm 1,78 \%$ \\
\hline $\mathrm{T} \mathrm{CD}^{+}{ }^{+} \mathrm{CD} 25^{\mathrm{hi}} \mathrm{GITR}^{+}$ & $12,80 \pm 2,40 \%$ & $9,35 \pm 2,73 \%$ & $13,9 \pm 3,70 \%$ & $17,1 \pm 5,75 \%$ \\
\hline $\mathrm{T} \mathrm{CD8}^{+} \mathrm{CD} 28^{-}$ & $43,46 \pm 6,84 \%$ & $43,39 \pm 10,05 \%$ & $67,19 \pm 20,49 \%$ & $26,29 \pm 7,89 \%$ \\
\hline $\mathrm{T} \mathrm{CD8}^{+} \mathrm{CD}^{-} 8^{-} \mathrm{FOXP3}^{+}$ & $0,01 \pm 0,008 \%$ & $0,39 \pm 0,37 \%$ & $1,78 \pm 1,70 \%$ & $0,11 \pm 0,06 \%$ \\
\hline T CD4 $^{+}{ }^{H L A}-G^{+}$ & $2,13 \pm 0,35 \%$ & $3,71 \pm 1,79 \%$ & $2,88 \pm 0,70 \%$ & $2,92 \pm 1,30 \%$ \\
\hline T CD8 $^{+}$HLA-G ${ }^{+}$ & $2,62 \pm 0,51 \%$ & $2,42 \pm 0,74 \%$ & $2,03 \pm 0,48 \%$ & $1,50 \pm 0,41 \%$ \\
\hline
\end{tabular}

Os dados foram analisados pelo teste de variância (One-way ANOVA) e múltiplas comparações (teste de Dunett's) e estão representados pelas médias e erro padrão dos resultados obtidos. 


\subsubsection{PERFIL DE CITOCINAS NO SOBRENADANTE DAS COCULTURAS}

Nos ensaios de cocultivo, além dos experimentos de inibição da proliferação de linfócitos alogênicos e ensaios de imunorregulação para avaliar a capacidade das CTMs de induzir subpopulações reguladoras, foram realizados experimentos para quantificar citocinas no sobrenadante das colculturas de CTMs isoladas de controles saudáveis e de pacientes pré- e pós-transplante para avaliar diferenças na liberação de fatores solúveis por estas células.

Com relação à quantificação de citocinas pró-inflamatórias nas nossas coculturas de CTMs e linfócitos alogênicos, não observamos diferenças significantes na concentração de IFN- $\gamma$, TNF, IL-1 $\beta$ e IL-6 quando testamos os sobrenadantes das coculturas com CTMs controles e de pacientes pré- e pós-TACTH (Figura 40).

A concentração das citocinas anti-inflamatórias IL-10 $(P=0,016)$ e TGF- $\beta$ $(P=0,0002)$ no sobrenadante das coculturas com CTMs de pacientes pré- (IL-10: $53,8 \pm 13,7$ $\mathrm{pg} / \mathrm{mL}$; TGF- $\beta$ : $59,4 \pm 6,8 \mathrm{pg} / \mathrm{mL})$ e pós-transplante $(54,5 \pm 13,8 \mathrm{pg} / \mathrm{mL}$; TGF- $\beta$ : $122,0 \pm 14,8$ $\mathrm{pg} / \mathrm{mL}$ ) estava significativamente reduzida em relação às coculturas com CTMs controle (126,2 $\pm 32,17$ pg/mL; TGF- $\beta$ : 226,6 $\pm 28,9$ pg/mL) (Figura 40).

Não foram observadas diferenças significantes nos valores de concentração de HGF e da quimiocina CXCL-10 (IP-10) nas coculturas com CTMs controle e de pacientes pré- e pós-transplante (Figura 40). 

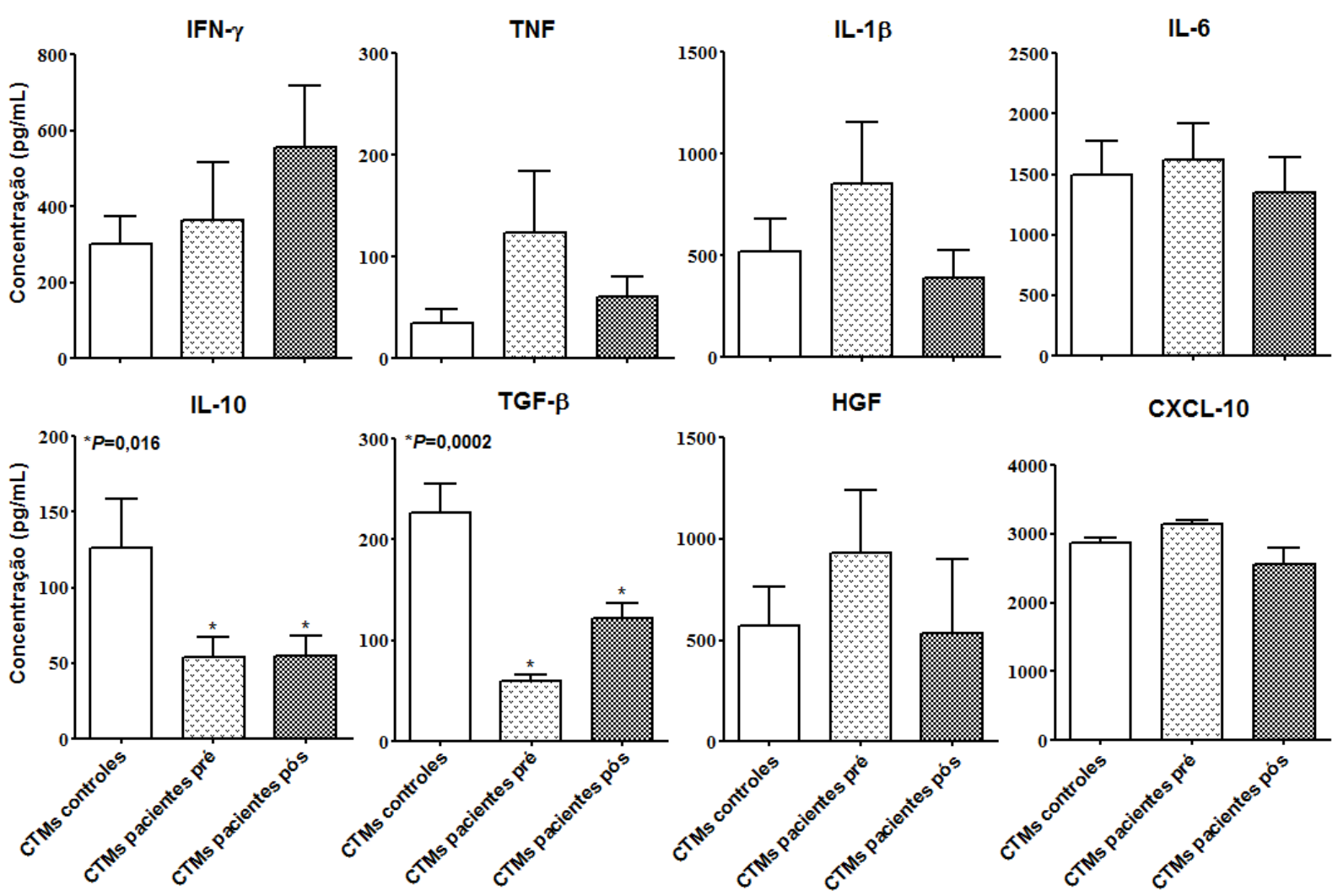

Figura 40: Concentração de citocinas pró- e anti-inflamatórias, HGF e da quimiocina CXCL-10 no sobrenadante das coculturas de linfócitos alogênicos com células estromais mesenquimais isoladas de doadores saudáveis e de pacientes com esclerose múltipla pré- e pós-transplante. As amostras foram testadas em triplicatas e os dados foram analisados pelo teste de Kruskal-Wallis e pós-teste de Dunn. As amostras foram testadas em triplicatas e os dados estão representados pela média e erro padrão. *Somente foram observadas diferenças significantes na concetração de IL-10 $(P=0,016)$ e TGF $-\beta(P=0,0002)$. 
DISCUSSÃO 


\section{DISCUSSÃO}

\subsection{ANÁLISE DA EXPRESSÃO GÊNICA NAS CÉLULAS-TRONCO HEMATOPOÉTICAS}

A terapia celular utilizando intensa imunossupressão seguida do transplante autólogo de células-tronco hematopoéticas (TACTH) vem sendo utilizada como importante estratégia terapêutica em doenças autoimunes (DAls), como EM (BURT et al., 2012; MANCARDI et al., 2012; SACCARDI et al., 2012; SHEVCHENKO et al. 2012). A base racional desse tipo de intervenção é que o condicionamento linfo/mieloablativo possa eliminar as células autorreativas e, a partir de então, as CTHs precursoras transplantadas possam dar origem a novo e tolerante sistema imune, baseando-se na hipótese de que as DAls sejam consequência da perda da tolerância periférica (FARIAS, 2006; GOSSELIN \& RIVEST, 2011).

As DAls se desenvolvem em indivíduos predispostos geneticamente, usualmente, em associação com fatores ambientais, como infecções, propiciando desregulação do sistema imune (MAAS et al., 2002; MACKAY et al., 2008; COSTENBADER et al., 2012). No entanto, ainda não se sabe se essas doenças se desenvolvem a partir da quebra da tolerância periférica ou se as alterações nas células do sistema imune são provenientes de alterações intrínsecas da célula-tronco hematopoética desses pacientes.

Alguns trabalhos em modelos animais de autoimunidade sugerem que as DAls sejam desencadeadas por defeitos nas células-tronco precursoras da medula óssea (IKEHARA et al., 1990; IKEHARA, 1998; IKEHARA, 2003; IKEHARA, 2008). Existem evidências na literatura de transferência de DAls (doença celíaca e DM-1) por meio do transplante de medula óssea, o que sugere uma contribuição das CTHs no desenvolvimento das DAls. Além disso, trabalhos mostraram que pacientes com lúpus eritematoso sistêmico ou com artrite reumatóide apresentam reserva alterada de CTHs (em número e função) e função defeituosa de células estromais (PAPADAKI et al., 2002). Porém, esses trabalhos não mostraram se essas alterações são intrínsecas das células-tronco e poderiam ter papel importante no desenvolvimento dessas DAls ou se são determinadas pelo processo inflamatório causado pela doença no microambiente medular.

Com base em trabalhos que sugerem que as DAls sejam provenientes de defeitos intrínsecos nas células-tronco precursoras da medula óssea, o objetivo do nosso trabalho foi comparar o perfil de expressão gênica diferencial de CTHs isoladas da medula óssea de pacientes com EM com o de doadores saudáveis.

Em indivíduos saudáveis, Georgantas e colaboradores (2004) analisaram os perfis de expressão gênica de CTHs isoladas da medula óssea, de sangue de cordão umbilical e de sangue periférico, identificando 4.746 transcritos diferencialmente expressos nessas 
células. Esses transcritos codificavam fatores de transcrição, receptores, moléculas sinalizadoras, que desempenham papéis essenciais na sobrevivência celular, autorrenovação, diferenciação, migração e adesão das CTHs humanas. Diversos transcritos diferencialmente expressos estavam envolvidos no processo de hematopoese, como KIT, FLT3, GATA2, GATA3, P27, HOXA5 e HOXA9. No entanto, os autores reconhecem que, embora essas células sejam capazes de reconstituir a hematopoese em ensaios in vivo, elas compõem populações heterogêneas, podendo conter células progenitoras em diferenciação. Outra consideração relevante discutida pelos autores é a dificuldade de isolamento de células humanas $\mathrm{CD} 34^{+}$, altamente puras, suficientes para gerar quantidades de RNA necessárias para os experimentos de hibridação. Esse tipo de dificuldade também foi encontrada em nosso trabalho.

Em doenças hematológicas, Diaz-Blanco e colaboradores (2007) compararam o perfil de expressão gênica diferencial, obtido por microarrays, de células CD $34^{+}$isoladas da medula óssea de pacientes com leucemia mieloide crônica (LMC) com o de indivíduos saudáveis. As células CD34 dos pacientes com LMC apresentaram alterações nas vias de sinalização MAPK e PI3K/AKT, indução de genes envolvidos com a via do TGF- $\beta$, inibidores de metaloproteinases, além da ativação de genes associados com manutenção das CTHs e leucemogênese, como HOXA9 e MEIS1. De maneira semelhante, Gueller e colaboradores (2010) encotraram genes diferencialmente expressos nas CD34 de pacientes com síndrome mielodisplásica. Esses transcritos estavam relacionados com alterações no programa transcricional de diferenciação da linhagem mieloide, sugerindo que as CTHs desses pacientes tenham defeitos moleculares intrínsecos que culminam em proliferação e diferenciação anormal de progenitores hematopoéticos.

Com relação às DAls, o trabalho de Lutterotti e colaboradores (2012) avaliou o perfil de expressão gênica diferencial de CTHs mobilizadas para o sangue periférico de pacientes com EM e indivíduos saudáveis e não encontrou diferenças significantes entre essas células, sugerindo que elas não possuem perfil pró-inflamatório, suportando o uso do transplante autólogo dessas células em pacientes com EM. No entanto, nesse trabalho foram utilizadas CTHs purificadas após a mobilização para o sangue periférico com administração de G-CSF e ciclofosfamida, que promovem alterações no microambiente medular e, consequentemente, alterações na expressão gênica dessas células (LUTTEROTTI et al., 2012). Além disso, os autores utilizaram porcentagens de pureza das células $\mathrm{CD} 4^{+}$muito variáveis $(73,5-89,7 \%)$ que comprometem a confiabilidade dos dados de microarrays (LUTTEROTTI et al., 2012). Não existem dados na literatura sobre o perfil de expressão gênica diferencial de CTHs isoladas diretamente da medula óssea de pacientes com EM. 
Em nosso trabalho, as células $\mathrm{CD}^{+} 4^{+}$foram purificadas diretamente da medula óssea e encontramos 2.722 genes diferencialmente expressos $(P<0,01 ; \mathrm{FC} \geq 2,0)$ nas $\mathrm{CTHs}$ dos pacientes com EM em relação às células de doadores saudáveis. Esses genes estavam envolvidos em processos biológicos e vias de sinalização importantes na manutenção dessas células-tronco e em vias de sinalização relacionadas com diferenciação linfoide ou mieloide. Esses achados sugerem que as CTHs de pacientes com EM possuem alterações intrínsecas que podem estar relacionadas com o desencadeamento e patogênese da autoimunidade. Dentre as vias de sinalização alteradas, encontramos a sinalização da apoptose, sinalização Wnt, Notch, mTOR, PI3K/AKT e Ca/NFAT, que serão discutidas separadamente.

\section{- Sinalização da apoptose}

Nos últimos anos, vários trabalhos relataram o envolvimento da desregulação da expressão de moléculas da maquinaria apoptótica na patogênese das DAls (KAWAKAMI \& EGUCHI, 2002; KUHTREIBER et al., 2003; TODARO, 2004; HUGHES et al., 2006; OPFERMAN, 2008). É provável que alterações na expressão de genes da sinalização da apoptose, durante os mecanismos de tolerância central e periférica, possam estar envolvidos no escape de células autorreativas e desencadeamento de DAls (VAUX \& FLAVELL, 2000; OPFERMAN \& KORSMEYER, 2003; RIOUX \& ABBAS, 2005). Alguns trabalhos evidenciaram a participação das alterações de algumas vias da apoptose celular no desenvolvimento de DAls órgão-específicas, tais como o diabetes tipo 1 (HAYASHI \& FAUSTMAN, 2001; GRONSKI \& WEINEM, 2006) e EM (SHARIEF \& SEMRA, 2001; SHARIEF et al., 2002; SHARIEF et al., 2003; HEBB et al., 2008), e ainda, em DAls sistêmicas, como artrite reumatóide (POPE, 2002; LIU \& POPE, 2003; LIU et al., 2007) e lúpus eritematoso sistêmico (LIPHAUS et al., 2006; MUNOZ et al., 2007).

A apoptose pode ser iniciada pelas vias intrínseca ou mitocondrial e extrínseca ou via receptores de morte. Quando esses processos são desencadeados, um conjunto de proteases, as caspases, são ativadas para executar o programa final de morte celular programada, clivando substratos específicos, normalmente envolvidos na estrutura e integridade celulares (BRÖKER et al., 2005; GUSTAFSSON \& GOTTLIEB, 2007; OPFERMAN, 2008).

A via intrínseca é desencadeada pela ação de diferentes sinais de estresse intracelular, tais como irradiação, agentes quimioterápicos, vírus, bactérias e ausência de fatores de crescimento, os quais convergem para a mitocôndria. A ativação dessa via depende da liberação de citocromo $c$ e Smac/DIABLO para o citosol, que juntamente com a molécula APAF-1 e pró-caspase-9 formam o apoptossomo, que desencadeia a cascata de 
ativação das caspases efetoras 3, 6 e 7, que por sua vez, conduzem aos processos terminais de apoptose (OPFERMAN, 2008). A liberação de Smac/DIABLO pela mitocôndria auxilia na supressão de inibidores das caspases, como as IAP ou proteínas inibidoras da apoptose (clAP-1, clAP-2, Survivina, XIAP), que previnem a ativação das caspases bloqueando sua clivagem (OPFERMAN \& KORSMEYER, 2003; GUSTAFSSON \& GOTTLIEB, 2007). Algumas moléculas que atuam na mitocôndria são centrais no controle da apoptose, incluindo as proteínas da família Bcl-2. Essa família está dividida em membros que inibem a apoptose ou antiapoptóticos (Bfl-1, Bcl-2, Bcl- $\mathrm{x}_{\mathrm{L}}$, Bcl-w e Mcl-1) e membros pró-apoptóticos (Bad, Bak, Bax, Bid, Bok, Bimel, Bik, Noxa e Puma) (BORNER, 2003; HUGHES et al., 2006).

A via extrínseca é ativada pela interação de receptores localizados na superfície celular, denominados receptores de morte, aos seus ligantes específicos. Esses receptores incluem o Fas (CD95), TNFR1, DR3, DR4, DR5 e DR6. Essa via inicia-se pela trimerização dos DR, que no caso da interação Fas-FasL, permite o recrutamento de duas proteínas sinalizadoras, FADD (Fas-associated death domain) e pró-caspase-8, formando o complexo DISC (Death-inducing signaling complex). A pró-caspase-8 ativada pelo DISC é liberada para o citoplasma, aonde poderá agir na fase efetora do processo ao ativar diretamente a caspase-3. Alternativamente, a caspase-8 pode promover o desencadeamento da via intrínseca por meio da clivagem da molécula Bid, a qual se dirige à mitocôndria, induzindo a liberação de citocromo $c$ e Smac (OPFERMAN \& KORSMEYER, 2003; BOUILLET et al., 2009).

Os sinais de transdução mediados por FADD desempenham papel relevante na regulação da apoptose e proliferação celular. Durante a sinalização via receptores de morte, o FADD é essencial para o recrutamento e ativação da caspase 8. Na medula óssea, a diminuição da expressão ou ausência de FADD produz considerável redução do número de CTHs. Além disso, células progenitoras da medula óssea deficientes em FADD são defeituosas na habilidade de gerar células linfoides, mieloides e eritroides. Embora o FADD seja dispensável em estádios de comprometimento celulares mais tardios, como na linfopoese, essa molécula desempenha papel crítico nos estágios iniciais da hematopoese na medula óssea (ROSENBERG et al., 2011). Em nosso trabalho, encontramos repressão significante da expressão de $F A D D$, além da indução das caspases CASP8, CASP3, $C A S P 7$, sugerindo alterações na expressão de moléculas envolvidas na via extrínseca da apoptose nas CTHs de pacientes com EM. Além das vias extrínsecas e intrínsecas da apoptose, observamos alterações da expressão em genes que codificam proteínas da família das proteínas inibidoras da apoptose (IAPs), como a indução de XIAP e BIRC6 e repressão de DIABLO, nas CTHs de pacientes com EM. 
Com relação à via intrínseca da apoptose, a molécula Bid está envolvida na manutenção da quiescência e sobrevivência das CTHs. A diminuição da expressão e fosforilação de Bid resulta na exaustão do pool de CTHs e redução drástica na repopulação das CTHs in vivo (MARYANOVICH et al., 2012). Em nosso trabalho, encontramos repressão significante da expressão de genes pró-apoptóticos $B A K 1, B I D, B A D, B A X$ e dos antiapoptóticos $B C L 2 A 1$ ou $B F L-1, B C L 2 L 10, B C L 2 L 1$ ou $B C L-X L$, sugerindo alterações na expressão de várias moléculas envolvidas na via íntrinseca da apoptose nas CTHs de pacientes com EM.

Cocluindo, observamos desregulação da expressão de diversos genes relacionados ao processo de apoptose e, as alterações de expressão desses genes aparecem em todas as análises in silico realizadas (DAVID, GSEA e INGENUITY), sugerindo defeitos intrínsecos no processo de apoptose nas CTHs de pacientes com EM.

\section{- Sinalização Wnt}

A via de sinalização Wnt engloba família de proteínas glicosiladas ricas em cisteína envolvidas em vários processos básicos durante o desenvolvimento embrionário, como decisões de comprometimento celular, proliferação de células progenitoras e controle da divisão celular assimétrica. Nas CTHs, as proteínas Wnt não somente funcionam como fatores de crescimento indutores de proliferação, mas também afetam as decisões de comprometimento celular com linhagens específicas linfoides ou mieloides (STAAL et al., 2008; SUGIMURA et al., 2012).

As CTHs são responsáveis pela geração de todas as células dos sistemas hematopoético e imunológico. Para manter o pool de CTHs na medula óssea deve haver equilíbrio entre autorrenovação, quiescência e indução da diferenciação nos progenitores de linhagens específicas. Essa regulação depende de sinais provenientes do microambiente estromal ou nicho hematopoético e várias vias de sinalização vêm sendo implicadas na regulação dessas interações no nicho hematopoético (STAAL et al., 2008). Sinais provenientes de células do nicho formam complexa rede na qual as proteínas Wnt estão envolvidas. As funções das sinalizações canônica/não-canônica têm sido estudadas no processo de hematopoese, embora com alguns resultados controversos (KOKOLUS \& NEMETH, 2010; SUGIMURA et al., 2012).

A via de sinalização Wnt pode ser dividida em duas vias distintas, a canônica, dependente de $\beta$-catenina para induzir expressão gênica de seus alvos e a via nãocanônica, independente de $\beta$-catenina. A via canônica é altamente conservada e ativada pelas seguintes proteínas: Wnt1, Wnt3, Wnt3a, Wnt8a, Wnt8b, Wnt10a e Wnt10b. Uma vez ativada, a $\beta$-catenina é alvo da degradação no proteassoma através da fosforilação e 
ubiquitinação. Esse processo é mediado por um complexo de proteínas que inclue Axin1 e 2, proteína supressora tumoral APC, serina/treonina quinase Gsk3 e quinase caseína Ck1, que fosforilam a $\beta$-catenina. A degradação da $\beta$-catenina assegura baixa expressão dos alvos de Wnt por meio do recrutamento de repressores transcricionais, tais como histonas desacetilases (HDAC) e fatores como Tcf7, Lef1, Tcf3 e Tcf4. Após interação de Wnt aos seus ligantes Fz e correceptores Lrp5 ou 6 na superfície celular, o complexo de degradação da $\beta$-catenina, que se liga a Tcf1/Lef1 no núcleo, ativa a transcrição dos alvos de Wnt, dentre eles c-Myc, ciclina D1, Tcf1, Lef1 e Axin2 (ROOZEN et al., 2012).

A via de sinalização não-canônica de Wnt regula a polarização celular, controla a localização nuclear de NFAT através da concentração de $\mathrm{Ca}^{+2}$ ou CK1a, e ainda, suprime a via canônica de Wnt (MIKELS \& NUSSE, 2006; SUGIMURA et al., 2012). As proteínas Wnt da via não-canônica exercem funções dependentes dos receptores $F z$, relacionados com a regulação dos níveis de $\mathrm{Ca}^{+2}$ e translocação nuclear de NFAT, envolvido na ativação celular (NEMETH et al., 2007; SUGIMURA et al., 2012). Os receptores Ror e Ryk participam da via não-canônica e a ativação dessa via está envolvida na manutenção do estado quiescente das CTHs através da ligação de Fmi e Fz8, inibindo a via $\mathrm{Ca}^{+2}$ /NFAT e antagonizando a via canônica de Wnt (SUGIMURA et al., 2012). O Wnt5a atua nas duas vias canônica/nãocanônica e tem papel na manutenção das CTHs in vitro, e ainda, aumenta a eficiência de repopulação de CTHs humanas transplantadas em camundongos (NEMETH et al., 2007).

Alguns trabalhos têm mostrado o papel crucial da sinalização Wnt no nicho hematopoético. Staal e colaboradores (2008) mostraram que CTMs expressando Wnt3a suportam a hematopoese de forma dependente da sinalização Wnt pela indução da produção de proteoglicanos da matriz extracelular. Luis e colaboradores (2010) mostraram que o Wnt3a controla a função das CTHs de maneira parácrina e que sua deficiência conduz à completa ausência da sinalização canônica de Wnt. Esses achados indicam que o Wnt3a é proteína importante na ativação da via canônica nas CTHs, sendo molécula chave na expansão ex-vivo de CTHs para utilização em transplantes e terapia celular (LUIS et al., 2009; LUIS et al., 2010; SEKE ETET et al., 2013).

Estudos recentes observaram que a expressão de $\beta$-catenina expande o pool de CTHs em culturas de longa duração, sugerindo que as CTHs respondem à via canônica de Wnt em seu microambiente normal. Ademais, CTHs adultas expressando inibidores de Wnt, como Dkk-1, são incapazes de se autorrenovar. Outro trabalho mostrou que a expressão induzida de Dkk-1 em osteoblastos no nicho hematopoético diminui o pool de CTHs, alterando o nicho, com redução do volume ósseo trabecular (SEKE ETET et al., 2013). Além disso, foi mostrado que os osteoblastos são a principal fonte de Wnts no nicho estromal, expressando vários Wnts (Wnt1, Wnt4, Wnt7b e Wnt14) (SUGIMURA et al., 2012). 
Os trabalhos citados mostram que os mecanismos utilizados pela sinalização Wnt/ß-catenina na regulação do nicho hematopoético são complexos e envolvem a interação de outras vias de sinalização importantes, como a sinalização Notch. Estudos de expressão gênica de membros das duas vias, Wnt e Notch, durante o desenvolvimento hematopoético, mostraram a indução de genes da via Wnt no fígado fetal, relacionados com o potencial de proliferação dos progenitores hematopoéticos. Em adição, ocorre também indução de genes relacionados com a via de sinalização Notch na medula óssea, estando associados com a manutenção desses progenitores hematopoéticos em estado indiferenciado. Concluindo, estes trabalhos mostram que as vias de sinalização Wnt e Notch estão integradas e dirigem seletivamente a maturação dos progenitores hematopoéticos (SEKE ETET et al., 2013).

Além da interação com a sinalização Notch, o trabalho de Perry e colaboradores (2011) mostrou que as sinalizações Wnt/ $\beta$-catenina e PTEN/PI3K/AKT, em conjunto, interagem para induzir proliferação e expansão das CTHs, inibindo a apoptose e bloqueando a diferenciação. Esses achados demonstram a necessidade da cooperação entre essas vias de sinalização para promover autorrenovação e sobrevivênvia das CTHs na medula óssea (PERRY et al., 2011).

Nas nossas avaliações de enriquecimento funcional e identificação de vias de sinalização significantes (DAVID), alterações da expressão de genes envolvidos na sinalização Wnt foram encontradas, como a repressão de WNT5B, WNT6, WNT11 e dos receptores FZD2, FZD5 (receptor de Wnt5a), FZD9 e indução de TCF4, sugerindo possíveis alterações nos processos de autorrenovação e quiescência das CTHs na medula óssea de pacientes com EM.

\section{- Sinalização Notch}

Todas as células do sangue são derivadas das CTHs, que nos adultos residem na medula óssea. A maioria das células sanguíneas se desenvolve na medula óssea, com exceção dos linfócitos T, que têm sua maturação no timo. Para ambas as células, CTHs e linfócitos $\mathrm{T}$, as interações com o estroma do microambiente circundante são críticas para regulação e manutenção dessas células, além da regulação da diferenciação, apoptose e proliferação. Tais microambientes reguladores especializados são referidos como "nichos" e proporcionam interações de células do estroma com as células hematopoéticas, bem como a produção de fatores solúveis importantes para o desenvolvimento e maturação dessas células. Duas vias de sinalização, que são críticas para o desenvolvimento dos linfócitos $T$ são as vias Notch e Wnt (ROOZEN et al., 2012). 
A sinalização Notch foi identificada dentre as principais vias envolvidas na regulação e diferenciação das células-tronco, tendo papel essencial na hematopoese, regulando proliferação e diferenciação em vários estágios (ARTAVANIS-TSAKONAS et al., 1999; LIU et al., 2010; BIGAS \& ESPINOSA, 2012). A ativação da via Notch é dependente de interações célula-célula e da ligação com ligantes específicos (Jagged ou delta) a seus receptores (Notch 1-4) em células adjacentes (LIU et al., 2010). Durante a hematopoese, a sinalização Notch está diretamente envolvida com a diferenciação dos linfócitos (BIGAS \& ESPINOSA, 2012). A sinalização Notch participa da regulação da transcrição de vários genes, dentre eles, a família de fatores de transcrição Hes, que são inibidores da diferenciação celular. Acerca da função indutora da diferenciação de células $\mathrm{T}$, o fator de transcrição Hes1 parece ser necessário para os estágios iniciais de diferenciação dos linfócitos, enquanto outros alvos de Notch, como $p T \alpha$ e $I L 7 R$, são expressos e regulam estágios mais avançados da diferenciação dos linfócitos T (TALORA et al., 2003; GONZÁLES-GARCíA et al., 2009; BIGAS et al., 2010; BIGAS \& ESPINOSA, 2012).

Estudos mostram que nos estágios iniciais de diferenciação, alta atividade da sinalização Notch induz diferenciação de células $T$, enquanto baixa atividade induz diferenciação de células B (PIU et al., 1999; BIGAS \& ESPINOSA, 2012). Trabalhos também mostram que o bloqueio da sinalização Notch é suficiente para induzir síndromes mieloproliferativas (KLINAKIS et al., 2011). Por outro lado, mutações que induzem atividade exacerbada da via Notch são comumente encontradas em pacientes com leucemias de células T (ASTER et al., 2005; BIGAS \& ESPINOSA, 2012).

O trabalho de Yin e colaboradores (2012) mostrou expressão gênica e proteica aumentada de Notch1 e Hes1, componentes da via Notch, nas células CD34 de pacientes com psoríase, doença inflamatória crônica caracterizada pela hiperproliferação de queratinócitos epidermais. Além disso, eles mostraram que essas alterações intrínsecas das células precursoras persistem nas células que vão para a periferia. Utilizando sistemas de cultura estromal tímica, os autores diferenciaram células CD34 em linfócitos $\mathrm{T}$ in vitro e depois observaram suas funções, como proliferação e secreção de citocinas. Os linfócitos T diferenciados a partir de células CD34 de pacientes com psoríase mostraram maior taxa de proliferação e secreção de citocinas de padrão Th1. Além disso, células $T$ reguladoras diferenciadas a partir das células dos pacientes exibiam capacidade reduzida de inibir a proliferação de células efetoras e de produzir IL-2 e IL-10, sugerindo que as alterações encontradas nos linfócitos periféricos estão presentes desde a célula precursora (YIN et al., 2012).

Nas nossas análises de enriquecimento funcional e identificação de vias de sinalização significantes (DAVID), alterações da expressão de genes envolvidos na sinalização Notch foram encontradas, como a indução dos genes RBPJ, CIR1, ADAM17 e 
repressão dos genes CTBP1, NOTCH4, PSEN2 e HES5. Esses dados sugerem defeitos intrínsecos na sinalização Notch nas CTHs que podem persistir e influenciar nos processos tardios de diferenciação dos linfócitos T. Sugerimos ainda, que alterações nessa via de sinalização possam estar envolvidas com o desencadeamento de doenças autoimunes.

\section{- Sinalização mTOR}

Em conjunto com a sinalização Notch, estudos demonstraram que a sinalização mTOR desempenha funções na hematopoese e na diferenciação de linfócitos T (TANG et al., 2012). A ligação dos receptores Notch inicia diversas cascatas de sinalização, incluindo a fosfatidilinositol 3-quinase $(\mathrm{PI} 3 \mathrm{~K})$ e a da rapamicina (mTOR). A sinalização mTOR participa em duas vias bioquímicas distintas, mTORC1 e mTORC2 (LEE et al., 2012). O complexo mTORC1, composto por Raptor, GBL Pras40, é diretamente inibido por mTOR e promove crescimento celular e proliferação pela ativação da quinase S6K1 e inativação de 4EBP1, promovendo síntese proteica (INOKI et al., 2005; POLAK \& BUITENHUIS, 2012). O complexo mTORC2, composto por Rictor, GBL, Protor e Sin1, é inibido indiretamente por mTOR, ativa SGK1 e PKC e medeia a sinalização PI3K via ativação de Akt. (POLAK \& BUITENHUIS, 2012; GAMPER \& POWELL, 2012).

Os alvos da rapamicina (mTOR) apareceram como reguladores centrais na proliferação e maturação celular. Estudos recentes de vários grupos, revelaram o papel crítico de mTOR na hematopoese, diferenciação de linfócitos $T$, quiescência e sobrevivência das CTHs, sob condições homeostáticas (TANG et al., 2012).

A hiperativação da via de sinalização mTOR prejudica as funções das CTHs e está associada com o desenvolvimento de leucemias. O trabalho de Kalaitzidis e colaboradores (2012) mostrou que camundongos contendo CTHs deficientes em Raptor, componente do complexo mTORC1, exibiam acúmulo de células monocíticas, pancitopenia e esplenomegalia. Além disso, mostraram que Raptor é necessária para a autorrenovação das CTHs e desempenham papéis não-redundantes, juntamente com Rictor, do complexo mTORC2 (KALAITZIDIS et al., 2012). Em nosso trabalho, encontramos algumas alterações na expressão de moléculas do complexo mTORC1, como a repressão de MLST8 ou GBL e AKT1S1 ou PRAS40, sugerindo alterações no complexo mTORC1 da sinalização mTOR nas CTHs de pacientes com EM, enquanto que as expressões de RAPTOR e MTOR não estavam alteradas.

Estudos mostram que a deleção de Rictor, componente essencial de mTORC2, prejudica a proliferação e diferenciação das células pré-T dirigidas pela sinalização Notch, indicando o papel de mTORC2 na maturação das células T no timo, devido ao papel essencial de mTORC2 na sinalização Notch, regulando Akt e NF-kB (LEE et al., 2012). Em 
nosso trabalho, encontramos alterações significantes na expressão de moléculas do complexo mTORC2, como a indução de RICTOR, além da repressão de $M L S T 8$ ou $G B L$, PRR5 ou PROTOR1, MAPKAP1 ou SIN1, sugerindo alterações na expressão de moléculas envolvidas no complexo mTORC2 da sinalização mTOR nas CTHs de pacientes com EM.

Utilizando camundongos com dupla deleção de Raptor e Rictor, Tang e colaboradores (2012) mostraram a contribuição dos complexos mTORC1 e mTORC2 na linfopoese, mostrando que, principalmente a deleção de Rictor em timócitos diminuía drasticamente a celularidade no timo pela redução da proliferação de timócitos imaturos no estágio duplo negativo. A deficiência de Rictor afeta principalmente a linhagem de linfócitos $T$ e parece não afetar os linfócitos $B$, eritrócitos e células mieloides, mostrando o papel essencial do complexo mTOC2 na linfopoese de células T (TANG et al., 2012).

O complexo TSC (TSC1/TSC2) da sinalização mTOR é regulador chave do metabolismo celular. O trabalho de Chen e colaboradores (2008) mostrou que camundongos deficientes em tsc1 apresentavam diminuição da quiescência e rápida proliferação das CTHs, acompanhada de aumento da biogênese mitocondrial e de elevados níveis de espécies reativas do oxigênio. Por meio de transplantes seriados, foi demonstrado que a ausência de tsc1 diminuía a autorrenovação das CTHs e hematopoese, mas que estas alterações eram restauradas tratando os camundongos com rapamicina. Esse trabalho mostra que a sinalização TSC-mTOR é importante na manutenção da quiescência e função das CTHs (CHEN et al., 2008). Em nosso estudo, encontramos indução significante da expressão de TSC1 e repressão de TCS2 nas CTHs dos pacientes com EM, sugerindo alterações na ativação de Rheb, molécula intermediária que participa na ativação das duas vias de mTOR, mTORC1 e mTORC2.

Nas nossas análises de processos biológicos (GSEA) e vias de sinalização significantes (DAVID e INGENUITY), alterações da expressão gênica envolvidas com a via de sinalização mTOR apareceram em todas as análises in silico realizadas e alterações da expressão de genes de quase toda a via foram encontradas, sugerindo defeitos intrínsecos nesta sinalização nas CTHs de pacientes com EM, e que podem estar envolvidos com o desenvolvimento da doença.

\section{- Sinalização PI3K/AKT}

As vias de sinalização que envolvem PI3K/Akt/mTOR são centrais na regulação de vários processos celulares. As perturbações dessas cascatas de sinalização estão sendo implicadas em desordens hematológicas, doenças inflamatórias e autoimunes (FOSTER et al., 2012; MAGEE et al., 2012). 
Desde que foi demonstrado que a via PI3K desempenha papel essencial na proliferação, sobrevivência e diferenciação de diferentes tipos celulares, surgiram também trabalhos mostrando o seu papel essencial na manutenção das CTHs, através da utilização de modelos animais deficientes em PTEN e SHIP1, inibidores da atividade de PI3K. A atividade de PI3K pode ser inibida por PTEN, pela desfosforilação de PIP3 e da mesma forma, por SHIP1, proteína expressa predominantemente em células hematopoéticas, que hidroliza PIP3, inibindo a sinalização PI3K. A inibição farmacológica de PI3K em células CD34 humanas isoladas de sangue de cordão umbilical suprime a proliferação e diferenciação dos progenitores que dão origem a neutrófilos e eosinófilos, conduzindo a apoptose. Esses dados mostram a importância da regulação da sinalização mediada por PI3K na manutenção das CTHs e na regulação do desenvolvimento das linhagens progenitoras (POLAK \& BUITENHUIS, 2012). Em nosso trabalho, encontramos indução significativa da expressão de $P T E N$, sugerindo alterações na ativação da via de sinalização PI3K/AKT nas CTHs de pacientes com EM, sinalização essa envolvida na manutenção das CTHs na medula.

Um importante mediador da sinalização PI3K é a proteína quinase AKT1(PKB), que está localizada no citoplasma em células não estimuladas e é translocada para a membrana quando fosforilada por PDK1, após ativação de PI3K. Análises de CTHs derivadas de camundongos duplo deficientes em PKB $\alpha /$ PKB $\beta$ revelaram que AKT1 desempenha papel importante na manutenção das CTHs. As CTHs desses camundongos deficientes permaneciam na fase $\mathrm{GO}$ do ciclo celular, sugerindo que os defeitos funcionais observados nesses camundongos, com relação à hematopoese, eram causados pela quiescência acentuada das CTHs. Por outro lado, a expressão ectópica de akt1 nas CTHs dos camundongos resultava na expansão e aumento do ciclo celular nas CTHs, seguido de apoptose e expansão de progenitores ainda imaturos na medula óssea. Além do papel na manutenção das CTHs, AKT1 também desempenha papéis críticos na regulação do comprometimento celular durante $\mathrm{o}$ desenvolvimento das diferentes linhagens hematopoéticas. A alta atividade de AKT1 nos progenitores hematopoéticos humanos isolados de sangue de cordão umbilical promove a diferenciação de monócitos e neutrófilos e inibe o desenvolvimento de linfócitos $B$, enquanto a redução da atividade de AKT1 mostrou-se necessária para a maturação eosinofílica (LEE et al, 2010; POLAK \& BUITENHUIS, 2012). Em nosso trabalho, encontramos repressão de $A K T 1$, sugerindo possíveis alterações na ativação de moléculas situadas abaixo da sinalização de AKT.

Estudos demonstram que as moléculas abaixo da sinalização de AKT1 também regulam diferencialmente a hematopoese, incluindo membros dos fatores de transcrição Foxo, a quinase GSK3 e as quinases alvo da rapamicina (mTOR), do complexo de sinalização mTORC1. Os fatores de transcrição Foxo, que são inibitórios quando 
fosforilados por AKT1 são conhecidos por desempenhar papéis importantes na regulação da proliferação e sobrevivência de vários tipos celulares (MAGEE et al., 2012). Ademais, estudos em camundongos deficientes em foxo1, foxo3 e foxo4, mostraram o papel essencial desses fatores na manutenção das CTHs. A deficiência desses fatores promovia diminuição no número de CTHs, aumento do número de células mieloides, diminuição dos números de linfócitos no sangue periférico e capacidade de repopulação reduzida. Esses camundongos desenvolvem leucocitose, caracterizada pela relativa neutrofilia e linfopenia, mostrando o papel essencial desses fatores de transcrição na hematopoese normal (TOTHOVA et al., 2007; POLAK \& BUITENHUIS, 2012). Em nosso trabalho, encontramos que FOXO1 estava induzido e FOXO4 estava reprimido nas CTHs dos pacientes com EM, sugerindo possíveis alterações na função de manutenção das CTHs exercidas por esses genes.

Achados recentes demonstraram que a regulação da atividade de GSK3, que é inibido por AKT1, é essencial na manutenção das CTHs, visto pela alteração na população de CTHs em camundongos deficientes em GSK3 (POLAK \& BUITENHUIS, 2012). Em nosso trabalho, não encontramos alterações na expressão de GSK3 nas CTHs de pacientes com EM.

O terceiro e importante mediador da sinalização PI3K/AKT é a sinalização mTOR. Ao contrário de Foxo e GSK3, que são inibidos por AKT1, a atividade de mTOR é positivamente regulada por AKT1. A inibição do complexo TSC1/TSC2 por AKT1 resulta no acúmulo de Rheb e subsequente ativação de mTOR. A deleção de tsc1 em camundongos, resulta na ativação de mTOR e redução da capacidade de autorrenovação das CTHs. Diferente de AKT1, que regula proliferação e diferenciação de progenitores mieloides, a sinalização mTOR regula a expansão dos progenitores hematopoéticos. Em conjunto, os dados mostram que os fatores de transcrição Foxo, GSK3 e a sinalização mTOR são mediadores importantes de PI3K/AKT para a manutenção das CTHs e desenvolvimento das linhagens celulares específicas (POLAK \& BUITENHUIS, 2012).

Nas nossas análises de vias de sinalização significantes (INGENUITY), alterações da expressão gênica envolvidas com a via de sinalização PI3K/AKT foram identificadas e a expressão de vários genes abaixo dessa via estavam desregulados, sugerindo defeitos intrínsecos nesta sinalização nas CTHs de pacientes com EM.

\section{- Sinalização Calcineurina/NFAT}

O cálcio regula a cascata de sinalização calcineurina/NFAT, sendo essencial para regulação da função das CTHs e para controle da imunidade adaptativa, pois está envolvido na ativação dos linfócitos T (WANG \& WAGERS, 2011). Além disso, os fatores de transcrição NFAT parecem estar envolvidos com a indução de tolerância periférica a 
autoantígenos, mostrando o papel dessas moléculas na tolerância imunológica e o envolvimento de sua desregulação no desencadeamento de DAls (SERFLING et al., 2006; FRIC et al., 2012). Os fatores de transcrição NFAT compreedem família de proteínas altamente fosforiladas, presentes no citoplasma de células em repouso, que regulam o desenvolvimento, ativação e diferenciação de linfócitos T (MÜLLER et al., 2009; FRIC et al., 2012). Além disso, a sinalização NFAT também medeia ativação de granulócitos e células dendríticas (FRIC et al., 2012).

Após a desfosforilação pela fosfatase calcineurina, as proteínas NFAT translocamse para o núcleo, onde regulam programas de desenvolvimento e ativação de diversos tipos celulares. NFAT é refosforilado e inativado através da ação conjunta de pelo menos três diferentes quinases CK1, GSK3 e DYRK. Os principais sítios de ligação para a calcineurina e CK1 são altamente conservados nos vertebrados. A conversão do sítio de ligação da calcineurina para versão de alta afinidade ou do sítio de ligação de CK1 para versão de baixa afinidade resultam na geração de proteínas NFAT hiperativas e altamente responsivas à estimulação (MÜLLER et al., 2009). Estudos mostraram que a hiperativação de NFAT afeta a diferenciação de células $T$ no timo e é deletéria para o desenvolvimento de linfócitos B a partir dos progenitores hematopoéticos, mostrando a importância do equilíbrio da sinalização de Ca/NFAT na hematopoese e que a ativação inapropriada dessa via pode alterar esse processo (FRIC et al., 2012).

No trabalho de Fric e colaboradores (2012), foi demonstrado que camundongos irradiados e reconstituídos com células hematopoéticas expressando inibidores de NFAT apresentaram maior desenvolvimento do compartimento mieloide, mostrando o papel da sinalização Ca/NFAT como reguladores negativos do desenvolvimento da linhagem mieloide durante a hematopoese. Além disso, trabalhos mostram que a deleção de receptores para íons de cálcio nas CTHs impedem seu alojamento na medula óssea e diminui a celularidade (ADAMS et al., 2006). Por outro lado, a estimulação farmacológica desses receptores para íons de cálcio, aumenta a migração das CTHs para a medula e o enxerto, sugerindo que íns de cálcio funcionam como quimioatraentes para as CTHs (LAM et al., 2011; WANG \& WAGERS, 2011).

Em nosso trabalho, encontramos indução da expressão dos genes $D Y R K 1 A$ ou DYRK, CALM1, NFATC2 e repressão de CAML3 e NFATC1, sugerindo alterações na via de sinalização Ca/NFAT nas CTHs de pacientes com EM, que podem estar relacionadas a alterações no processo de migração e enxertia das CTHs na medula óssea após transplantes. Além disso, alterações na via de sinalização Ca/NFAT podem persistir após os processos de diferenciação em linhagens específicas, como a de linfócitos $\mathrm{T}$, podendo influenciar em processos tardios, tais como a tolerância imunológica. 
Nas nossas análises de processos biológicos significantes (GSEA), alterações da expressão de genes envolvidos com a via de sinalização Ca/NFAT foram identificadas, sugerindo defeitos intrínsecos nesta sinalização nas CTHs de pacientes com EM.

Concluindo, as CTHs isoladas de pacientes com EM apresentaram perfil de expressão gênica diferencial em relação às CTHs isoladas de doadores saudáveis, exibindo alterações em genes pertencentes a vias de sinalização importantes para a manutenção, quiescência, migração, proliferação e posterior diferenciação em linhagens específicas. Inicialmente, os transplantes de CTHs autólogas em DAls foi idealizado acreditando-se que poderiam representar cura para esses pacientes. No entanto, atualmente, sabe-se que elas possuem grande capacidade de reconstituição do sistema imune e hematopoético, evitando citopenias prolongadas, mas não representam cura da doença. Por outro lado, estudos experimentais mostraram transferência de DAls após transplante de medula óssea em camundongos (IKEHARA et al., 1994; IKEHARA, 1998; IKEHARA, 2003; IKEHARA, 2008), e trabalhos clínicos mostraram que pacientes com doença hematológica e autoimune associadas melhoravam das DAls com o transplante alogênico (DOMENICK \& ILDSTAD, 2001). Com base nesses trabalhos e nas diversas alterações relevantes que encontramos nas CTHs dos pacientes com EM, acreditamos que o transplante alogênico poderia representar cura para os pacientes com DAls. No entanto, face às diversas complicações relacionadas à rejeição em transplantes alogênicos, ainda acreditamos que o TACTH deva ser mantido para os casos refratários aos imunomoduladores, uma vez que proporciona, juntamente com a imunossupressão, estabilização da progressão neurológica e melhora clínica de pacientes com EM.

\subsection{CARACTERIZAÇÃO DAS CÉLULAS ESTROMAIS MESENQUIMAIS}

De acordo com a Sociedade Internacional de Terapia Celular, as células estromais mesenquimais multipotentes (CTMs) são caracterizadas por três critérios: i) capacidade de aderência ao plástico quando em cultura e morfologia fibroblastoide; ii) expressão dos marcadores imunofenotípicos CD105, CD73, e CD90 e ausência de expressão de CD34, CD45, CD14, CD19 e HLA-DR em mais de 95\% das células em cultura e; iii) capacidade de diferenciação em células da linhagem mesodérmica, como osteócitos, adipócitos e condrócitos (HORWITZ et al., 2005; DOMINICl et al., 2006, LE BLANC \& MOUGIAKAKOS, 2012).

As CTMs isoladas da medula óssea de doadores saudáveis ou de pacientes pré- e pós-transplante demonstraram capacidade de aderência ao plástico em cultura, morfologia fibroblastoide, expressão dos principais marcadores imunofenotípicos, além da capacidade 
de diferenciação em adipócitos e osteócitos, conforme descrito na literatura (LE BLANC \& PITTENGER, 2005; DOMINICl et al., 2006).

Em nosso estudo, além dos marcadores celulares característicos de CTMs recomendados pela Sociedade Internacional de Terapia Celular, acrescentamos outros também característicos dessas células. Assim, as CTMs isoladas de pacientes com EM nos períodos pré- e pós-TACTH apresentaram imunofenótipo característico de CTMs com alta expressão de CD90, CD13, CD29, CD105, CD73, CD44, CD166 e HLA-ABC; expressão intermediária de CD146, CD54 e CD106; baixa expressão de HLA-DR; e ausência dos marcadores CD14, CD34, CD31 e CD45. As porcentagens de CTMs positivas para esses marcadores, dos indivíduos saudáveis e pacientes (pré e pós-TACTH) foram semelhantes às descritas na literatura (LE BLANC \& PITTENGER, 2005; DOMINICI et al., 2006; KERN et al., 2006). No entanto, foi observada redução da expressão dos marcadores CD29, CD105, CD73 e CD44 nas CTMs de pacientes (pré- e pós-TACTH) e diminuição dos marcadores CD166, HLA-ABC e CD146 nas CTMs dos pacientes (pós-TACTH) quando comparadas à expressão desses mesmos marcadores nas CTMs de indivíduos saudáveis. Inicialmente, sugerimos que a diminuição significativa da expressão de alguns desses marcadores nas CTMs dos pacientes poderia estar relacionada com a idade das células, uma vez que a média de idade dos pacientes com EM (pré-TACTH: 38,2 \pm 9,3 anos; pós-TACTH: 39,3 \pm 8,1 anos) é maior que a dos doadores saudáveis (34,0 $\pm 10,7$ anos).

O potencial de regeneração tecidual das células-tronco diminui com a idade (ROSSI et al., 2008). O trabalho de Wagner e colaboradores (2009) analisou o efeito da idade no perfil de expressão gênica em CTMs. Os autores avaliaram CTMs isoladas de doadores saudáveis com idades variando de 21 a 92 anos, relatando nos doadores com idade mais avançada, indução, principalmente, de genes relacionados com senescência celular e repressão de genes envolvidos com integridade genômica, sugerindo que a idade possa interferir na capacidade regenerativa das células-tronco adultas. Com relação à caracterização das CTMs, Wagner e colaboradores (2009) não encontraram diferenças significantes quanto à morfologia, potencial de diferenciação multipotencial e expressão de marcadores imunofenotípicos em CTMs de doadores saudáveis mais velhos, comparados aos doadores mais novos (WAGNER et al., 2009). Embasados nesse estudo, podemos sugerir que, a redução na expressão de marcadores imunofenotípicos nos nossos pacientes com EM possa não ter relação com idade avançada, mas sim com características da própria doença, ou ainda, efeitos de tratamentos prévios com imunossupressores/imunomoduladores no microambiente medular, que poderiam alterar a expressão dessas moléculas na superfície das CTMs. 
De maneira similar, a redução da expressão de alguns marcadores imunofenotípicos das CTMs de pacientes (pós-TACTH) pode estar relacionada com a imunossupressão intensa da fase de condicionamento.

Os trabalhos de Mazzanti (2008) e Zafranskaya e colaboradores (2012) não encontraram diferenças significantes na expressão dos marcadores imunofenotípicos nas CTMs isoladas da medula óssea de pacientes com EM, diferentemente de nosso trabalho. No estudo de Zafranskaya e colaboradores (2012) os pacientes ficaram seis meses sem qualquer tratamento com imunomoduladores. Em nosso trabalho e no de Mazzanti e colaboradores (2008), os pacientes ficaram um mês sem o tratamento com imunomoduladores até a data de coleta da medula óssea.

Concluindo, as CTMs isoladas da medula óssea de pacientes com EM pré- e pósTACTH apresentaram capacidade de aderência ao plástico, porém com aparência de células senescentes, expressão reduzida de marcadores imunofenotípicos, e ainda, capacidade de diferenciação multipotencial semelhante às CTMs controle. Com base em algumas dessas alterações, o uso de CTMs de pacientes com EM poderia ser questionável.

\subsection{ANÁLISE DA EXPRESSÃO GÊNICA NAS CÉLULAS ESTROMAIS MESENQUIMAIS}

A utilização de CTMs derivadas da medula óssea vem sendo considerada como importante fonte autóloga para terapia celular em DAls, devido as suas propriedades imunossupressoras e imunomoduladoras (DAZZI et al., 2007; PAYNE et al., 2007; LIU et al., 2012; UCCELLI et al., 2012; COHEN, 2013). A capacidade das CTMs de modular a resposta das células do sistema imune sugere o possível papel dessas células na indução de tolerância imunológica em pacientes com DAls e oferece suporte para a base racional de sua aplicação no tratamento de pacientes com EM (DAZZI et al., 2012; DE MIGUEL et al., 2012).

No entanto, não se sabe se as CTMs isoladas da medula óssea de pacientes com EM são normais ou defeituosas em relação às características fenotípicas, genéticas e funcionais, quando comparadas as células isoladas de indivíduos saudáveis. Não existem dados na literatura sobre o perfil de expressão gênica de CTMs isoladas da medula óssea de pacientes com EM. O trabalho de Papadaki e colaboradores (2005) mostrou que CTMs de pacientes com EM eram capazes de suportar a hematopoese de células CD34 autólogas, da mesma forma que as células controle, e ainda, não encontrou diferenças na secreção de CXCL-12 e SCF pelas CTMs de pacientes e cotroles. No entanto, esses autores não avaliaram perfil de expressão gênica e capacidade supressora das CTMs de pacientes com EM invitro. Estudos em outras DAls mostraram que CTMs de pacientes com esclerose sistêmica apresentam funções normais (LARGHERO et al., 2008), no entanto, outros 
trabalhos mostraram que CTMs de pacientes com artrite reumatóide e com lúpus eritematoso sistêmico apresentam funções alteradas (PAPADAKI et al., 2002; SUN et al., 2007).

Existem alguns trabalhos na literatura comparando o perfil de expressão gênica de CTMs isoladas da medula óssea e da veia de cordão umbilical de doadores saudáveis (PANEPUCCl et al., 2004), bem como comparando-as às CTHs (SILVA et al., 2003) e descrevendo alterações moleculares durante a diferenciação adipogênica (MENSSEN et al., 2011), osteogênica (KULTERER et al., 2007) e condrogênica (YOO et al., 2011).

O trabalho de Panepucci e colaboradores (2004) comparou CTMs isoladas da medula óssea com CTMs obtidas a partir da veia de cordão umbilical, mostrando que essas células são similares, mas possuem alguns genes diferencialmente expressos, particularmente aqueles relacionados com osteogênese nas CTMs da medula óssea e genes associados com angiogênese nas CTMs isoladas da veia de cordão.

O trabalho de Silva e colaboradores (2003) comparou as CTMs isoladas de medula óssea com as CTHs e demonstrou que os genes diferencialmente expressos nas CTMs se enquadravam em categorias como, moléculas de adesão celular, motilidade celular, sinalização do TGF- $\beta$, receptores de fatores de crescimento, reparo de DNA, ubiquitinação e dobramento de proteínas.

Em nosso trabalho, encontramos 618 genes diferencialmente expressos $(P<0,01$; $F C \geq 2,0$ ) nas $C T M s$ dos pacientes com EM em relação às células de indivíduos saudáveis. Esses genes estavam envolvidos em diversos processos biológicos e em vias de sinalização importantes para manutenção de células-tronco e vias relacionadas com adesão celular e atividade imunomoduladora. Esses resultados sugerem que as CTMs de pacientes com EM possuam alterações intrínsecas que podem interferir no nicho hematopoético e na sustentação das CTHs, bem como na capacidade de modular as respostas das células do sistema imune. Dentre os processos biológicos significantes, encontramos genes relacionados à interação citocinas/receptores de citocinas e sinalização da IL-10. Dentre as vias canônicas significantes encontramos alterações na via do FGF (fibroblast growth factor) e do HGF (hepatocyte growth factor), que desempenham papéis importantes na manutenção das CTMs e na função imunomoduladora, respectivamente.

Ainda, em nosso trabalho, encontramos 81 genes diferencialmente expressos nas CTMs dos pacientes com EM após o TACTH em relação às CTMs de pacientes antes do transplante. A maioria desses genes estavam induzidos nas células dos pacientes pósTACTH e se enquadravam em categorias como: processos metabólicos do DNA, replicação do DNA, complexo de ribonucleoproteínas, constituintes estruturais dos ribossomos, montagem de proteínas complexas e biogênese de complexo de proteínas. Não existem 
dados na literatura comparando perfis de expressão gênica de CTMs de pacientes com EM submetidos ao transplante autólogo de células-tronco hematopoéticas.

As CTMs apresentam propriedades importantes de imunossupressão e imunorregulação in vitro e in vivo. Elas apresentam capacidade de modular a função de várias populações celulares do sistema imune, incluindo inibição das seguintes atividades: i) citotoxicidade das células NK, ii) maturação das células dendríticas pela diminuição da produção de TNF e expressão de moléculas coestimuladoras, interferindo na apresentação de antígenos (UCCELLI et al., 2006; UCCELLI et al., 2008; MEIRELLES et al., 2009; LE BLANC \& MOUGIAKAKOS, 2012). Adicionalmente, mostrou-se que as CTMs mudam o padrão de citocinas liberadas em cocultura com monócitos, diminuindo a produção de citocinas pró-inflamatórias como TNF, IFN- $\gamma$, IL-12 e aumentando a produção de IL-10 (NAUTA \& FIBBE, 2007). Além disso, inibem diretamente a proliferação de linfócitos T CD4 e T CD8 e linfócitos $B$, inibem a citotoxicidade de linfócitos T CD8, inibem a produção de anticorpos e induzem a geração de células T reguladoras pela produção de TGF- $\beta$ e HLAG5 (DAZZI et al., 2012, LE BLANC \& MOUGIAKAKOS, 2012; BURR et al., 2013).

Vários mecanismos vêm sendo evidenciados como responsáveis pela capacidade imunomoduladora das CTMs e, atualmente, há consenso de que a secreção de fatores solúveis por essas células desempenhe papel fundamental na sua atividade supressora. Alguns desses fatores solúveis são produzidos constitutivamente pelas CTMs e outros são induzidos após o licenciamento das CTMs em microambientes inflamatórios específicos (DAZZI et al., 2012). Dentre esses fatores solúveis estão a IDO (indoleamina 2,3dioxigenase), prostaglandina E2 (PGE2), TGF- $\beta 1$, IL-6, HGF, LIF (leukemia inhibitory factor) e HLA-G5, além de metaloproteinases e quimiocinas, que estão envolvidas no processo de imunomodulação (UCCELLI et al., 2008; BASSI et al., 2012; DAZZI et al., 2012).

A IDO é produzida pelas CTMs estimuladas por IFN- $\gamma$ e induz a depleção do triptofano, aminoácido essencial para a proliferação dos linfócitos. Além do IFN- $\gamma$, outras citocinas pró-inflamatórias como TNF, IL-1 $\alpha$ e IL-1 $\beta$ induzem as CTMs a produzirem fatores solúveis que inibem a proliferação dos linfócitos. Alguns fatores solúveis como TGF- $\beta 1$, HGF, PGE2, IL-6 são constitutivamente produzidos pelas CTMs, e alguns deles podem ter sua produção aumentada pelas citocinas pró-inflamatórias do microambiente, promovendo o licenciamento das CTMs, principalmente via receptores de IFN- $\gamma$ (DAZZI et al., 2012, LE BLANC \& MOUGIAKAKOS, 2012). Recentemente, foi demonstrado o envolvimento de outra molécula, a HLA-G5, na regulação imune mediada pelas CTMs. A produção HLA-G5 na forma solúvel é estimulada pela IL-10 e leva à supressão da proliferação de linfócitos $T$, bem como da citotoxicidade de células $\mathrm{NK}$ e $\mathrm{T} \mathrm{CD} 8^{+}$, além de promover a geração de células $\mathrm{T}$ reguladoras (DAZZI \& MARELLI-BERG, 2008; UCCELLI et al., 2008; DAZZI et al., 2012). 
Foi demonstrado que anticorpos neutralizantes contra o TGF- $\beta$ interferem na capacidade imunomoduladora das CMTs sobre os linfócitos T e células NK. De maneira similar, anticorpos neutralizantes do HGF revelaram que essa molécula também é responsável por mediar os efeitos antiproliferativos das CTMs sobre os linfócitos. Dentre outras moléculas que medeiam os efeitos imunorreguladoras das CTMs estão HLA-G e LIF, essa última desempenhando importante papel não só na supressão da proliferação de linfócitos $T$, mas também na geração e manutenção de células T reguladoras (DI IANNI et al., 2008; NASEF et al., 2008; DE MIGUEL et al., 2012).

Nas nossas análises de enriquecimento funcional e processos biológicos significantes (GSEA), foram encontradas alterações da expressão de genes da categoria sinalização citocinas/receptores nas CTMs de pacientes com EM. Dentre estas alterações, destacam-se alterações de genes envolvidos com a capacidade imunomoduladora das CTMs, como a repressão de TGFB1 e HGF e indução de IL10, IL6, IFNGR1 e IFNGR2, sugerindo defeitos intrínsecos nas CTMs de pacientes com EM que podem interferir na sua capacidade imunossupressora/imunorreguladora.

Além disso, nas análises de vias de sinalização significantes (INGENUITY), encontramos alteração na via de sinalização do HGF, fator solúvel importante na capacidade antiproliferativa das CTMs. Nessa via, encontramos a repressão do HGF, além de moléculas sinalizadoras intracelulares como $P L C \gamma, P I 3 K, A K T, C R K L, C D C 42$ e CDK2, envolvidas na progressão do ciclo celular. Foi observada também, indução de IL6, que se encontra à jusante da sinalização do HGF, e também de RAS, PKC e RAP1, relacionados com adesão e migração celular.

O trabalho de Ren e colaboradores (2011) comparou o perfil de expressão gênica de CTMs isoladas da medula óssea, linhagens de fibroblastos, células-tronco embrionárias e células $\mathrm{CD}_{3}{ }^{+}$e observou que os genes diferencialmente expressos e induzidos nas CTMs estavam envolvidos com movimentação celular, sinalização célula-célula, proliferação celular, sinalização da integrina, resposta ao estresse oxidativo, reorganização do citoesqueleto e sinalização $W n t / \beta$-catenina. Dentre os genes com alterações mais importantes da expressão estavam genes estruturais, componentes da matriz extracelular, integrinas $\alpha 5$ e $\beta 5$, fibronectina e colágenos tipo Ill $\alpha 1$ e $\vee \alpha 1$, proteínas funcionais da matriz como o fator de crescimento CTGF, TGF- $\beta 1$, desintegrina A e a metaloproteinase ADAM12. Esse trabalho mostra que as CTMs produzem proteínas abundantes da matriz extracelular que contribuem para seus efeitos imunomoduladores e anti-inflamatórios em aplicações clínicas (REN et al., 2011). Em nosso trabalho, encontramos indução da expressão de CTGF e repressão de COL3A1 e TGFB1, indicando alterações na expresssão de moléculas de adesão envolvidas no processo de imunomodulação nas CTMs de pacientes com EM. 
Ademais, em nossas análises de vias de sinalização significantes (INGENUITY), foram encontradas alterações da expressão de genes pertencentes à sinalização FGF nas CTMs de pacientes com EM quando comparadas as CTMs isoladas de doadores saudáveis.

Vários trabalhos têm mostrado que os fatores de crescimento possuem efeitos reguladores nas CTMs, e dentre esses, estão incluídos membros da superfamília do TGF- $\beta$, da família dos IGFs (insulin-like growth factors) (MATSUDA et al., 2005), fatores de crescimento de fibroblastos FGFs (fibroblast growth factors) (ITO et al., 2008), fatores de crescimento epidermal EGFs (epidermal growth factors) (KRATCHMAROVA et al., 2005), fatores de crescimento derivados de plaquetas PDGFs (platelet-derived growth factors), fatores de crescimento vascular endotelial VEGFs (vascular endothelial growth factors) (LIU et al., 2007) e a família de fatores de crescimento conhecidos como Wnts (LIU et al., 2009).

Os fatores de crescimento de fibroblastos (FGFs) estimulam uma variedade de respostas biológicas, como proliferação celular, diferenciação e migração (FARRÉ et al., 2007). Em nosso trabalho, encontramos alterações na expressão de vários genes da sinalização FGF nas CTMs dos pacientes com EM, como a repressão de FGF3, FGFBP3, FGFR1 e indução de FGF2, além de outras moléculas envolvidas na sinalização como a repressão de GAB1, AKT2, PTPN11 ou SHP2, sugerindo alterações na sobrevivência, proliferação e migração das CTMs de pacientes com EM.

Concluindo, as CTMs isoladas de pacientes com EM possuem perfil de expressão gênica diferente das CTMs isoladas de indivíduos saudáveis, com alterações da expressão em genes e vias de sinalização importantes para a manutenção das CTMs, adesão e migração celular, e ainda, para os processos de imunossupressão/imunorregulação mediados pelas CTMs. Esses achados sugerem que as CTMs isoladas de pacientes com EM possam não alcançar os efeitos desejados em aplicações clínicas autólogas, e uma vez que, as CTMs são pobremente reconhecidas pelo sistema imune, isto é, são consideradas células com baixa imunogenicidade, poderiam ser transplantadas de forma alogênica, sendo obtidas de doadores saudáveis de medula óssea. Na literatura, encontramos apenas um trabalho utilizando CTMs alogênicas isoladas de cordão umbilical no tratamento de uma paciente com EM progressiva primária, mostrando bons resultados, como diminuição do EDSS após 6 meses e diminuição significativa das lesões cerebrais, especialmente na medula cervical (LIANG et al., 2009). Assim, estudos clínicos mais abrangentes são necessários para avaliar a eficácia das CTMs de doadores saudáveis em pacientes com EM. 


\subsection{CAPACIDADE DE INIBIÇÃO DA PROLIFERAÇÃO DE LINFÓCITOS ALOGÊNICOS}

As atividades imunossupressora e imunomoduladora das CTMs, in vivo e in vitro, têm sido extensivamente demonstradas na literatura (BARTHOLOMEW et al., 2002; RASMUSSON et al., 2003; AGGARWAL \& PITTENGER, 2005; AUGELLO et al., 2005; DAZZI et al., 2012). As CTMs são capazes de inibir a proliferação de linfócitos T e B induzida por mitógenos e também de suprimir a reatividade linfocitária em cultura mista de linfócitos (DI NICOLA et al., 2002; KRAMPERA et al., 2003; CORCIONE et al., 2006). Le Blanc e colaboradores (2003) mostraram que as CTMs exercem efeito imunossupressor em culturas mistas de linfócitos, nas quais, em elevadas proporções, suprimem a alorreatividade das células T, com redução da proliferação de linfócitos induzida por PHA. Ademais, foi visto que a capacidade supressora das CTMs depende da produção de IL-1 $\beta$ pelos monócitos, pois essa citocina induz as CTMs a produzirem TGF- $\beta 1$, citocina anti-inflamatória envolvida com a supressão de linfócitos (GROH et al., 2005; UCCELLI et al., 2008; LE BLANC \& MOUGIAKAKOS, 2012).

Em nosso trabalho, os resultados relativos à porcentagem de proliferação e porcentagem de inibição da proliferação de CMNs alogênicas, em conjunto, indicam diminuição dose-dependente da proliferação dos linfócitos na presença de números crescentes de CTMs isoladas de doadores saudáveis, dado esse de acordo com dados encontrados na literatura (DI NICOLA et al., 2002; RASMUSSON et al, 2005; SUVA et al., 2008). Trabalhos recentes confirmam e demonstram que as CTMs isoladas de indivíduos saudáveis são capazes de inibir a proliferação de linfócitos de maneira dose e contatodependente, atingindo porcentagem de inibição de $60 \pm 5 \%$ na proporção 1/1 (NAJAR et al., 2010), enquanto nossos resultados mostraram inibição de $69,4 \pm 7,2 \%$ na proporção $1 / 2$.

O trabalho de Zafranskaya e colaboradores (2012) mostrou que as CTMs isoladas de pacientes com EM inibem a proliferação de linfócitos autólogos e alogênicos na proporção 1/10 sem diferenças estatísticas entre esses dois grupos de ensaios. No entanto, os autores mostraram que a capacidade supressora das CTMs era significativamente maior sobre células mielina-específicas do que para estímulos policlonais. Além disso, eles encontraram correlação inversa entre a capacidade de inibição e os valores de EDSS, ou seja, quanto maiores os valores de EDSS, menor a capacidade de inibição da proliferação de linfócitos antígeno-específicos (ZAFRANSKAYA et al., 2012).

Os nossos resultados relativos à porcentagem de proliferação e porcentagem de inibição da proliferação de CMNs alogênicas indicaram diminuição dose-dependente da proliferação dos linfócitos na presença de números crescentes de CTMs isoladas de pacientes com EM pré- e pós-TACTH. Em adição, não encontramos correlação da capacidade de inibição da proliferação de linfócitos alogênicos com os valores de EDSS dos 
nossos pacientes nos períodos pré- e pós-TACTH. Não existem dados na literatura sobre a capacidade antiproliferativa de CTMs isoladas de pacientes com EM que foram submetidos a terapia de imunossupressão em altas doses seguida do TACTH.

Em nossas análises, observamos que a capacidade antiproliferativa das CTMs de doadores saudáveis é significativamente maior na proporção $1 / 2$ (aproximadamente $70 \%$ de inibição) quando comparada à das CTMs de pacientes pré-transplante (aproximadamente $50 \%$ de inibição) na mesma proporção, sugerindo que, possivelmente, as CTMs de pacientes com EM tenham alguma alteração que interfira na sua capacidade imunossupressora (alterações na liberação de fatores solúveis e/ou alterações na expressão de receptores que participam na inibição célula-célula). Estes dados, todavia, são contrários aos encontrados por Mazzanti e colaboradores (2008), que demonstraram que a capacidade inibitória de CTMs isoladas de pacientes com EM e de indivíduos saudáveis era igual quando essas eram adicionadas em culturas mistas de linfócitos (MAZZANTI et al., 2008).

A capacidade antiproliferativa de CTMs isoladas de pacientes com outras doenças autoimunes (artrite reumatóide, esclerose sistêmica e síndrome de Sjögren) já havia sido testada anteriormente por Bocelli-Tyndall e colaboradores (2007), demonstrando que tanto as CTMs isoladas de indivíduos saudáveis quanto de pacientes com doenças autoimunes inibiam a proliferação de linfócitos autólogos ou alogênicos de maneira dose-dependente e que essa inibição era independente da atividade clínica da doença (BOCELLI-TYNDALL et al., 2007).

Concluindo, observamos que as CTMs de pacientes são capazes de suprimir a proliferação de linfócitos de maneira dose-dependente. No entanto, as CTMs de pacientes possuem capacidade antiproliferativa reduzida em relação às CTMs de indivíduos saudáveis. Embasados nesses achados, podemos considerar que as CTMs isoladas de pacientes com EM não sejam as mais adequadas para terapias celulares autólogas em DAls.

\subsection{AVALIAÇÃO DAS SUBPOPULAÇÕES LINFOCITÁRIAS INDUZIDAS PELO COCULTIVO COM CÉLULAS ESTROMAIS MESENQUIMAIS}

Alguns trabalhos já haviam demonstrado o papel das CTMs no recrutamento e regulação das células T reguladoras (DI IANNI et al., 2008), bem como a capacidade de indução e proliferação de células $T$ reguladoras em cocultivos de CTMs com células mononucleares (ENGLISH et al., 2009; ENGLISH, 2013). No trabalho de English e colaboradores (2009), foi demonstrado que CTMs humanas isoladas da medula óssea induzem células Tregs pelo contato célula-célula, promovendo a expressão de Foxp3 e $\mathrm{CD}_{2} 5^{\mathrm{hi}}$ pelas células $\mathrm{T}$ CD4 ${ }^{+}$. Além disso, TGF- $\beta 1$ e PGE2 produzidos pelas CTMs 
desempenham papel fundamental na indução de células T CD $4^{+} \mathrm{CD} 25^{\mathrm{hi}} \mathrm{Foxp} 3^{+}$(ENGLISH et al., 2009).

As células $T$ reguladoras constituem subpopulação de células $T$ que suprime a ativação do sistema imune e assim auxiliam na manutenção da homeostasia e tolerância a antígenos próprios (UCCELLI et al., 2006). Sabe-se que as CTMs induzem a produção de IL-10 pelas células dendríticas plasmocitoides, que por sua vez, desencadeiam a geração de Tregs (UCCELLI et al., 2008). Além disso, foi demonstrado que o cocultivo de CTMs com linfócitos $\mathrm{T}$ antígeno-específicos induz diretamente a proliferação de Tregs através da liberação da molécula HLA-G5 solúvel (UCCELLI et al., 2008; DAZZI et al., 2012).

As moléculas de superfície CTLA-4 (cytotoxic T lymphocyte associated antigen-4) e GITR (glucocorticoid-induced T-cell receptor) são altamente expressas em células T reguladoras, assim como o CD25 (VON BOEHMER, 2005). O estudo de Aggarwal e Pittenger (2005) mostrou que as CTMs induziam a expressão de GITR em linfócitos T, que por sua vez, exerciam atividade supressora nas coculturas com células linfomononucleares. Outro estudo, de Prevosto e colaboradores (2007) mostrou que as CTMs também induziam a expressão de CTLA-4 em linfócitos T, também com atividade inibitória nas culturas.

Em nosso trabalho, detectamos células com o perfil $\mathrm{CD}^{+} \mathrm{CD} 25^{\mathrm{hi}} \mathrm{FOXP} 3^{+}$, CD $4^{+}$CD $25^{\text {hi }}$ CTLA $-4^{+}, \quad$ CD $4^{+} C D 25^{\text {hi }}$ ITRR $^{+}, \quad$ recuperadas após 0 cocultivo de linfomononucleares do sangue periférico com CTMs de indivíduos saudáveis e de pacientes pré- e pós-TACTH, no entanto, não observamos diferenças significantes nas percentagens dessas células entre os grupos avaliados, e também em relação aos controles (CMNs + PHA).

As células NKT são células T semelhantes a células NK (NK-like) que coexpressam marcadores de células NK (CD16 e CD56) e células T (CD3). Essas células são capazes de produzir citocinas imunossupressoras, como a IL-4, e por isso são consideradas células com potencial imunorregulador (KRONENBERG \& RUDENSKY, 2005; NOVAC \& LEHUEN, 2010). Em nosso estudo, foram detectadas essas células NKT reguladoras nos cocultivos com CTMs controle e de pacientes, embora sem diferenças significantes entre os grupos e, em relação aos controles CMNs + PHA. Não existem trabalhos na literatura avaliando essa populução celular em cocultivos com CTMs.

Algumas das propriedades imunorreguladoras das CTMs estão relacionadas com a liberação de HLA-G solúvel por essas células (FAINARD et al., 2011). Trabalhos demonstram que no sobrenadante de coculturas de CTMs com linfomononucleares encontram-se altos níveis de IL-10 e que esse efeito seja revertido com anticorpos anti-HLAG (SELMANI et al., 2007; RIZZO et al., 2008). Outro trabalho, de Selmani e colaboradores (2007), mostrou que a liberação de HLA-G5 por CTMs humanas é necessária para a inibição da proliferação de linfócitos, para supressão da citotoxicidade de células NK e para 
a indução de células T reguladoras $\mathrm{CD}^{+}{ }^{+} \mathrm{CD} 25^{\mathrm{hi}} \mathrm{FOXP3}^{+}$(SELMANI et al., 2007). Ademais, através de mecanismo denominado trogocitose, o HLA-G ancorado à membrana das CTMs pode ser transferido para outras células, como os linfócitos, promovendo inibição através do contato célula-célula (DAVIS, 2007). Em nosso trabalho, a molécula HLA-G foi detectada nas subpopulações de linfócitos $\mathrm{T} \mathrm{CD}^{+}$e $\mathrm{CD}^{+}$recuperadas após os experimentos de cocultivo com CTMs controles e de pacientes, sugerindo que a inibição observada contou com a participação de mecanismos dependentes de contato, além da liberação de fatores solúveis. No entanto, não foram observadas diferenças significantes entre os grupos de CTMs controle e de pacientes em relação aos controles (CMNs + PHA).

Concluindo, foram detectadas subpopulações linfocitárias com fenótipo regulador nas coculturas com CTMs isoladas de doadores saudáveis e de pacientes com EM pré- e pós-TACTH, no entanto, com porcentagens similares entre os grupos avaliados.

\subsection{PERFIL DE CITOCINAS NO SOBRENADANTE DAS COCULTURAS}

Vários estudos vêm demonstrando que a capacidade antiproliferativa e reguladora das CTMs é maior em ambiente inflamatório, ou seja, a presença de citocinas próinflamatórias induz as CTMs a produzir fatores responsáveis pela imunossupressão (UCCELLI et al., 2008; BASSI et al., 2012). A produção da IDO é acentuada em respostas inflamatórias e pode ser induzida por LPS e citocinas pró-inflamatórias, principalmente por IFN- $\gamma$ (BASSI et al., 2012). Nas CTMs, o eixo IFN- $\gamma /$ CTM é essencial na modulação da proliferação de linfócitos (ENGLISH et al., 2007; DELAROSA et al., 2009; BASSI et al., 2012). No trabalho de Suva e colaboradores (2007), o bloqueio do IFN- $\gamma$ em coculturas de CTMs e linfócitos promoveu restauração significativa da proliferação, indicando a participação desta citocina no licenciamento das CTMs para produzir fatores solúveis, responsáveis pela sua capacidade imunossupressora.

Além da indução da produção de IDO pelas CTMs, o trabalho de Ren e colaboradores (2008) mostrou que o IFN- $\gamma$ em combinação com outras citocinas próinflamatórias, como TNF e IL-1 , estimula as CTMs de camundongos a produzir quimiocinas e óxido nítrico sintase induzível (iNOS), que inibe a ativação de linfócitos $T$ através da produção de óxido nítrico (UCCELLI et al., 2008; REN et al., 2008). Além disso, foi demonstrado que o TNF e IFN- $\gamma$ aumentam a produção constitutiva de PGE2 pelas CTMs humanas pela indução de COX2 (AGGARWAL \& PITTENGER, 2005; UCCELLI et al., 2008).

O trabalho de Zafranskaya e colaboradores (2012) mostrou que os níveis de IFN- $\gamma$ diminuem significativamente no sobrenadante das coculturas com CTMs de pacientes com EM $(704,1[140,6-1267,8] \mathrm{pg} / \mathrm{ml})$ quando comparadas a células linfomononucleares estimuladas com PHA (1778,7 [499,0-1816,8] pg/ml). Em nosso trabalho, não encontramos 
diferenças nos níveis de IFN- $\gamma$ no sobrenadante das coculturas com CTMs de doadores saudáveis $(302 \pm 70,6 \mathrm{pg} / \mathrm{mL})$ e de pacientes pré-TACTH $(364 \pm 152 \mathrm{pg} / \mathrm{mL})$ e pós-TACTH $(557,5 \pm 160,6 \mathrm{pg} / \mathrm{mL})$. Além disso, não foram observadas diferenças significantes nos níveis de TNF e IL-1 $\beta$ nas coculturas com CTMs de indivíduos saudáveis ou de pacientes com EM (pré- e pós-TACTH).

A IL-6 está associada com respostas imunes antígeno-específicas e reação inflamatória pela indução da diferenciação de células T e produção de IL-2 (KISHIMOTO, 2010). As CTMs secretam altos níveis de IL-6 e podem inibir a diferenciação de células dendríticas por mecanismos dependentes de IL-6 (DJOUAD et al., 2007). Guo e colaboradores (2009) cultivaram CTMs isoladas da medula óssea fetal com células TCD4 ${ }^{+}$ humanas e observaram altos níveis de IL-6 e IL-1. Mazzanti e colaboradores (2008) relataram níveis similares de IL-6 no sobrenadante de coculturas de CTMs controle e de pacientes com EM, quando estimuladas com LPS. Da mesma forma, em nosso trabalho não observamos diferenças nos níveis de IL-6 no sobrenadante das coculturas com CTMs controle e de pacientes (pré- e pós-TACTH), estimuladas com PHA.

Alguns estudos in vitro, realizados em modelos animais, mostraram que linfócitos estimulados com aloantígenos na presença de CTMs produziam grandes quantidades de IL10 e que, quando a IL-10 ou seu receptor eram bloqueados ocorria reversão na inibição da proliferação induzida pela célula mesenquimal (RASMUSSON et al., 2005; YANG et al., 2009; BASSI et al., 2012). Outro dado interessante, quando essas células eram cocultivadas diretamente, a produção de IL-10 e TGF- $\beta$ era maior do que quando as células eram cocultivadas em transwell, sugerindo que o contato célula-célula é importante para a capacidade antiproliferativa e imunorreguladora das CTMs (NASEF et al., 2007; BASSI et al., 2012).

Em nosso estudo, encontramos que as concentrações de IL-10 e TGF- $\beta$ estavam significantemente diminuídas nos cocultivos com CTMs de pacientes (pré- e pós-TACTH) quando comparadas aos cocultivos com CTMs de doadores saudáveis, sugerindo que a secreção diminuída dessas citocinas anti-inflamatórias tenha papel na menor capacidade inibitória das CTMs isoladas de pacientes sobre a proliferação de linfócitos alogênicos, como observado em nossos resultados.

As CTMs secretam altos níveis de CCL2 e uma variedade de quimiocinas, como CCL3, CCL4, CCL5, CCL7, CCL20, CCL26, CX3CL1, CXCL5, CXCL8, CXCL2 e CXCL10 (IP-10) (MEIRELLES et al., 2009; BASSI et al., 2012). Essas quimiocinas têm como alvo monócitos, eosinófilos, neutrófilos, basófilos, células $T$ naive e de memória, células $B$, células NK, células dendríticas e progenitores hematopoéticos e endoteliais (BASSI et al., 2012). Com relação à quimiocina $C X C L 10$ ou IP-10, estudos anteriores de Mazzanti e 
colaboradores (2008) observaram maior concentração dessa quimiocina nos sobrenadantes de culturas com CTMs de pacientes com EM, estimuladas com LPS, em comparação as culturas com CTMs controle. Diferente do relato de Mazzanti e colaboradores (2008), em nossos ensaios, os níveis de CXCL-10 estavam semelhantes nas coculturas com CTMs controle e coculturas com CTMs de pacientes com EM pré- e pós-TACTH.

O HGF é secretado constitutivamente pelas CTMs e está relacionado com regeneração/reparo tecidual em vários tecidos pela ativação de cascatas de sinalização tirosina quinases. Em experimentos in vitro, CTMs autólogas ou alogênicas foram capazes de suprimir a proliferação de linfócitos $\mathrm{T} \mathrm{CD}^{+}$e $\mathrm{T} \mathrm{CD}^{+}$induzida por estímulo policlonal. Além disso, foi observado que essa inibição era dependente de HGF e TGF- $\beta$, uma vez que o bloqueio dessas duas moléculas foi capaz de restaurar a proliferação dos linfócitos (DI NICOLA et al., 2002; BASSI et al., 2012). Em nosso trabalho, não observamos diferenças significantes na concentração de HGF nos sobrenadantes das coculturas com CTMs controle e de pacientes com EM (pré- e pós-TACTH).

Com base nos estudos que demonstraram a capacidade imunomoduladora das CTMs e também nos trabalhos em EAE, que demostraram o potencial terapêutico dessas células na modulação da resposta autoimune e na melhora do escore clínico, as CTMs se transformaram em alvos para terapia celular em pacientes com EM. A utilização de CTMs derivadas da medula óssea vem sendo utilizada como fonte autóloga para tratamento de pacientes com EM (KARUSSIS et al., 2010; YAMOUT et al., 2010; CONNICK et al., 2012; UCCELLI et al., 2012; COHEN, 2013), no entanto não existiam dados na literatura indicando se estas células possuíam algum defeito genético ou funcional que pudessem interferir de alguma forma no resultado terapêutico.

Concluindo, as CTMs de pacientes apresentaram aparência senescente, diminuição da expressão de marcadores imunofenotípicos característicos e capacidade de inibição da proliferação de linfócitos alogênicos reduzida. Não observamos diferenças na secreção de citocinas pró-inflamatórias nas coculturas com CTMs de doadores saudáveis e de pacientes com EM pré- e pós-TACTH, porém, a secreção das citocinas anti-inflamatórias, IL-10 e TGF$\beta$, estava reduzida nos cocultivos com CTMs de pacientes. Ainda, as CTMs isoladas da medula óssea de pacientes com EM exibiram perfil de expressão gênica diferente em relação às células-tronco isoladas de indivíduos saudáveis. Embora a nossa casuística seja pequena, esses dados sugerem que as CTMs de doadores saudáveis para uso clínico possam ser mais adequadas do que aquelas obtidas de pacientes com EM. 
CONCLUSÕES 


\section{CONCLUSÕES}

As CTHs isoladas da medula óssea de pacientes com EM apresentaram perfil de expressão gênica diferente em relação às células-tronco isoladas da medula óssea de doadores saudáveis. As CTHs de pacientes exibiram alterações na expressão de genes pertencentes a vias de sinalização importantes para a manutenção da quiescência e do pool de CTHs na medula, e ainda, alterações em vias envolvidas com o direcionamento para diferenciação em linhagens linfoide ou mieloide.

As CTMs isoladas da medula óssea de pacientes com EM exibiram aparência senescente, diminuição da expressão de marcadores imunofenotípicos característicos, reduzida capacidade antiproliferativa e diminuição da secreção in vitro de citocinas antiinflamatórias, crucias para o seu efeito imunossupressor (TGF- $\beta$ e IL-10). No entanto, após o cocultivo de células linfomononucleares periféricas com CTMs de doadores saudáveis ou de pacientes com EM pré- e pós-TACTH, as frequências de diversas subpopulações de células com perfis de linfócitos reguladores foram semelhantes. Por outro lado, as CTMs de pacientes apresentaram perfil de expressão gênica diferente das CTMs de indivíduos saudáveis, com alterações na expressão de genes que codificam moléculas e vias de sinalização, relacionadas com processos de imunossupressão/imunorregulação das CTMs. Após o TACTH, o perfil de expressão gênica das CTMs de pacientes assemelhou-se mais ao perfil pré-TACTH do que ao perfil de hibridação de indivíduos saudáveis. Embora a nossa casuística seja pequena, esses resultados sugerem que as CTMs de doadores saudáveis possam ser mais adequadas do que aquelas de pacientes com EM para uso clínico em pacientes com EM. 
REFER $\hat{\mathcal{E}} \mathcal{N} C I \mathcal{A} S$ 


\section{REFERÊNCIAS}

ADAMS GB, CHABNER KT, ALLEY IR et al. Stem cell engraftment at the endosteal niche is specified by the calcium-sensing receptor. Nature. 2006;439(7076):599-603.

AGGARWAL S, PITTENGER MF. Human mesenchymal stem cells modulate allogeneic immune cell responses. Blood. 2005;105(4):1815-22.

ARTAVANIS-TSAKONAS S, RAND MD, LAKE RJ. Notch signalling: cell fate control and signal integration in development. Science. 1999;284(5415):770-6.

ASARI S, ITAKURA S, FERRERI $\mathrm{K}$ et al. Mesenchymal stem cells suppress B-cell terminal differentiation. Exp Hematol. 2009;37(5):604-15.

ASCHERIO A, MUNCH M. Epstein-Barr virus and multiple sclerosis. Epidemiology. 2000;11(2):220-4.

ASTER JC. Deregulated Notch signaling in acute T-cell lympgoblastic leukemia/lymphoma: new insights, questions, and opportunities. Int J Hematol. 2005;82(4):295-301.

AUGELLO A, TASSO R, NEGRINI SM et al. Bone marrow mesenchymal progenitor cells inhibit lymphocyte proliferation by activation of the programmed death 1 pathway. Eur $\mathrm{J}$ Immunol. 2005;35(5):1482-90.

AULETTA JJ, BARTHOLOMEW AM, MAZIARZ RT et al. The potential of mesenchymal stromal cells as a novel cellular therapy for multiple sclerosis. Immunotherapy.2012;4(5):529-47.

BAECHLER EC, BATLIWALLA FM, REED AM et al. Gene expression profiling in human autoimmunity. Immunol Rev. 2006;210:120-37.

BAI L, LENNON DP, EATON $\vee$ et al. Human bone marrow-derived mesenchymal stem cells induce Th2-polarized immune response and promote endogenous repair in animal models of multiple sclerosis. Glia. 2009;57(11):1192-203.

BAI L, LENNON DP, CAPLAN Al et al. Hepatocyte growth factor mediates mesenchymal stem cellinduced recovery in multiple sclerosis models. Nat Neurosci. 2012;15(6):862-70.

BALASA R, BAJKO Z, HUTANU A. Serum levels of IL-17A in patients with relapsing-remitting multiple sclerosis treated with interferon- $\beta$. Mult Scler. 2012; Dec 3.

BANG OY, LEE JS, LEE PH, LEE G. Autologous mesenchymal stem cell transplantation in stroke patients. Ann Neurol. 2005;57(6):874-82.

BARTHOLOMEW A, STURGEON C, SIATSKAS $M$ et al. Mesenchymal stem cells suppress lymphocyte proliferation in vitro and prolong skin graft survival in vivo. Exp Hematol. 2002;30(1):42-8.

BASSI EJ, ALMEIDA DC, MORAES-VIEIRA, PM, CÂMARA NOS. Exploring the role of soluble factors associated with immune regulatory properties of mesenchymal stem cells. Stem Cell Rev. 2012; $8(2): 329-42$.

BEN-AMI E, BERRIH-AKNIN S, MILLER A. Mesenchymal stem cells as an immunomodulatory therapeutic strategy for autoimmune diseases. Autoimmun Rev. 2011;10(7):410-5.

BEN-NUN A, COHEN IR. Experimental autoimmune encephalomyelitis (EAE) mediated by T cell lines: process of selection of lines and characterization of the cells. J Immunol. 1982;129(1):303-8.

BETTELLI E, OUKKA M, KUCHROO VK. T(H)-17 cells in the circle of immunity and autoimmunity. Nat Immunol. 2007;8(4):345-50.

BIANCO P. Bone and hematopoietic niche: a tale of two stem cells. Blood;117(20):5281-8. 
BIGAS A, ROBERT-MORENO A, ESPINOSA L. The notch pathway in the developing hematopoietic system. Int J Dev Biol. 2010;54(6-7):1175-88.

BIGAS A, ESPINOSA L. Hematopoietic stem cells: to be or Notch to be. Blood. 2012;119(14):3226-35.

BOCELLI-TYNDALL C, BRACCI L, SPAGNOLI G et al. Bone marrow mesenchymal stromal cells (BMMSCs) from healthy donors and auto-immune disease patients reduce the proliferation of autologousand allogeneic-stimulated lymphocytes in vitro. Rheumatology. 2007;46(3):403-8.

BOHGAKI T, ATSUMI T, KOIKE T. Autoimmune disease after autologous hematopoietic stem cell transplantation. Autoimmun Rev. 2008;7(3):198-203.

BORNER C. The Bcl-2 protein family: sensors and checkpoints for life-or-death decisions. Mol Immunol. 2003;39(11):615-47.

BOUILLET P, O'REILLY LA. CD95, Bim and T cell homeostasis. Nat Rev Immunol. 2009;9(7):514-9.

BOYLE AJ, SCHULMAN SP, HARE JM, OETTGEN P. Is stem cell therapy ready for patients? Stem Cell Therapy for Cardiac Repair. Ready for the Next Step. Circulation. 2006;114(4):339-52.

BOYUM A. Separation of blood leukocytes, granulocytes and lymphocytes. Tissue Antigens. 1974;4(4): 269-74.

BRÖKER LE, KRUYT FA, GIACONNE G. Cell death independent of caspases: a review. Clin Cancer Res. 2005;11(9):3155-62.

BRUM DG, BARREIRA AA, DOS SANTOS AC et al.. HLA-DRB association in neuromyelitis optica is different from that observed in multiple sclerosis. Mult Scler. 2010;16(1):21-9.

BUCKNER JH. Mechanisms of impaired regulation by CD4(+)CD25(+)FOXP3(+) regulatory $\mathrm{T}$ cells in human autoimmune diseases. Nat Rev Immunol. 2010;10(12):849-59.

BÜHRING HJ, BATTULA VL, TREML S, SCHEWE B, KANZ L, VOGEL W. Novel markers for the prospective isolation of human MSC. Ann N Y Acad Sci. 2007;1106:262-71.

BURR SP, DAZZI F, GARDEN OA. Mesenchymal stromal cells and regulatory T cells: the Yin and Yang of peripheral tolerance? Immunol Cell Biol. 2013;91(1):12-8.

BURT RK, SLAVIN S, BURNS WH, MARMONT AM. Induction of tolerance in autoimmune diseases by hematopoietic stem cell transplantation: getting closer to a cure? Blood. 2002;99(3):768-84.

BURT RK, TRAYNOR AE, CRAIG R, MARMONT AM. The promise of hematopoietic stem cell transplantation for autoimmune diseases. Bone Marrow Transplant. 2003;31(7):521-4.

BURT RK, COHEN B, ROSE J et al. Hematopoietic stem cell transplantation for multiple sclerosis. Arch Neurol. 2005;62(6):860-4.

BURT RK, TESTORI A, CRAIG R, COHEN B, SUFFIT R, BARR W. Hematopoietic stem cell transplantation for autoimmune diseases: What have we learned? J Autoimmun. 2008;30(3):116-20.

BURT RK, BALABANOV R, VOLTARELLI J, BARREIRA A, BURMAN J. Autologous hematopoietic stem cell transplantation for multiple sclerosis- if confused or hesitant, remember: 'treat with standard immune suppressive drugs and if no inflammation, no response'. Mult Scler. 2012;18(6):772-5.

CARPENTER AC, BOSSELUT R. Decision checkpoints in the thymus. Nat Immunol. 2010;11(8):66673.

CAVASSANI KA, ISHII M, WEN H et al. TLR3 is an endogenous sensor of tissue necrosis during acute inflammatory events. J Exp Med. 2008;205(11):2609-21. 
CHEN C, LIU Y, LIU R et al.TSC-mTOR maintains quiescence and function of hematopoietic stem cells by repressing mitochondrial biogenesis and reactive oxygen species. $J$ Exp Med. 2008;205(10):2397-408.

CHERVONSKY AV. Influence of microbial environment on autoimmunity. Nat Immunol. 2010;11(1):2835.

CHOMCZYNSKI P, SACCHI N. Single-step method of RNA isolation by acid guanidinium thiocyanatephenol-chloroform extraction. Anal Biochem. 1987;162(1):156-9.

CHUNG YJ, PARK BB, KANG YJ, KIM TM, EAVES CJ, OH IH. Unique effects of STAT3 on the early phase of hematopoietic stem cell regeneration. Blood. 2006;108(4):1208-15.

COHEN JA. Mesenchymal stem cell transplantation in multiple sclerosis. J Neurol Sci. 2013; Jan 4.

COMPSTON A, COLES A. Multiple sclerosis. Lancet. 2002;359(9313):1221-31.

CONNICK P, KOLAPPAN M, CRAWLEY $C$ et al. Autologous mesenchymal stem cells for the treatment of secondary progressive multiple sclerosis: an open-label phase 2a proof-of-concept study. Lancet Neurol. 2012;11(2):150-6.

COOKE A. Th17 cells in inflammatory conditions. Rev Diabet Stud. 2006;3(2):72-5.

CORCIONE A, BENVENUTO F, FERRETTI E et al. Human mesenchymal stem cells modulate B-cell functions. Blood. 2006;107(1):367-72.

COSTENBADER KH, GAY S, ALARCÓN-RIQUELME ME, LACCARINO L, DORIA A. Genes, epigenetic regulation and environmental factors: Which is the most relevant in developing autoimmune diseases? Autoimmun Rev. 2012;11(8):604-9.

COVAS DT, PANEPUCCI RA, FONTES AM et al. Multipotent mesenchymal stromal cells obtained from diverse human tissues share functional properties and gene-expression profile with CD146+ perivascular cells and fibroblasts. Exp Hematol. 2008;36(5):642-54.

CRISAN M, YAP S, CASTEILLA L al. A perivascular origin for mesenchymal stem cells in multiple human organs. Cell Stem Cell. 2008;3(3):301-13.

DA SILVA MEIRELLES L, CAPLAN AI, NARDI NB. In Search of the in vivo identity of mesenchymal stem cells. Stem Cells. 2008;26(9):2287-99.

DAZZI F, RAMASAMY R, GLENNIE S, JONES SP, ROBERTS I. The role of mesenchymal stem cells in haemopoiesis. Blood Rev. 2006;20(3):161-71.

DAZZI F, VAN LAAR JM, COPE A, TYNDALL A. Cell therapy for autoimmune diseases. Arthritis Res Ther. 2007;9(2):206.

DAZZI F, MARELLI-BERG FM. Mesenchymal stem cells for graft-versus-host disease: Close encounters with T cells. Eur J Immunol. 2008;38(6):1479-82.

DAZZI F, KRAMPERA M. Mesenchymal stem cells and autoimmune diseases. Best Pract Res Clin Haematol. 2011;24(1):49-57.

DAZZI F, LOPES L, WENG L. Mesenchymal stromal cells: a key player in 'innate tolerance'? Immunology. 2012;137(3):206-13.

DAVIS DM. Intercellular transfer of cell-surface proteins is common and can affect many stages of an immune response. Nat Rev Immunol. 2007;7(3):238-43.

DE MIGUEL MP, FUENTES-JULIÁN S, BLÁZQUEZ-MARTÍNEZ A et al. Immunosuppressive properties of mesenchymal stem cells: advances and applications. Curr Mol Med. 2012;12(5):574-91. 
DELAROSA O, LOMBARDO, O, BERAZA A et al. Requirement of IFN-gamma-mediated indoleamine 2,3-dioxygenase expression in the modulation of lymphocyte proliferation by human adipose-derived mesenchymal stem cells. Tissue Eng Part A. 2009;15(10):2795-806.

DENG W, HAN Q, LIAO L, YOU S, DENG H, ZHAO RC. Effects of allogeneic bone marrow-derived mesenchymal stem cells on T and B lymphocytes from BXSB mice. DNA Cell Biol. 2005;24(7):458-63.

DI IANNI M, DEL PAPA B, DE IOANNI M et al. Mesenchymal cells recruit and regulate T regulatory cells. Exp Hematol. 2008;36(3):309-18.

DI NICOLA M, CARLO-STELLA C, MAGNI M et al. Human bone marrow stromal cells suppress Tlymphocyte proliferation induced by cellular or nonspecific mitogenic stimuli. Blood. 2002;99(10):383843.

DIAZ-BLANCO E, BRUNS I, NEUMANN F et al. Molecular signature of CD34(+) hematopoietic stem and progenitor cells of patients with CML in chronic phase. Leukemia. 2007;21(3):494-504.

DJOUAD F, CHARBONNIER LM, BOUFFI C et al. Mesenchymal stem cells inhibit the differentiation of dendritic cells through an interleukin-6-dependent mechanism. Stem cells. 2007;25(8):2025-32.

DOMENICK MA, ILDSTAD ST. Impact of bone marrow transplantation on type I diabetes. World $J$ Surg. 2001;25(4):474-80.

DOMINICI M, LE BLANC K, MUELLER I et al. Minimal criteria for defining multipotent mesenchymal stromal cells. The International Society for Cellular Therapy position statement. Cytotherapy. 2006;8(4):315-7.

DUFFY MM, PINDJAKOVA J, HANLEY SA. Mesenchymal stem cell inhibition of T-helper 17 differentiation is triggered by cell-cell contact and mediated by prostaglandin E2 via EP4 receptor. Eur J Immunol. 2011;41(10):2840-51.

EHNINGER A, TRUMPP A. The bone marrow stem cell niche grows up: mesenchymal stem cells and macrophages. J Exp Med. 2011;208(3):421-8.

ENGLISH K, BARRY FP, FIELD-CORBETT CP, MAHON BP. IFN-gamma and TNF-alpha differentially regulate immunomodulation by murine mesenchymal stem cells. Immunol Lett. 2007;110(2):91-100.

ENGLISH K, RYAN JM, TOBIN L, MURPHY MJ, BARRY FP, MAHON BP. Cell contact, prostaglandin $E(2)$ and transforming growth factor beta 1 play non-redundant roles in human mesenchymal stem cell induction of $\mathrm{CD} 4+\mathrm{CD} 25$ (high) forkhead box $\mathrm{P} 3+$ regulatory $\mathrm{T}$ cells. Clin Exp Immunol. 2009;156(1):149-60.

ENGLISH K. Mechanisms of mesenchymal stromal cell immunomodulation. Immunol Cell Biol. 2013;91(1):19-26.

ERMANN J, FATHMAN CG. Autoimmune diseases: genes, bugs and failed regulation. Nat Immunol. 2001;2(9):759-61.

FAINARDI E, CASTELLAZZI M, STIGNANI M et al. Emerging topics and new perspectives on HLA-G. Cell Mol Life Sci. 2011;68(3):433-51.

FÄNDRICH F, ZHOU X, SCHLEMMINGER M, LIN X, DRESSKE B. Future strategies for tolerance induction: a comparative study between hematopoietic stem cells and macrophages. Hum Immunol. 2002;63(10):805-12.

FARIAS KCRM. Avaliação da reconstituição imunológica em pacientes com diabete melito do tipo $1 \mathrm{e}$ esclerose múltipla após transplante autólogo de células tronco hematopoéticas. 2006. 286f. Tese de Doutorado- Faculdade de Medicina de Ribeirão Preto, Universidade de São Paulo, Ribeirão Preto, 2006. 
FARRÉ J, ROURA S, PRAT-VIDAL C et al. FGF-4 increases in vitro expansion rate of human adult bone marrow-derived mesenchymal stem cells. Growth Factors. 2007;25:71-76.

FLEMING HE, JANZEN V, LO CELSO $\mathrm{C}$ et al. Wht signaling in the niche enforces hematopoietic stem cell quiescence and is necessary to preserve self-renewal in vivo. Cell Stem Cell. 2008;2(3):274-83.

FOSTER JG, BLUNT MD, CARTER E, WARD SG. Inhibition of PI3K Signaling Spurs New Therapeutic Opportunities in Inflammatory/Autoimmune Diseases and Hematological Malignancies. Pharmacol Rev. 2012;64(4):1027-54.

FRANÇOIS M, ROMIEU-MOUREZ R, LI M, GALIPEAU J. Human MSC suppression correlates with cytokine induction of indoleamine 2,3-oxygenase and bystander M2 macrophage, Mol Ther. 2012;20(1):187-95.

FRIC J, LIM CX, KOH EG et al. Calcineurin/NFAT signalling inhibits myeloid haematopoiesis. EMBO Mol Med. 2012;4(4):269-82.

GAMPER CJ, POWELL JD. All PI3Kinase signaling is not mTOR: dissecting mTOR-dependent and independent signaling pathways in T cells. Front Immunol. 2012;3:312.

GEORGANTAS RW 3RD, TANADVE V, MALEHORN M et al. Microarray and serial analysis of gene expression analyses identify known and novel transcripts overexpressed in hematopoietic stem cells. Cancer Res. 2004; 64(13): 4434-41.

GERDONI E, GALLO B, CASAZZA S et al. Mesenchymal stem cells effectively modulate pathogenic immune response in experimental autoimmune encephalomyelitis. Ann Neurol. 2007;61(3):219-27.

GHANNAM S, PĖNE J, TORCY-MOQUET G, JORGENSEN C, YSSEL H. Mesenchymal stem cell inhibit human Th17 cell differentiation and function and induce a $T$ regulatory cell phenotype. $J$ immunol. 2010;185(1):302-12.

GIESEKE F, BÖHRINGER J, BUSSOLARI R, DOMINICI M, HANDGRETINGER R, MÜLLER I. Human multipotent mesenchymal stromal cells use galectin-1 to inhibit immune effector cells. Blood. 2010;116(19):3770-9.

GLENNIE S, SOEIRO I, DYSON PJ, LAM EW, DAZZI F. Bone marrow mesenchymal stem cells induce division arrest anergy of activated T cells. Blood. 2005;105(7):2821-7.

GREENSTEIN JI. Current concepts of the cellular and molecular pathophysiology of multiple sclerosis. Dev Neurobiol. 2007;67(9):1248-65.

GONZÁLEZ-GARCÍA S, GARCÍA-PEYDRÓ M, MARTÍN-GAYO E et al. CSL-MAML-dependent Notch1 signaling controls T lineage-specific IL-7Ralpha gene expression in early human thymopoiesis and leukemia. J Exp Med. 2009;206(4):779-791.

GOODNOW CC, SPRENT J, FAZEKAS DE ST GROTH B, VINUESA CG. Cellular and genetic mechanisms of self tolerance and autoimmunity. Nature. 2005;435(7042):590-7.

GOSSELIN D, RIVEST S. Immune mechanisms underlying the beneficial effects of autologous hematopoietic stem cell transplantation in multiple sclerosis. Neurotherapeutics. 2011;8(4):643-9.

GOVERMAN J. Autoimmune T cell responses in the central nervous system. Nat Rev Immunol. 2009;9(6):393-407.

GROH ME, MAITRA B, SZEKELY E, KOÇ ON. Human mesenchymal stem cells require monocytemediated activation to suppress alloreactive T cells. Exp Hematol. 2005;33(8):928-34.

GRONSKI M, WEINEM M. Death pathways in T cell homeostasis and their role in autoimmune diabetes. Rev Diabet Stud. 2006;3(2):88-95. 
GUELLER S, KOMOR M, NOWAK D et al.Identification of defects in the transcriptional program during lineage-specific in vitro differentiation of CD34(+)cells selected from patients with both low- and highrisk myelodysplastic syndrome. Exp Hematol. 2010; 38(9):718-32.

GUO Z, ZHENG C, CHEN Z et al. Fetal BM-derived mesenchymal stem cells promote the expansion of human Th17 cells, but inhibit the production of Th1 cells. Eur J Immunol. 2009;39(10):2840-9.

GUSTAFSSON AB, GOTTLIEB RA. Bcl-2 family members and apoptosis, taken to heart. Am J Physiol Cell Physiol. 2007;292(1):C45-51.

HAAS J, HUG A, VIEHÖVER A et al. Reduced suppressive effect of CD4+CD25high regulatory T cells on the $T$ cell immune response against myelin oligodendrocyte glycoprotein in patients with multiple sclerosis. Eur J Immunol. 2005;35(11):3343-52.

HAFLER DA. Multiple sclerosis. J Clin Invest. 2004;113(6):788-94.

HAFLER DA et al. Risk alleles for multiple sclerosis identified by a genomewide study. $N$ Engl $J$ Med. 2007;357(9):851-62.

HAYASHI T, FAUSTMAN DL. Implications of altered apoptosis in diabetes mellitus and autoimmune disease. Apoptosis. 2001;6(1-2):31-45.

HEBB AL, MOORE CS, BHAN V et al. Expresssion of the inhibitor of apoptosis protein family in multiple sclerosis reveals a potential immunomodulatory role during autoimmune mediated demyelination. Mult Scler. 2008;14(5):577-94.

HEMMER B, ARCHELOS JJ, HARTUNG HP. New concepts in the immunopathogenesis of multiple sclerosis. Nat Rev Neurosci. 2002;3(4):291-301.

HERZ J, ZIPP F, SIFFRIN V. Neurodegeneration in autoimmune CNS inflammation. Exp Neurol. 2010;225(1):9-17.

HOHLFELD R, WEKERLE H. Autoimmune concepts of multiple sclerosis as a basis for selective immunotherapy: from pipe dreams to (therapeutic) pipelines. Proc Natl Acad Sci USA. 2004; 101(Suppl 2):14599-606.

HORWITZ EM, GORDON PL, KOO WK et al. Isolated allogeneic bone marrow-derived mesenchymal cells engraft and stimulate growth in children with osteogenesis imperfecta: implications for cell therapy of bone. Proc Natl Acad Sci USA. 2002;99(13):8932-7.

HORWITZ EM, LE BLANC K, DOMINICI M et al. Clarification of the nomenclature for MSC: The International Society for Cellular Therapy position statement. Cytotherapy. 2005;7(5):393-5.

HOUGH RE, SNOWDEN JA, WULFFRAAT NM. Haematopoietic stem cell transplantation in autoimmune diseases: a European perspective. Br J Haematol. 2005;128(4):432-59.

HUAN J, CULBERTSON N, SPENCER L et al. Decreased FOXP3 levels in multiple sclerosis patients. J Neurosci Res. 2005;81(1):45-52.

HUANG DW, SHERMAN BT, LEMPICKI RA. Systematic and integrative analysis of large gene lists using DAVID bioinformatics resources. Nat protoc. 2009;4(1):44-57.

HUANG X, CHO S, SPANGRUDE GJ. Hematopoietic stem cells: generation and self renewal. Cell Death Differ. 2007;14(11):1851-9.

HUGHES P, BOUILLET P, STRASSER A. Role of Bim and other Bcl-2 members in autoimmune and degenerative diseases. Curr Dir Autoimmmun. 2006;9:74-94.

HWA CHO H, BAE YC, JUNG JS. Role of toll-like receptors on human adipose-derived stromal cells. Stem Cells. 2006;24(12):2744-52. 
IKEHARA S, KAWAMURA M, TAKAO $\mathrm{F}$ et al. Organ-specific and systemic autoimmune diseases originate from defects in hematopoietic stem cells. Proc Natl Acad Sci USA. 1990;87(21):8341-4.

IKEHARA S, INABA M, YASUMIZU R et al. Autoimmune diseases as stem cell disorders. Tohoku $\mathrm{J}$ Exp Med. 1994;173(1):141-55.

IKEHARA S. Autoimmune diseases as stem cells disorders: normal stem cell transplant for their treatment. Int J Molec Med. 1998;1(1):5-16.

IKEHARA S. A new concept of stem cell disorders and their new therapy. $J$ Hematother Stem Cell Res. 2003;12(6):643-53.

IKEHARA S. A novel method of bone marrow transplantation (BMT) for intractable autoimmune diseases. J Autoimmun. 2008;30(3):108-15.

INOKI K, CORRADETTI MN, GUAN KL. Dysregulation of the TSCmTOR pathway in human disease. Nat Genet. 2005;37(1):19-24.

IRANI DN. Immunological mechanisms in multiple sclerosis. Clin Appl Immunol Rev. 2005;5(4):25769.

ITO T, SAWADA R, FUJIWARA Y, TSUCHIYA T. FGF-2 increases osteogenic and chondrogenic differentiation potencials of human mesenchymal stem cells by inactivation of TGF-beta signaling. Cytotechnology. 2008;56(1):1-7.

KALAITZIDIS D, SYKES SM, WANG Z et al. mTOR complex 1 plays critical roles in hematopoiesis and Pten-loss-evoked leukemogenesis. Cell Stem Cell. 2012;11(3):429-39.

KALWITZ G, ENDRES M, NEUMANN K et al. Gene expression profile of adult human bone marrowderived mesenchymal stem cells stimulated by the chemokine CXCL7. Int J Biochem Cell Biol. 2009; 41(3):649-58

KAMRADT T, MITCHISON NA. Review: Tolerance and autoimmunity. $N$ Engl $J$ Med. 2001;344(9):655-64.

KASSIS I, GRIGORIADIS N, GOWDA-KURKALLI B et al. Neuroprotection and immunomodulation with mesenchymal stem cells in chronic experimental autoimmune encephalomyelitis. Arch Neurol. 2008;65(6):753-61.

KARUSSIS D, KARAGEORGIOU C, VAKNIN-DEMBINSKY A et al. Safety and immunological effects of mesenchymal stem cell transplantation in patients with multiple sclerosis and amyotrophic lateral sclerosis. Arch Neurol. 2010; 67(10):1187-94.

KARUSSIS D. Worldwide status of clinical experimentation with stem cells in neurologic diseases. Neurology. 2012;78(17):1334-6.

KATO Y, IWAMA A, TADOKORO $Y$ et al. Selective activation of STAT5 unveils its role in stem cell self-renewal in normal and leukemic hematopoiesis. J Exp Med. 2005;202(1):169-79.

KAWAKAMI A, EGUCHI K. Involvement of apoptotic cell death in autoimmune diseases. Med Electron Microsc. 2002;35(1):1-8.

KERN S, EICHLER H, STOEVE J, KLÜTER H, BIEBACK K. Comparative analysis of mesenchymal stem cells from bone marrow, umbilical cord blood, or adipose tissue. Stem Cells. 2006;24(5):1294301.

KIKLY K, LIU L, NA S, SEDGWICK JD. The IL-23/TH(17) axis: therapeutic targets for autoimmune inflammation. Curr Opin Immunol. 2006;18(6):670-5. 
KING KY, GOODELL MA. Inflammatory modulation of HSCs: viewing the HSC as a foundation for the immune response. 2011;11(10):685-92.

KISHIMOTO T. IL-6: from its discovery to clinical applications. Int Immunol. 2010;22(5):347-52.

KLINAKIS A, LOBRY C, ABDEL-WANAB $O$ et al. A novel tumor-supressor function for the Notch pathway in myeloid leukaemia. Nature. 2011; 473(7346):230-3.

KOKOLUS K, NEMETH MJ. Non-canonical Wnt signaling pathways in hematopoiesis. Immunol Res. 2010;46(1-3):155-64.

KONDO M, WAGERS AJ, MANZ MG et al. Biology of hematopoietic stem cells and progenitors: implications for clinical application. Annu Rev Immunol. 2003;21:759-806.

KÖTTER I, DAIKELER T, EINSELE H et al. Relapse of autoimmune diseases after autologous $T$ cell depleted stem cell transplantation may be triggered by $\mathrm{T}$ cells recently emigrated from the thymus. Ann Rheum Dis. 2005;64(12):1787-9.

KRAMPERA M, GLENNIE S, DYSON $J$ et al. Bone marrow mesenchymal stem cells inhibit the response of naive and memory antigen-specific T cells to their cognate peptide. Blood. 2003; 101(9): $3722-9$.

KRATCHMAROVA I, BLAGOEV B, HAACK-SORENSEN M, KASSEM M, MANN M. Mechanism of divergent growth factors effects in mesenchymal stem cell differentiation. Science. 2005;308(5727):1472-7.

KRONENBERG M, RUDENSKY A. Regulation of immunity by self-reactive $T$ cells. Nature. 2005;435(7042):598-604.

KUHTREIBER WM, HAYASHI T, DALE EA, FAUSTMAN DI. Central role of defective apoptosis in autoimmunity. J Mol Endocrinol. 2003;31(3):373-99.

KULTERER B, FRIEDL G, JANDROSITZ A et al. Gene expression profiling of human mesenchymal stem cell derived from bone marrow during expansion and osteoblast differentiation. BMC Genomics. 2007;8:70.

KUMAR M, PUTZKI N, LIMMROTH V et al. CD4+CD25+FoxP3+ T lymphocytes fail to suppress myelin basic protein-induced proliferation in patients with multiple sclerosis. J Neuroimmunol. 2006;180(1-2):178-84.

LAAKSONEN M, PASTINEN T, SJÖROOS $M$ et al. HLA class II associated risk and protection against multiple sclerosis -a Finnish family study. J Neuroimmunol. 2002;122(1-2):140-5.

LAM BS, CUNNINGHAM C, ADAMS GB. Pharmacologic modulation of the calcium-sensing receptor enhances hematopoietic stem cell lodgement in the adult bone marrow. Blood. 2011;117(4):1167-75.

LARGHERO J, FARGE D, BRACCINI A et al. Phenotypical and functional characteristics of in vitro expanded bone marrow mesenchymal stem cells from systemic sclerosis patients. Ann Rheum Dis. 2008;67(4):443-9.

LASSMANN H. Pathophysiology of inflammation and tissue injury in multiple sclerosis: what are the targets for therapy. J Neurol Sci. 2011;306(1-2):167-9.

LAWSON JM, TREMBLE J, DAYAN $C$ et al. Increased resistance to CD4+CD25hi regulatory T cell-mediated suppression in patients with type 1 diabetes. Clin Exp Immunol. 2008;154(3):353-9.

LE BLANC K, TAMMIK L, SUNDBERG B, HAYNESWORTH SE, RINGDÉN O. Mesenchymal stem cells inhibit and stimulate mixed lymphocyte cultures and mitogenic responses independently of the major histocompatibility complex. Scand J Immunol. 2003;57(1):11-20. 
LE BLANC K, RASMUSSON I, SUNDBERG B et al. Treatment of severe acute graft-versus-host disease with third party haploidentical mesenchymal stem cells. Lancet. 2004;363(9419):1439-41.

LE BLANC K, RINGDÉN O. Immunobiology of human mesenchymal stem cells and future use in hematopoietic stem cell transplantation. Biol Blood Marrow Transplant. 2005;11(5):321-34.

LE BLANC K, PITTENGER MF. Mesenchymal stem cells: progress toward promise. Cytotherapy. 2005;7(1):36-45.

LE BLANC K, FRASSONI F, BALL L et al. Mesenchymal stem cells for treatment of steroid-resistant, severe, acute graft-versus-host disease: a phase II study. Lancet. 2008;371(9624):1579-86.

LE BLANC K, MOUGIAKAKOS D. Multipotent mesenchymal stromal cells and the innate immune system.

Nat Rev Immunol. 2012;12(5):383-96.

LEE JY, NAKADA D, YILMAZ OH et al. mTOR activation induces tumor suppressors that inhibit leukemogenesis and deplete hematopoietic stem cells after Pten deletion. Cell Stem Cell. 2010;7(5):593-605.

LEE K, NAM KT, CHO SH et al. Vital roles of mTOR complex 2 in Notch-driven thymocyte differentiation and leukemia. J Exp Med. 2012;209(4):713-28.

LIANG J, ZHANG H, HUA B et al. Allogeneic mesenchymal stem cells transplantation in treatment of multiple sclerosis. Mult Scler. 2009;15(5):644-6.

LIPHAUS BL, KISS MHB, CARRASCO S, GOLDENSTEIN-SCHAINBERG C. Increased Fas and Bcl-2 expression on peripheral blood $T$ and $B$ lymphocytes from juvenile-onset systemic lupus erythematosus, but not from juvenile rheumatoid arthrits and juvenile dermatomyositis. Clin Dev Immunol. 2006;13(2-4):283-7.

LIPHAUS BL, KISS MHB, CARRASCO S, GOLDENSTEIN-SCHAINBERG C. Increased Fas and Bcl-2 expression on peripheral mononuclear cells from patients with active juvenile-onset systemic lupus erythematosus. J Rheumatol. 2007;34(7):1580-4.

LIU H, POPE RM. The role of apoptosis in rheumatoid arthritis. Curr Opin Pharmacol. 2003;3(3):31722.

LIU H, HUANG Q, SHI B, EKSARKO P, TEMKIN V, POPE RM. Regulation of Mcl-1 expression in rheumatoid arthritis synovial macrophages. Arthritis e Rheumatism. 2007;54(10):3174-81.

LIU J, SATO C, CERLETTI M, WAGERS A. Notch signaling in the regulation of stem cell self-renewal and differentiation. Curr Top Dev Biol. 2010;92: 367-409.

LIU JW, DUNOYYER-GEINDRE S, SERRE-BEINIER V et al. Characterization of endothelial-like cells derived from human mesenchymal stem cells. J Thromb Haemost. 2007;5(4):826-34.

LIU SP, FU RH, HUANG SJ et al. Stem Cell Applications in Regenerative Medicine for Neurological Disorders. Cell Transplant. 2012;Oct 31.

LIU ZJ, ZHUGE Y, VELASQUEZ OC. Trafficking and differentiation of mesenchymal stem cells. $J$ Cell Biochem. 2009;106:984-91.

LOCK C, HERMANS G, PEDOTTI R et al. Gene-microarray analysis of multiple sclerosis lesions yields new targets validated in autoimmune encephalomyelitis. Nat Med. 2002;8(5):500-8.

LONG SA, CEROSALETTI K, BOLLYKY PL et al. Defects in IL-2R signaling contribute to diminished maintenance of FOXP3 expression in CD4+CD25+ regulatory $T$ cells of type 1 diabetic subjects. Diabetes. 2010;59(2):407-15. 
LUBLIN FD, REINGOLD SC. Defining the clinical course of multiple sclerosis: results of an international survey. National Multiple Sclerosis Society (USA) Advisory Committee on Clinical Trials of New Agents in Multiple Sclerosis. Neurology. 1996;46(4):907-11.

LUIS TC, WEERKAMP F, NABER BA et al. Wnt3a deficiency irreversibly impairs hematopoietic stem cell self-renewal and leads to defects in progenitor cell differentiation. Blood. 2009;113(3):546-54.

LUIS TC, NABER BA, FIBBE WE, VAN DONGEN JJ, STAAL FJ. Wnt3a nonredundantly controls hematopoietic stem cell function and its deficiency results in complete absence of canonical Wnt signaling. Blood. 2010;116(3):496-7.

LUTTEROTTI A, JELCIĆ I, SCHULZE C et al. No proinflammatory signature in CD34+ hematopoietic progenitor cells in multiple sclerosis patients. Mult Scler. 2012;18(8):1188-92.

LUTTON JD, WINSTON R, RODMAN TC. Multiple Sclerosis: etiological mechanisms and future directions. Exp Biol Med. 2004;229(1):12-20.

MAAS K, CHAN S, PARKER $J$ et al. Cutting edge: Molecular portrait of human autoimmune disease. $J$ Immunol. 2002;169(1):5-9.

MACCARIO R, PODESTÀ M, MORETTA A et al. Interaction of human mesenchymal stem cells with cells involved in alloantigen-specific immune response favors the differentiation of CD4+ T-cell subsets expressing a regulatory/suppressive phenotype. Haematologica. 2005;90(4):516-25.

MACKAY IR, LESKOVSEK NV, ROSE NR. Cell damage and autoimmunity: a critical appraisal. $J$ Autoimmun. 2008;30(1-2):5-11.

MAGEE JA, IKENOUE T, NAKADA D, LEE JY, GUAN KL, MORRISON SJ. Temporal changes in PTEN and mTORC2 regulation of hematopoietic stem cell self-renewal and leukemia suppression. Cell Stem Cell. 2012;11(3):415-28.

MAGGINI J, MIRKIN G, BOGNANNI I et al. Mouse bone-marrow-derived mesecnhymal stromal cells turn activated macrophages into a regulatory-like profile. Plos One. 2010;5(2):e9252.

MANCARDI GL, SORMANI MP, DI GIOIA M et al. Autologous haematopoietic stem cell transplantation with an intermediate intensity conditioning regimen in multiple sclerosis: the Italian multi-centre experience. Mult Scler. 2012;18(6):835-42.

MARIGO I, DAZZI F. The immunomodulatory properties of mesenchymal stem cells. Semin Immunopathol. 2011;33(6):593-602.

MARRACK P, KAPPLER J, KOTZIN BL. Autoimmune disease: why and where it occurs. Nat Med. 2001; 7(8):899-905.

MARYANOVICH M, OBERKOVITZ G, NIV H et al. The ATM-BID pathway regulates quiescence and survival of haematopoietic stem cells. Nat Cell Biol. 2012;14(5):535-41.

MATHIS D, BENOIST C. Levees of immunological tolerance. Nat Immunol. 2010;11(1):3-6.

MATSUDA C, TAKAGI M, HATTORI T, WAKITANI S, YOSHIDA T. Differentiation of human bone marrow mesenchymal stem cells to chondrocytes for construction of three-dimensional cartilage tissue. Cytotechnology. 2005;47(1-3):11-7.

MATUSEVICIUS D, KIVISÄKK P, HE B et al. Interleukin-17 mRNA expression in blood and CSF mononuclear cells is augmented in multiple sclerosis. Mult Scler. 1999;5(2):101-4.

MAZZANTI B, ALDINUCCI A, BIAGIOLI T et al. Differences in mesenchymal stem cell cytokine profiles between MS patients and healthy donors: implication for assessment of disease activity and treatment. J Neuroimmunol. 2008;199(1-2)142-50. 
MAZZINI L, MARESCHI K, FERRERO I, et al. Stem cell treatment in amyotrophic lateral sclerosis. $J$ Neurol Sci. 2008;265(1-2):78-83.

MAZZINI L, FERRERO I, LUPARELLO V, et al. Mesenchymal stem cell transplantation in amyotrophic lateral sclerosis: a phase I clinical trial. Exp Neurol. 2010;223(1):229-37.

MEIRELLES LDA S, FONTES AM, COVAS DT, CAPLAN Al. Mechanisms involved in the therapeutic properties of mesenchymal stem cells. Cytokine Growth Factor Rev. 2009;20(5-6):419-27.

MENSSEN A, HÄUPL T, SITTINGER M, DELORME B, CHARBORD P, RINGE J. Differential gene expression profiling of human bone marrow-derived mesenchymal stem cells during adipogenic development. BMC Genomics. 2011;12:461.

MERCIER FE, RAGU C, SCADDEN DT. The bone marrow at the crossroads of blood and immunity. Nat Rev Immunol. 2012;12(1):49-60.

MIKELS AJ, NUSSE R. Purified Wnt5a protein activates or inhibits beta-catenin-TCF signaling depending on receptor context. PLoS Biol. 2006;4(4):e115.

MORANDO S, VIGO T, ESPOSITO $\mathrm{M}$ et al. The therapeutic effect of mesenchymal stem cell transplantation in experimental autoimmune encephalomyelitis is mediated by peripheral and central mechanisms. Stem Cell Res Ther. 2012;3(1):3.

MUELLER DL. Mechanisms maintaining peripheral tolerance. Nat Immunol. 2010;11(1):21-7.

MÜLLAUER L, GRUBER P, SEBINGER D, BUCH J, WOHLFART S, CHOTT A. Mutations in apoptosis genes: a pathogenic factor for human disease. Mutat Res. 2001;488(3):211-31.

MÜLLER MR, SASAKI Y, STEVANOVIC I et al. Requirement for balanced Ca/NFAT signaling in hematopoietic and embryonic development. Proc Natl Acad Sci USA. 2009;106(17):7034-9.

MURARO PA, MARTIN R. Immunological questions on hematopoietic stem cell transplantation for multiple sclerosis. Bone Marrow Transplant. 2003;32 Suppl 1:S41-4.

MURARO PA, DOUEK DC, PACKER A et al. Thymic output generates a new and diverse TCR repertoire after autologous stem cell transplantation in multiple sclerosis patients. $J$ Exp Med. 2005;201(5):805-16.

MURARO PA, DOUEK DC. Renewing the T cell repertoire to arrest autoimmune aggression. Trends Immunol. 2006;27(2):61-7.

NAJAR M, RAICEVIC G, ID BOUFKER $\mathrm{H}$ et al. Modulated expression of adhesion molecules and galectin-1: role during mesenchymal stromal cell immunoregulatory functions. Exp Hematol. 2010;38(10):922-32.

NASEF A, CHAPEL A, MAZURIER C et al. Identification of IL-10 and TGF-beta transcripts involved in the inhibition of T-lymphocyte proliferation during cell contact with human mesenchymal stem cells. Gene Expr. 2007;13(4-5):217-26.

NASEF A, MAZURIER C, BOUCHET S et al. Leukemia inhibitory factor: role in human mesenchymal stem cells mediated immunosuppression. Cell Immunol. 2008;253(1-2):16-22.

NAUTA AJ, WESTERHUIS G, KRUISSELBRINK AB, LURVINK EG, WILLEMZE R, FIBBE WE. Donor-derived mesenchymal stem cells are immunogenic in an allogeneic host and stimulate donor graft rejection in a nonmyeloablative setting. Blood. 2006;108(6):2114-20.

NAUTA AJ, FIBBE WE. Immunomodulatory properties of mesenchymal stromal cells. Blood. 2007;110(10):3499-506. 
NEMETH MJ, TOPOL L, ANDERSON SM, YANG Y, BODINE DM. Wnt5a inhibits canonical Wnt signaling in hematopoietic stem cells and enhances repopulation. Proc Natl Acad Sci USA. 2007;104(39):15436-41.

NOVAK J, LEHUEN A. Mechanism of regulation of autoimmunity by iNKT cells. Cytokine. 2011;53(3):263-70.

NUSSINOVITCH U, SHOENFELD Y. The role of gender and organ specific autoimmunity. Autoimmun Rev. 2012;11(6-7):A377-85.

NYLANDER A, HAFLER DA. Multiple sclerosis. J Clin Invest. 2012;122(4):1180-8.

OHASHI PS. Negative selection and autoimmunity. Curr Opin Immunol. 2003;15(6):668-76.

OPFERMAN JT, KORSMEYER SJ. Apoptosis in the development and maintenance of the immune system. Nat Immunol. 2003;4(5):410-5.

OPFERMAN JT. Apoptosis in the development of the immune system. Cell Death Differ. 2008;15(2):234-42.

ORKIN SH, ZON LI. Hematopoiesis: an evolving paradigm for stem cell biology. Cell. 2008;132(4):631-44.

ORTIZ LA, DUTREIL M, FATTMAN $C$ et al. Interleukin 1 receptor antagonist mediates the antiinflammatory and antifibrotic effect of mesenchymal stem cells during lung injury. Proc Natl Acad Sci USA. 2007;104(26):11002-7.

OWENS GP, GILDEN D, BURGOON MP, YU X, BENNETT JL. Viruses and multiple sclerosis. Neuroscientist. 2011;17(6):659-76.

PAL R, VENKATARAMANA NK, BANSAL A, et al. Ex vivo-expanded autologous bone marrow-derived mesenchymal stromal cells in human spinal cord injury/paraplegia: a pilot clinical study. Cytotherapy. 2009;11(7):897-911.

PANEPUCCI RA, SIUFI JL, SILVA WA JR et al. Comparison of gene expression of umbilical cord vein and bone marrow-derived mesenchymal stem cells. Stem Cells. 2004;22(7):1263-78.

PAPADAKI HA, TSAGOURNISAKIS $M$, MASTORODEMOS $V$ et al. Normal bone marrow hematopoietic stem cell reserves and normal stromal cell function support the use of autologous stem cell transplantation in patients with multiple sclerosis. Bone Marrow Transplant. 2005;36(12):1053-63.

PAPADAKI HA, KRITIKOS HD, GEMETZI C et al. Bone marrow progenitor cell reserve and function and stromal cell function are defective in rheumatoid arthritis: evidence for a tumor necrosis factor alpha-mediated effect. Blood. 2002; 99(5):1610-9.

PARK HC, SHIM YS, HA Y et al. Treatment of complete spinal cord injury patients by autologous bone marrow cell transplantation and administration of granulocyte-macrophage colony stimulating factor. Tissue Eng. 2005;11(5-6):913-22.

PAYNE N, SIATSKAS C, BERNARD CC. The promise of stem cell and regenerative therapies for multiple sclerosis. J Autoimmun. 2008; 31(3):288-94.

PENDER MP, GREER JM. Immunology of multiple sclerosis. Curr Allergy Asthma Rep. 2007;7(4):285-92.

PERRY JM, HE XC, SUGIMURA R et al. Cooperation between both Wnt/\{beta\}-catenin and PTEN/PI3K/Akt signaling promotes primitive hematopoietic stem cell self-renewal and expansion. Genes Dev. 2011;25(18):1928-42. 
PETERSON LK, FUJINAMI RS. Inflammation, demyelination, neurodegeneration and neuroprotection in the pathogenesis of multiple sclerosis. J Neuroimmunol. 2007;184(1-2):37-44.

PITTENGER MF, MACKAY AM, BECK SC et al. Multilineage potential of adult human mesenchymal stem cells. Science. 1999;284(5411):143-7.

PIU JC, ALLMAN D, XU L et al. Notch1 expression in early lymphopoiesis influences B versus $T$ lineage determination. Immunity. 1999;11(3):299-308.

POLAK R, BUITENHUIS MT. The PI3K/PKB signaling module as key regulator of hematopoiesis: implications for therapeutic strategies in leukemia. Blood. 2012;119(4):911-23.

POPAT U, KRANCE R. Haematopoietic stem cell transplantation for autoimmune disorders: the American perspective. Br J Haematol. 2004;126(5):637-49.

POPE RM. Apoptosis as a therapeutic tool in rheumatoid arthritis. Nat Rev Immunol. 2002;2(7):52735.

POSER CM, PATY DW, SCHEINBERG L et al. New diagnostic criteria for multiple sclerosis: guidelines for research protocols. Ann Neurol. 1983;13(3):227-31.

PREVOSTO C, ZANCOLLI M, CANEVALI P, ZOCCHI MR, POGGI A. Generation of CD4+ or CD8+ regulatory $T$ cells upon mesenchymal stem cell-lymphocyte interaction. Haematologica. 2007;92(7):881-8.

RA JC, SHIN IS, KIM SH, et al. Safety of intravenous infusion of human adipose tissue-derived mesenchymal stem cells in animals and humans. Stem Cells Dev. 2011;20(8):1297-308.

RAFEI M. Mesenchymal stromal cell-derived CCL2 suppresses plasma cell immunoglobulin production via STAT3 inactivation and PAX5 induction. Blood. 2008;112(13):4991-8.

RAICEVIC G, ROUAS R, NAJAR M et al. Inflammation modifies the pattern and the function of toll-like receptors expressed by human mesenchymal stromal cells. Hum immunol. 2010;71(3):235-44.

RASMUSSON I, RINGDÉN O, SUNDBERG B, LE BLANC K. Mesenchymal stem cells inhibit the formation of cytotoxic T lymphocytes, but not activated cytotoxic T lymphocytes or natural killer cells. Transplantation. 2003;76(8):1208-13.

RASMUSSON I, RINGDÉN O, SUNDBERG B, LE BLANC K. Mesenchymal stem cells inhibit lymphocyte proliferation by mitogens and alloantigens by different mechanisms. Exp Cell Res. 2005;305(1):33-41.

REN G, ZHANG L, ZHAO X et al. Mesenchymal stem cell-mediated immunosuppression occurs via concerted action of chemokines and nitric oxide. Cell Stem Cell. 2008;2(2):141-50.

REN J, JIN P, SABATINO M et al. Global transcriptome analysis of human bone marrow stromal cells (BMSC) reveals proliferative, mobile and interactive cells that produce abundant extracellular matrix proteins, some of which may affect BMSC potency. Cytotherapy. 2011;13(6):661-74.

RESTON JT, UHL S, TREADWELL JR, NASH RA, SCHOELLES K. Autologous hematopoietic cell transplantation for multiple sclerosis: a systematic review. Mult Scler. 2011;17(2):204-13.

RIOUX JD, ABBAS AK. Paths to understanding the genetic basis of autoimmune disease. Nature. 2005;435(7042):584-9.

RIZZO R, CAMPIONI D, STIGNANI M et al. A functional role for soluble HLA-G antigens in immune modulation mediated by mesenchymal stromal cells. Cytotherapy. 2008;10(4):364-75. 
RODRIGUEZ AM, PISANI D, DECHESNE CA et al. Transplantation of multipotent cell population from adipose tissue induces dystrophin expression in the immunocompetent mdx mouse. $J$ Exp Med. 2005;201(9):1397-405.

ROOZEN PPC, BRUGMAN MH, STAAL FJT. Differential requirements for Wnt and Notch signaling in hematopoietic versus thymic niches. Ann NY Acad Sci. 2012;1266:78-93.

ROSENBERG S, ZHANG H, ZHANG J. FADD deficiency impairs early hematopoiesis in the bone marrow. J Immunol. 2011;186(1):203-13.

ROSSI DJ, JAMIESON CH, WEISSMAN IL. Stems cells and the pathways to aging and cancer. Cell. 2008;132(4):681-96.

RYAN KR, PATEL SD, STEPHENS LA, ANDERTON SM. Death, adaptation and regulation: The three pillars of immune tolerance restrict the risk of autoimmune disease caused by molecular mimicry. $J$ Autoimmun. 2007;29(4):262-71.

SACCARDI R, FREEDMAN MS, SORMANI MP et al. A prospective, randomized, controlled trial of autologous haematopoietic stem cell transplantation for aggressive multiple sclerosis: a position paper. Mult Scler. 2012;18(6):825-34.

SELMANI Z, NAJI A, ZIDI I et al. HLA-G5 secretion by human mesenchymal stem cells is required to suppress $\mathrm{T}$-lymphocyte and NK function and to induce CD4+CD25highFOXP3+ regulatory $\mathrm{T}$ cells. Stem Cells. 2007;26(1):212-22.

SEKE ETET PF, VECCHIO L, BOGNE KAMGA P, NCHIWAN NUKENINE E, KRAMPERA M, NWABO KAMDJE AH. Normal hematopoiesis and hematologic malignancies: Role of canonical Wnt signaling pathway and stromal microenvironment. Biochim Biophys Acta. 2013;1835(1):1-10.

SERAFINI B, ROSICARELLI B, MAGLIOZZI R, STIGLIANO E, ALOISI F. Detection of ectopic B-cell follicles with germinal centers in the meninges of patients with secondary progressive multiple sclerosis. Brain Pathol. 2004;14(2):164-74.

SERFLING E, KLEIN-HESSLING S, PALMETSHOFER A, BOPP T, STASSEN M, SCHMITT E. NFAT transcription factors in control of peripheral T cell tolerance. Eur J Immunol. 2006;36(11):2837-43.

SHARIEF MK, SEMRA YK. Upregulation of the inhibitor of apoptosis proteins in activated T lymphocytes from patients with multiple sclerosis. J Neuroimmunol. 2001;119(2):350-7.

SHARIEF MK, DOUGLAS M, NOORI M, SEMRA YK. The expression of pro- and anti-apoptosis Bcl-2 family proteins in lymphocytes from patients with multiple sclerosis. $J$ Neuroimmunol. 2002;125(12):155-62.

SHARIEF MK, MATTHEWS H, NOORI MA. Expression ratios of the $\mathrm{Bcl}-2$ family proteins and disease activity in multiple sclerosis. J Neuroimmunol. 2003;134(1-2):158-65.

SHEVCHENKO JL, KUZNETSOV AN, IONOVA TI et al. Autologous hematopoietic stem cell transplantation with reduced-intensity conditioning in multiple sclerosis. Exp Hematol. 2012;40(11):892-8.

SILVA WA JR, COVAS DT, PANEPUCCI RA et al. The profile of gene expression of human marrow mesenchymal stem cells. Stem Cells. 2003;21(6):661-9.

SILVER JD, RITCHIE ME, SMYTH GK. Microarray background correction: maximum likelihood estimation for the normal-exponential convolution. Biostatistics. 2009;10(2):352-63.

SOSPEDRA M, MARTIN R. Immunology of multiple sclerosis. Annu Rev Immunol. 2005;23:683-747.

STAAL FJ, LUIS TC, TIEMESSEN MM. WNT signalling in the immune system: WNT is spreading its wings. Nat Rev Immunol. 2008;8(8):581-93. 
STEINMAN L. A molecular trio in relapse and remission in multiple sclerosis. Nat Rev Immunol. 2009;9(6):440-7.

STYS PK, ZAMPONI GW, VAN MINNEN J, GEURTS JJG. Will the real multiple sclerosis please stand up? Nat Rev Neurosci. 2012; 13(7):507-14.

SUBRAMANIAN A, TAMAYO P, MOOTHA VK, MUKHERJEE S, EBERT BL et al. Gene set enrichment analysis: a knowledge-based approach for interpreting genome-wide expression profiles. Proc Natl Acad Sci USA. 2005;102(43):15545-50.

SUDRES M, NOROL F, TRENADO A et al. Bone marrow mesenchymal stem cells suppress lymphocyte proliferation in vitro but fail to prevent graft versus- host disease in mice. J Immunol. 2006;176(12):7761-7.

SUGIMURA R, HE XC, VENKATRAMAN A et al. Noncanonical Wnt signaling maintains hematopoietic stem cells in the niche. Cell. 2012;150(2):351-65.

SUGIYAMA T, KOHARA H, NODA M, NAGASAWA T. Maintenance of the hematopoietic stem cell pool by CXCL12-CXCR4 chemokine signaling in bone marrow stromal cell niches. Immunity. 2006; 25(6):977-88.

SUN LY, ZHANG HY, FENG XB, HOU YY, LU LW, FAN LM. Abnormality of bone marrow-derived mesenchymal stem cells in patients with systemic lupus erythematosus. Lupus. 2007;16(2):121-8.

SUVA D, PASSWEG J, ARNAUDEAU S, HOFFMEYER P, KINDLER V. In vitro activated human T lymphocytes very efficiently attach to allogenic multipotent mesenchymal stromal cells and transmigrate under them. J Cell Physiol. 2008;214(3):588-94.

SYKES M, NIKOLIC B. Treatment of severe autoimmune disease by stem cell transplantation. Nature. 2005;435(7042):620-7.

TALORA C, CAMPESE AF, BELLAVIA D et al. Pre-TCR-triggered ERK signaling-dependent downregulation of E2A activity in Notch3-induced T-cell lymphoma. EMBO Rep. 2003;4(11):1067-72.

TANG F, WU Q, IKENOUE T, KUN-LIANG GUAN, YANG LIU, PAN ZHENG. A critical role for Rictor in T lymphopoiesis. J Immunol. 2012;189(4):1850-7.

TODARO M, ZEUNER A, STASSI G. Role of apoptosis in autoimmunity. J Clin Immunol. 2004;24(1):1-11.

TOTHOVA Z, KOLLIPARA R, HUNTLY BJ et al. FoxOs are critical mediators of hematopoietic stem cell resistance to physiologic oxidative stress. Cell. 2007;128(2):325-39.

TRAPP BD, NAVE KA. Multiple sclerosis: an immune or neurodegenerative disorder? Annu Rev Neurosci. 2008;31/247-69.

TZARTOS JS, FRIESE MA, CRANER MJ et al. Interleukin-17 production in central nervous systeminfiltrating $T$ cells and glial cells is associated with active disease in multiple sclerosis. Am J Pathol. 2008;172(1):146-55.

TYNDALL A, SACCARDI R. Hematopoietic stem cell transplantation in the treatment of severe autoimmune disease - results from phase I/II studies, prospective randomized trials and future directions. Clin. Exp. Immunol. 2005;141(1):1-9.

TYNDALL A, UCCELLI A. Multipotent mesenchymal stromal cells for autoimmune diseases: teaching new dogs old tricks. Bone Marrow Transplant. 2009;43(11):821-8.

UCCELLI A, MORETTA L, PISTOIA V. Immunoregulatory function of mesenchymal stem cells. Eur J Immunol. 2006;36(10):2566-73. 
UCCELLI A, MORETTA L, PISTOIA V. Mesenchymal stem cells in health and disease. Nat ReV Immunol. 2008;8(9):726-36.

UCCELLI A, PROCKOP DJ. Why should mesenchymal stem cells (MSCs) cure autoimmune diseases? Curr Opin Immunol. 2010;22(6):768-74.

UCCELLI A, LARONI A, FREEDMAN MS. Mesenchymal stem cells for the treatment of multiple sclerosis and other neurological diseases. Lancet Neurol. 2011;10(7):649-56.

UCCELLI A, LARONI A, FREEDMAN MS. Mesenchymal stem cells as treatment for MS - progress to date. Mult Scler. 2012;Nov1.

VAN BEKKUM DW. Experimental basis of hematopoietic stem cell transplantation for treatment of autoimmune diseases. J Leukoc Biol. 2002;72(4):609-20.

VAN BEKKUM DW. Experimental basis for the treatment of autoimmune diseases with autologous hematopoietic stem cell transplantation. Bone Marrow Transplant. 2003;32 Suppl 1:S37-9.

VAN BEKKUM DW. Stem cell transplantation for autoimmune disorders. Preclinical experiments. Best Pract Res Clin Haematol. 2004;17(2):201-22.

VAUX DL, FLAVELL RA. Apoptosis genes and autoimmunity. Curr Opin Immunol. 2000;12(6):719-24.

VIEIRA NM, BUENO CR JR, BRANDALISE $V$ et al. Sjl dystrofic mice express a siginificant amount of human muscle proteins following systemic delivery of human adipose-derived stromal cells without immunosupression. Stem Cells. 2008;26(9):2391-8.

VIGLIETTA V, BAECHER-ALLAN C, WEINER HL, HAFLER DA. Loss of functional suppression by CD4+CD25+ regulatory T cells in patients with multiple sclerosis. J Exp Med. 2004;199(7):971-9.

VIRLEY DJ. Developing therapeutics for the treatment of multiple sclerosis. NeuroRx. 2005;2(4):63849.

VOLTARELLI JC, OUYANG J. Hematopoietic stem cell transplantation for autoimmune diseases in developing countries: current status and future prospectives. Bone Marrow Transplant. 2003;32 Suppl 1:S69-71.

VOLTARELLI JC, COURI CE, STRACIERI AB et al. Autologous nonmyeloablative hematopoietic stem cell transplantation in newly diagnosed type 1 diabetes mellitus. JAMA. 2007;297(14):1568-76.

VON BOEHMER H. Mechanisms of suppression by suppressor T cells. Nat Immunol. 2005;6(4):33844.

WAGNER W, BORK S, HORN $P$ et al. Aging and replicative senescence have related effects on human stem and progenitor cells. Plos One. 2009;4(6):e5846.

WANG LD, WAGERS AJ. Dynamic niches in the origination and differentiation of haematopoietic stem cells. Nat Rev Mol Cell Biol. 2011;12(10):643-55.

WATERMAN RS, TOMCHUCK SL, HENKLE SL, BETANCOURT AM. A new mesenchymal stem cell (MSC) paradigm: polarization into a pro-inflammatory MSC1 or an immunosuppressive MSC2 phenotype. Plos One. 2010;5(4):e10088.

WILKERSON MD, HAYES DN. Consensus Cluster Plus: a class discovery tool with confidence assessments and item tracking. Bioinformatics. 2010;26(12):1572-3.

WILSON A, TRUMPP A. Bone-marrrow haematopoietic-stem-cell niches. Nat Rev Immunol. 2006;6(2)93-106. 
WING K, SAKAGUCHI S. Regulatory T cells exert checks and balances on self tolerance and autoimmunity. Nat Immunol. 2010;11(1):7-13.

YAMOUT B, HOURANI R, SALTI $\mathrm{H}$ et al. Bone marrow mesenchymal stem cell transplantation in patients with multiple sclerosis: a pilot study. J Neuroimmunol. 2010;227(1-2):185-9.

YAÑEZ R, LAMANA ML, GARCÍA-CASTRO J, COLMENERO I, RAMÍREZ M, BUEREN JA. Adipose tissue-derived mesenchymal stem cells have in vivo immunosuppressive properties applicable for the control of the graft-versus-host disease. Stem Cells. 2006;24(11):2582-91.

YAÑEZ R, OVIEDO A, ALDEA M, BUEREN JA, LAMANA ML. Prostaglandin E2 plays a key role in the immunosuppressive properties of adipose and bone marrow tissue-derived mesenchymal stromal cells. Exp Cell Res. 2010;316(19):3109-23.

YANG SH, PARK MJ, YOON IH et al. Soluble mediators from mesenchymal stem cells suppress T cell proliferation by inducing IL-10. Exp Mol Med. 2009;41(5):315-24.

YIN G, HOU R, LI J, ZHANG J, LI X, ZHANG K. Expression of Notch Receptor and Its Target Gene Hes-1 in Bone Marrow CD34+ Cells from Patients with Psoriasis. Dermatology. 2012;Oct 2.

YOO HJ, YOON SS, PARK SY et al. Gene Expression Profile during Chondrogenesis in Human Bone Marrow derived Mesenchymal Stem Cells using a cDNA Microarray. J Korean Med Sci. 2011;26(7): 851-8.

ZAFRANSKAYA MM, NIZHEHARODOVA DB, YURKEVICH MY et al. In vitro assessment of mesenchymal stem cells immunosuppressive potential in multiple sclerosis patients. Immunol Lett. 2012; Oct 23.

ZAPPIA E, CASAZZA S, PEDEMONTE E et al. Mesenchymal stem cells ameliorate experimental autoimmune encephalomyelitis inducing T-cell anergy. Blood. 2005;106(5):1755-61.

ZHANG J, LI Y, CHEN J et al. Human bone marrow stromal cell treatment improves neurological functional recovery in EAE mice. Exp. Neurol. 2005;195(1):16-26.

ZHANG J, LI Y, LU M et al. Bone marrow stromal cells reduce axonal loss in experimental autoimmune encephalomyelitis mice. J Neurosci Res. 2006;84(3):587-95.

ZOZULYA AL, WIENDL H. The role of regulatory T cells in multiple sclerosis. Nat Clin Pract Neurol. 2008;4(7):384-98. 


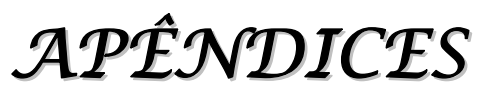




\section{Apêndice I}

Tabela: Número de células e pureza das células-tronco hematopoéticas $\mathrm{CD} 4^{+}$isoladas de pacientes com esclerose múltipla e de doadores saudáveis de medula óssea.

\begin{tabular}{cccc}
\hline \hline Pacientes/ Controles & Período & No células CD34 $^{+}$ & Pureza CD34 $^{+}$ \\
\hline EM02 & pré-Tx & $1,50 \times 10^{6}$ & $83,88 \%$ \\
EM04 & pré-Tx & $2,0 \times 10^{6}$ & $94,38 \%$ \\
EM05 & pré-Tx & $0,60 \times 10^{6}$ & $97,17 \%$ \\
EM06 & pré-Tx & $1,23 \times 10^{6}$ & $98,24 \%$ \\
EM07 & pré-Tx & $1,76 \times 10^{6}$ & $99,08 \%$ \\
EM08 & pré-Tx & $0,80 \times 10^{6}$ & $98,18 \%$ \\
EM09 & pré-Tx & $1,95 \times 10^{6}$ & $98,36 \%$ \\
EM10 & pré-Tx & $0,45 \times 10^{6}$ & $97,70 \%$ \\
EM43 & pré-Tx & $0,60 \times 10^{6}$ & $80,19 \%$ \\
EM46 & pré-Tx & $1,0 \times 10^{6}$ & $91,66 \%$ \\
EM48 & pré-Tx & $0,56 \times 10^{6}$ & $98,16 \%$ \\
EM49 & pré-Tx & $0,35 \times 10^{6}$ & $92,85 \%$ \\
EM51 & pré-Tx & $0,16 \times 10^{6}$ & $82,24 \%$ \\
EM54 & pré-Tx & $0,81 \times 10^{6}$ & $89,33 \%$ \\
EM55 & pré-Tx & $0,67 \times 10^{6}$ & $90,01 \%$ \\
EM57 & pré-Tx & $0,89 \times 10^{6}$ & $94,23 \%$ \\
EM58 & pré-Tx & $4,0 \times 10^{5}$ & $93,36 \%$ \\
EM59 & pré-Tx & $1,20 \times 10^{6}$ & $93,51 \%$ \\
NM036 & - & $0,75 \times 10^{6}$ & $82,66 \%$ \\
NM038 & - & $3,37 \times 10^{6}$ & $95,67 \%$ \\
NM039 & - & $3,51 \times 10^{6}$ & $97,44 \%$ \\
NM040 & - & $3,17 \times 10^{6}$ & $90,01 \%$ \\
NM042 & - & $1,27 \times 10^{6}$ & $95,55 \%$ \\
NM043 & - & $0,85 \times 10^{6}$ & $81,40 \%$ \\
NM044 & - & $0,90 \times 10^{6}$ & $91,06 \%$ \\
\hline \hline
\end{tabular}

pré-Tx: período pré-TACTH; As células isoladas por coluna imunomagnética foram marcadas com anticorpo monoclonal para o antígeno de superfície CD34 para análise da pureza. 


\section{Apêndice II}

A)

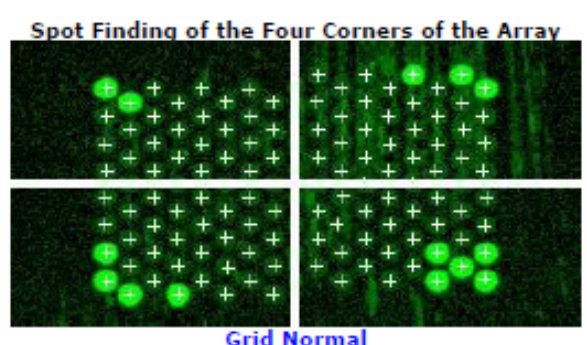

C) Agilent SpikeIns: Log(Signal) vs. Log(Relative

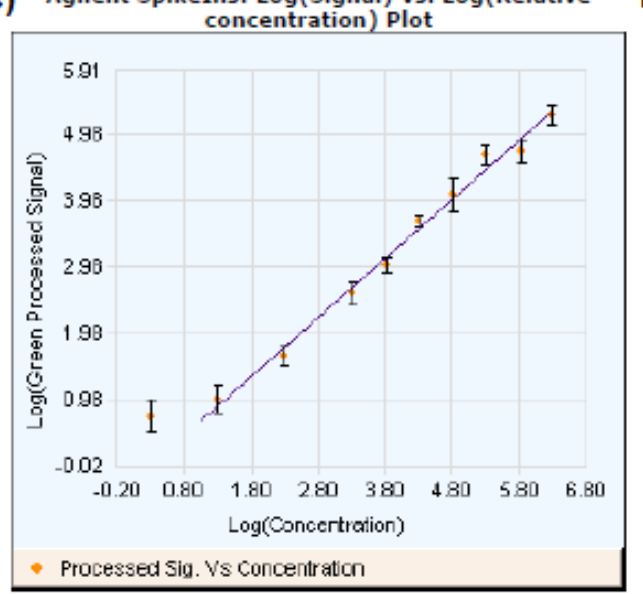

E)

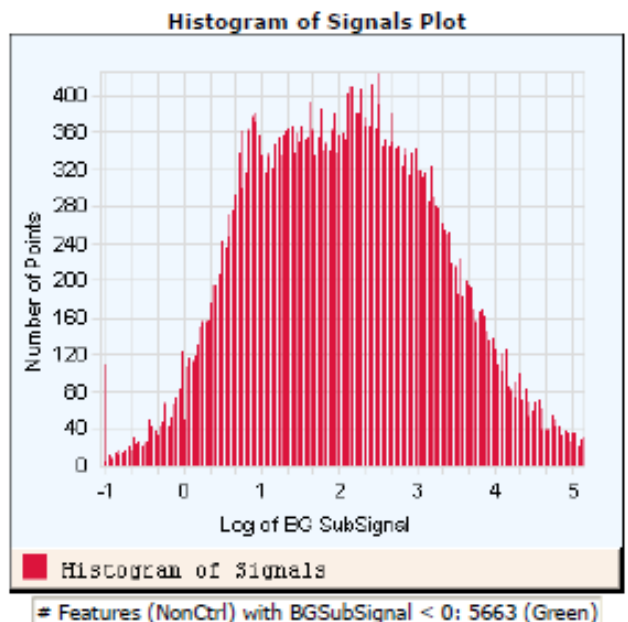

B) Net Signal Statistics

$$
\text { Agilent SpikeIns: }
$$

Green

\begin{tabular}{lr}
\hline = Saturated Features & 0 \\
$99 \%$ of Sig. Distrib. & 251000 \\
$50 \%$ of Sig. Distrib. & 1424 \\
$1 \%$ of Sig. Distrib. & 50 \\
& Non-Control probes:
\end{tabular}

Non-Control probes:

Green

= Saturated Features

$99 \%$ of Sig. Distrib.

$50 \%$ of Sig. Distrib.

$1 \%$ of Sig. Distrib.

D)

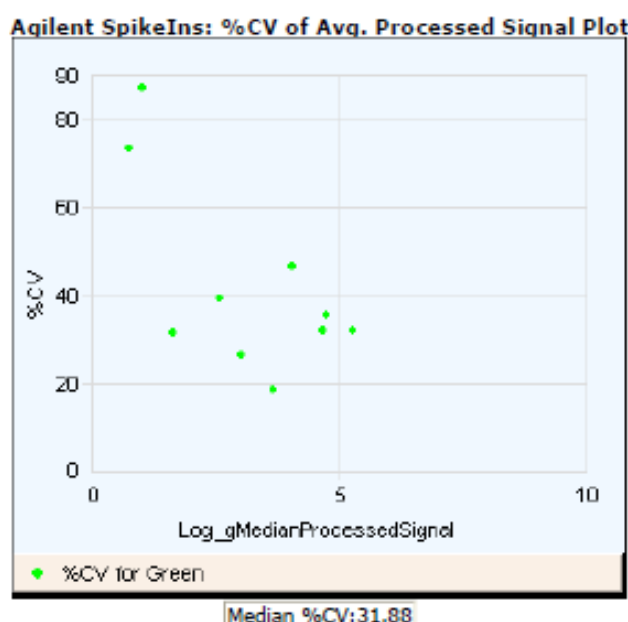

F)

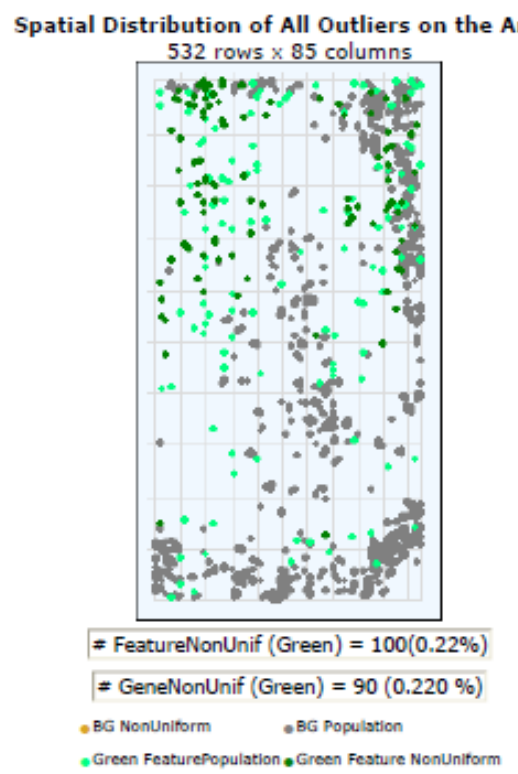

Figura: Dados de hibridação das lâminas de microarrays gerados pelo Agilent Feature extraction software QC report. (A) Representação dos spots localizados nos quatro lados da lâmina 251485050841 (B) Tabela da estatística do sinal de fluorescência dos spikelns e sondas não controle. (C) Curva log da concentração dos spikes vs. log sinal de fluorescência. (D) Porcentagem de CV de fluorescência do microarray; (E) Histograma do sinal do microarray; (F) Distribuição dos outliers no microarray. 
ANNEXOS 


\section{ANEXO I}

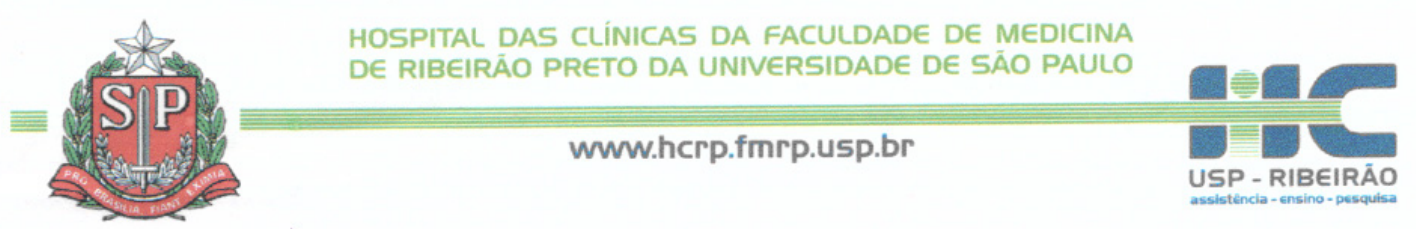

Ribeirão Preto, 18 de março de 2009

Oficio $\mathrm{n}^{\circ} 820 / 2009$

$\mathrm{CEP} / \mathrm{SPC}$

Prezados Senhores,

O trabalho intitulado “ANÁLISE DA EXPRESSÃO GÊNICA POR MICROARRAYS DE CÉLULAS-TRONCO HEMATOPOÉTICAS E MESENQUIMAIS DE PACIENTES COM ESCLEROSE MÚLTIPLA" foi analisado pelo Comitê de Ética em Pesquisa, em sua $282^{a}$ Reunião Ordinária realizada em 16/03/2009 e enquadrado na categoria: APROVADO, bem como o Termo de Consentimento Livre e Esclarecido, de acordo com o Processo HCRP n ${ }^{\circ}$ 2596/2009.

Este Comitê segue integralmente a Conferência Internacional de Harmonização de Boas Práticas Clínicas (IGH-GCP), bem como a Resolução $n^{\circ}$ 196/96 CNS/MS.

Lembramos que devem ser apresentados a este CEP, 0

Relatório Parcial e o Relatório Final da pesquisa.

Atenciosamente.

PROF. DR. SERGIO PEREIRA DA CUNHA

Coordenador do Comitê de Ética em

Pesquisa do HCRP e da FMRP-USP

Ilustríssimos Senhores

GISLANE LELIS VILELA DE OLIVEIRA

PROF. DR. JÚLIO CÉSAR VOLTARELLI (Orientador)

Depto. de Clínica Médica 


\begin{abstract}
ANEXO II
Bone-marrow mesenchymal stromal cells isolated from multiple sclerosis patients have differential gene expression profile and decreased suppressive function compared to healthy counterparts
\end{abstract}

Gislane L V Oliveira ${ }^{a}$, Kalil W A de Lima ${ }^{a}$, Amanda M Colombini ${ }^{a}$, Rodrigo A Panepucci ${ }^{a}$, Daniel G Pinheiro ${ }^{a}$, Patricia V Bonini ${ }^{a}$, Dimas $T$ Covas ${ }^{a, b}$, Doralina Brum ${ }^{c}$, Belinda P Simões $^{\mathrm{a}, \mathrm{b}}$, Eduardo A Donadi ${ }^{\mathrm{b}}$, Kelen C R Malmegrim ${ }^{\mathrm{a}, \mathrm{b}}$

anstituto Nacional de Ciência e Tecnologia em Células-tronco e Terapia Celular, Centro Regional de Hemoterapia da Faculdade de Medicina de Ribeirão Preto, Universidade de São Paulo (USP), Ribeirão Preto, Brazil.

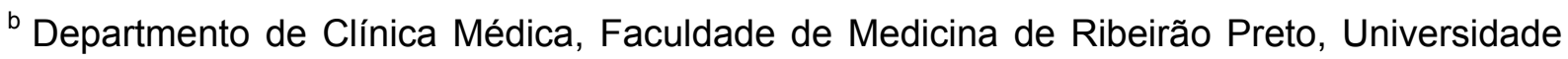
de São Paulo (USP), Ribeirão Preto, Brazil.

${ }^{c}$ Departmento de Neurologia, Psicologia e Psiquiatria, Faculdade de Medicina de Botucatu, Universidade Estadual Paulista (UNESP), Botucatu, Brazil

Address correspondence and reprint requests to Gislane Lelis Vilela de Oliveira, PhD, Fundação Hemocentro de Ribeirão Preto, Rua Tenente Catão Roxo, 2501, 14051-140, Ribeirão Preto, SP, Brasil, Tel.: +55-16-21019605; fax: +55-16-21019309, e-mail address: givilela@usp.br

\title{
ABSTRACT
}

Multiple sclerosis (MS) is a chronic inflammatory autoimmune disorder of the central nervous system, primarily mediated by immune reactions against myelin proteins. Multipotent mesenchymal stromal cells (MSCs) have suppressive effects on immune cells and have been used in the treatment of autoimmune diseases. To compare the role of MSCs obtained from MS patient (pre and post autologous transplantation) with healthy donor MSC, we evaluated the gene expression profile and in vitro immunomodulatory function of these cells. Compared to healthy donor, patient MSCs exhibited: i) senescence features in culture, ii) decreased expression of CD105, CD73, CD44 and HLA-A/B/C molecules, iii) distinct transcription profile, yielding 641 genes differentially expressed, including repressed TGFB1 and HGF genes and FGF and HGF signaling pathways in patient MSCs, iv) reduced antiproliferative effect in pre-transplant when cocultured with allogeneic T-lymphocytes (69.4 $\pm 7.2 \%$ versus $52.1 \pm 5.6 \% ; P=0.024)$, v) no significant differences were observed regarding 
the percentages of regulatory cells recovered from MSC cocultures, vi) decreased IL-10 and TGF- $\beta$ secretion in supernatants of cocultures of patient MSCs with allogeneic lymphocytes (pre-transplant IL-10: $53.8 \pm 49.4$, TGF- $\beta$ : $59.4 \pm 24.6 \mathrm{pg} / \mathrm{mL}$; post-transplant IL-10: $54.5 \pm$ $13.8 \mathrm{pg} / \mathrm{mL}$, TGF- $\beta$ : $122.0 \pm 14.8 \mathrm{pg} / \mathrm{mL}$; healthy donor IL-10: $109.9 \pm 64.6$; TGF- $\beta: 226.6 \pm$ $153.2 \mathrm{pg} / \mathrm{mL} ; P<0.05$ for all comparisons). Considering that patient MSCs exhibited phenotypic changes, differential transcriptional profile and functional defects implicated on their immunomodulatory and immunosuppressive activity of MSCs, we may suggest that bone-marrow healthy donor MSCs should be more suitable to and considered to be further investigated in clinical settings.

Key words: multiple sclerosis, multipotent mesenchymal stromal cells, hematopoietic stem cell transplantation

\section{INTRODUCTION}

Multiple sclerosis (MS) is a chronic inflammatory autoimmune disorder of the central nervous system, affecting more than one million people worldwide [Goverman, 2009; Nylander e Hafler, 2012]. The disease is primarily mediated by T CD $4^{+}$Th1 cells, Th17 cells, T CD8 ${ }^{+}$ cells, B lymphocytes and activated microglia [Nylander e Hafler, 2012]. These immune cells cross the blood-brain barrier and react against myelin proteins, causing demyelination, axonal damage and progressive neurologic disability in young adults [Steinman, 2009; Stys, 2012].

The conventional treatment for MS patients includes the use of immunomodulators that decrease inflammation in the central nervous system and stabilize the disease [Hohlfeld \& Wekerle, 2004; Virley, 2005]. Interventions using autologous hematopoietic stem cells after intense immunosuppression regimens have been used with satisfactory results, stabilizing the disease and promoting clinical improvement in some patients [Burt et al., 2005; Muraro et al., 2005; Burt et al., 2008; Burt et al., 2012].

Several reports have shown that bone-marrow-derived mesenchymal stromal cells (MSCs) are able to modulate innate and adaptive immunity cell responses, inducing tolerance [Uccelli et al., 2008; Dazzi et al., 2012; De Miguel et al., 2012; Le Blanc e Mougiakakos, 2012], supporting the rationale for its application in the treatment of MS patients [Uccelli \& Prockop, 2010; Karussis, 2012; Cohen, 2013]. Among the immunosuppressive and immunorregulatory functions, MSCs have the ability to inhibit: i) T CD4 ${ }^{+}$cell proliferation; ii) pro-inflammatory Th1 and Th17 cytokine secretion, iv) cytotoxicity and proliferation of $\mathrm{NK}$ and $\mathrm{T} \mathrm{CD8}{ }^{+}$cells, v) the differentiation of monocytes into dendritic cells, vi) apoptosis and respiratory burst of neutrophils, vii) B cells proliferation and antibody production [Uccelli et al., 2008; Le Blanc e Mougiakakos, 2012]. In addition, MSCs induce the generation and expansion of regulatory $T$ 
cells [Selmani et al., 2007; Di lanni et al, 2008; English et al., 2009; Burr et al., 2013; English, 2013]. Several mechanisms have been shown to be responsible for the immunomodulatory properties of MSCs and currently there is a consensus that soluble factors release by these cells play a key role in their suppressive and immunomodulatory activity [Bassi et al., 2012; Dazzi et al., 2012]. Some of these soluble factors are constitutively produced by MSCs and other factors are induced after licensing of MSCs in inflammatory microenvironments [Dazzi \& Marelli-Berg, 2008; Bassi et al., 2012; Dazzi et al., 2012]. Among these soluble factors are IDO (indoleamine 2,3-dioxygenase), prostaglandin E2 (PGE2), TGF- $\beta 1$, IL-6, HGF (hepatocyte growth factor), LIF (leukemia inhibitory factor), HLA-G5, chemokines and metalloproteinases [Uccelli et al., 2008; Bassi et al., 2012; Dazzi et al., 2012].

The administration of MSCs in experimental autoimmune encephalomyelitis (EAE) in mice suppressed specific T-cell proliferation, decreased IFN- $\gamma$, TNF and IL17 secretion, shifted the cytokine profile to a Th2 polarization, and increased the number of regulatory T cells, [Zappia et al., 2005; Gerdoni et al., 2007; Bai et al., 2009]. In addition, MSCs migrated to the demyelinated areas, where they diminished cellular infiltrate, stimulated oligodendrocytes and astrocytes proliferation through the release of soluble factors, mainly HGF [Bai et al., 2009; Bai et al. 2012], and decreased demyelinated areas and clinical EAE scores [Zhang et al., 2005; Zhang et al., 2006; Kassis et al., 2008; Morando et al., 2012].

Based on EAE studies, some phase I/II clinical trials have been performed treating MS patients with autologous MSCs [Karussis et al., 2010; Yamout et al., 2010; Connick et al., 2012; Uccelli et al., 2012]. However, whether or not autologous patient MSCs have functional defects that could interfere in therapeutic results is a question that has not been answered. To accomplish this goal, we evaluated the in vitro characteristics of autologous and healthy control bone marrow MSCs by studying their differential gene expression profiles and the immunomodulatory function of these cells. Furthermore, we evaluated the gene expression profile of patient MSCs after six months of autologous hematopoietic stem cell transplantation (AHSCT). We showed that patient and control MSCs transcription profiles are distinct and patient MSCs secreted lower amounts of anti-inflammatory cytokines and exhibited decreased ability to inhibit T lymphocyte proliferation.

\section{MATERIALS AND METHODS}

\section{Patients and controls}

A total of 19 patients (12 women), aged 20-49 years (38.2 \pm 9 ), exhibiting progressive MS forms, refractory to corticosteroids and interferon- $\beta$ treatments, were recruited to undergo an autologous hematopoietic stem cell transplantation (AHSCT) clinical trial at the Bone Marrow 
Transplantation Unit of the School of Medicine of Ribeirão Preto, University of São Paulo, Brazil. Patients were diagnosed according to the Poser and colleagues criteria [Poser et al., 1983] by physicians from the Neurology Department of the same hospital and all procedures were approved by the Ethics Committee of the University Hospital of the School of Medicine of Ribeirão Preto (process number 2596/2009). Control group was composed by 18 bone marrow healthy donors (9 women), aged 19-45 years (31.4 \pm 10 ), and recruited by the Bone Marrow Transplantation Unit for allogeneic transplantation for other diseases. Informed written consent was obtained from all individuals before bone marrow aspirate collection. Clinical characteristics at baseline and six months after AHSCT are shown in Table 1.

\section{Isolation and characterization of bone-marrow derived mesenchymal stromal cells}

Bone-marrow aspirate samples (3-5 mL) were collected in the presence of EDTA and mononuclear cells were separated using Ficoll-Hypaque (Amersham-Pharmacia, Uppsala, Sweden) gradient density [Boyum, 1974]. Mononuclear cells $\left(1-4 \times 10^{7}\right)$ were resuspended in $\alpha$-MEM (GIBCO BRL Life Technologies, Grand Island, NY, USA) medium containing 15\% fetal bovine serum (FBS), $2 \mathrm{mM}$ I-glutamine, $100 \mathrm{U} / \mathrm{ml}$ penicillin, $100 \mathrm{U} / \mathrm{ml}$ streptomycin and $100 \mathrm{U} / \mathrm{ml}$ neomycin. Cells were plated and incubated at $37^{\circ} \mathrm{C}$ in $5 \% \mathrm{CO}_{2}$ atmosphere. After seven days, non-adherent cells were removed and culture medium was changed every three days. MSCs were harvested at sub-confluence using 1\% trypsin-EDTA solution (SigmaAldrich, Saint Louis, MO, USA) and cultured until the third passage for cell characterization, RNA extraction and co-culture assays. Cell morphology was analyzed using an inverted microscope (Carl Zeiss, Germany) using the AxioVision 3.0 software. MSCs were analyzed by flow cytometry using the following conjugated monoclonal antibodies: CD90-PE, CD13APC, CD29-APC, CD105-APC, CD73-PE, CD44-FITC, CD166-PE, HLA-ABC-PE, CD146FITC, CD54PE, CD106-FITC, HLA-DR-FITC, CD14-PE, CD31-FITC, CD34-APC e CD45FITC (Becton-Dickinson, San Jose, California, USA). Flow cytometry analysis was performed using a FACSort apparatus (Becton-Dickinson), and 20.000 events were acquired and analyzed by the Cellquest software (Becton-Dickinson).

The ability of MSCs to differentiate into osteogenic and adipogenic lineages was assayed by culturing in specific media. Adipogenic medium consisted of $\alpha-M E M$ medium containing $15 \%$ FBS, supplemented with $10 \mu \mathrm{M}$ dexamethasone, $10 \mu \mathrm{g} / \mathrm{mL}$ insulin (Sigma-Aldrich) and $100 \mathrm{mM}$ indomethacin (Sigma-Aldrich). Osteogenic medium included a-MEM, 7.5\% FBS, supplemented with $0.10 \mu \mathrm{M}$ dexamethasone, $100 \mu \mathrm{M}$ ascorbic acid and $10 \mathrm{mM}$ de $\beta$ glycerophosphate (Reagen, Colombo, PR, Brazil). Culture medium was changed every three days for 27 days. Cultures were stained with Sudam II-Scarlat (Oil red, Sigma-Aldrich) for 
detection of lipids, and von Kossa (Sigma-Aldrich) for detection of mineralized extracellular matrix.

\section{RNA extraction, microarray hybridizations and bioinformatics analysis}

Total RNA was isolated using Trizol methodology (Invitrogen LifeTechnologies, Carlsbad, CA, USA), according to the manufacturer's instruction [Chomczynski \& Sacchi, 1987], purified with RNeasy mini Kit (Qiagen, Valencia, CA, USA) and spectrophotometrically analyzed at 260 and $280 \mathrm{~nm}$ (NanoDrop, ND-1000 UV-VIS, Thermo Fisher Scientific, Walthman, Massachusetts, USA). To evaluate the global gene expression profiles of patient (pre-AHSCT N=4; post-AHSCT N=4) and control MSCs ( $\mathrm{N}=4)$ we used the Agilent one-color (Cy3 fluorochrome) microarray-based gene expression platform according to manufacturer's instructions (Agilent Technologies, Santa Clara, CA, USA). RNA (1 $\mu \mathrm{g})$ was amplified and labeled using the low RNA input linear amplification kit plus (Agilent). Complementary RNA (cRNA) samples were hybridized onto whole human genome $4 \times 44 \mathrm{~K}$ V2 (Agilent) overnight at $65^{\circ} \mathrm{C}$, followed by washing steps. Slides were scanned using GenePix 4000B (Axon Instruments, Foster City, CA, USA) and the hybridization signals were extracted using the Agilent Feature Extraction software. Bioinformatics analyses include Gene Set Enrichment Analysis (Subramanian et al., 2005), DAVID (Huang et al., 2009). and Ingenuity pathways systems (IngenuityR Systems, Redwood, CA, USA). Lists of genes represented in the microarray used in this study are available online at the MIAME public database ArrayExpress, accession \#.

\section{Coculture assays}

To test the inhibitory effect of MSCs isolated from MS patients (pre-transplantation $N=10$; post-transplantation $\mathrm{N}=9$ ) and healthy controls $(\mathrm{N}=16)$ on the allogeneic lymphocyte proliferation, we used the carboxyfluorescein diacetate succinimidyl ester (CFSE - invitrogen) dilution method and assessed the proliferation percentages by flow cytometry. Peripheral blood mononuclear cells (PBMCs) isolated from healthy donors were separated by density gradient, labeled with CFSE and resuspended in RPMI 1640 medium supplemented with 5\% human albumin (concentration of $0.5 \times 10^{6} \mathrm{cells} / \mathrm{mL}$ ). The CFSE labeled-PBMCs were added to the wells $(1 \mathrm{~mL} /$ well) containing patient or control MSCs, previously adhered in six different dilutions (MSCs: PBMCs = 1:2, 1:5, 1:10, 1:20, 1:50 and 1:100) in the presence of $0.5 \mu \mathrm{g} / \mathrm{mL}$ of phytohemagglutinin (PHA, Sigma-Aldrich). Cocultures were incubated for 5 days at $37^{\circ} \mathrm{C}$ with $5 \% \mathrm{CO} 2$. On the fifth day of coculture, PBMCs were harvested, stained with anti-CD3PE 
and analyzed by flow cytometry. Control wells consisted of CFSE-labeled PBMCs stimulated with PHA in the absence of MSCs.

To evaluate the effect of MSCs on the induction of regulatory T cells, we studied the frequency of some regulatory subsets of $T$ cells, recovered after coculture assays containing patient and control MSCs and non-CFSE-labeled PBMCs. After 5 days of coculture, PBMCs were harvested and stained for the following $T$ cell subsets witn monoclonal antibodies (Becton-Dickinson or Abcam, Cambridge, United Kingdom): $\mathrm{CD}^{+} \mathrm{CD}^{+}, \mathrm{CD}^{+} \mathrm{CD} 8^{+}$, $\mathrm{CD}^{+} \mathrm{NKT}^{+}, \mathrm{CD}^{+} \mathrm{CD} 25^{\mathrm{hi}}, \mathrm{CD}^{+} \mathrm{CD} 25^{\mathrm{hi}} \mathrm{Foxp}^{+}, \mathrm{CD}^{+} \mathrm{CD} 25^{\mathrm{hi}} \mathrm{CTLA}-4^{+}, \mathrm{CD}^{+} \mathrm{CD} 25^{\mathrm{hi}} \mathrm{GITR}^{+}$, $\mathrm{CD}^{+} \mathrm{CD} 8^{-} \mathrm{Foxp}^{+}, \mathrm{CD}^{+} \mathrm{CD}^{+} \mathrm{HLA}-\mathrm{G}^{+}$and $\mathrm{CD} 3^{+} \mathrm{CD} 8^{+} \mathrm{HLA}-\mathrm{G}^{+}$, and were evaluated by flow cytometry.

\section{Cytokine quantification}

To evaluate the production of cytokines (IFN- $\gamma$, TNF, IL-1 1 , IL-6, IL-10 and TGF- $\beta$ ), HGF and CXCL-10 (IP-10) chemokine, supernatant obtained from the coculture of MSCs and PBMCs (1MSC:2 PBMC proportion) was collected after five days and tested for presence of cytokines using a cytometric bead array (Becton-Dickson) platform . HGF quantification was performed by HGF Human ELISA kit (Invitrogen).

\section{Statistical analysis}

The Kruskal-Wallis test and the Dunn's posttest were used to compare the membrane expression of cluster of differentiation markers between patient (pre and post-transplantation) and control MSCs. Differences in the percentage of lymphocyte proliferation, in frequency of regulatory $T$ cell subsets, and in cytokine levels in coculture assays were analyzed using the parametric One-way ANOVA, followed by Tukey post-test or the non-parametric KruskalWallis test, followed by the Dunn's post-test, according to data distribution. $P$-values lower than 0.05 were considered to be significant. Data were analyzed using the GraphPad Prism, version $5 \cdot 0$.

Gene expression data of MSCs isolated from MS patients and healthy donors were analyzed using the Linear Models for Microarray data package (http://www.tm4.org/mev_manual/limma.html), considered to be significant at $P<0.01$ and fold change $\geq 2.0$. 


\section{RESULTS}

\section{Characterization of multipotent mesenchymal stromal cells}

To characterize multipotent mesenchymal stromal cells isolated from MS patients and controls we evaluated cell morphology in culture, expression of typical surface markers and determined their differentiation potential. MSCs exhibited the following features: i) both patient and control cells exhibit fibroblast-like morphology and ability to adherence to plastic; however, patient MSCs before or after transplantation exhibited a senescent appearance, i. e., at the third passage patient MSC looked like a control MSC at the eighth passage, and lasted longer to reach healthy MSC confluence (Fig. 1A-B); ii) patient and control MSCs expressed CD73, CD90 and CD105 markers and lacked CD14, CD31, CD34 and CD45 markers; however, quantitative differences were observed. Patient MSCs exhibited decreased surface expression of CD29 (pre-AHSCT $=79.25 \pm 3.41 \%$; post-AHSCT $=76.41 \pm$ $4.47 \%$ ), CD105 (pre-AHSCT $=58.70 \pm 7.43 \%$; post- AHSCT $=53.52 \pm 7.64 \%$ ), CD73 (preAHSCT $=67.84 \pm 4.82 \%$; post- AHSCT $=69.30 \pm 3.55 \%$ ) and CD44 (pre- AHSCT $=65.92 \pm$ $5.29 \%$; post- AHSCT $=61.58 \pm 6.42 \%$ ) when compared with control MSCs (CD29=90.42 \pm 2.0\%; CD105=88.68 $\pm 1.40 \%$; CD73=84.73 $\pm 2.72 \%$; CD44=84.90 $\pm 1.80 \%)(P<0.05$, for all comparisons). Furthermore, post- transplant patient MSCs showed decreased surface expression of CD166 (49.37 $\pm 6.68 \%)$, HLA-ABC (70.03 $\pm 4.35 \%)$ and CD146 (21.91 \pm $5.48 \%$ ) when compared with control MSCs (CD166=72.66 $\pm 3.46 \%$; HLA-ABC=70.03 \pm 4.35\%; CD146=42.61 $\pm 7.38 \%)(P<0.05$, for all comparisons) (Fig. 1C); iii) both patient (preor post- AHSCT) and control MSCs exhibited closely similar adipogenic and osteogenic differentiation potential (Fig. 1 D-E).

\section{Patient and control MSCs have distinct transcriptional profiles}

To evaluate hybridization signatures before and after transplantation and to compare hybridization signatures between patient and healthy donor MSCs, we performed a transcriptome analysis using microarrays. To identify functional gene sets we performed a gene set enrichment analysis (GSEA), disclosing some MSC relevant processes, such as cytokine-receptor interactions, IL-10 pathway and cell adhesion molecules processes. Through euclidean hierarchical clustering analysis, we observed that MSCs isolated from MS patients exhibited a distinct gene expression profile when compared to healthy donor MSCs (Fig. 2A). The statistical analysis showed 641 genes differentially expressed genes $(P<0.01$; $F C \geq 2.0$ ), comprising 262 repressed and 379 induced genes, showed in Volcano plot (Fig. 2B). The majority of induced genes were included in the following categories: G-protein 
coupled signaling receptors, intracellular signaling cascades, cellular adhesion regulation, immune response processes regulation, tissue remodeling regulation. Repressed genes were included in categories: transcriptional regulation, GTPases-mediated signal transduction, Ras-protein signal transduction and $\mathrm{T}$ lymphocyte activation. Among the significant and differentially expressed genes, we observed the modulation of genes related to the immunomodulatory capacity of MSCs, such as a downregulation of TGFB1 and HGF genes and a upregulation of IL10, IL6, IFNGR1 and IFNGR2, as shown in the heatmap of Fig. 3A. Furthermore, the search for relevant MSC-related pathways, by using the Ingenuity Pathway Analysis program, we found significant modulation of the FGF and HGF signaling pathways (Fig 3B-C). In FGF signaling, many genes were repressed (FGF3, FGFBP3, FGFR1, GAB1, AKT2, PTPN11), exception made to FGF2 that was induced. Similarly, in the HGF signaling, HGF and other transducing signaling genes (PLC $\gamma, P I 3 K, A K T, C R K L$, $C D C 42, C D K 2)$ were repressed, and the genes RAS, PKC, RAP and IL6, which encode downstream HGF signaling molecules were induced.

Regarding the transcriptional profiles of patient MSCs before and after autologous hematopoietic stem cell transplantation, two clusters were observed, one grouping healthy donor MSCs and the other MSC patients. The transcription profile after transplantation was distinct of that before transplantation, but both were distinct from that displayed by healthy donor MSCs. Although we have observed 81 differentially expressed genes before and after transplantation, most of them were induced in post-transplant MSCs $(P<0.01 ; \mathrm{FC} \geq 2.0)$, data mining using the above mentioned softwares did not reveal pathways exhibiting biological relevance for MSCs; however, induced genes were included in the following categories: DNA metabolic processes, DNA replication, ribonucleoproteins complex, structural constituents of ribosomes, protein complex assembly and biogenesis protein complex (data not shown).

\section{Patient MSCs have decreased ability to inhibit T-cell proliferation}

Once the patient MSCs showed significant modulation of genes involved in the immunomodulatory cell activity, we evaluated the antiproliferative activity of patient (pretransplantion and post- AHSCT) and healthy donor MSCs in coculture assays. We observed that both patient (pre- and post-AHSCT) and control MSCs inhibited in vitro lymphocyte proliferation in a dose-dependent manner (Fig. 4A-C). However, when we compared their relative inhibitory effect, the antiproliferative activity of patient MSCs at pre-AHSCT $(52.15 \pm$ $5.65 \%)$ was significantly reduced $(P=0.024)$ when compared with controls $(69.37 \pm 7.25 \%)$ at $1: 2$ ratio, i. e., while the inhibitory effect of control MSCs reached about $70 \%$, patient MSCs reached approximately $50 \%$ of inhibition (Fig. 4D). No significant differences were observed when the inhibitory activity of post- AHSCT MSC was compared to pre-transplantation or 
healthy donor MSCs. In addition, we observed no correlation between patient's EDSS scores and the proliferation activity of patient MSCs at pre- and post-transplantation.

To further analyze the ability of MSCs to induce regulatory subpopulations, we evaluated the frequency of regulatory cells recovered after five days of coculturing of PBMCs with patient (pre- and post-AHSCT) and control MSCs. We observed no significant differences $(P>0.05)$ in percentages of regulatory subpopulations $\left(\mathrm{CD} 4^{+} \mathrm{CD} 25^{\text {hi }} \mathrm{FOXP} 3^{+}, \mathrm{CD} 4^{+} \mathrm{CD} 25^{\mathrm{hi}} \mathrm{CTLA}-4^{+}\right.$, $\mathrm{CD}^{+}{ }^{+} \mathrm{CD} 25^{\mathrm{hi}} \mathrm{GITR}^{+}, \quad \mathrm{CD}^{+}{ }^{+} \mathrm{CD} 28{ }^{-} \mathrm{FOXP3}^{+}, \quad \mathrm{CD} 4^{+} \mathrm{HLA}-\mathrm{G}^{+}, \quad \mathrm{CD}^{+}{ }^{+} \mathrm{HLA}-\mathrm{G}^{+}$and $\mathrm{CD}^{+} \mathrm{NKT}^{+}$) recovered after cocultures with MSCs isolated from control and patient at pre- and posttransplantation. Furthermore, no differences in percentages of $\mathrm{T} \mathrm{CD}^{+} \mathrm{CD} 4^{+}, \mathrm{CD}^{+} \mathrm{CD} 8^{+}$and $\mathrm{CD} 4^{+} \mathrm{CD} 25^{\mathrm{hi}}$ populations recovered after coculture assays with patient and control MSCs (Table 2).

\section{Patient MSCs have decreased anti-inflammatory cytokine secretion}

Since we observed a decreased antiproliferative capacity of patient MSCs, we quantified some soluble factors in the supernatants collected from cocultures assays of PBMCs with patient (pre- and post-AHSCT) and control MSCs. We found no significant differences $(P>0.05)$ in pro-inflammatory IFN- $\gamma$, TNF, IL-1 $\beta$ and IL-6 cytokine production in supernatants derived from cocultures with patient (pre- and post-AHSCT) and control MSCs (Fig. 5A-D). In addition, HGF and chemokine CXCL-10 secretion were similar in all analyzed cocultures (Fig. 5G-H). However, we observed that the IL-10 $(P=0.016)$ and TGF- $\beta \quad(P=0.0002)$ secretion was significantly decreased in cocultures with patient MSCs at pre-AHSCT (IL$10=53.8 \pm 13.7 \mathrm{pg} / \mathrm{mL} ;$ TGF- $\beta=59.4 \pm 6.8 \mathrm{pg} / \mathrm{mL})$ and post-AHSCT $(\mathrm{IL}-10=54.5 \pm 13.8 \mathrm{pg} / \mathrm{mL}$; TGF- $\beta=122.0 \pm 14.8 \mathrm{pg} / \mathrm{mL}$ ), when compared with cocultures with control MSCs (IL-10: 126.2 $\pm 32.1 \mathrm{pg} / \mathrm{mL}$; TGF- $\beta$ : $226.6 \pm 28.9 \mathrm{pg} / \mathrm{mL}$ ) (Fig. $5 \mathrm{E}-\mathrm{F}$ ).

\section{DISCUSSION}

Bone marrow MSCs have been considered to be an important source for autologous cell therapy for autoimmune diseases, particularly, due to their immunosuppressive properties [Dazzi et al., 2007; Payne et al., 2007; Liu et al., 2012; Uccelli et al., 2012]. The ability of MSCs to modulate the response of immune cells suggests a possible role of these cells in tolerance induction in patients with autoimmune diseases, and supports the rationale for MSC application in the treatment of MS patients [De Miguel et al., 2012; Bassi et al., 2012; Cohen, 2013]. However, it is unclear whether or not MSCs isolated from bone marrow of patients with MS are normal or defective in respect to phenotypic, transcriptional profiles and functional properties when compared to MSCs obtained from healthy donors. Noteworthy, some studies in other autoimmune diseases have shown that MSCs from patients with 
systemic sclerosis have normal functions [Larghero et al., 2008], however, other studies have reported that MSCs from patients with rheumatoid arthritis or systemic lupus erythematosus exhibit altered functions and several abnormalities [Papadaki et al. 2002; Sun et al. 2007].

Regarding to transcriptional analysis, there were no studies concerning the differential expression of MS patient MSCs in comparison to healthy MSCs and patient MSCs after autologous hematopoietic stem cell transplantation. We showed 618 differentially expressed in patient MSCs at pre-transplantation in relation to control MSCs, and genes which were related to decreased immunosuppressive activity of patient MSCs. Furthermore, we found significant alterations in HGF and FGF signaling. Patient MSCs at post-AHSCT have transcriptional profile closer to patient MSCs than healthy MSCs.

Concerning the comparison of the suppressive properties of patient with healthy donor MSCs, we observed that both patient (pre- and post-AHSCT) and healthy donor MSCs inhibited lymphocyte proliferation in a dose-dependent manner; however, healthy donor MSCs exhibited a better antiproliferative performance; i. e., $70 \%$ inhibition for healthy donor cells and $50 \%$ inhibition for patient cells. No correlation between the ability to inhibit proliferation of allogeneic lymphocytes and EDSS values was observed for MS patients in the pre- and post-AHSCT. Mazzanti e colleagues (2008) showed similar antiproliferative activity of MSCs isolated from MS patients and healthy donors. Similar results were reported by Zafranskaya and colleagues (2012), further demonstrating that patient MSCs inhibited autologous and allogeneic lymphocytes and patient MSCs exhibited antiproliferative effects inversely correlated to EDSS [Zafranskaya et al. 2012]. The antiproliferative role of MSCs isolated from patients with other autoimmune diseases (rheumatoid arthritis, scleroderma and Sjogren's syndrome) showed that both MSCs isolated from healthy individuals as autoimmune patients inhibited proliferation of autologous or allogeneic lymphocytes in a dose-dependent manner and that this inhibition was independent of clinical activity of the autoimmune disease [Bocelli-Tyndall et al. 2007].

Several mechanisms have been proposed to explain the immunomodulatory role of MSCs and, currently, there is a consensus that soluble factors released by these cells play a key role in their suppressive activity [Bassi et al., 2012; Dazzi et al., 2012]. Secretion of TGF- $\beta$ by MSCs has been implicated in the activation and expansion of Tregs by several studies [Burr et al., 2013]. Indeed, lymphocytes obtained from healthy individuals stimulated with alloantigen in the presence of MSCs produce large amounts of IL-10, and the blockage of IL10 or its receptor reversed the inhibition of lymphocyte proliferation induced by MSCs [Rasmusson et al. 2005; Yang et al. 2009; Bassi et al. 2012]. Besides, greater production of IL-10 and TGF- $\beta$ is observed when cells are cocultured ensemble in relation to transwell cultures, suggesting that the cell-cell contact is important for the suppressive and 
immunomodulatory activity of MSCs [Nasef et al., 2007; Bassi et al., 2012]. In our study, compared to healthy donor MSCs, the concentrations of IL-10 and TGF- $\beta$ observed in coculture supernatants were significantly lower when patients MSCs (pre- and post-AHSCT) were cocultured with allogeneic lymphocytes.

Some studies have demonstrated the role of human bone-marrow MSCs in the induction, recruitment and proliferation of regulatory T cells [Di lanni et al. 2008; English et al., 2009; English, 2013]. The generation of Treg cells occurs by cell-cell contact, inducing the expression of Foxp3 and CD25 by $\mathrm{CD}^{+} \mathrm{T}$ cells. In addition, soluble factors released by MSCs, particularly TGF- $\beta 1$ and PGE2, play a pivotal role in the induction of CD4 ${ }^{+}$CD25 $5^{\text {hi }}$ oxp3 Tregs [English et al. 2009].

In our study, we detected similar percentages of regulatory subpopulations in both cocultures, using healthy donor control or patient MSCs. Although we have not observed increased percentages of Tregs in cocultures, we cannot exclude the effect of MSCs on the function of these Tregs. Considering that the supernatant of the cocultures with patient MSCs exhibited decreased levels of both, IL-10 and TGF- $\beta$, and considering that the only source of IL-10 in the culture is provided by Tregs, we may argue that patient MSCs may less efficiently induce Tregs.

Overall, the results of the present study showed that MSCs isolated from patients with MS have senescence feature in culture, decreased expression of important immunophenotypic markers and differential transcriptional profile when compared with their healthy counterparts. In addition, patient MSCs exhibited decreased suppressive effect on T-cell proliferation and decreased secretion of anti-inflammatory cytokines. Since the transcriptional and functional alterations are involved in the immunomodulatory and immunosuppressive activity of MSCs, we, therefore, suggest that bone-marrow healthy donor MSCs may be more suitable to and should be considered in clinical settings.

\section{ACKNOWLEDGMENTS}

We thank the Professor Júlio César Voltarelli, mastermind of all this study and the Bone-Marrow Transplantation group of the University Hospital of the School of Medicine of Ribeirão Preto for assistance in collecting bone marrow aspirates from healthy donors and multiple sclerosis patients. These study received financial support from Brazilian governmental agencies, as follows: Fundação de Amparo à Pesquisa do Estado de São Paulo (FAPESP, Foundation for the Support of Research in the State of São Paulo); Fundação Hemocentro de Ribeirão Preto (FUNDHERP, Ribeirão Preto Blood Bank Foundation).

\section{DISCLOSURES}

The authors indicate no potential conflicts of interest. 


\section{REFERENCES}

Bai L, Lennon DP, Eaton $V$ et al. Human bone marrow-derived mesenchymal stem cells induce Th2-polarized immune response and promote endogenous repair in animal models of multiple sclerosis. Glia. 2009;57:1192203.

Bai L, Lennon DP, Caplan Al et al. Hepatocyte growth factor mediates mesenchymal stem cell-induced recovery in multiple sclerosis models. Nat Neurosci. 2012;15:862-70.

Bassi EJ, Almeida DC, Moraes-Vieira, PM, Câmara NOS. Exploring the role of soluble factors associated with immune regulatory properties of mesenchymal stem cells. Stem Cell Rev. 2012; 8(2):329-42.

Bocelli-Tyndall C, Bracci L, Spagnoli G et al. Bone marrow mesenchymal stromal cells (BM-MSCs) from healthy donors and auto-immune disease patients reduce the proliferation of autologous- and allogeneic-stimulated lymphocytes in vitro. Rheumatology. 2007;46(3):403-8.

Boyum A. Separation of blood leukocytes, granulocytes and lymphocytes. Tissue Antigens. 1974;4(4): 269-74.

Burr SP, Dazzi F, Garden OA. Mesenchymal stromal cells and regulatory T cells: the Yin and Yang of peripheral tolerance? Immunol Cell Biol. 2013;91(1):12-8.

Burt RK, Cohen B, Rose $\mathrm{J}$ et al. Hematopoietic stem cell transplantation for multiple sclerosis. Arch Neurol. 2005;62(6):860-4.

Burt RK, Testori A, Craig R, Cohen B, Suffit R, Barr W. Hematopoietic stem cell transplantation for autoimmune diseases: What have we learned? J Autoimmun. 2008;30(3):116-20.

Burt RK, Balabanov R, Voltarelli J, Barreira A, Burman J. Autologous hematopoietic stem cell transplantation for multiple sclerosis- if confused or hesitant, remember: 'treat with standard immune suppressive drugs and if no inflammation, no response'. Mult Scler. 2012;18(6):772-5.

Chomczynski P, Sacchi N. Single-step method of RNA isolation by acid guanidinium thiocyanatephenolchloroform extraction. Anal Biochem. 1987;162(1):156-9.

Cohen JA. Mesenchymal stem cell transplantation in multiple sclerosis. J Neurol Sci. 2013; Jan 4.

Connick P, Kolappan M, Crawley $\mathrm{C}$ et al. Autologous mesenchymal stem cells for the treatment of secondary progressive multiple sclerosis: an open-label phase 2a proof-of-concept study. Lancet Neurol. 2012;11(2):150-6.

Dazzi F, van Laar JM, Cope A, Tyndall A. Cell therapy for autoimmune diseases. Arthritis Res Ther. 2007;9(2):206.

Dazzi F, Marelli-Berg FM. Mesenchymal stem cells for graft-versus-host disease: Close encounters with $\mathrm{T}$ cells. Eur J Immunol. 2008;38(6):1479-82.

Dazzi F, Garden OA. Mesenchymal stromal cells and regulatory T cells: the Yin and Yang of peripheral tolerance? Immunol Cell Biol. 2013;91(1):12-8.

Dazzi F, Lopes L, Weng L. Mesenchymal stromal cells: a key player in 'innate tolerance'? Immunology. 2012;137:206-13.

De Miguel MP, Fuentes-Julián S, Blázquez-Martínez A et al. Immunosuppressive properties of mesenchymal stem cells: advances and applications. Curr Mol Med. 2012;12(5):574-91.

Di lanni M, Del Papa B, De loanni $\mathrm{M}$ et al. Mesenchymal cells recruit and regulate $\mathrm{T}$ regulatory cells. Exp Hematol. 2008;36(3):309-18.

English K, Ryan JM, Tobin L, Murphy MJ, Barry FP, Mahon BP. Cell contact, prostaglandin E(2) and transforming growth factor beta 1 play non-redundant roles in human mesenchymal stem cell induction of CD4+CD25(high) forkhead box P3+ regulatory T cells. Clin Exp Immunol. 2009;156(1):149-60.

English K. Mechanisms of mesenchymal stromal cell immunomodulation. Immunol Cell Biol. 2013;91(1):19-26.

Gerdoni E, Gallo B, Casazza S et al. Mesenchymal stem cells effectively modulate pathogenic immune response in experimental autoimmune encephalomyelitis. Ann Neurol. 2007;61:219-27.

Goverman J. Autoimmune T cell responses in the central nervous system. Nat Rev Immunol. 2009;9(6):393-407. 
Hohlfeld R, Wekerle $\mathrm{H}$. Autoimmune concepts of multiple sclerosis as a basis for selective immunotherapy: from pipe dreams to (therapeutic) pipelines. Proc Natl Acad Sci USA. 2004; 101(Suppl 2):14599-606.

Kassis I, Grigoriadis N, Gowda-Kurkalli B et al. Neuroprotection and immunomodulation with mesenchymal stem cells in chronic experimental autoimmune encephalomyelitis. Arch Neurol. 2008;65(6):753-61.

Karussis D, Karageorgiou C, Vaknin-Dembinsky A et al. Safety and immunological effects of mesenchymal stem cell transplantation in patients with multiple sclerosis and amyotrophic lateral sclerosis. Arch Neurol. 2010; 67(10):1187-94.

Karussis D. Worldwide status of clinical experimentation with stem cells in neurologic diseases. Neurology. 2012;78(17):1334-6.

Larghero J, Farge D, Braccini A et al. Phenotypical and functional characteristics of in vitro expanded bone marrow mesenchymal stem cells from systemic sclerosis patients. Ann Rheum Dis. 2008;67(4):443-9.

Le Blanc K, Mougiakakos D. Multipotent mesenchymal stromal cells and the innate immune system. Nat Rev Immunol. 2012;12:383-96.

Liu SP, Fu RH, Huang SJ et al. Stem Cell Applications in Regenerative Medicine for Neurological Disorders. Cell Transplant. 2012;Oct 31.

Mazzanti B, Aldinucci A, Biagioli T et al. Differences in mesenchymal stem cell cytokine profiles between MS patients and healthy donors: implication for assessment of disease activity and treatment. $J$ Neuroimmunol. 2008;199(1-2)142-50.

Morando S, Vigo T, Esposito $\mathrm{M}$ et al. The therapeutic effect of mesenchymal stem cell transplantation in experimental autoimmune encephalomyelitis is mediated by peripheral and central mechanisms. Stem Cell Res Ther. 2012;3:3.

Muraro PA, Douek DC, Packer A et al. Thymic output generates a new and diverse TCR repertoire after autologous stem cell transplantation in multiple sclerosis patients. J Exp Med. 2005;201(5):805-16.

Nylander A, Hafler DA. Multiple sclerosis. J Clin Invest. 2012;122(4):1180-8.

Papadaki HA, Kritikos HD, Gemetzi C et al. Bone marrow progenitor cell reserve and function and stromal cell function are defective in rheumatoid arthritis: evidence for a tumor necrosis factor alpha-mediated effect. Blood. 2002; 99(5):1610-9.

Payne N, Siatskas C, Bernard CC. The promise of stem cell and regenerative therapies for multiple sclerosis. $J$ Autoimmun. 2008; 31(3):288-94.

Poser CM, Paty DW, Scheinberg L et al. New diagnostic criteria for multiple sclerosis: guidelines for research protocols. Ann Neurol. 1983;13(3):227-31.

Selmani Z, Naji A, Zidi I et al. HLA-G5 secretion by human mesenchymal stem cells is required to suppress Tlymphocyte and NK function and to induce CD4+CD25highFOXP3+ regulatory T cells. Stem Cells. 2007;26(1):212-22.

Steinman L. A molecular trio in relapse and remission in multiple sclerosis. Nat Rev Immunol. 2009;9(6):440-7.

Stys PK, Zamponi GW, Van Minnen J, Geurts JJG. Will the real multiple sclerosis please stand up? Nat Rev Neurosci. 2012; 13(7):507-14.

Sun LY, Zhang HY, Feng XB, Hou YY, Lu LW, Fan LM. Abnormality of bone marrow-derived mesenchymal stem cells in patients with systemic lupus erythematosus. Lupus. 2007;16(2):121-8.

Uccelli A, Moretta L, Pistoia V. Mesenchymal stem cells in health and disease. Nat Rev Immunol. 2008;8(9):72636 .

Uccelli A, Laroni A, Freedman MS. Mesenchymal stem cells as treatment for MS - progress to date. Mult Scler. 2012;Nov1.

Uccelli A, Prockop DJ. Why should mesenchymal stem cells (MSCs) cure autoimmune diseases? Curr Opin Immunol. 2010;22(6):768-74.

Virley DJ. Developing therapeutics for the treatment of multiple sclerosis. NeuroRx. 2005;2(4):638-49. 
Yamout B, Hourani R, Salti H et al. Bone marrow mesenchymal stem cell transplantation in patients with multiple sclerosis: a pilot study. J Neuroimmunol. 2010;227(1-2):185-9.

Zafranskaya MM, Nizheharodova DB, Yurkevich MY et al. In vitro assessment of mesenchymal stem cells immunosuppressive potential in multiple sclerosis patients. Immunol Lett. 2012;Oct 23.

Zappia E, Casazza S, Pedemonte E et al. Mesenchymal stem cells ameliorate experimental autoimmune encephalomyelitis inducing T-cell anergy. Blood. 2005;106:1755-61.

Zhang J, Li Y, Chen J et al. Human bone marrow stromal cell treatment improves neurological functional recovery in EAE mice. Exp. Neurol. 2005;195:16-26.

Zhang $\mathrm{J}, \mathrm{Li} \mathrm{Y}, \mathrm{Lu} \mathrm{M}$ et al. Bone marrow stromal cells reduce axonal loss in experimental autoimmune encephalomyelitis mice. J Neurosci Res. 2006;84:587-95.

\section{List of tables and figures:}

Table 1: Patients' demographic features, clinical laboratory parameters at onset (pre-transplantation) and at $\mathrm{D}+180$ post-autologous hematopoietic stem cell transplantation.

Figure 1: Characterization of multipotent mesenchymal stromal cells. A) Control MSCs exhibiting fibroblast-like morphology; B) Patient MSCs exhibiting fibroblast-like morphology; C) Expression of typical surface immunophenotypic markers; D) adipogenic and E) osteogenic differentiation potential.

Figure 2: Patient and control MSCs have distinct transcriptional profiles. A) Hiecharchical clustering analysis from gene expression data obtained from healthy MSCs and patient MSCs (preand post-transplantation). B) Differentially genes expressed in patient MSCs (pre-transplantation) compared to healthy MSCs.

Figure 3: Patient and control MSCs have distinct transcriptional profiles. A) Heatmap containing enriched genes, obtained from "Gene Set Enrichment Analysis", comparing patient MSCs (pretransplantation) with healthy MSCs. B-C) FGF and HGF sinaling pathways, obtained from "Ingenuity Pathway Analysis", containing repressed and induced genes in patient MSCs (pre-transplantation).

Figure 4: Patient MSCs have decreased ability to inhibit T-cell proliferation. A) Percentages of lymphocyte proliferation in cocultures with healthy MSCs. B-C) Percentages of lymphocyte proliferation in cocultures with patient MSCs (pre- and post-transplantation). D) Inhibitory activity of patients (pre- and post-transplantation) and healthy MSCs in cocultures with allogeneic lymphocytes.

Table 2: Regulatory lymphocytes subpopulations recovered after cocultures with healthy and patient MSCs (pre- and post-transplantation).

Figure 5: Patient MSCs have decreased anti-inflammatory cytokine secretion. Concentration $(\mathrm{pg} / \mathrm{mL})$ of pro-inflammatory (IFN- $\gamma, \mathrm{TNF}, \mathrm{IL}-1 \beta$, and IL-6) and anti-inflammatory cytokines (IL-10 and TGF- $\beta$ ), HGF and chemokine CXCL-10 in supernatants from cocultures with patient MSCs (pre- and post-transplantation) and healthy MSCs. 
Table 1

\begin{tabular}{|c|c|c|c|c|c|}
\hline Patients & $\begin{array}{c}\text { Genderl } \\
\text { age (years) }\end{array}$ & MS & $\begin{array}{c}\text { Disease } \\
\text { duration } \\
\text { (years) }\end{array}$ & $\begin{array}{c}\text { EDSS } \\
\text { pre/post- } \\
\text { AHSCT }\end{array}$ & $\begin{array}{c}\text { RMN } \\
\text { pre/post- } \\
\text { AHSCT } \\
\end{array}$ \\
\hline EM01 & $\bar{F} / 43$ & PS & 16 & $6.5 / 6.5$ & $\overline{G d}-/ G d-$ \\
\hline EM02 & $\mathrm{M} / 49$ & PP & 17 & $6.5 / 6.5$ & Gd-/Gd- \\
\hline EM03 & $\mathrm{F} / 31$ & PS & 12 & $6.5 / 5.5$ & $\mathrm{Gd}+/ \mathrm{Gd}-$ \\
\hline EM04 & $\mathrm{F} / 42$ & PS & 12 & $6.5 / 6.0$ & $\mathrm{Gd}+/ \mathrm{Gd}-$ \\
\hline EM05 & $\mathrm{M} / 49$ & $\mathrm{RR}$ & 20 & $3.0 / 4.5$ & Gd-/Gd- \\
\hline EM06 & $\mathrm{F} / 32$ & PS & 13 & $6.0 / 6.0$ & Gd-/Gd- \\
\hline EM07 & $\mathrm{M} / 49$ & $\mathrm{RR}$ & 11 & $4.0 / 4.0$ & Gd-/Gd- \\
\hline EM08 & $\mathrm{F} / 41$ & PS & 16 & $6.5 / 6.5$ & Gd-/Gd- \\
\hline EM09 & $\mathrm{M} / 43$ & PS & 9 & $6.0 / 4.5$ & Gd-/Gd- \\
\hline EM10 & $\mathrm{M} / 45$ & PS & 15 & $5.5 / 5.0$ & Gd-/Gd- \\
\hline EM11 & $\mathrm{F} / 41$ & RR & 8 & $3.0 / 3.0$ & Gd-/Gd- \\
\hline EM12 & $\mathrm{F} / 20$ & PS & 13 & $5.5 / 3.5$ & Gd-/Gd- \\
\hline EM13 & $\mathrm{F} / 24$ & PS & 9 & $7.0 / 7.5$ & Gd-/Gd- \\
\hline EM14 & $\mathrm{F} / 30$ & PS & 9 & $5.5 / 4.5$ & Gd-/Gd+ \\
\hline EM15 & $\mathrm{F} / 30$ & PS & 19 & $6.0 / 6.0$ & $\mathrm{Gd}+/ \mathrm{Gd}-$ \\
\hline EM16 & $\mathrm{F} / 43$ & PS & 7 & 6.5/ND & Gd-/ND \\
\hline EM17 & $\mathrm{M} / 27$ & RR & 6 & $4.0 / 4.0$ & $\mathrm{Gd}+/ \mathrm{Gd}-$ \\
\hline EM18 & $\mathrm{F} / 48$ & PS & 12 & $5.0 / 5.5$ & Gd-/Gd- \\
\hline EM19 & $\mathrm{M} / 39$ & PP & 4 & $4.0 / 4.0$ & Gd-/Gd- \\
\hline
\end{tabular}


Figure 1.
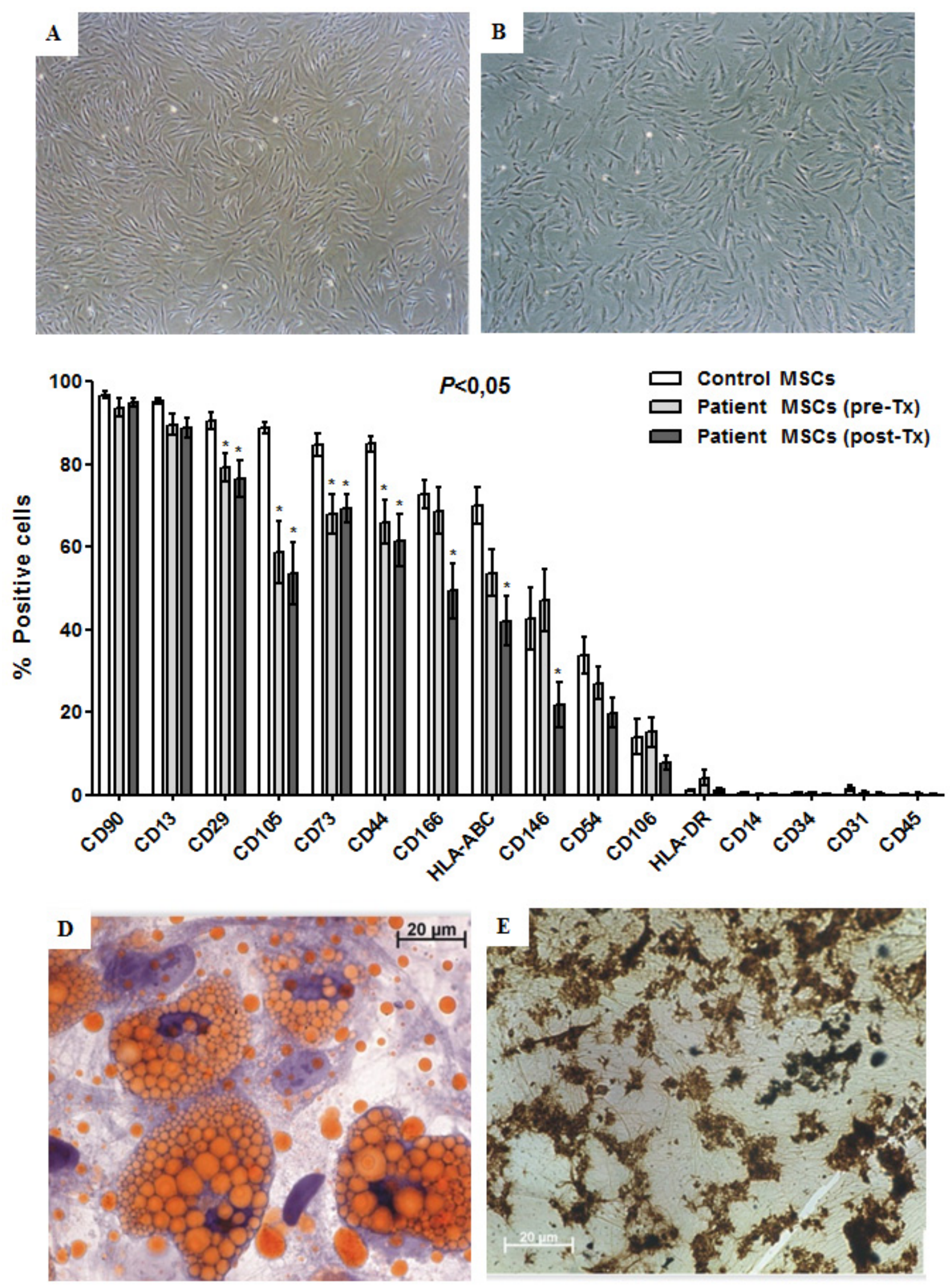
Figure 2.
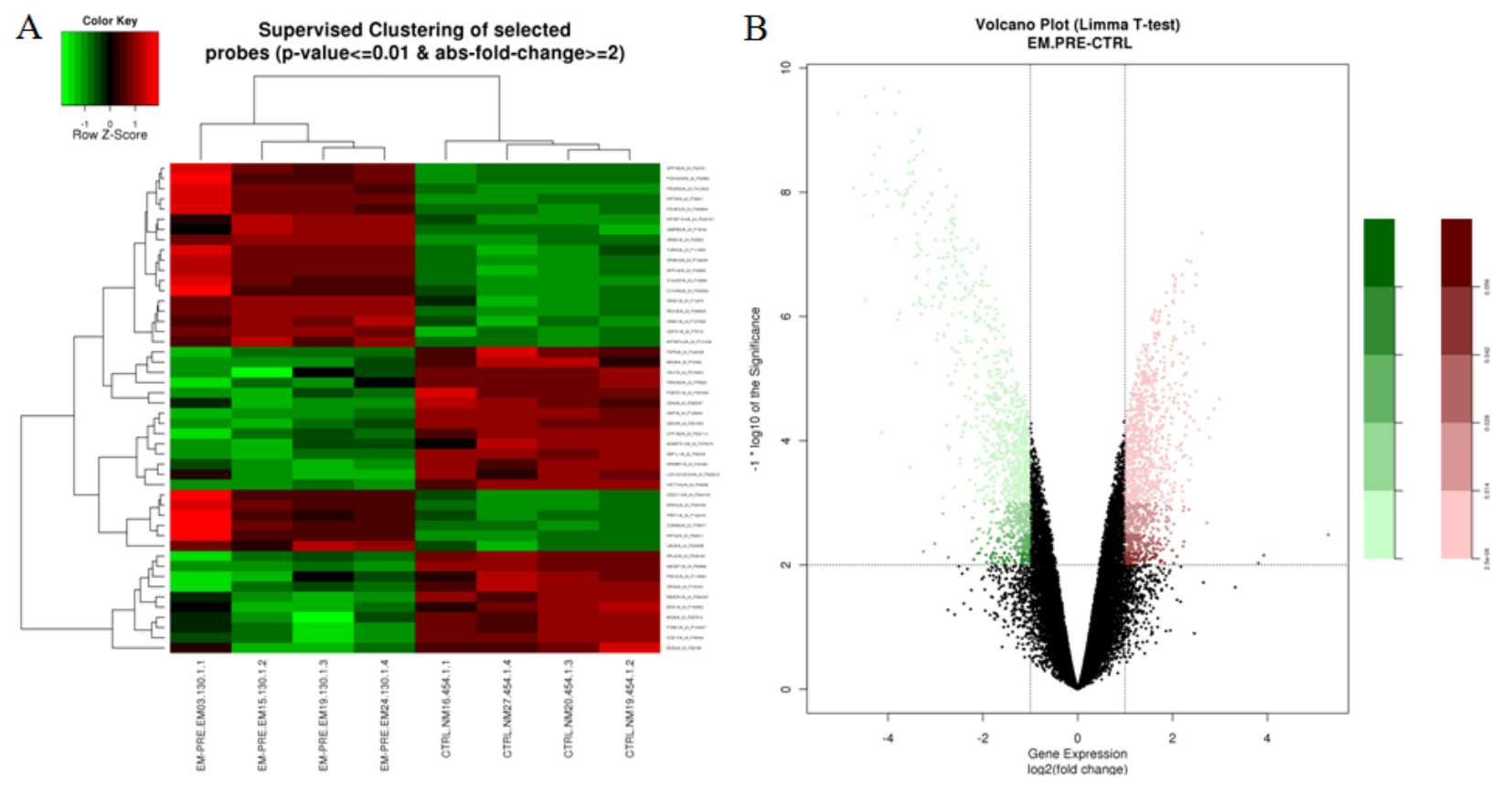
Figure 3.

A) Cytokine-cytokine receptor interactions

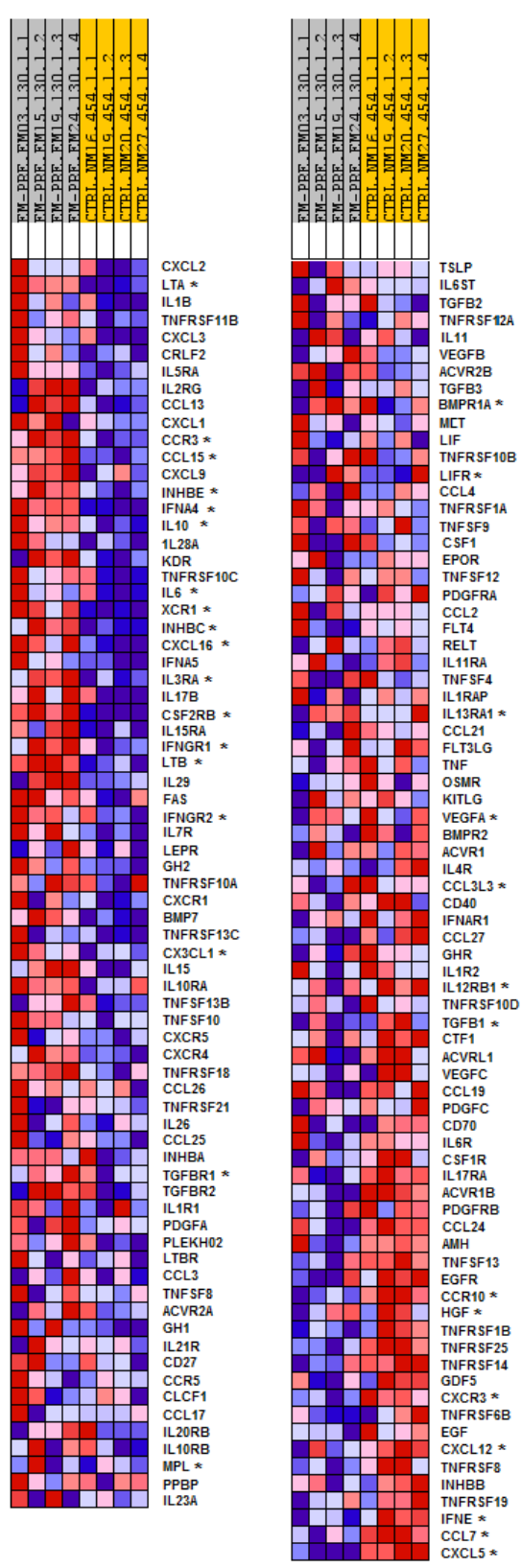

B) FGF Signaling

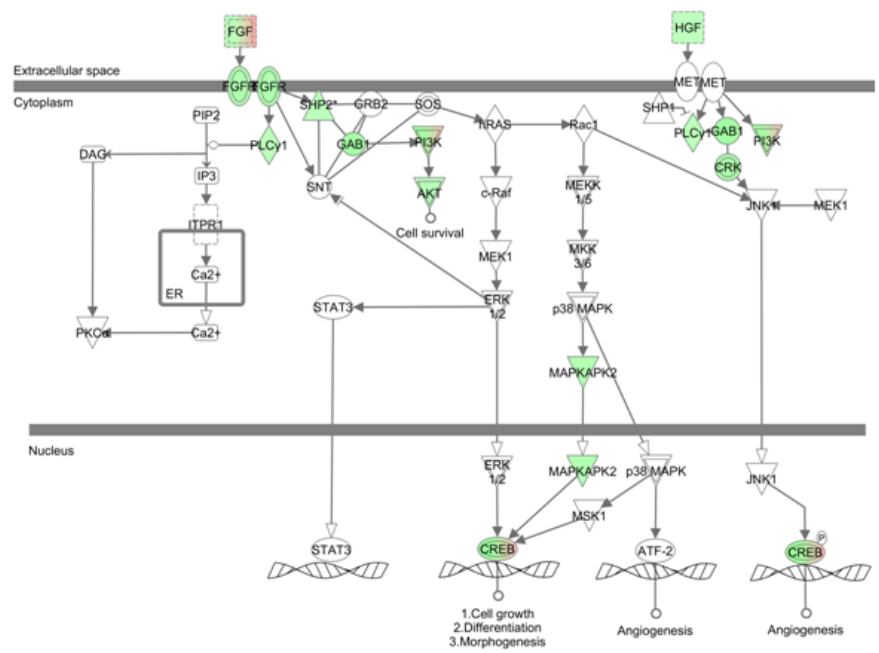

C)

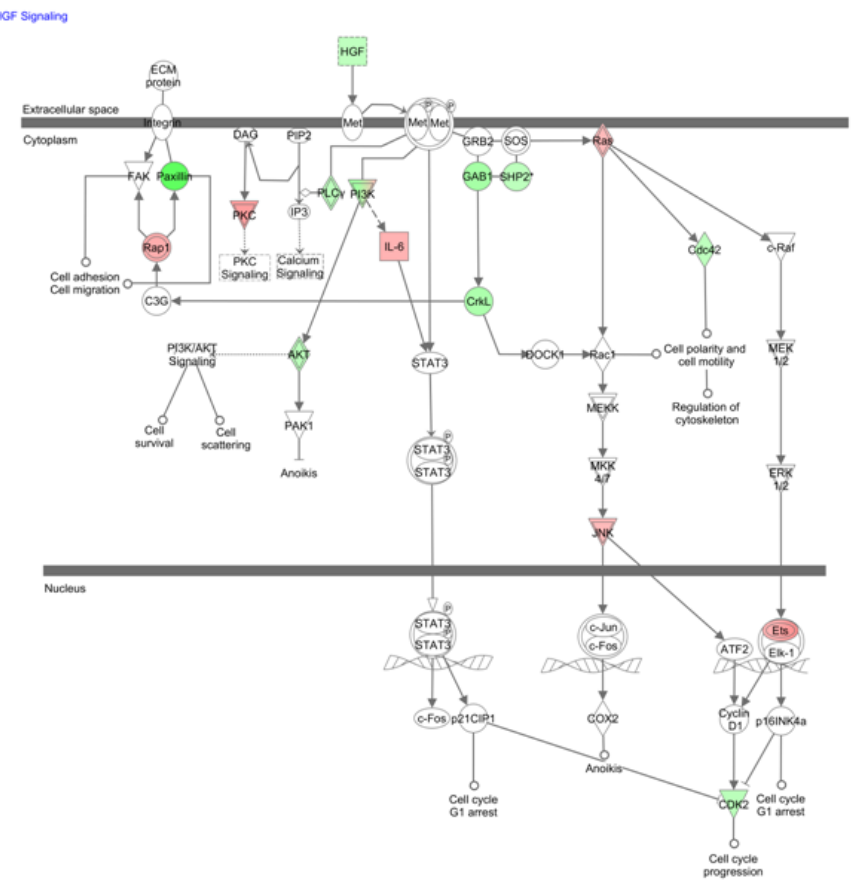


Figure 4.
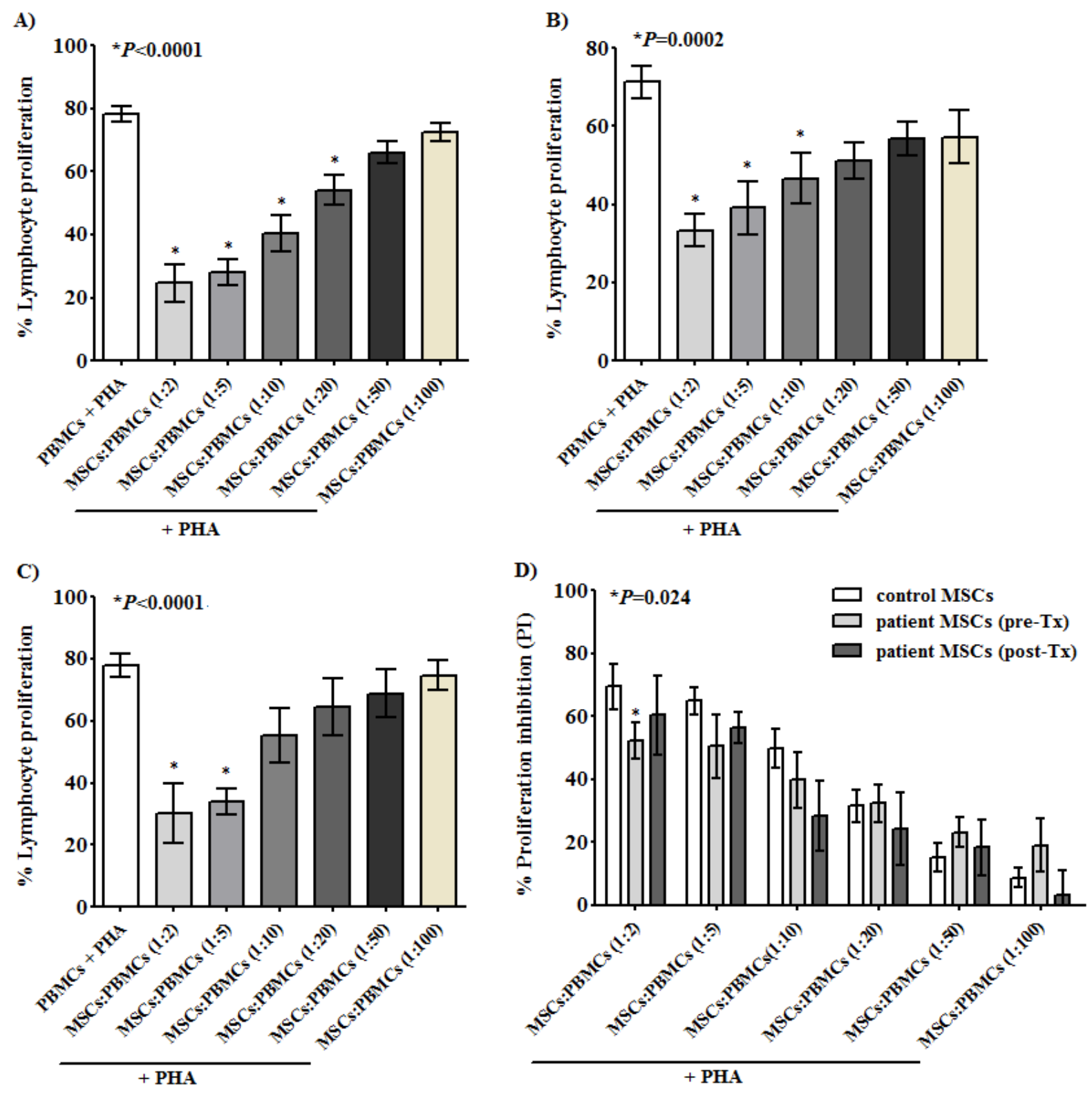
Table 2

\begin{tabular}{|c|c|c|c|c|}
\hline Regulatory subsets & $\begin{array}{l}\text { PBMCs } \\
+ \text { PHA }\end{array}$ & $\begin{array}{l}\text { Control } \\
\text { MSCs }\end{array}$ & $\begin{array}{c}\text { Patient MSCs } \\
\text { Pre-Tx }\end{array}$ & $\begin{array}{c}\text { Patient MSCs } \\
\text { Post-Tx }\end{array}$ \\
\hline T CD4 $^{+}$CD25 ${ }^{\text {hi }}$ Foxp3 $^{+}$ & & $0.59 \pm 0.25 \%$ & $2.57 \pm 0.98 \%$ & $1.42 \pm 0.58 \%$ \\
\hline $\mathrm{T} \mathrm{CD}^{+} \mathrm{CD} 25^{\mathrm{hi}} \mathrm{CTLA}-4^{+}$ & & $2.50 \pm 0.66 \%$ & $3.48 \pm 1.56 \%$ & $3.35 \pm 1.78 \%$ \\
\hline $\mathrm{T} \mathrm{CD}^{+}{ }^{+} \mathrm{CD} 25^{\mathrm{hi}} \mathrm{GITR}^{+}$ & & $9.35 \pm 2.73 \%$ & $13.9 \pm 3.70 \%$ & $17.1 \pm 5.75 \%$ \\
\hline T CD8 ${ }^{+}$CD28-Foxp3+ & & $0.39 \pm 0.37 \%$ & $1.78 \pm 1.70 \%$ & $0.11 \pm 0.06 \%$ \\
\hline $\mathrm{T} \mathrm{CD}^{+} \mathrm{HLA}-\mathrm{G}^{+}$ & & $3.71 \pm 1.79 \%$ & $2.88 \pm 0.70 \%$ & $2.92 \pm 1.30 \%$ \\
\hline T CD8 $^{+}$HLA-G $^{+}$ & & $2.42 \pm 0.74 \%$ & $2.03 \pm 0.48 \%$ & $1.50 \pm 0.41 \%$ \\
\hline $\mathrm{T} \mathrm{CD}^{+} \mathrm{NKT}^{+}$ & & $4.36 \pm 1.89 \%$ & $2.73 \pm 0.48 \%$ & $2.98 \pm 1.34 \%$ \\
\hline
\end{tabular}

Figure 5.

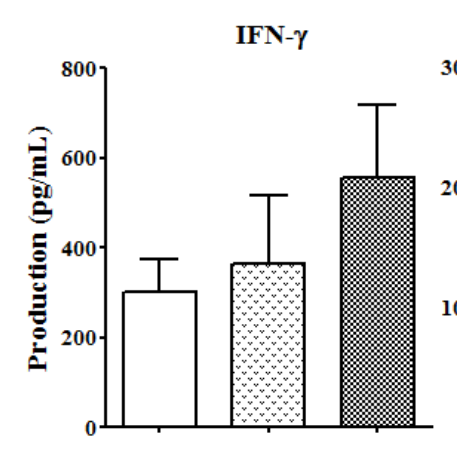

IL-10

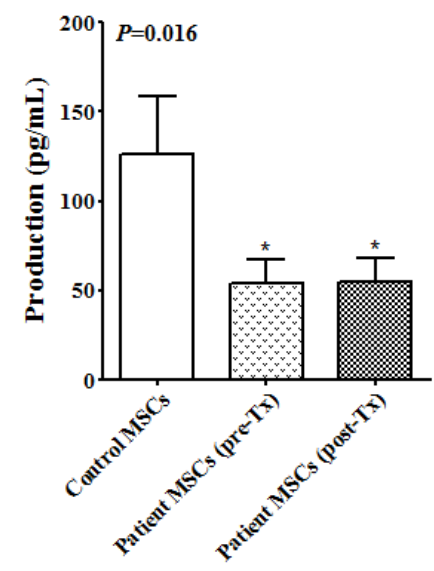

TNF- $\alpha$

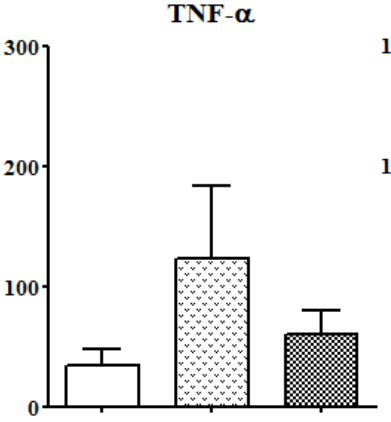

TGF- $\beta$

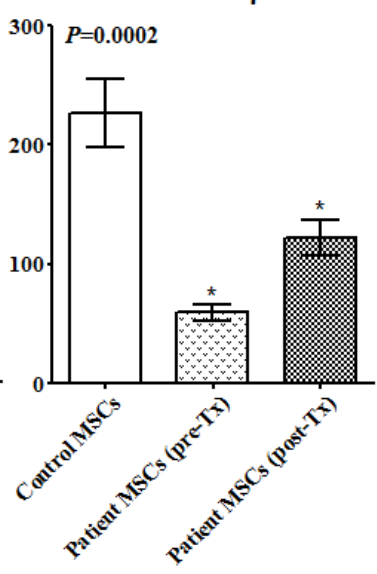

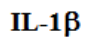

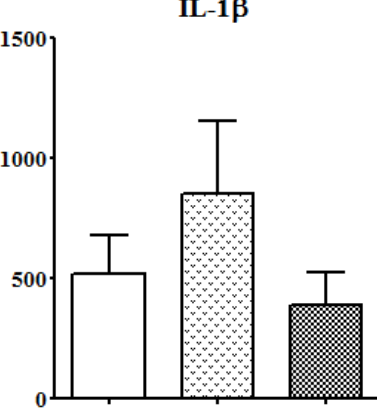

HGF

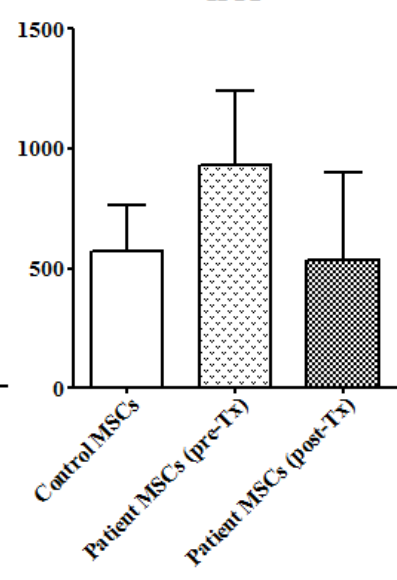

IL-6

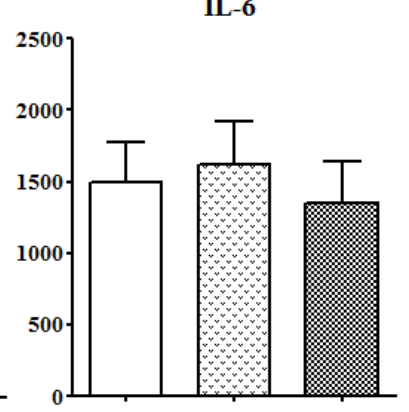

CXCL-10

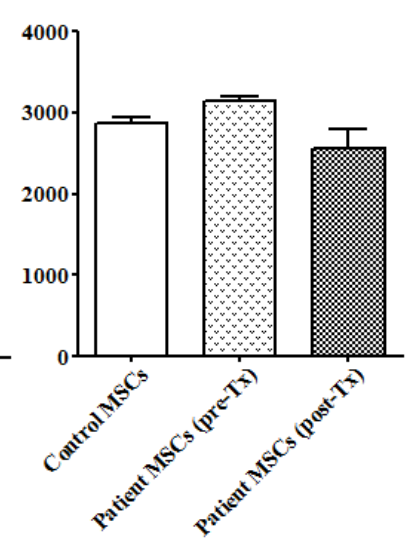

